\title{
Z POSLUCHÁRNY ZA KATEDRU \\ Mocenské vztahy ve výuce studentů učitelství
}

\author{
Kateřina Vlčková \\ Kateřina Lojdová \\ Josef Lukas \\ Jan Mareš \\ Zuzana Šalamounová \\ Tomáš Kohoutek \\ Jarmila Bradová \\ Stanislav Ježek
}

Masarykova univerzita

Brno 2015 


\section{KATALOGIZACE V KNIZE - NÁRODNÍ KNIHOVNA ČR}

Vlčková, Kateřina

Z posluchárny za katedru : mocenské vztahy ve výuce studentů učitelství / Kateřina Vlčková, Kateřina Lojdová, Josef Lukas, Jan Mareš, Zuzana Šalamounová, Tomáš Kohoutek, Jarmila Bradová, Stanislav Ježek. -- 1. vydání. -- Brno : Masarykova univerzita, 2015. -- 238 stran

ISBN 978-80-210-8096-6

$378.011 .3-052$ * 377 * $371.12 / .16$ * 371.133 * $316.772 .4: 37$ * 316.462 * 37 * $303.022 *(437.3)$

- vysokoškolští studenti

- profesní prríprava

- učitelská profese

- pedagogická praxe

- pedagogická komunikace

- moc -- pedagogické aspekty

- autorita -- pedagogické aspekty

- kvalitativní výzkum -- Česko

- kolektivní monografie

371 - Školství (organizace) [22]

Autoři kapitol:

Kateřina Vlčková (kap. 2.6.2, 3, 4.1, 4.4, př́lohy, resumé, summary)

Kateřina Lojdová (kap. 2, 4.1, 4.2, 4.3, 5, úvod, závěr, resumé, rejstř́ík)

Josef Lukas (kap. 1, 4.3, 5)

Jan Mareš (kap. 1, 4.6)

Zuzana Šalamounová (kap. 2, 3, 4.5)

Tomáš Kohoutek (kap. 2.6.5, 4.6, 5)

Jarmila Bradová (kap. 2)

Stanislav Ježek (kap. 4.1)

Recenzenti

prof. PhDr. Jiří Mareš, CSc., Ústav sociálního lékařství Lékařské fakulty Univerzity Karlovy v Hradci Králové

doc. Mgr. Klára Šedová, Ph.D., Ústav pedagogických věd Filozofické fakulty Masarykovy univerzity

(c) 2015 Masarykova univerzita

(C) 2015 Kateřina Vlčková, Kateřina Lojdová, Josef Lukas, Jan Mareš, Zuzana Šalamounová, Tomáš Kohoutek, Jarmila Bradová, Stanislav Ježek

ISBN 978-80-210-8096-6

ISBN 978-80-210-8097-3 (online : pdf) 
Publikace vznikla v rámci projektu Grantové agentury České republiky GA13-24456S s názvem Moc ve školních třídách studentư učitelství řešeného na Katedře pedagogiky Pedagogické fakulty Masarykovy univerzity. Autoři děkují za poskytnutou podporu, díky níž se mohli tomuto tématu delší dobu věnovat. Poděkování patří také recenzentům, prof. Jiř́mu Marešovi a doc. Kláře Šedové, kteř́ svými kritickými a velmi podnětnými posudky přispěli $k$ finální podobě této knihy. Velké poděkování náleží samotným studentům učitelství: Alici, Karle, Lence, Mileně, Petře, Radkovi, Věre a Zdeně, kteří byli natolik stateční, že nás nechali sledovat jejich cestu z posluchárny za katedru. 



\section{OBSAH}

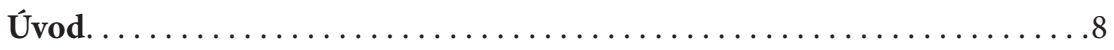

1 Cesta od studenta učitelství k začínajícímu učiteli .............11

1.1 Vynořující se dospělost - pohled na vývojovou fázi studentů učitelství ..............................

1.2 Raný profesní vývoj učitele...........................

1.2.1 Možné pohledy na vývoj studentů učitelství $\ldots \ldots \ldots \ldots \ldots \ldots 16$

1.2.2 Vývoj identity: tenze a dilemata $\mathrm{v}$ přechodech $\mathrm{z}$ role studenta

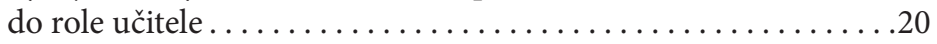

2 Fenomén moci a jeho souvislost se školním prostředím ...........22

2.1 Moc v sociálních vědách . . . . . . . . . . . . . . . . . . 22

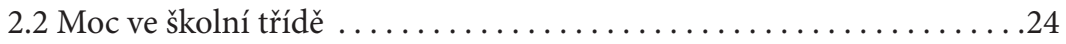

2.2.1 Vstup do třídy a pojetí moci u začínajících učitelů..........26

2.3 Moc za hranicemi školní třídy . . . . . . . . . . . . . . . . 28

2.4 Koncept moci v českém pedagogickém prostředí...............30

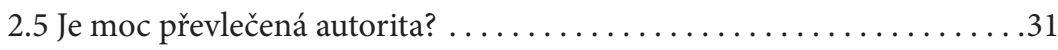

2.5.1 Cirkularita moci .............................. 33

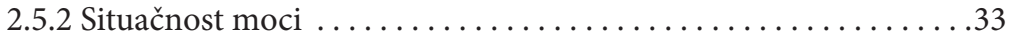

2.5.3 Reciprocita moci.................................

2.5.4 Moc jako téma výzkumu ....................... 35

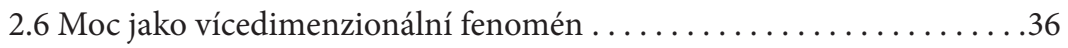

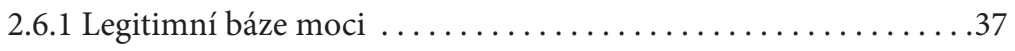

2.6.2 Donucovací báze moci..............................

2.6.3 Odměňovací báze moci......................41

2.6.4 Expertní báze moci $\ldots \ldots \ldots \ldots \ldots \ldots \ldots \ldots \ldots \ldots \ldots \ldots . \ldots \ldots 2$

2.6.5 Referenční báze moci..........................44

2.6.6 Vývoj konceptu bází moci......................45

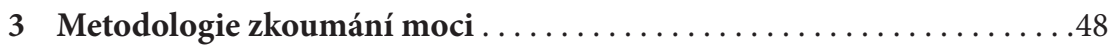

3.1 Cíl výzkumu a výzkumné otázky.....................48

3.2 Smíšený design výzkumu $\ldots \ldots \ldots \ldots \ldots \ldots \ldots \ldots \ldots \ldots \ldots \ldots$

3.3 Výzkumný vzorek ............................49 


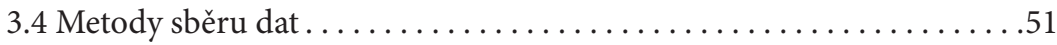

3.4.1 Pozorování. ................................ 51

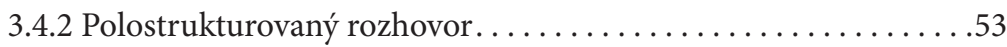

3.4.3 Reflektivní deník ...........................54

3.4.4 Dotazník „Báze moci: verze pro studenty učitelstvi“ . .........54

3.4 .5 Fáze sběru dat ............................... 57

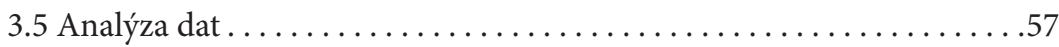

4. Výsledky výzkumu: identifikované projevy bází moci u studentů učitelství . . . . . . . . . . . . . . . . . . . . . . .59

4.1 Báze moci studentů učitelství na praxi aneb Jak to vidí žáci . ........60

4.2 Legitimní báze moci aneb Vypůjčená moc studenta učitelství . . . . . . .66

4.2.1 Propůjčení legitimní moci studentovi učitelství ............69

4.2.2 Legitimní moc v interakci studenta učitelství

a cvičného učitele...........................76

4.2.3 Shrnutí: Neviditelná legitimní moc, bez které to však nejde . . . .80

4.3 Donucovací báze moci aneb Dobrý učitel má vše pevně v rukou. . . . . 882

4.3.1 Donucovací moc ve školním kontextu $\ldots \ldots \ldots \ldots \ldots \ldots \ldots 82$

4.3.2 Projevy donucovací moci a jejich typologie...............84

4.3.3 Donucovací moc v IRF komunikační struktuře . . . . . . . . . 85

4.3.4 Miniscénáře donucovací moci ..................92

4.3.5 Shrnutí: Význam donucovací moci ve třídách začínajících

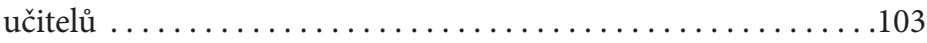

4.4 Odměňovací báze moci aneb Dobrý učitel žáky odměňuje. .........105

4.4.1 Podoby odměňovací moci studenta učitelství na praxi ........108

4.4.2 Odměňovací moc studenta učitelství $\mathrm{z}$ pohledu

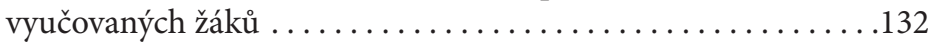

4.4.3 Shrnutí: Žák je odměňován, když hraje svoji roli žáka správně. .135

4.5 Expertní báze moci aneb Dobrý učitel jako mistr svého řemesla.....138

4.5.1 Přiznané expertství v modu kooperace...............138

4.5.2 Tušené expertství v modu kompromisu .................144

4.5.3 Zpochybněné expertství v modu kompetice ...............147

4.5.4 Shrnutí: Experti? Zatím ještě ne.....................155 
4.6 Referenční báze moci aneb Dobrý učitel jako dobrý člověk . . . . . . .157

4.6.1 Podoby referenční moci ........................ 157

4.6.2 Operacionalizace a výsledky kvantitativní povahy ...........160

4.6.3 Souvislosti s dalšími bázemi moci ...................162

4.6.4 Kvalitativní zdroje - záznamy a výpovědi v rámci rozhovorů . . 166

4.6.5 Studující - učitel jako komunikační partner žáků. ............166

4.6.6 Shrnutí: Referenční moc jako intuitivní báze moci? ..........176

\section{K diskusi: První zkušenosti studentů učitelství se samostatnou}

výukou....................................

5.1 První zkušenosti studentů učitelství se samostatnou výukou

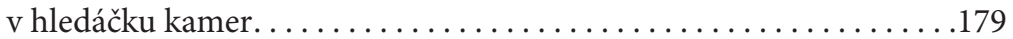

5.2 První zkušenosti studentů učitelství se samostatnou výukou v kontextu vývojové fáze a sociální role ...................181

Závěrem aneb Rituály moci a moc rituálů. . . . . . . . . . . . . . 184

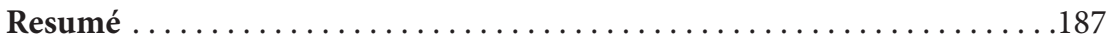

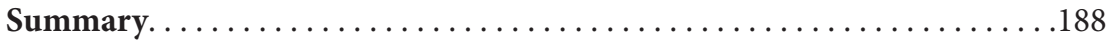

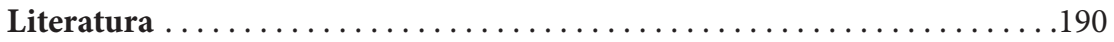

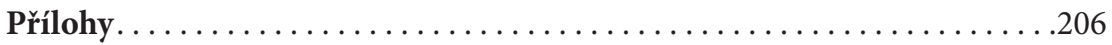

Př́loha 1. Dotazník Báze moci: verze pro studenty učitelství . . ....... 206

Př́loha 2. Dotazník Báze moci: verze pro učitele ..............210

Př́loha 3. Tazatelské schéma polostrukturovaného rozhovoru.........212

Př́loha 4. Manuál pro transkripci videodat a audiodat ............214

Př́loha 5. Ukázka transkriptu videozáznamu výuky ..............217

Př́loha 6. Ukázka transkriptu rozhovoru..................222

Př́loha 7. Pokyny pro studenty učitelství k reflektivnímu deníku ......227

Př́loha 8. Ukázka z reflektivního deníku .....................229

Seznam použitých grafů a obrázků. ....................... 231

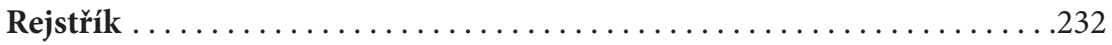




\title{
ÚVOD
}

\begin{abstract}
"Já vím, že se nedá všechno jakoby na fakultě naučit, že člověk to získá praxí. Jako jakoby tu didaktiku tam se ještě néco stihne probrat. Ale to řízeni třídy, to ne, to je prostě, vỉbec, to ažživot" (Zdena).
\end{abstract}

Studentka učitelství Zdena zde hovoří o svých prvních zkušenostech z výuky na druhém stupni základní školy, které se odehrály v rámci její praxe. Stejně jako mnoho jiných studentů učitelství pojmenovala Zdena největší výzvu, která na studenta učitelství ve chvíli, kdy se poprvé ocitá za katedrou v roli učitele, čeká - „uřídit tř́ídu“. Schopnost učitele vnímat momentální naladění jednotlivých žáků i aktuální atmosféru školní třídy a podle toho přizpůsobovat práci ve výuce a její organizaci je přitom nezbytným předpokladem $\mathrm{k}$ naplňování didaktických cílů, tedy k tomu, aby učitel mohl ve tř́dě vůbec vyučovat. $Z$ tohoto důvodu jsme se $\mathrm{v}$ rámci našeho výzkumu rozhodli zaměřit pozornost na fenomén moci ve školní třídě. Moc lze charakterizovat jako potenciál ovlivňovat postoje a jednání druhých osob, takže do značné míry představuje jádrovou oblast výukového procesu. Zároveň je fenomén moci reciproční, což znamená, že mocí učitel disponuje jen tehdy, pokud mu ji žáci skutečně připisují. Moc tedy odpovídá interakčnímu charakteru výukového procesu a skrze ni můžeme porozumět tomu, co se mezi učiteli a žáky ve školní tř́dě odehrává. V našem výzkumu jsme se tedy zaměřili na to, jak studenti učitelství, kteří v rámci své učitelské praxe garantované pedagogickou fakultou získávají první zkušenosti z vlastní výuky na druhém stupni českých základních škol, a to právě s ohledem na uspořádání mocenských vztahů v jejich tř́íách.

Studenti učitelství se nacházejí ve specifickém vývojové etapě z hlediska ontogenetického i profesního vývoje, proto knihu otevíráme rámcovým popisem období tzv. vynořující se dospělosti, kterou lze vymezit dvacátým až třicátým rokem života člověka. Z hlediska profesního vývoje chápeme studium jako součást počátečního období vývoje učitele, protože problémy studenta učitelství a začínajícího učitele jsou do značné míry obdobné. Charakteristika začínajícího učitele (studenta učitelství) předjímá pojednání o pojetí moci. Moc totiž není charakteristikou samou o sobě, ale vždy se váže na určité aktéry sociální reality.

Uchopit komplexní fenomén moci jsme se pokusili skrze smíšený výzkumným design. Položili jsme si základní výzkumnou otázku: Jak probíhá proces vyjednávání moci mezi studenty učitelství a jejich žáky ve vyučování na druhém stupni české základní školy v prüběhu dlouhodobé pedagogické praxe? Kvalitativní část našeho výzkumu byla postavena na analýze videozáznamů výuky osmi 
studentů učitelství v průběhu jednoho semestru, na následných polostrukturovaných rozhovorech s těmito studenty a také na denících, které si tito studenti učitelství psali v průběhu praxe. Kvantitativní data vnáší do studie výsledky dotazníku Báze moci pro žáky distribuovaného $\mathrm{v}$ osmi třídách studentů učitelství $\mathrm{z}$ našeho výzkumného vzorku.

Studenti učitelství, kteří se zúčastnili našeho výzkumu, tedy postupně přecházejí z posluchárny za katedru. Součástí tohoto přechodu jsou příběhy prvních zkušeností s uspořádáním i uplatňováním moci ve školní tř́iě. Interpretaci výsledků vedeme skrze jednotlivé složky moci, které označujeme jako báze. Přestože se jednotlivé báze moci v realitě překrývají, ve výsledkové lince jsou popsány odděleně s odkazy na vzájemné př̌kryvy. Nejprve popisujeme moc legitimní, jež je ilustrována na vstupu studenta učitelství do nové role učitele. S legitimní mocí úzce souvisí moc donucovací, nebot donucování předpokládá legitimitu toho, kdo donucuje. Na donucování nahlížíme skrze jeho typické projevy ve školní třídě, které lze popsat pomocí relativně ustálených struktur komunikace označených jako miniscénáře. Určitým protikladem $\mathrm{k}$ donucování je moc odměňovací, jejíž projevy tvoří druhou stranu stejné mince. Ukazujeme podoby odměňovací moci a situace odměňování, které mohou být neočekávané i pro studenty učitelství. Moc postavenou na didaktických dovednostech a odborných znalostech odkrývá kapitola věnovaná expertní moci. Empirické kapitoly završuje kapitola o moci referenční, jež je postavena na vztahu studenta učitelství se žáky. Navázáním vztahu se žáky, které je dlouhodobým úkolem pro budoucí učitele, naši analýzu př́iběhů moci uzavíráme. Výsledky našeho výzkumu diskutujeme v metodologických i teoretických souvislostech a knihu netradičně uzavíráme rozšiřujícím konceptem rituálů moci.

Tato monografie je určena především odborníkům připravujícím budoucí učitele: pedagogům, psychologům, oborovým didaktikům a všem vysokoškolským učitelům podílejícím se na pregraduální přípravě učitelů. Dalšími adresáty jsou cviční učitelé, kteří se připravují na vedení studentů učitelství na praxi v kurzech celoživotního vzdělávání nebo již studenty na praxi vedou. V neposlední řadě může být publikace inspirativní pro učitele v praxi a pochopitelně i pro studenty učitelství. Všem zmíněným adresátům se v naší publikaci snažíme poukázat na dilemata, rozpory a nejistoty, se kterými se (budoucí) učitel bude potýkat, nebở neexistují obecně účinné metody a soubory technik ke zvládání komplexity, nejistoty a problematičnosti učitelského povolání (srov. Štech, 1994).

Přestože čtenáři nabízíme určitou obsahovou linku našeho výzkumu (který je vlastně prríběhem objevování souvislostí zkoumaného fenoménu), chceme zdůraznit, že charakter knihy je modulární, a cesta čtenáře knihou proto nemusí být nutně lineární. Jednotlivé kapitoly je tedy možné procházet dle individuálních a aktuálních preferencí čtenáře. Stejně tak jako může být pro někoho př́nosné 
ÚVOD

začít četbu vývojovým obdobím studentů učitelství, pro jiného se stane vhodným vstupem pojednání o fenoménu moci. Taktéž je možné se začíst do výsledků výzkumu a poté se vracet $k$ teorii. Nabízíme tedy čtenářům, aby volně přecházeli v knize dle svých potřeb a nebáli se přistoupit kdykoliv k monty pythonovskému pojetí: „a nyní z úplně jiného soudku“.

Výzkumný tým z Katedry pedagogiky a z Katedry psychologie Pedagogické fakulty Masarykovy univerzity 


\section{CESTA OD STUDENTA UČITELSTVÍ K ZAČÍNAJÍCÍMU UČITELI}

Josef Lukas, Jan Mareš

Než se budeme věnovat vymezení hlavního konceptu předkládané monografie, tedy moci učitele ve třídě a následnému zkoumání tohoto fenoménu $\mathrm{v}$ kontextu pregraduální př́ípravy učitelů, považujeme za důležité zmínit téma vývoje učitele. V této kapitole ${ }^{1}$ se pokusíme zasadit raný vývoj učitele, at již studenta učitelství či začínajícího učitele, do širšího rámce psychologicky pojímaného vývoje identity jedince, protože jak někteři autoři naznačují, právě psychologický pohled na tuto problematiku ve většině vědeckých pojednání, věnovaných profesní identitě učitele, doposud nebyl príliš akcentován (srov. Friesen \& Besley, 2013). Při komplexnějším pohledu na profesní vývoj jedince $\mathrm{z}$ hlediska psychologie zjištujeme, že je třeba pracovat nejen $s$ náměty z vývojové psychologie a sociální psychologie, ale i z psychologie osobnosti, protože dle některých výzkumů dochází především u mladých dospělých ke změnám osobnostních rysů pod vlivem pracovních zkušeností (Roberts, Caspi, \& Moffit, 2003).

\subsection{Vynořující se dospělost - pohled na vývojovou fázi studentů učitelství}

Tradiční pohled na studenty učitelství ve čtvrtém ročníku je typický pro profesní studia a předpokládá vysokou míru zaujetí a přijímání závazků v profesní oblasti (srov. Macek et al., 2016). To ne zcela odpovídá dostupným datům (Koucký, Ryška, \& Zelenka, 2014) i zkušenostem vyučujících pedagogických fakult. Studující tak vykazují nižší míru profesní identifikace i další charakteristiky historicky připisované spíše předcházející životní etapě - adolescenci (srov. Macek, 2003). Konstruktem, který umožňuje tento fenomén popsat komplexním způsobem, s ohledem na psychologické, demografické i sociální trendy, je koncept vynořující se dospělosti (emerging adulthood).

Vývojová etapa mezi dvacátým a třicátým rokem života je obdobím významných změn a lidé jej subjektivně vnímají jako zlomové (Arnett, 2000). Období dospívání je v současné době delší a je pro něj charakteristické experimentování s možnými směry dalšího vývoje (Arnett, 2000). Některé charakteristiky a hodnoty, které byly tradičně vztahovány spíše k období adolescence - sebeobjevování,

1 Naše monografie se jako celek snaží integrovat poznatky pedagogické psychologie a pedagogiky, proto i tato kapitola bude vycházet ze zjištění těchto dvou vědeckých disciplín. Interdisciplinaritu ve vědeckém zkoumání reality (v našem př́ípadě fenoménů vývoje učitele a ustavování moci studentů učitelství) považujeme za zásadní směr, který umožňuje poskytnout komplexnější pohled na zkoumanou problematiku. 
experimentování, orientace na zábavu a další - zůstaly přitažlivé i pro lidi ve věku od dvaceti do třiceti let (Macek, 2005). Toto prodloužené a specifické stadium přechodu do dospělosti v rozvinutých zemích označil J. J. Arnett v roce 1998 jako vynořující se dospělost (emerging adulthood).

Vynořující se dospělost Arnett popisuje jako období mezi okamžikem, kdy mladí lidé obvykle opouštějí střední školu a chvílí, kdy začnou sami sebe považovat za naprosto dospělé (Arnett \& Taber, 1994). Arnett tuto etapu zařadil mezi 18. až 25. rok života jedince, přičemž konkrétní hranice se mohou měnit podle individuálních charakteristik jedince (Arnett, 2000, 2004). Období vynořující se dospělosti bývá obvykle zakončeno okolo třicátého roku věku. To už se většina dotazovaných považovala za plně dospělé (Arnett, 2000). Vynořující se dospělost je fenoménem, který můžeme pozorovat především v západních zemích a vyspělých společnostech. Macek, Bejček a Vaníčková (2007) ve svém výzkumu tento fenomén prokázali i u mladých lidí v České republice, i když konstatují přetrvávání některých kulturních rozdílů mezi Českem a zeměmi, jež do výzkumu zahrnul Arnett (2000).

Podle Arnetta (2004) lze vynořující se dospělost popsat pěti charakteristikami - hledáním identity, nestabilitou, zaměřením se na sebe, pocitem „mezi“ (ani adolescent, ani dospělý) a šíŕi možností, ze kterých si mohou vynořující se dospělí vybírat. Především pocit „mezi“ je základní psychologickou charakteristikou vynořující se dospělosti. Jak ukazují předchozí výzkumy, na otázku, zda se cítí být dospělými, odpovídá většina dotázaných, že v některých aspektech ano, ale v jiných nikoliv (Arnett, 2004; Macek et al., 2007).

Macek a kol. (2007) tento pocit „mezi“ charakterizují jako subjektivní vývojový status (subjective developmental status). Jedná se vlastně o to, kam se na škále „dospívající - ani dospělý, ani dospívající - dospělý“ mladý člověk sám zařadí. Tento subjektivní vývojový status tak může mít v daném období pro konkrétní osobu tři základní podoby - adolescentní status, prrechodový status (typický pro vynořující se dospělost) a dospělý status. Jedná se tedy o jedno z hlavních kritérií, i když ne o jediné, podle kterého můžeme rozpoznat, zda se konkrétní člověk aktuálně nachází v období vynořující se dospělosti (Arnett, 2000, 2004). Subjektivní vývojový status podle výzkumných zjištění (např. Arnett, 2000, 2004; Macek et al., 2016) ovlivňují jednak demografické podmínky - jestli je člověk student nebo pracující, bydlí s rodiči, sám nebo s přáteli, míra finanční nezávislosti apod. Rozdíl byl objeven také mezi lidmi v manželství a svobodnými nebo lidmi, kteří mají děti (Macek et al., 2007). Svou roli hraje také aktuální emocionální rozpoložení (Macek et al., 2016).

V souvislosti s tématem této kapitoly, tedy vývojem člověka v kontextu profese učitele (a prrípravy na ni), je také třeba zmínit kariérní rozhodování, které samozřejmě nezačíná až v období vynořující se dospělosti. Jeho kořeny můžeme najít v př̀edchozích vývojových stadiích (srov. Messersmith et al., 2008) v podobě 
interakcí a zkušeností s př́slušníky konkrétních profesí (Lent et al., 1994; Whiston \& Keller, 2004). V této perspektivě má učitelské povolání dozajista výsadní postavení. Svou výraznou roli hraje i v procesu vnímání sebe sama a vlastních schopností v podobě zkušeností se školou (Lent et al., 1994) a zpětnou vazbou od vrstevníků (Jacobs, Davis-Kean, Bleeker, Eccles, \& Malanchuk, 2005). Výraznou roli v procesu rozhodování hrají i rodiče. Jacobs a Eccles (2000) upozorňují na čtyři hlavní oblasti vlivu rodičů: vytváření socioemocionálního klimatu, předvádění modelových rolí, zprostř̌edkovávání klíčových zkušeností a př̌edávání vlastních názorů a očekávání.

Z výzkumného hlediska je profesní rozhodování v období vynořující se dospělosti velmi zajímavým obdobím, zejména $s$ ohledem na specifický vývoj v oblasti světa práce (Arnett, 2004; Hamilton \& Hamilton, 2006). V tomto věkovém období dochází $\mathrm{k}$ integraci výstupů socializačních procesů z předchozích období s aktuálními zkušenostmi ( $v$ případě naší monografie s prací se školní tř́́dou) $s$ cílem zpřesnit kariérní volbu a sladit ji s dalšími dlouhodobými cíli. Z pohledu vzdělávacích institucí se u studentů jedná o nečekané změny $v$ podobě přechodu na tematicky poměrně vzdálené obory v rámci univerzit, přerušení studia či absolvování navazujících studijních programů jako způsobu odložení volby a podržení statutu studenta. Tyto změny obecně souvisejí se strukturálními změnami v pregraduální př́ípravě učitelů na Masarykově univerzitě po roce 2004 (srov. Mareš \& Beneš, 2013). Tyto změny přinesly možnost oborovou profesní volbu modifikovat, $\mathrm{z}$ hlediska subjektivního profesního vývoje však mohou být problematické, jakkoli dosud v centru zájmu stojí spiše kritika oborová (Stuchlíková, 2013).

Kunnen a kol. (2008; srov. Macek et al., 2016) upozorňují i na fakt, že profesní vývoj v období vynořující se dospělosti je úzce vázán i na vývoj v dalších životních doménách. Trajektorie vývoje závazků u univerzitních studentů ve vztahu k jejich subjektivní spokojenosti, stylu identity, strategií zvládání, vývoje osobnosti i vývoje jáství postihuje šest významných životních oblastí, mezi něž patří i profesní vývoj. Obecně lze říci, že vývoj, který lze charaktrizovat jako "nemít žádné závazky po delší dobu“, souvisí s větší pravděpodobností s problematickými vývojovými charakteristikami, než vývoj charakterizovaný menší explorací možností a přijetím závazku. Menší míra explorace zvyšuje spokojenost s výslednou volbou (v porovnání se stavem, kdy explorace chybí, nebo jí je více). Proces přijímání závazků je $\mathrm{v}$ období vynořující se dospělosti reversibilní a vývoj v dalších doménách (partnerské vztahy, bydlení, studium aj.) výrazně ovlivňuje i vlastní profesní vývoj.

$\mathrm{V}$ této souvislosti je dobré připomenout, že pro vynořující se dospělost je charakteristické hledání vlastní identity a profesní identita je jedním z dobrých př́kladů tohoto obecného procesu (Arnett, 2004; Hamilton \& Hamilton, 2006). Profesní identita (viz také kap. 1.2.2) předpokládá vývoj směřující k uvědomění si sebe sama i jako pracovníka. V moderních společnostech může být proces 
formování této identity obtížný a stresující. Úspěšné vyústění tohoto procesu př̌ináší silnou, autonomní, pozitivní a flexibilní profesní identitu, která je důležitým předpokladem pro pracovní úspěch, sociální adaptaci i subjektivní psychickou pohodu. Existují empirické důkazy, že vnímání práce jako povolání je spojeno s prř́znivými vlivy na duševní zdraví, zatímco vnímání práce ve smyslu kariérního růstu může být velmi prínosné, pokud jde o vlastní pracovní úspěch a subjektivní spokojenost (Skorikov \& Vondracek, 2011).

Součástí hledání identity je i rozvoj vlastní (profesní) autonomie (Mareš \& Mareš, 2014) jako důležitého předpokladu úspěšného výkonu profese. $Z$ hlediska pracovních aktivit je tedy pro vynořující se dospělé atraktivní vyhledávání takových pracovních aktivit, které umožňují seberealizaci a vyjádření vlastní identity a jsou i emocionálně hodnoceny odlišně od aktivit pragmaticky výdělečných. Často se proto může jednat o krátkodobé aktivity mapující různé aspekty profese. Určitě není překvapující, že právě tento typ zkoumání vlastní identity a kariérních možností přináší v důsledku větší uspokojení s vlastní kariérní volbou (Blustein, Phillips, Jobin-Davis, Finkelberg, \& Roake, 1997). Učitelská profesní př́íprava je v tomto směru specifická i nabídkou těchto aktivit jako integrální součásti studia (Pravdová, 2016).

\subsection{Raný profesní vývoj učitele}

Při zkoumání fungování jakéhokoliv konceptu v prostředí školy a třídy musíme vždy brát v potaz také kontext problematiky (profesního) vývoje učitele. To, v jaké fázi svého profesního vývoje se učitel nachází, se může odrazit např́íklad na podobě vztahů se žáky, na stylu výuky či obecněji na výsledcích výchovněvzdělávacího procesu. Možná ještě větší měrou se charakteristiky fáze vývoje projevují u začínajících učitelů a studentů učitelství na praxi, protože toto období často bývá spojeno s vyšším výskytem vývojových problémů, tenzí a dalších faktorů, které ve svém důsledku mohou vést $\mathrm{k}$ tomu, že student učitelství nakonec kariéru učitele ani nezačne či ji začínající učitel záhy opustí. Je tedy nezbytné uvažovat o studentovi učitelství (případně začínajícím učiteli) také z hlediska vývojové psychologie - tomuto tématu jsme se věnovali výše, především $\mathrm{v}$ souvislosti s konceptem vynořující se dospělosti (emergning adulhood). V pedagogické literatuře se lze, v návaznosti na předchozí koncept, setkat i s termínem vynořující se identita učitele - emerging professional teacher identity (srov. Chong, Low, \& Goh, 2011). Domníváme se, že tento koncept poskytuje dobrý rámec pro popis vývoje studenta učitelství.

O vývoji učitele uvažujeme z hlediska systémového pojetí, protože školy bývají považovány za otevřené systémy. Pro porozumění jejich fungování je důležité uvědomit si, že jejich podstatu netvoří jedinci (učitelé, žáci), ale především vztahy mezi nimi (Senge, 2000). Učitel i student učitelství je tedy součástí mnoha subsystémů školy, z nichž pravděpodobně nejdůležitějším a nejvíce sledovaným je 
školní třída. $V$ našem případě je specifickým subsystémem také samotný vztah student učitelství - cvičný učitel (podrobněji viz výsledky a diskuse v kapitole 4 a 5). Působení mnoha různých systémů ovlivňuje profesní vývoj učitele, stejně jako vývoj jeho osobnosti nebo jeho emocionální a kognitivní vývoj, na druhou stranu učitel různou měrou ovlivňuje systémy, jichž je součástí. Systémový pohled s sebou nese předpoklad, že vývoj učitele v takto složitém prostředí není jednoduše popsatelný a definovatelný, takže na mnohé z koncepcí raného vývoje učitele i studenta učitelství, které níže zmíníme, musíme nahlížet do jisté míry kriticky (podrobnější analýza viz Lukas, 2007, 2008). Hlavním důvodem kritického př́stupu může být skutečnost, že některá pojetí vývoje jsou občas v konfliktu se základními principy systémového pojetí, jakými jsou napr. zpětnovazební ovlivňování, celistvost či cirkularita (Watzlawick, Bavelas, \& Jackson, 1999; Bertalanffy, 1968). Jak uvidíme v kapitole 2 , obdobné systémové principy se vztahují i na uplatňování moci učitele v kontextu třídy.

Úvodem této podkapitoly se také nabízí důležitá otázka rozdílu ve využívání moci začínajícími učiteli na straně jedné a studenty učitelství na straně druhé či obecněji rozdílu v charakteristice začínajících učitelů a studentů učitelství. V některých pojetích vývoje učitele totiž autoři vnímají studenty učitelství jako jedince ve specifickém a samostatném vývojovém období (např. Fuller, 1969; Fessler \& Ingram, 2003), kdežto u jiných autorů charakteristiky studenta a začínajícího učitele do značné míry splývají (např. Steffy et al., 2000) a počáteční období ve vývoji učitele zahrnuje i přípravnou fázi, tedy studium učitelství. V této monografii budeme preferovat přístup druhý, protože z větší části jsou problémy, které ve výuce zažívají studenti učitelství a začínající učitelé, velmi podobné. Situace, úkoly a problémy, které jsou specifické pouze pro studenty učitelství a které mají souvislost $s$ tématem této knihy, pochopitelně v následujících kapitolách (především těch, jež představují výsledky našeho výzkumu) zmíníme také.

Můžeme také předeslat, že první zkušenosti s výukou a také začátek vývoje učitele patři dle některých autorů (Pietarinen \& Meriläinen, 2008) k těm fázím vývoje, které lze označit jako aktivní. Zmínění autoři předpokládají, že v průběhu celého profesního vývoje (právě s výjimkou prvního roku kariéry a prŕpravy na učitelství) se u všech učitelů střídají aktivní a pasivní fáze kariéry. To znamená, že v každém období vývoje může učitel $\mathrm{k}$ přicházejícím změnám přistupovat bud' aktivně (snaží se o cílevědomou adaptaci na situaci, „učí se“), nebo pasivně. Pasivní prrístup je charakterizován stagnací, snahou o používání dříve naučených způsobů zvládání různých situací ve třídě, což se studentů učitelství z principu př́liš netýká, protože mají ve svém repertoáru opravdu minimum dřive naučených strategií (nejčastěji pracují se strategiemi, které mají přejaté od učitelů, s nimiž se v průběhu své předchozí školní docházky setkali - viz níže). 


\subsubsection{Možné pohledy na vývoj studentů učitelství}

$\mathrm{V}$ dalším textu vycházíme především z konceptualizace problematiky vývoje učitele, uvedené $\mathrm{v}$ přehledových studiích Lukase $(2007,2008)$ - předpokládáme tedy, že existují širší a užší přístupy, z nichž některé jsou podloženy více psychologicky, jiné spíše odrážejí pedagogický pohled na vývoj učitele a nad nimi stojí pojetí komplexní (např. Fessler, 1995).

$\mathrm{Na}$ vývoj začínajícího učitele i studenta učitelství lze z hlediska užších psychologických pojetí nahližet jako na vývoj kognitivních procesů (percepce, myšlení, znalostí), které se týkají utváření a změn kognitivních struktur vztažených k různým aspektům učitelovy profese (Oja, 1990; Stroot et al., 1998; Torff, 2003). Jedno z užších psychologických pojetí, vycházejících z vývoje ega, nabízí Loevingerová (1976), která ve své teorii rozlišuje čtyři stádia. Z našeho pohledu je důležitá první, tzv. sebe-ochraňující fáze (self-protective), do níž lze zařadit učitele, kteří reagují ve vztazích se žáky impulzivně, nedokážou zcela řídit své emoce, jsou soustředěni více na sebe atd. Právě u studentů učitelství (a také začínajících učitelů) lze obdobné charakteristiky identifikovat poměrně často.

Dalším možným pohledem (Wubbels \& Levy, 1993), vycházejícím spíše z psychologických konceptů, je sledování vývoje učitelova interpersonálního chování během kariéry. Toto pojetí se odvíjí od základního předpokladu, že chování (způsoby komunikace) učitele a žáků lze hodnotit $\mathrm{z}$ hlediska míry spolupráce mezi nimi a míry kontroly a rízení interakcí, která naznačuje, kdo více určuje jejich průběh (viz také reciprocita moci v kapitole 2.5.3). Kontrolu interakcí a tedy míru vlivu (moci) učitele na třídu lze sledovat na kontinuu od dominantnosti k submisivnosti, jde tedy především o styl vedení třídy. Popis chování učitele v oblasti míry spolupráce naznačuje jeho blízkost $\mathrm{k}$ žákủm, tedy zda s nimi více spolupracuje nebo si od nich spiš udržuje určitý odstup. V souvislosti s tímto směrem výzkumu byl zjištěn rozdíl ve vývoji dimenze učitelova vlivu a dimenze blízkosti k žákům (Brekelmans \& Créton, 1993). Podle referencí žáků i samotných učitelů $\mathrm{v}$ dimenzi vlivu roste dominantnost učitele od počátku jeho kariéry. U začínajících učitelů a studentů učitelství je dominantnost poměrně malá, což vyplývá hlavně z faktu, že nemají téměř žádné zkušenosti se skutečným vedením druhých lidí. Začínají tak z pomyslného „bodu nula“ a svoji mocenskou pozici ve třídě si teprve postupně snaží budovat vykonáváním své učitelské praxe ${ }^{2}$. Co se týče dimenze „blízkosti“, tam se naopak dle výše zmíněných autorů projevuje tendence ke snižování učitelovy vstřícnosti s délkou jeho praxe. Začínající učitelé a studenti učitelství často začínají s velkou mírou prátelského, pomáhajícího a chápajícího chování, jež je jim bližší i vzhledem k jejich věku.

Mnoho modelů vycházejících spíše z pedagogických pojetí a koncepcí zabývajících se vývojem učitele se zaměřuje na vývoj jeho kompetentnosti. Např́ílad

2 U studentů učitelství je vzhledem k jejich postavení ve třídě situace poněkud složitější - podrobněji viz kapitola 4.2 o legitimní moci. 
Dreyfus a Dreyfus (1986) předkládají model pěti fází vývoje, kdy za jeden z hlavních znaků úspěšného vývoje učitele považují jeho narůstající flexibilitu v reakcích na různé situace, jež s sebou proces vyučování přináśí. Na první úrovni se tak dle těchto autorů nachází začínající učitel (novice), který se ve většině situací rídí danými pravidly a má „malý cit“ pro konkrétní situace - obdobné charakteristiky opět $\mathrm{z}$ větší části platí i pro studenty učitelství. Toto pojetí lze doplnit modelem „životních cyklů kariéry učitele“ (The Life Cycle of the Career Teacher), v němž se autoři pokoušejí brát $\mathrm{v}$ potaz skutečnost, že vývoj učitele je ovlivňován také interakcemi mezi jedincem a jeho okolím, a předkládají šest fází učitelova vývoje (Steffy et al., 2000). Jejich první fáze „nováčka“ (novice) začíná již s úvodními vlastními zkušenostmi studentů učitelství s podobou výuky a může být charakterizována nejistotou, snahou o zvládnutí základů vyučování a vedení tř́ídy a také (logicky předvídatelným) nedostatkem znalostí a dovedností k tomu potřebných.

Další z vlivných modelů vývoje kompetentnosti učitele nacházíme $\mathrm{v}$ pracích Fullerové, jejíž pojetí vývoje v sobě zahrnuje i období přípravy k učitelství a odvijí se od toho, co je pro učitele v určité fázi vývoje důležité a na co se především zaměřují - concerns based model (srov. Fuller, 1969; Fessler, 1995; Pigge \& Marso, 1997). V období př́pravy na učitelství se studenti prŕliš nesoustředují na vyučování jako takové, ale spíše na svůj vlastní vývoj jakožto studentů učitelství (preservice phase). Začínající učitelé se pak zaměřují především na to, jak se zhostit své nové role a "přežít" v ní, jak se vůbec stát učiteli (self concerns či survival concerns phase). Základní charakteristiky této následné fáze (začínajících učitelů) jsou dle našeho názoru $\mathrm{z}$ větší části platné i pro studenty učitelství. Koncepce vývoje učitele, kterou postulovala Fullerová především jako vývoj kompetentnosti, je v novějších výzkumech nadále využívána a rozšiřována. Například Conway a Clark (2003) tuto koncepci rozšiřují směrem, jenž více akcentuje i vnitřní (psychologické) faktory ovlivňující vývoj učitele. Autoři ve své studii dokládají, že učitelé se na počátku své kariéry zaměřují nejen na „vnějšni“ aspekty své práce (jak zvládnout výuku, jak přežít v nových situacích jako učitel), ale i na aspekty vnitřní, které nesouvisejí jen s vlastním „přežitím“, ale i se zaměřením na osobní zdokonalování a vývoj či celkově na změnu pojetí své identity (pojetí identity viz kapitola 1.2.2).

Model vývojových fází učitele, jenž je obdobně pojatý jako výše představená koncepce F. Fullerové, nacházíme u Katzové (1972). Podle ní jde v první fázi (survival), charakterizované soustředěním učitele na sebe sama a vcelku malým porozuměním pro žáky, začínajícím učitelům (či studentům učitelství) především o zvládnutí základních dovedností potřebných pro vyučování3. Opět s odkazem na Fullerovou označuje Long (1999) první etapu vývoje učitele jako počátek kariéry (career entry), který bývá charakterizován jednak již zmíněnou

3 Pro úplnost dodáváme, že oba posledně zmiňované modely se zdají být svojí charakteristikou survival fáze v rozporu se zjištěními Brekelmansové a Crétona (1993) o větší blízkosti začínajících učitelů k žákům. 
snahou o „přežiti“ $\mathrm{v}$ nové roli a pochopení rozdílu mezi představami a realitou každodenního procesu výuky (survival), jednak nadšením a objevováním nového (discovery), které se často dostane do konfliktu s realitou (reality shock). Wubbels se spoluautory (1993) obdobně konstatují, že v úvodu učitelovy kariéry se střetávají jeho ideály se skutečností - začínající učitel je většinou optimistický a snaží se, často neselektivně a neúspěšně, využít poznatky získané během studia na vysoké škole. K tomu, že nastavení funkčního uspořádání ve třídě je problém začínajících učitelů, dospěl na základě metaanalýzy výsledků 95 studií z USA a Evropy Veenman (1987), jenž také hovoří o šoku z reality, který mladé učitele po nástupu do profese zasáhne. Tento šok charakterizuje zborcením ideálů získaných během studia, $\mathrm{k}$ němuž dochází v kontaktu s realitou školních tř́d (v českém prostř̌edí stejné označení používá např. Švaříček, 2009). Obdobně hovoří Kremer-Hayon a Ben-Peretz (1986), kteří ve své studii týkající se překážek, $\mathrm{s}$ nimiž se začínající učitelé $\mathrm{v}$ počátcích své praxe setkávají, zdůrazňují právě šok z reality - moment, kdy si mladí učitelé uvědomí, že skutečná edukační realita je diametrálně odlišná od jejich původních představ o učitelství.

Poněkud odlišný pohled na vývoj učitele nám nabízejí Sikesová, Measorová a Woods (1985). Ti se zabývají spíše otázkou, jakým způsobem dochází k posunu učitele do jiné vývojové fáze a za podstatný považují koncept kritických (zlomových) fází a událostí. Pro tyto události je charakteristické, že hrají ústř̌ední roli v jedincově vnímání jeho kariéry a zároveň představují pro učitele významnou změnu, zlom v jeho celkovém vývoji (tedy nejen jako učitele). Podle Sikesové et al. (1985) existují určitá kritická období, která mohou mít souvislost přímo s profesí učitele, s jeho osobním životem, př́padně s vlivem společnosti jako celku. Autoři na základě výzkumů identifikovali šest kritických fází, které se zdají být závažné pro většinu učitelů, $\mathrm{z}$ nichž jsou pro naši monografii podstatné první dvě: rozhodnutí stát se učitelem a první zkušenosti s vyučováním. Relativně málo výzkumně podchycená a ve vzdělávání budoucích učitelů reflektovaná je první kritická fáze, tedy rozhodnutí stát se učitelem - kvalitativní studii pro naše edukační prostředí, věnující se této otázce zpracoval již dříve Gavora (2002), aktuálně lze toto téma částečně nalézt např. v práci Pravdové (2014). Sikesová et al. (1985) předpokládají, že některé zlomové, kritické události (critical incidents), spojené především s profesním vývojem, jsou více produktem občas neuvědomované krystalizace jedincova myšlení než vyústěním náhlých rozhodnutí či skutečných životních zlomů. Přestože jsou jednotlivé kritické události chápány u výše zmíněných autorů jako oddělené v čase, dovolíme si jejich pojetí poněkud upravit a předeslat jedno z parciálních zjištění z našeho výzkumu, které naznačuje určité prolínání výše zmíněných prvních kritických událostí ve vývoji učitele. Druhá fáze Sikesové et al. (1985), tedy první zkušenosti s výukou (v našem př́padě s praxemi na školách), se občas může do jisté míry prolínat $s$ „revizi“ fáze první (rozhodnutí stát se učitelem) - tzn. že právě počáteční zkušenosti s výukou někdy 
mohou ovlivnit dřivější rozhodnutí stát se učitelem, protože představy o učitelství jsou u studentů pedagogických fakult občas nejasné; jsou ovlivněny dřívějšími prekoncepcemi, nehledě na fakt, že většinou absolvují učitelskou př́ípravu jedinci ve fázi hledání své identity (viz níže).

V souvislosti se subjektivními kritickými událostmi jedinců v roli učitele lze zmínit důležitost tzv. kritických druhých ve smyslu signifikantních, pro vývoj učitele podstatných lidí (Woods, 1994), které můžeme chápat jako jedince mající na učitele výrazný vliv (a zároveň se většinou nenacházející na nějaké významné pozici ve vztahu ke škole). Tento koncept kritických druhých bychom v návaznosti na téma naší knihy poněkud rozšírili, protože jak dokládají níže zmíněné výzkumy, podstatný vliv na začínající učitele mají jejich uvádějící učitelé a obdobně u studentů učitelství je nezanedbatelný vliv učitelů cvičných (viz jedno $\mathrm{z}$ témat kapitoly 4.2 ).

Závěr této podkapitoly lze shrnout a doplnit výše zmiňované př́stupy $\mathrm{k}$ vývoji učitele o pojetí, která se zaměřují přímo na vývoj studentů učitelství a jež jej prezentují do jisté míry jako obdobu vývoje učitele během celé jeho kariéry (Furlong \& Magnard, 1995; Shkedi \& Laron, 2004). Již v průběhu studia (především pak praxí) lze ve vývoji studentů zaznamenat v podstatě obdobné fáze, jako jsou ty, odrážející kompletní vývoj učitele. Ve fázi první, v souladu s předchozími koncepcemi, lze u studentů učitelství hovořit o raném idealismu, který můžeme charakterizovat jejich tendencí identifikovat se spíše se svými žáky než s učiteli (viz také kapitola 4.6, věnovaná referenční moci u studentů učitelství). Ve druhé fázi u studenta učitelství většinou dochází k výrazné (negativní) korekci jeho idealistických očekávání, takže se v tomto období začíná soustředovat především na „osobní přežití. Jednou ze strategií může být napodobování dle něj fungujících postupů jiných učitelů (např̀. učitele cvičného). Ve třetí fázi se student učitelství učí „Zacházet s obtížemi“ (dealing with difficulties), protože již začíná být schopen identifikovat problémy, které jeho práci ve škole komplikují, a také začíná být mimo jiné vnímavější k používání různých výukových metod. $\mathrm{V}$ další fázi, obrazně nazvané hitting the plateau (Shkedi \& Laron, 2004), pak studenti učitelství do jisté míry akceptují svoji roli učitele, takže si již začínají uvědomovat, že už nejenom "vystupuji“" jako učitelé, ale že v jistém smyslu učiteli „jsou“. V návaznosti na první část této kapitoly tedy můžeme říci, že v této fázi vývoje dochází k postupnému přijímání závazku (commitment), což dokládá i pojetí poslední fáze (Furlong \& Magnard, 1995) ve vývoji studenta učitelství (moving on). Mimo jiné se $\mathrm{v}$ tomto období student vědomě vzdává moci, která mu byla pouze dočasně svěřena (mj. cvičným učitelem), a začíná o sobě postupně uvažovat opravdu jako o učiteli. 


\subsubsection{Vývoj identity: tenze a dilemata $\mathrm{v}$ přechodech $\mathrm{z}$ role studenta do role učitele}

Již na předchozích řádcích jsme naznačili, že vývoj učitele může být chápán jako vývoj jeho identity v průběhu kariéry, přičemž pojem identita primárně vychází z psychologického pohledu na vývoj jedinců: jde o utváření jejich adekvátního vnímání sebe sama jakožto učitelů. Za hlavní vnitřní faktor vývoje identity můžeme považovat "představu“ jedince o tom, jak by se měl v určité roli chovat. Zároveň však existují vnější faktory ovlivňující vývoj identity, ke kterým patří mimo jiné vztahy s ostatními lidmi - především pak s těmi, kteří zastávají obdobnou roli (Pittard, 2003). Také připomínáme fakt, že identitu učitele nelze chápat jako statický, pro jednou vytvořený „stav“, nebot v průběhu studia a následujících fázích vývoje dochází k neustálému, a často emocemi ovlivněnému, rekonstruování identity v závislosti na měnící se míre sebepoznání učitele, na jeho vnímání své profese či na změně představ o svém budoucím směřování (Mayer, 2011).

V souvislosti s vývojem začínajícího učitele (a studenta učitelství) a formováním identity lze také uvažovat o situacích, kdy je vnitřní identifikace s rolí učitele nejasná nebo prímo utilitární (ve smyslu „je to prostě práce“). Na druhou stranu již studenti učitelství a někteří začínající učitelé mohou do jisté míry spojovat svůj osobní a profesní vývoj v jedno (což mimo jiné vyžaduje větší „osobní investici"). Lze tedy v této souvislosti nabídnout určité zjednodušení - totiž že studenti učitelství (i začínající učitelé) mohou přemýšlet o svém budoucím uplatnění v profesi dvěma způsoby: „chci pracovat jako učitel“ vs. „chci být učitelem“" (srov. Friesen \& Besley, 2013). Vývoj identity učitele (se zdůrazněním zaměření na aspekt „být učitelem“) tak je často chápán a popisován jako stávání se učitelem (becoming a teacher). Tento neustálý proces souvisí mj. s učitelovým určováním si smyslu učení, který je získáván a formován spolupůsobením mnoha faktorů, kdy na „nejnižši úrovni uvažujeme o osobnosti jedince a na nejvyšší o celé společnosti, reprezentované např. zájmovými skupinami či vládami (srov. van Huizen, 2000). Na tomto místě je třeba zmínit také relativně málo zkoumaný fenomén týkající se vlivu samotného prostředí vysokých škol připravujících budoucí učitele na vývoj jejich identity. Organizační nastavení konkrétních vysokých škol či kontakty jedince se spolužáky, kteří se také připravují na učitelské povolání, tvoří nedílnou součást vývoje identity učitele - někteří autoři (Weidman, 2006) hovoří přímo o jistém modelu změn ve vývoji studentů učitelství (college impact of student change).

Vývoj identity učitele tedy formuje mnoho faktorů - interakce s okolím, dřívější zkušenosti s učením i „životni“ zkušenosti, osobnostní předpoklady včetně schopnosti sebereflexe, institucionálně dané možnosti a limity vývoje, existence skupinově reflektované či odborně instruované a korigované zkušenosti s výukou apod. (Allen, 2005; Franzak, 2002; Walkington, 2005). Významný vliv na vývoj identity učitele mají také samotní žáci, jejich potřeby a očekávání, jež ovlivňují 
formu (někdy částečně i obsah) výuky konkrétního učitele (srov. Proweller \& Mitchener, 2004). V kontextu vývoje identity výzkumy naznačují, že počáteční vývoj profesní identity učitele je formován představami o vyučování, které jsou tvořeny vlastními předchozími zkušenostmi $\mathrm{v}$ roli žáka a také obrazem učitelů, s nimiž se studenti učitelství během školní docházky setkali (Chong \& Low, 2009). Vliv předchozích zkušeností patří k širší skupině možných okolností, které při formování profesní identity začínajících učitelů (ale možná ještě více studentů učitelství) způsobují různě závažné tenze, $\mathrm{k}$ nimž patří např́klad nesoulad mezi následováním svého cvičného (uvádějícího) učitele a hledáním své vlastní cesty (Pillen, den Brok, \& Beijaard, 2013). Obdobně se v literatuře můžeme setkat také s označením dilemata v období raného vývoje učitele (např. Mayer, 2011).

U studentů učitelství, kteři se poprvé dostávají do kontaktu s výukou, také dochází k jisté tenzi mezi očekáváními a představami s reálnou zkušeností jejich praxí na školách (Chong \& Low, 2009). Zmínění autoři (a také např. Shkedi \& Laron, 2004) hovoří o tom, že studenti učitelství rozhodně nejsou ve vnímání role a práce učitele pomyslná tabula rasa. Na vysoké školy a poté i do výuky totiž přicházejí s často nesdělitelnými miskoncepcemi, jež mají spojeny s podobou výchovně-vzdělávacího procesu, a jejich zjednodušené představy o skutečné práci učitele se poté odrážejí i ve zjednodušeném pojetí jejich skutečné práce se tř́́dou. 


\section{FENOMÉN MOCI A JEHO SOUVISLOST SE ŠKOLNÍM PROSTŘEDÍM}

Kateřina Lojdová, Zuzana Šalamounová, Jarmila Bradová

V předchozí kapitole jsme nastínili vývojové období, v němž studenti učitelství vstupují na své první praxe, prostřednictvím pocitu „mezi adolescencí a dospělostí“ a spolu s tím také tendencí identifikovat se spíše se svými žáky než s učiteli. Tyto charakteristiky proto musíme zvažovat jako proměnné, které se do výsledné podoby mocenských vztahů mezi studenty učitelství a jejich žáky mohou promítat. $\mathrm{V}$ této kapitole se tedy podrobněji zaměříme na fenomén moci a na to, co vše se na jeho podobě může podílet. Linie výkladu začíná představením moci jako tradičního konceptu sociálních věd. Poté se zaměříme na její pojetí v mikrokontextu školní třídy a v širším kontextu, který mocenské dění ve tř́dě ovlivňuje. Vymezíme fenomén moci pro účely našeho výzkumu a představíme báze moci učitele, jímž jsme se výzkumně věnovali.

\subsection{Moc v sociálních vědách}

Fenomén moci, definovaný jakožto potenciál ovlivňovat postoje, hodnoty a jednání jiné osoby nebo skupiny osob (Richmond \& McCroskey, 1992), je jedním $\mathrm{z}$ tradičních témat sociálních věd (srov. např. Foucault, Parsons, Simmel, Weber, ad.). Moc je v sociálních vědách pojímána analogicky $\mathrm{k}$ fyzice jako kontinuálně se transformující síla, přičemž jsou zkoumány zákony této transformace (Russell, 2004). Coates (1991) přirovnává pojem moc $\mathrm{k}$ takovým konceptům v prrírodních vědách, jako je například gravitace, jež je také velmi obtížně popsatelná, ale která svým působením ovlivňuje vše ostatní. Moc je přítomna ve všech vztazích ve společnosti, počínaje mocenskými vztahy mezi státy nebo uskupeními států, a konče např. vztahy mezi manžely, v rodině či právě ve školní třídě. Moc se nenachází jen ve vztazích nadřazenosti a podřazenosti, ale i mezi aktéry na stejných pozicích, kde je vzájemný vztah rovnocenný (Cook \& Emerson, 1978). Přestože je koncept moci ústřední pro porozumění sociální realitě, je to jeden z konceptů nejobtížněji uchopitelných (Haugaard \& Clegg, 2009).

S mocí se často pojí dvě miskoncepce. První miskoncepcí je chápání moci jako vlastnosti jedince nebo skupiny ( $\mathrm{k}$ čemuž ostatně přispívá také valence pojmu moc v českém jazyce). Přestože se v běžném jazyce používá sousloví „mít moc“, přesnější vyjádření je „být v mocenské pozici“. Moc totiž není primárně atributem osoby, ale jevem vztahovým. Foucault (2005) tuto skutečnost vysvětluje tak, že moc není privilegium vlastněné někým v dominantní pozici, ale efektem této strategické pozice. $S$ tím souvisí důležitá role protistrany držitelů moci 
- uplatňování moci je totiž závislé na její percepci protistranou - pokud moc není vnímána, nemůže být uplatňována (Richmond \& Roach, 1992). Nositelé moci tak bez protistrany, která jejich moc akceptuje, nemohou být v mocenské pozici. Moc proto nelze vymezit unilaterálně - k její definici i zkoumání je nutné přistupovat jakožto ke vztahu (srov. Goffman, 1999; Kaščák, 2006; Woods, 1983), z interakcionalistické perspektivy (Staton, 1992).

Druhá miskoncepce spojuje moc s negativními konotacemi. Částečně k tomu může přispívat i slavná Weberova definice moci jako "pravděpodobnosti, že jeden aktér sociálního vztahu bude v pozici, kde prosadí svoji vưli i přes rezistenci druhé strany, bez ohledu na to, z čeho tato pravděpodobnost prameni" (Swedberg \& Agewall, 2005, s. 205). Rezistence je přirozenou součástí moci, moc obvykle produkuje nějakou podobu rezistence (Danaher, Schirato, \& Webb, 2000), což ovšem samo o sobě nemůžeme označit za negativní či pozitivní. Koncept moci spojený s dominancí a násilím navíc převažuje v běžném jazyce. Pokud se člověka zeptáme, jak by neverbálně vyjádřil moc, často zvedne zatnuté pěsti jako určitý symbol hrozby. Lidé tak mají tendenci moc spojovat $s$ vítězstvím nad někým jiným (Boulding, 1989).

V sociálních vědách je tomu však dle Clegga a Haugaarda (2009) naopak, pojem moc sám o sobě zde nemá negativní konotace. Boulding (1989) rozlišil tři druhy moci: destruktivní, produktivní a integrativní. Tyto druhy moci nicméně mají různé významy a prolínají se: destruktivní moc může sloužit k ničení i k obraně, někdy je potřeba něco zničit, abychom mohli vyprodukovat něco nového; pokud něco společně produkujeme, je $\mathrm{k}$ tomu zapotřebí určitá důvěra, tedy integrativní komponent moci atd.). Moc na jednu stranu může být prostředkem donucování, represí, násilí, na druhou stranu je však také prostředkem sociální koheze a normality, a umožňuje tak fungování komunit. Foucault tuto nejednotnost pojmenovává jako dvojitý metodologický princip analýzy moci (Foucault, 1980, s. 235). Foucault (ibid.) odhaluje moc, kterou moderní doba nese, skrze instituce jako jsou věznice, psychiatrické léčebny, nemocnice, továrny a samožrejmě i školy. Ukazuje moc jako skrytou sílu, jež utváří a proměňuje každodenní život jednotlivců. ${ }^{4}$ Sleduje, jak moc ovlivňuje tělo jedince (skrze moc je totiž možné lidské tělo zkoumat, označovat, trénovat, zapojovat do ceremoniálů, mučit) a operuje na mikroúrovni jedinců. Pokud např́klad žáci nosí ve škole stejnokroj, manifestují skrze své tělo mocenské aspekty instituce, která tento stejnokroj předepisuje. Moc je prritom pro Foucaulta (2005) spíše produktivní nežli destruktivní silou. Bez moci by např́iklad nebylo vědění, nebot’ jedno předznamenává druhé - každé vědění předpokládá konstituci mocenských vztahů a každá moc konstituuje vědění.

Moc může mít různé podoby. Moderní společnosti již podle Gramsciho (2005) nestojí na represivní moci (pro zajímavost toto napsal z vězení ve fašistické Itálii).

4 Foucaultovu typologii mocenských technik vzešlých na základě analýzy trestání využívá Gore (1995), která je aplikovala na školní prostředí a ilustrovala je kvalitativními daty. Ve školním prostředí ukazuje techniky dohledu, normalizace, exkluze, klasifikace, distribuce, individualizace, totalizace a regulace. 
Moc je v nich vyjádřena hegemonií. Hegemonie je kulturní a intelektuální dominance vládnoucí třídy skrze systém hodnot, norem a sociálního řádu. To, že se moc vztahuje k určitým sociálním pozicím ve společenské hierarchii, vyjadřuje také koncept symbolické moci (či symbolického násilí), jenž rozvinul Bourdieu. Nejedná se o typ moci, ale o aspekt moci, který je každodenní součástí společenského života. Symbolické násilí může být silnější než fyzické násilí, protože je méně patrné a zároveň všudypř́itomné skrze sociální řád (Bourdieu, 1991).

Sociální vědy přispívají k porozumění, jak různé síly modifikují chování jednotlivců a skupin, kontrolují jejich chování a utvářejí jejich životy (Harrington, 2006). Tyto děje se odehrávají i v edukačních souvislostech. Na fenomén moci dále nahlédneme v prostř̌edí školní tř́ídy, kde má větší význam, než se na první pohled může zdát.

\subsection{Moc ve školní třídě}

Školní třída je sociálním prostředím, v němž se odehrává množství sociálních jevů. Jádrové jsou jevy didaktické - žáci chodí do školy především proto, aby se něčemu naučili. I když to není na první pohled zjevné, skrze koncept moci se zabýváme didaktickou oblastí v širších souvislostech. Sledujeme jevy, které rámují výchovně-vzdělávací proces. Sebekvalitnější učitelova znalost obsahu učiva totiž zůstává bez třídy s jasně nastavenými mocenskými vztahy bez užitku (Šalamounová \& Švaříček, 2012). Lze proto říci, že ustanovení mocenských vztahů je ve školní tř́́dě determinantou realizace cílů didaktických. To koresponduje s tvrzením Bernsteina (1996), že ve školní třídě je dominantní diskurs regulativní, do něhož je vložen diskurs didaktický. Zatímco regulativní diskurs definuje pravidla sociálního chování a vztahů ve škole, didaktický diskurs určuje, jaké znalosti budou žákům předávány. Oddělení obou diskursů je spíše modelové, protože $\mathrm{v}$ realitě školní třídy se tyto diskursy př̀krývají. Docházíme tak k tomu, že k předávání didaktického obsahu vždy dochází prostřednictvím uspořádání diskursu regulativního. Jinými slovy, pokud učitel „nezvládne“ třídu z hlediska vytvoření učebního prostř̌edí, těžko může naplnit svoje didaktické cíle. Ve snaze naplnit didaktické cíle tedy neustále dochází k vyjednávání a uplatňování moci učitele, které je stěžejním předpokladem procesu výuky (McCroskey \& Richmond, 1983). Například i výborně připravená hodina může pro začínajícího učitele skončit nezdarem $\mathrm{v}$ prŕpadě, že nedokáže uplatňovat svoji moc $\mathrm{v}$ roli učitele či distribuovat moc žákům tak, aby ji využili k naplňování didaktických cílů.

Moc ve školní třídě je přirozenou součástí výchovně-vzdělávacího procesu. Moc můžeme ve vztahu k učiteli chápat jako učitelovu schopnost ovlivnit žáky v tom, aby činili, co po nich učitel požaduje (Kearney et al., 1985). To je v souladu se Štechovým (1994) vymezením učitelské profese, ve kterém jde o to, identifikovat logiku výkonu profese, její konstanty dané tím, že se jedná o vztah a o vyvíjení vlivu na druhou osobu v tomto vztahu. Zde je třeba připomenout, že 
učitelova moc existuje jen tehdy, pokud ji žáci percipují a akceptují ji (Richmond \& McCroskey, 1984). Učitelé se občas podivují, že jejich odměny a tresty nefungují. Jedním z možných zdůvodnění z perspektivy moci je to, že jsou odměnami a tresty jen pro učitele, nikoliv pro žáky. Tento př́klad ukazuje, že výkon moci učitelem je inherentním součástí vyučování. V souladu s definicí moci je tento výkon neutrální, respektive může produkovat pozitivní i negativní výsledky (McCroskey \& Richmond, 1983). Učitel může moc využít i zneužít, a to nejen vědomě, ale i nevědomě (srov. skryté kurikulum ${ }^{5}$ ). Cesty $k$ udržení moci učitelem jsou různé. Lewis (2001) připomíná, že nastolení klimatu vhodného pro učení může být dosaženo nejen důrazem na poslušnost a donucování, ale i vyjednáváním se žáky, diskusí, skupinovou účastí a kontrakty.

Učitelé však nejsou jedinými aktéry ve školní třídě, kteří mohou získat vliv. Do mocenských vztahů ve školní tř́dě vstupují sami žáci. Moc se projevuje mezi žáky navzájem a žáci mohou vystupovat mocensky i vůči učiteli. Za klasickou lze v tomto ohledu považovat etnografickou studii Woodse (Hammersley \& Woods, 1984), který diferencuje typy žákovského chování při adaptaci na požadavky učitele do šesti podob: konformita (žáci nadšeně souhlasí s cíli učitele), ritualismus (akceptace norem ve škole, aniž by se žáci s těmito normami ztotožňovali), únik (lhostejnost $\mathrm{k}$ cílům školy, žáci se nenápadně věnují únikovým činnostem), kolonizace (žáci přijímají školní normy a postoje, avšak za účelem naplnění vlastních cílů), nesmíření se (lhostejnost k cílům školy, projevuje se vyrušováním, provokováním), rebelie (odmítnutí požadavků školy, projevuje se otevřenou vzpourou nebo chozením za školu). Zejména poslední dva typy chování žáků vstupují mocensky do opozice ke školním normám.

Zatímco Woodsova typologie zachycuje především sílu mocenského vstupu žáků, typologie Šed’ové (2011) bere v potaz dvě kritéria: 1) zda je moc spíše v rukou učitele, nebo žáků, 2) zda jsou cíle učitele a žáků společné, nebo rozdílné. Ve výsledné typologii čtyř mocenských konstelací (zobání z ruky, přesilovka, cirkulace, tahanice) uvádí Šedová dvě z nich, kde mají převažující vliv žáci (cirkulace moci a tahanice). Liší se však sdílením cílů žáků s učitelem. V cirkulaci moci učitel slevuje ze své dominance ve prospěch žáků. Učitel a žáci přitom sdílejí společné cíle. Žáci jsou angažovaní, pokládají otázky k učivu. Ten, kdo se dotazuje, má $\mathrm{v}$ dané mocenské konstelaci chvíli mocenskou převahu. Oproti tomu v tahanici žáci s učitelem cíle nesdílejí, berou vyučování jako příležitost otestovat vlastní síly a pobavit se. $V$ důsledku toho pak nedochází k plnému dosažení edukačních cílů.

Projevy, kterými se žáci snaží vyhnout požadavkům učitele či dosáhnout vlastního záměru, jsou označovány jako rezistence žáků (srov. Lojdová, 2015). Rezistenci definujeme jako opoziční akt k něčemu, s čím jedinec nebo skupina

5 Jako skryté kurikulum lze označit vše, co se žáci ve škole učí, a není to záměrně komunikováno učiteli a školním systémem (Hargreaves, 1982). Hemmingsová (2000) uvádí, že výzkumníci skrze skryté kurikulum zejména popisovali, jak se reprodukují sociální, rasové a genderové rozdíly. 
nesouhlasí (Sannino, 2010) a můžeme ji chápat jako soutěž o moc. Rezistentní chování žáků je manifestováno jako neochota učit se, odmítání školy, neangažovanost a apatie, neplnění požadavků, vzpurnost (Hendrickson, 2012). Rezistentní chování se často projevuje nekázní, ale ne každá nekázeň je rezistencí. Rezistenci můžeme označit za specifický typ nekázně. $\mathrm{V}$ teoriích rezistence toto chování není připisováno odchylkám žáků, nýbrž převážně vnějším vlivům. Tyto vlivy shledávají autoři jak prŕmo v prostředí školní třídy, tak i v širším makrosociálním kontextu. V mikrosociálním pohledu je rezistence vnímána jako reakce na opresivní prvky školy, např́ílad přímo na učitele či na žákủm vzdálené kurikulum (Dickar, 2008). Mnohdy je snahou žáků skrze nevhodné chování vzbudit pozornost učitele (Gootman, 1997). Nudný výklad učitele, jeho př́lišné nízké nároky (Holt, 1984) nebo naopak nároky pŕíliš vysoké mohou také k tomuto chování žáků přispět (Bryant \& Bates, 2010). Žáci mohou být ve třídě rezistentní také proto, že podoba vyučování neodpovídá jejich mentálním modelům učení a prekonceptům, jenž si do třídy přinášejí (např. role učitele a žákủ, cíl vzdělávání atd.) (Brookfield, 2006). Ve třídě může dojít až $\mathrm{k}$ aktivnímu odporu vůči učitelově osobě. $\mathrm{V}$ takovém př́padě žáci směřují $\mathrm{k}$ aktivní nekázni, odmítají učitele „Z principu“ či používají vulgární vyjádření. Opačnou strategií bývá pasivní rezistence - apatie, deklarovaný nezájem (srov. např. Kearney \& Plax, 1992; Lojdová, 2015). Rezistence žáků nemusí být jen v rozporu s cíli učitele a společenskými normami. Oproti antisociální rezistenci můžeme vymezit rezistenci prosociální či neutrální (Golish \& Olson, 2000; Kennedy-Lightsey \& Myers, 2009). K rezistenci je také třeba poznamenat, že rezistence žáků vůči učitelům může být dána neadekvátními požadavky učitele, ale může také být jen rétorickou figurou, skrze kterou přenášejí žáci odpovědnost za své chování na učitele (Šedová, 2011). Školní trrída se tak jeví jako prostředí s množstvím podob moci a rezistence. Obzvláště pro studenta učitelství či začínajícího učitele jsou tyto fenomény velkou výzvou. Přiblížíme proto specifika moci u začínajících učitelů.

\subsubsection{Vstup do třídy a pojetí moci u začínajících učitelů}

Výzkumná šetření dokládají (Richmond \& Roach, 1992; Staton, 1992; Lukas \& Švaříček, 2007), že mocenské uspořádání ve třídách začínajících učitelů či studentů, kteři stojí před vstupem do profese, bývá často problematické. Učitelé po skončení profesní přípravy, na začátku své kariérní dráhy, totiž mnohdy nevědí, jak adekvátně dostát požadavkům na ustavování moci ve svých třídách.

V návaznosti na předchozí text se nyní můžeme zaměřit na to, proč se právě mocenské uspořádání ve tř́íách u začínajících učitelů a studentů učitelství stává potenciální Achillovou patou tohoto vývojového období. Jako první z důvodů lze uvést problém $\mathrm{s}$ definováním cílů a dosahováním shody v těchto cílech mezi učitelem a žáky. Z výzkumu Winograda (2002) v této souvislosti vyplývá, 
že začínající učitelé stejně jako studenti učitelství v důsledku své nezkušenosti mnohdy nemají jasnou vizi toho, čeho by ve školní tř́idě chtěli dosáhnout. K podobným závěrům v českém prostředí dospěl také Švaříček (2009), který v rámci biografického výzkumu životní dráhy učitelů expertů konstatoval, že učitelé v počátečních fázích působení ve své nové roli sice vědí, co ve své vlastní praxi konat nechtějí, avšak nemají zcela jasno v tom, co by vykonávat chtěli. V tomto okamžiku je obtížné dosáhnout s nimi shody v definici situace, v níž se nacházejí, nebot jejich vlastní vnímání identity a situací s ní spojených je velice obtížně definovatelné. Začínající učitelé navíc doposud mnohdy nejsou ztotožněni se svou rolí učitelů a stále sebe sama vnímají spíše „na druhé straně“ (Lukas \& Švaříček, 2007). Všechny zmiňované důvody vedou $\mathrm{k}$ tomu, že začínající učitelé i studenti učitelství mohou být z hlediska definování cílů výchovně-vzdělávacího procesu nejistí, a tím z pohledu svých žákủ nečitelní, což snadno může vést ke konfliktnímu uspořádání vztahů ve třídě. Winograd (2002) z této zkušenosti u svých studentů učitelství usuzuje, že je zásadní s nimi pracovat na definování jasných a ze strany žáků dekódovatelných cílů a hledání způsobů, jak těchto cílů dosáhnout, což vnímá jako silný impulz pro učitelskou př́pravu. Na druhou stranu ovšem dodejme, že období, kdy studenti učitelství a začínající učitelé vstupují do praxe, je specifické právě tím, že se jedná o tzv. období hájení - právě v této fázi mohou dělat chyby, být neúspěšní (Lukas \& Švaříček, 2007) a postupně najít svoji vlastní cestu, jak se vyrovnat s nástrahami učitelské profese, mezi něž patří také funkční uspořádání mocenských vztahů (připomínáme, že se stále u námi zkoumaných studentů učitelství pohybujeme ve fázi hledání identity a snahy přijmout očekávaný závazek).

Definování cílů úzce souvisí se schopností přípravy funkčního plánu hodiny. Učitelé na startu své profesní dráhy sice zpravidla disponují kvalitními znalostmi oborového obsahu, nicméně mohou mít problémy $\mathrm{s}$ tím, které $\mathrm{z}$ nich $\mathrm{v}$ hodině předat a jakým způsobem (Cothran \& Ennis, 1997). Postřehy učitelů, kteří už za sebou mají delší praxi, dokládají, že plány zejména u studentů učitelství jsou precizní, nicméně v reálném světě třídy často nerealizovatelné. To může opět vyústit v mocenské uspořádání, které je svou povahou konfliktní, nebo v němž žáci prrípadně hledají únikové strategie (např pěstování fantazií a nerealistického obrazu vlastního působení). Jedná se přitom svým způsobem o začarovaný kruh, nebot když se žáci nudí, trpí i kvalita jejich práce, protože ji vykonávají mechanicky a bez rozmýšlení, čímž se pro ně přirozeně ztrácí její smysl. Žáci tak nevyhnutelně dál pozbývají zájem o výuku. Jejich cíle a cíle učitelů se postupně rozcházejí, definice situace se rozrůzňují a uspořádání ve třídě se dál vzdaluje od kooperace.

Druhým opakovaným důvodem toho, proč může být mocenské uspořádání ve třídách začínajících učitelů a stejně tak studentů učitelství problematické, lze hledat $\mathrm{v}$ rovině interpersonálních vztahů učitelů a žáků. Budoucí a začínající učitelé pochopitelně mohou se svými žáky vstupovat do celé palety vztahů, 
nicméně - jak jsme uvedli - vzhledem $\mathrm{k}$ jejich věku a pozici na startu profesní dráhy je pravděpodobnější, že se budou chtít stát spíše přátelskými učiteli (Brekelmans \& Créton, 1993; Moscovici, 2007). Ačkoli se jedná o vztah, který je z hlediska dosahování kooperace ve tř́iě optimální, objevuje se právě v rámci tohoto vztahu riziko spojené s nastavením adekvátní hranice. Např́íklad Aultmanová, Williams-Johnsonová a Schutz (2009) na základě svého šetření založeném na hloubkových rozhovorech $s$ učiteli výrazně rozlišují mezi tím být př́tel žáků a být přátelský, a podotýkají, že identifikace demarkační linie může být na začátku praxe velmi problematická. V českém kontextu se lze opřít o výzkum Šed’ové (2011, 2012), který dokládá, že učitelé, jejichž vyučovací hodiny vykazují personální orientaci a u nichž přitom nedojde ke shodě v definici situace s jejich žáky, jsou v zásadě učitelé začínající.

Do třetice proti studentům učitelství (opusṫme zde na okamžik začínající učitele) stojí také některé $\mathrm{z}$ kontextuálních proměnných. Je pro ně totiž poměrně obtížné dosáhnout ve tř́dě autonomie v plánování výuky (srov. Ingersoll, 1996), nebơ plán výuky je jim často jednoduše předán jejich cvičným učitelem. Jejich vztah s vedením školy (srov. Cothran \& Ennis, 1997) i rodiči prozatím neexistuje a mnohdy během období praxe ani nemusí být vytvořen. To, co se ve školní tř́dě odehrává, je tedy zasazeno do širšího makrosociálního prostředí. K dokreslení moci ve školní třídě proto nahlédneme i za její hranice.

\subsection{Moc za hranicemi školní třídy}

Za hranicemi školní třídy se nachází kontext, do něhož je mocenské uspořádání zasazeno. Pokud tedy chceme uvažovat o mocenském uspořádání ve školní třídě, měli bychom vzít v potaz také sociokulturní a historický makrokontext a kontext školy, který dění ve třídě determinuje.

Jedním z prvků sociokulturního kontextu, jenž tvoří pozadí mocenských uspořádání ve tř́dách a může se vyjevit zejména v mezních situacích, je samotný fakt, že školní docházka je povinná. Žáci jsou proto nedobrovolnými návštěvníky škol a činnost ve škole pro ně často není příliš zajímavá (Winograd, 2002). Historickou perspektivu do tohoto uvažování vnáší Foucault (1978, s. 344), který argumentuje, že mocenské uspořádání je vždy prezentováno řadou instrumentů, kam spadají např́íklad aktuální vzdělávací dokumenty a programy, strategické dokumenty a nástroje. Foucault (1978) dále hovoří také o tzv. strukturální limitaci, jež vymezuje, co je ve třídě možné a co již nikoli. Strukturální limitace tedy ustavuje například nepř́ípustnost určitých trestů a hrozeb ve třídě (Winograd, 2002, s. 345; přehled v českém prostředí přináší napřr. Rigel, 2012).

Dalším podstatným faktorem je proměna toho, jak je celospolečensky nahlížena role učitele. Tomuto tématu se v americkém kontextu věnuje Ennisová (1995), která podotýká, že pozice učitele donedávna, bez ohledu na osobnostní charakteristiky, získávala respekt, což již dnes neplatí. Respektování role učitele 
(a tím percipovaná legitimní moc vyplývající z této role) např́klad na středních školách bylo dříve dáno také hodnotou středoškolského diplomu, který žáci získávali. Dnes však úspěch ve škole negarantuje ekonomickou úspěšnost po absolvování studia (srov. Keller \& Tvrdý, 2008), takže učitelé mají menší vliv na život svých žáků (Cothran \& Ennis, 1997). S tím, jak je vnímána pozice učitele, souvisí také lokalita a region, v nichž se škola nachází (Oyler, 1996; Elias \& Mace, 2005), a předpokládané studijní aspirace žáků (Oyler, 1996). Vztah školy a sociální tř́ídy ilustruje napríklad Willisova studie Learning to Labour (1977) zachycující zesměšňování školy chlapci z dělnických rodin jako aktivní strategii vůči tomu, aby je škola socializovala jako poslušné dělníky. Význam lokality zase odhalila studie na střední odborné škole $\mathrm{v}$ americkém rurálním Ohiu (Hendrickson, 2012). Na místní stř̌ední školu přicházejí učitelé z města s cílem poskytnout širší vzdělání. Studenti jsou však úzce svázáni s rodinou, již nechtějí opustit a která je podporuje v tom, aby si našli hůře placenou práci v zemědělské lokalitě. Studenti proto posuzují stř̌edoškolské kurikulum jako irelevantní, mají pocit, že jim učitelé nerozumějí, a někdy pro ně nejsou adekvátní ani normy školy ${ }^{6}$.

$\mathrm{Na}$ úrovni školy jakožto instituce se $\mathrm{v}$ zahraniční literatuře uvažuje zejména o vztazích mezi učiteli a žáky a dalšími aktéry života školy. Pozornost se přitom hojně věnuje vztahu učitelů a vedení školy. S oporou o šetření Cothranové a Ennisové (1997) lze např́klad říci, že učitelé sebe samé vnímají jako více schopné zasáhnout do mocenského nastavení ve třídě ve chvíli, kdy se cítí podpořeni vedením. Učitelé v tomto výzkumu však vypovídají o dominantním nezájmu ze strany vedení školy, v důsledku čehož necítí podporu své práce. Dalším faktorem, který se ve svém důsledku promítá také do mocenského uspořádání ve školní třídě, je míra autonomie učitele $\mathrm{v}$ souvislosti se vzdělávacími procesy ve třídě. Na základě reprezentativního dotazníkového šetření udává např́iklad Ingersoll (1996), že čím větší je míra autonomie učitele ohledně dění ve třídě, tím nižší je míra konfliktů, $\mathrm{k}$ nimž ve tř́dě mezi učitelem a žáky dochází. Učitelé by přitom ideálně neměli mít autonomii a pravomoci pouze na úrovni tř́idy (nap̌r. ve výběru učebnic, témat, materiálů, výukových postupů), ale také i na úrovni instituce školy. Posledním faktorem na úrovni školy, jejž v návaznosti na zahraniční šetření zmíníme, je vztah učitelů a rodičů jejich žáků. Jak v této souvislosti podotýká Winograd (2002, s. 359), absentující podpora rodičů se do mocenského uspořádání ve třídě silně promítá a není nic, co by je mohlo narušit více, než „rodičovský cynismus vztahující se ke škole“.

Za hranicemi školy se pak nacházejí podmínky vzdělávací politiky, které zahrnují organizaci školního vzdělávání v širším smyslu: vzdělávací programy,

$6 \quad$ Př́kladem je student Cody. Cody o víkendech pracoval na farmě a chodil na lov. Jednou v pondělí zapomněl svůj lovecký nůž v batohu a přinesl ho do školy. Protože školní řád zakazuje nošení zbraní do školy, byl Cody vyloučen. Toto vyloučení vnímal jako nespravedlivé, protože nůž do školy nepřinesl záměrně (Hendrickson, 2012). 
kurikulum, systém hodnocení atd. Tyto struktury determinují roli učitele a podobu vyučovacího procesu. Podle Cumminse (2009) je však stěžejní mikrorovina, tedy interakce učitele se žákem, kde se mocenské vztahy utvářejí a sdílejí. Přestože tedy učitele limitují mocenské vztahy na celospolečenské úrovni, naplnění role, kterou v mocenských vztazích zastává ve školní třídě, je také výsledkem jeho individuální volby způsoby interakce se žáky.

Skrze koncept moci můžeme sledovat mocenské vztahy na různých úrovních - mezi učiteli a žáky; mezi žáky navzájem; mezi žáky/učiteli a školou jako sociální institucí atd. (Jacobs, 2012). Jako stěžejní se nám jeví první rovina každodenního vyjednávání a uplatňování moci ve školní tř́dě. Náš výzkum je proto zaměřen na moc v interakci učitele a žáků, na kterou nahlédneme skrze roli učitele. Je třeba podtrhnout, že i když hovoříme o moci učitele, nepojímáme moc jako jeho dispozici. Tento fenomén chápeme jako fenomén reciproční a porozumění mocenským vztahům stavíme na tom, jak mocenskou situaci vnímají všechny zúčastněné strany. Protože předložený teoretický rámec vychází z množství zahraničních zdrojů, než přejdeme k vymezení moci v našem výzkumu, dovolíme si shrnout stav zakotvení tohoto konceptu v české pedagogické vědě.

\subsection{Koncept moci v českém pedagogickém prostředí}

V českém pedagogickém prostředí problematika moci jakožto konceptu interaktivní povahy není př́liš ukotvena a pozornost je průběžně věnována spíše prŕibuzným konceptům. Setkáváme se tak s teoretickými pracemi, které problematiku vztahů mezi učiteli a žáky nahližejí ze strany učitele a jeho působení a popisují jeho autoritu (Pařízek, 1988; Vališová \& Kasíková, 2011) či autoritativnost (Čáp \& Mareš, 2001), nebo ze strany žáků a jejich chování (např. jejich kázeň a zejména nekázeň, Bendl, 2001; př́padně disciplína, srov. Malach, 2007), a to bez jednoznačného terminologického vymezení. Výjimku mezi teoretickými pracemi tvoří zejména práce Pražské skupiny školní etnografie, mezi nimiž můžeme jmenovat např. príspěvek Viktorové (1995) vypovídající o autoritě v kontextu př́ípravy na profesi učitele, či dotazníkové šetření Novotného (1997) zabývajícím se autoritářstvím učitele.

Př́mo s konceptem moci se setkáváme taktéž, avšak spíše sporadicky - např. v metodických pracích Vališové (1998), která jej nicméně chápe synonymně s pojmem autorita, nebo u Maňáka (2003), jenž však moci přisuzuje primárně negativní konotace. S empirickým uchopením fenoménu (v jeho neutrálním pojetí, ve shodě se zahraniční literaturou) se setkáváme ojediněle, např́klad v empirické stati Kučery (1995), který o moci hyperbolicky hovoř́ jako o možnosti někomu něco vnucovat (což nemusí být chápáno negativně, mủže jít o dobré rady a poznatky), ve studiích Makovské pojednávajících o zobrazení moci v žákovských príbězích (2010) a žákovských technikách změny chování (2011) a zejména v již zmíněné studii Šed’ové (2011), jež mocenské vztahy dává do souvislosti se 
strukturováním výukové komunikace a definuje čtyři mody tzv. mocenských konstelací. $\mathrm{Z}$ důvodu poměrně krátké historie konceptu moci a převažujícího užívání konceptu autority v českém pedagogickém prostředí jsme se proto $\mathrm{v}$ dalším kroku zaměřili na vztah autority a moci. Nabízí se dokonce otázka, zda moc není jen „módním“ označením autority.

\subsection{Je moc převlečená autorita?}

$\mathrm{V}$ této kapitole vymezíme vztah pojmů moc a autorita. Oba pojmy k sobě mají blízko, nejsou však synonymní ani se nemohou vzájemně nahradit. Při vymezení autority se můžeme opř́t o definici Webera. Podle něho je autorita vztahem, ve kterém se jedna osoba (nebo skupina osob) řídí a bez zpochybnění akceptuje príkazy jiné osoby (nebo skupiny osob). Autorita je pojímána jako asymetrický vztah, kde jeden uděluje rozkazy a druhý je následuje (Pace \& Hemmings, 2007). Pohled Webera se promítl i do české pedagogické vědy. Vališová (1998) popisuje autoritu jako sociální vztah mezi nositelem autority a př́jemcem autority. K nositeli autority vztahuje dominanci vyznačující se sklonem autoritu vytvářet a k příjemci autority submisivitu vyznačující se spíše sklonem autoritu přijímat. Jinými slovy, autorita vytváří vztah nadřízenosti a podřízenosti (Vališová \& Kasíková, 2011). Se slovem autorita se nejčastěji pojí obrázek učitele ve tř́́dě (Amit \& Fried, 2005). Autoritu přiřazujeme v pedagogickém procesu k tomu $\mathrm{z}$ aktérů, který uděluje rozkazy, zatímco $\mathrm{k}$ tomu, jenž je přijímá, vztahujeme pojmy poslušnost a kázeň. Kázeň tedy chápeme jako vědomé dodržování zadaných nebo dobrovolně přijatých norem chování (Bendl, 2004; Střelec, 1998).

Přestože autorita i moc mají některé podobné charakteristiky (zejména vztahovost), nelze tyto pojmy zaměňovat. Autorita a kázeň jsou navázány na konkrétní aktéry ve tř́dě: autorita na učitele, kázeň na žáky. Oproti tomu moc ve školní třídě můžeme připsat jak učiteli, tak i žákům. Moc je fenoménem, který se může ve tř́́dě přelévat, může cirkulovat mezi žáky a učitelem i mezi žáky navzájem. Je to jev dynamické povahy, nebot mocenské vztahy se ve školní třídě neustále rekonstruují.

Moc je pro nás stejně důležitým konceptem, jako je autorita a kázeň. Přestože se autorita zdánlivě může těšit menší oblibě sociálních vědců $\mathrm{v}$ současnosti, je pro řízení učebního procesu bezpodmínečným jevem (Pace \& Hemmings, 2006). Autoritu a kázeň nelze studovat izolovaně. Autorita tvoří s kázní spojitou nádobu, nebot kázeň předpokládá autoritu (Vališová, 1998) a naopak. Tyto dvě strany však pro nás stále nejsou komplexní. Pro komplexnost v pohledu na tyto jevy edukační reality nám slouží koncept moci, který je pomyslným jazýčkem vah mezi autoritou a kázní.

Ke konceptu moci se nekloníme z důvodu kritiky konceptu autority, jak to dělají např́íklad antiautoritativní směry, kritičtí myslitelé a představitelé postmoderních 
koncepcí ${ }^{7}$, nýbrž z metodologických důvodů. Koncept moci dokáže zachytit dynamiku jevů ve školní tř́idě, kterou zkoumáme. Mocí tedy autoritu nenahrazujeme, nýbrž doplňujeme triádu autorita - moc - kázeň (obrázek 1), jež dle našeho názoru lépe slouží porozumění jevưm ve školní třídě. Navazujeme také na tradici provedených výzkumů moci ve školní třídě uvedených výše.

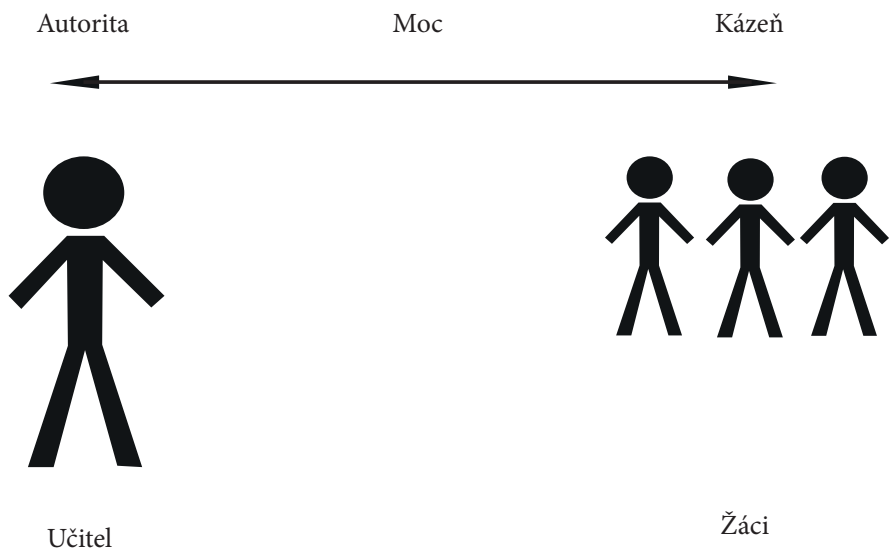

Obrázek 1. Triáda autorita - moc - kázeň.

Moc je tedy jednou ze stránek autority učitele (Middendorf \& McNary, 2011), ale může být i prostředkem sloužícím žákům jak k plnění edukačních cílů (viz Šedová, 2011), tak i ke konfrontaci těchto cílů. Stejně jako může učitel moc ve škole využívat i zneužívat, mohou tak činit i žáci. Pokud žáci moc zneužívají, většinou se jedná o rušivé chování, za kterým stojí snaha získat mocenský vliv nad učitelem (Gootman, 1997). Triáda autorita - moc - kázeň slouží k porozumění

$7 \quad$ Kritiku pojmu autorita lze sledovat již od 60. let 20. století. Nejradikálnějším z antiautoritativních směrů je zřejmě antipedagogika, která vytýká vzdělávání pedagogický totalitarismus, v jehož rámci dospělí ovládají svobodu dětí (Prokop, 2005). Také kritičtí myslitelé na koncept autority učitele zaútočili s cílem osvobodit žáky utlačované autoritou učitele v procesu vzdělávání. V roce 1964 publikoval Pierre Bourdieu spolu s Jean-Claudem Passeronem sociologickou studii studentů, učitelů a osvojování kultury (Prokop, 2005). Bourdieu a Passeron odkrývají učitelovu autoritu jako platformu, jež slouží reprodukci sociálních nerovností a brání vzestupné sociální mobilitě (Gale, 1996). Kritické teorie byly hloubkově rozpracovány v kritické pedagogice. Průkopník kritické pedagogiky Paulo Freire shrnul útlak učitelem tím, že učitel zaměňuje autoritu vědění s autoritou vztažnou k učitelské profesi, kterou tak staví proti svobodě studentů (Freire, 2000). Dle Freireho útlak učitelem jako autoritou spočívá v tom, že prosazuje svoje volby, je tím, kdo volí obsah vzdělávacího programu, jemuž se studenti podřizují, a učí nedialogicky, tedy tak, že ho studenti poslouchají. Soudobí kritičtí pedagogové jako Giroux, McLaren, Kanpol, Steinberg nebo Cho staví oproti autoritativním a hierarchickým vztahům demokratické postupy zdůrazňující zplnomocnění studentů. $\mathrm{V}$ postmoderních směrech je autorita rekonstruována jako jev dialogický, participativní, pluralistický a antihierarchický. Postmodernisté vyzývají učitele, aby se naučili tradiční autoritu dekonstruovat a porozumět tomu, jak je konstruována (Pace \& Hemmings, 2007). 
těmto jevům ve tř́iě. Zatímco autorita a kázeň jsou v české pedagogické vědě precizně definovány, u moci tomu tak není. Nyní se tedy zaměříme na tři charakteristiky, kterými se moc odlišuje od pojmu autorita, a poté ji vymezíme pro účely našeho výzkumu.

\subsubsection{Cirkularita moci}

Cirkularita moci předznamenává, že moc je ve školních třídách všudypřítomná a nepřetržitě se pohybuje mezi učitelem a žáky i žáky navzájem. Moc se ze třídy nikdy neztrácí. Spíše než aby však byla někým konstantně vlastněna, od situace k situaci cirkuluje po třídě (Buzzelli \& Johnston, 2001, s. 875). Když tedy např́iklad učitelé hovoři o ztrátě kontroly, neznamená to, že by se moc ze třídy vytrácela a mizela, ale že se modifikuje takovým zpo̊sobem, že mohou navrch získávat žáci (Aultman, William-Johnson, \& Schutz, 2009, s. 364).

Obdobné uspořádání přitom nelze automaticky nahlížet jako nefunkční. Tuto skutečnost vhodně ilustruje Winograd (2002), který uvádí situaci, kdy svým žákům na prvním stupni řekl, že až úspěšně vypočítají řešení dvou matematických př́kladů, mohou si kreslit. Ve chvíli, kdy do konce hodiny zbývalo pouze několik minut a většina žáků si již v lavici hrála, přišla za ním žákyně, která byla na matematiku nejslabší, přinesla mu sešit $s$ jedním správně vyřešeným př́ikladem a zeptala se, zda by si taktéž mohla chvíli kreslit. Vzhledem k tomu, že autor věděl, že v rámci svých možností odvedla žákyně více práce, než dalo řadě jejích spolužáků vypočítat př́ílady oba dva, ustoupil jejím požadavkům, čímž bylo jeho původní zadání modifikováno. Uspořádání vyučovací situace tak, že rozhodovací pravomoci jsou sdíleny, tedy pro učitele neznamená cíleně abdikovat (Schulz \& Oyler, 2006).

Tuto charakteristiku moci pravděpodobně nejvýstižněji charakterizuje Foucault (1978, s. 2; podobně také Oyler, 1996): „Moc není pevná komodita, kterou někdo vlastní, může ji rozdělit jako koláč a sdílet, ale je to volně plovoucí, rozptýlená a produktivní síla, která tvaruje nás samotné i naše vztahy. $S$ tímto vědomím již nemáme mocné učitele a bezmocné žáky, ale mnohočetné, všudypřítomné mocenské vztahy, kde se různá míra moci může týkat jak žáků, tak i učitelů." Pokud ve školní třídě učitel přispěje ke změně uspořádání mocenských vztahů tak, aby do nich mohli více intervenovat žáci, nemusí to pouze automaticky znamenat, že pozice učitele je tím oslabena. Sdílením moci se žáky může být pozice učitele naopak upevněna.

\subsubsection{Situačnost moci}

S cirkularitou moci úzce souvisí její situačnost, z níž vyplývá, že uspořádání mocenských vztahů se neustále proměňuje např́ić situacemi a jejich jednotlivými 
rovinami (Jacobs, 2012; Hawes Denos, 2003). V rámci jedné vyučovací hodiny tak dochází $\mathrm{k}$ opakovanému (re)konstruování mocenského uspořádání mezi učiteli a žáky (jako jednotlivci i jako skupinou) např́č jednotlivými situacemi a aktivitami, $v$ prostorovém kontextu školní tř́dy a politicko-ekonomickém kontextu učitelů a školní lokality (Winograd, 2002, s. 344). Přestože učitelé se svými žáky často dospívají $\mathrm{k}$ jednomu typu uspořádání, který může být pro jejich vztah určující (srov. vymezené mocenské konstelace Šed’ové, 2011), neznamená to, že by se celá vyučovací hodina odehrávala právě v tomto modu.

V souvislosti s mocí jakožto situačním fenoménem můžeme ilustrovat, proč moc nelze vymezit unilaterálně a chápat ji jako vlastnost jednotlivce. Pokud by totiž moc byla vlastností jednotlivce či skupiny, nebylo by možné, aby docházelo k modifikaci mocenských vztahů např́klad vlivem změny prostoru. Namísto toho by existovala pouze fixní struktura vzájemných pravidel. Tomu však odporuje například výzkum Kenkmannové (2011), jenž dokládá, jak může mocenské uspořádání proměnit např́iklad změna prostoru, $v$ němž se výuka odehrává. Autorka na základě svého empirického šetření ukazuje, že ve chvíli, kdy se vysokoškolská výuka přesune do prostoru muzea, dochází také ke změnám v mocenském uspořádání. Zatímco učitel působil ve výzkumu autorky doposud jako ten, kdo byl ve výukovém prostoru „doma“, vítal studenty ${ }^{8} \mathrm{v}$ prostoru učebny a zasahoval do toho, co se bude ve které její části odehrávat, v muzeu dochází ke společnému vytváření výukového prostoru, nebot všichni přicházejí zvnějšku jakožto cizí. V důsledku toho dochází k hledání nových teritorií i prostoru pro společnou i individuální práci, novému ustavování pravidel a dočasných norem.

Uvažování o roli fyzického prostoru školní třídy $\mathrm{v}$ kontextu mocenského uspořádání mezi učitelem a žáky se opírá o tradiční jména. Jak nastiňuje Goffman (1999), spojení mezi prostorem a mocí se objevuje již dlouho, což platí také ve školní tř̌́dě. Již tím, kde učitel stojí, zaujímá určité mocenské postavení, nebot’ tím určuje, ke komu mluví, na koho se dívá apod. (srov. Bradová, 2013). To rezonuje s Foucaultovou tezí (1978), že využití prostoru není nikdy neutrální.

Situačnost moci pochopitelně nesouvisí pouze $s$ uspořádáním výukového prostoru a rozestavěním jednotlivých aktérů $\mathrm{v}$ něm. Stejně tak je patrná v tom, jak se mocenské uspořádání proměňuje $\mathrm{v}$ závislosti na aktivitě, která ve třídě probíhá, fázi hodiny (srov. Winograd, 2002), jejím zařazení v rozvrhu, dobou ve školním roce atd.

\subsubsection{Reciprocita moci}

Do třetice koncept moci definujeme ve smyslu recipročního vztahu, v jehož rámci dochází ke vzájemnému ovlivňování postojů, hodnot a jednání (srov. např̀

8 Označení studenti je systematicky používáno pro studenty vysokých škol či univerzit. V př́padě, kdy pojednáváme o prostředí základních či středních škol, pak vždy hovoříme o žácích. 
McCroskey, Richmond, \& McCroskey, 2006; Moscovici, 2007). K tomuto procesu přitom nedochází na základě toho, že jedna ze zúčastněných stran disponuje určitými zdroji, na jejichž základě může ovlivňovat druhou ze zúčastněných stran, ale tím, že je takto vnímána. Přestože se tedy poměrně často hovoří například o moci učitele, nejedná se o jeho dispozici, jak by mohlo z daného sousloví mylně vyplývat, ale o percepci ze strany toho, kdo je s ním ve vztahu, například žáků nebo rodičů. Na tomto principu jsou vystavěna také nejrůznější dotazníková šetření, jež moc učitele měří (srov. Elias, 2007; French \& Raven, 1959; Schrodt, Witt, \& Turman, 2007). Pokud si tuto relaci ukážeme na př́́kladu legitimní moci (moci přisouzené na základě sociální role učitele), znamená to, že zkoumáme nikoli to, nakolik učitelé nedisponují legitimní mocí, ale do jaké míry mají jejich žáci zvnitřnělé hodnoty, které jim diktují, že učitelé mají legitimní právo dávat žákům určité instrukce (srov. Jamieson \& Thomas, 1974). K vymezení moci proto přistupujeme ve smyslu působení v rámci recipročního vztahu (srov. Goffman, 1999; Woods, 1983, Kaščák, 2006) nebo „silového pol“ (Kaščák, 2008, s. 128), z interakcionalistické perspektivy (Staton, 1992).

Z reciprocity moci vyplývá, že pro porozumění mocenským vztahům je nutné porozumět tomu, jak situaci vnímají všechny zúčastněné strany. Ani při zúžené optice, kdy dochází ke zkoumání pouze jedné z nastíněných úrovní, přitom nelze zcela opomenout ostatní úrovně, na kterých se mocenské vztahy utvářejí a modifikují.

\subsubsection{Moc jako téma výzkumu}

Moc ve školní třídě můžeme na základě teoretické analýzy definovat jako kontextově vázané uspořádání výukové situace, v jehož rámci učitel i žáci (jakožto jednotlivci i skupina) vzájemně ovlivňují své postoje, hodnoty a jednání. Na základě cirkularity moci můžeme sledovat, jak se podoba mocenského uspořádání modifikuje mezi učitelem a kolektivem žáků, mezi učitelem a jednotlivými žáky i mezi žáky navzájem. K tomuto ovlivňování přitom dochází v závislosti na tom, jakým způsobem do mocenského uspořádání jednotliví aktéŕi intervenují a jak jsou v danou chvíli vnímáni ostatními ( $\mathrm{v}$ čemž spočívá podstata reciprocity moci). $\mathrm{V}$ obou těchto bodech můžeme hovořit o vertikální modifikaci mocenského uspořádání. Situačnost moci pak přispívá $k$ tomu, že se uspořádání mění $\mathrm{v}$ čase (dochází $\mathrm{k}$ horizontální modifikaci), v závislosti na jednotlivých mikrosituacích světa školní třídy a jeho okolí.

Na základě výše uvedeného chápeme moc ve školní třídě ve třech rovinách: 1) potenciální moc - moc jako potenciál, pouhá možnost jednat určitým způsobem, 2) uskutečněná moc - moc jako skutečně uplatňované aktuální jednání, 3) stabilizovaná moc - moc jako dlouhodobý důsledek skutečně uplatňovaného jednání. Potenciální moc je východiskem pro naše uvažování, nebot moc chápeme jako možnost ovlivňovat. Ve výzkumu se ale zaměřujeme zejména 
na uskutečněnou moc, která vychází z tohoto potenciálu, ale může být ovlivněna dalšími faktory (např́klad neočekávanou situací, do níž se učitel dostane). Opakující se podoby uskutečňované moci mohou vést k její stabilizaci. Důsledky a efekty stabilizované moci se v tomto výzkumu nezabýváme, nebot výzkum by musel mít v takovém př́padě dlouhodobý charakter.

Výzkum orientovaný na problematiku moci je $\mathrm{v}$ zahraničí etablovanou součástí pedagogických věd. Iniciačním bodem výzkumných studií se stala tradiční typologie moci Frenche a Ravena (1959), která je nejčastěji sledována u učitelů (srov. Elias, 2007; Schrodt, Witt, \& Turman, 2007). Tuto typologii přejímáme i v našem výzkumu a zaměřujeme se na báze moci učitele.

\subsection{Moc jako vícedimenzionální fenomén}

Výzkum moci učitele se tradičně zaměřuje na oblasti, $\mathrm{v}$ nichž učitel moc uplatňuje, a které bývají označovány jako báze moci. Báze moci jsou dle Frenche a Ravena (1959) rozlišovány podle principu, na němž je moc vystavěna. Tito autoři $\mathrm{v}$ rámci uvažování o moci rozlišili nejprve pět základních mocenských bází, jež označili jakožto moc legitimní, donucovací, odměňovací, expertní a referenční, kdy učitel může uplatnit ve vztahu k žákům jednu či více z těchto bází.

Stále platí, že moc je vztahovou záležitostí. Zahrnuje vztah mezi tím, kdo moc uplatňuje, a tím, kdo ji přijímá. Mocenské báze proto vždy fungují tak, že popisují, jaké vlastnosti přisuzuje žák učiteli (srov. Jamieson \& Thomas, 1974). Přestože tedy hovoříme o moci učitele, nejedná se o jeho dispozici, jak by mohlo z daného sousloví vyplývat, ale o percepci a hodnocení ze strany toho, kdo s ním vstupuje do vztahu, např́íklad žáků nebo rodičů (Šalamounová, Bradová, \& Lojdová, 2014). Napríklad pokud žáci nebudou vnímat a akceptovat učitelovu legitimní moc, těžko může učitel tuto moc uplatnit. Ilustrovat to může hypotetický př́ílad, kdy by do třídy přišel vyučovat neznámý člověk z ulice. Žáci by pravděpodobně neplnili jeho požadavky, protože by tato osoba nedisponovala legitimní mocí spojenou s rolí učitele. Tento př́klad se nemusí přitom jevit jako utopický, jak se na první pohled může zdát. Do podobné situace se mohou dostat studenti učitelství na praxi, které uvádějící učitel nepředstaví žákům a nepřiipíše jím tím formální autoritu. Zatímco učitel disponuje formální autoritou vyplývající už z jeho role, student na praxi ji nemá. Student se tak může dostat až do situace výkonu učitelství bez formální autority. Bez formální autority přitom nemohou studenti uplatňovat moc spojenou s rolí a naplňovat další mocenské báze, byt' by $\mathrm{k}$ tomu měli potenciál. Důsledkem tohoto procesu může být vnímání vlastního selhání $\mathrm{v}$ roli, přestože toto selhání není dáno studentem samotným, nýbrž nefunkčním nastavením role ze strany cvičného učitele (Lojdová, 2014). 


\subsubsection{Legitimní báze moci}

První z bází moci, kterou popíšeme v teorii i ve výzkumu, je moc legitimní. Legitimní moc vypovídá o tom, zda žák předpokládá, že učitel má v závislosti na své profesní roli učitele legitimní právo předepisovat žákovi, jak se má v určité oblasti chovat. Legitimní moc souvisí se sociální rolí učitele, která garantuje (formální) autoritu nad žáky. Tato role je spjata s normou dohližžet na druhé a ovlivňovat je.

Moc legitimní se v tomto kontextu překrývá s mocí sociální (Foucault, 2000), v jejímž rámci je učitel prvkem sociální organizace, skrze nějž prochází moc školy - legitimita sociální moci vyplývá ze samotné role učitele a jeho místa ve struktuře společnosti (Kaščák, 2006). Také Dvořák, Urbánek a Starý upozorňují, že chování škol a učitelů je významně determinováno institucionálním prostř̌edím, přesněji makroprostředím. Pro školu je také typické, že její legitimita stojí a padá s důvěrou, kterou do ní vkládají zřizovatelé a rodiče (Dvořák, Starý, \& Urbánek, 2015). Pol (2007) také zdůrazňuje vztah školy a širšího systému, ve kterém platí vnější pravidla (právní, ekonomická, společensko-politická), která škola musí respektovat. Tyto vnější požadavky ohraničují prostor, v němž se školy pohybují a vymezují tak podobu jejich legitimní moci. Štech a Viktorová (1995) uvádějí aktivní roli instituce školy ve vyjednávání legitimity, kde dochází k hájení vlastní autority, tedy především autority učitelů, jako představitelů instituce, která je definovaná právě přes svůj protějšek, přes klienty, tedy přes žáky a jejich rodiče. Distribuce moci je pak dle autorů chronických rysem institucí typu školy. Všichni aktéŕi školního prostředí musejí obhajovat legitimitu své autority vůči ostatním, vytvářet dohodu vzájemného styku a obnovovat ji. Podle Carlsona (in Dvořák, 2010) jsou školy „ochočenými organizacemi“, jež se neřídí logikou efektivnosti, ale logikou legitimity. Jsou zcela v rukou státu, mimo působení tržních sil (srov. pojetí školy in Pol, 2007). Viktorová (2011) zmiňuje jako důležitý zdroj legitimity školy byrokracii. Ta se realizuje prostřednictvím různých byrokratických úkonů, jež ji stabilizují a legitimizují její smysl a důležitost např́́klad v nejednoznačně definovaném zájmu dětí. Je zajímavé, že žáky jako zdroj legitimity učitele uváděli v dřívějším výzkumu Viktorové (1995) právě studenti učitelství. Pro studenty učitelství je ve vztahu k pravidlům ve škole důležité „vysvětlení, co která pravidla znamenají, a to vysvětlení směřující $\mathrm{k}$ dohodě, $\mathrm{k}$ souhlasu, vyjednaná $\mathrm{v}$ jejich jediné legitimní poloze - se žáky" (Viktorová, 1995, s. 175). Může to souviset i s počáteční fází vývoje učitele, již jsme charakterizovali v první kapitole snahou o blízký vztah studentů učitelství a začínajících učitelů k žákům.

Legitimní moc učitele tedy vychází z makrosociálního prostředí (role učitele ve společnosti), z mikrosociálního prostředí školy (učitel jako představitel organizace a její byrokracie), od aktérů mimo školu (zřizovatelé, rodiče) a v neposlední řadě od žáků. $V$ př́padě studentů učitelství je zřejmé, že jejich postavení ve společnosti a organizaci školy není tak stabilizované jako postavení učitelů. Jsou jim ale propůjčeny byrokratické mechanismy (např́klad zapisování známek 
diskutované v kapitole 4.4). Důležitým zdrojem legitimní moci jsou proto pro studenty učitelství žáci a jejich cviční učitelé, kterým se budeme věnovat důkladněji v kapitole 4.2.

Legitimní moc školy je spojena s její rolí ve společnosti. Vzdělávání nese funkci transmise hodnot a vzorců chování. Díky němu se ve společnosti dosahuje základní sociální konformity. Tuto funkci školy můžeme označit jako konzervační (Ottaway, 1998). Škola je agentem sociální kontroly9 ${ }^{9}$ tedy tím, kdo ovlivňuje chování mladých lidí tak, aby odpovídalo normám ve společnosti. Dvořák (2010) to vystihuje tak, že veřejná škola musí akceptovat prakticky všechny děti ze spádové oblasti, včetně „problémových“, proto je jejím primárním problémem výkon sociální kontroly - dohližzení a sankcionování. Legitimní moc učitele se proto nevztahuje jen k dění ve tř́́dě, ale i dění ve společnosti. Učitelé při výkonu sociální kontroly vystupují jako zástupci veřejných zájmů a legitimního společenského řádu. $\mathrm{K}$ tomu užívají pozitivní a negativní sankce. Dle našich předchozích výzkumů studenti v začátcích své praxe nereflektují, že by mohli být reprezentanty společenského systému a jeho norem, ani nevnímají dilema, zda tento systém podporovat či naopak. Naopak v studentských reflexích vyvstává význam a míra sociální kontroly v mikroprostředí školy (Lojdová, 2014). S legitimní mocí na makroúrovni souvisí i vývoj identity učitele, do něhož se promítá i dění na celospolečenské úrovni, reprezentované např̀ zájmovými skupinami či vládami (viz kapitola 1.2.2). Toto dění mohou vnímat i studenti učitelství, přestože se do něj teprve socializují, a může tak ovlivňovat jejich chápání legitimní moci spojené s rolí učitele.

Legitimní moc školy a učitele mohou žáci přijímat, mohou vůči ní ale také revoltovat. Jak jsme popsali v kapitole 2.2, rezistence je součástí mocenských vztahů. Teorie rezistence ukazují, jak komplexním problémem může nevhodné chování žáků ve školní třídě být, nebot nemusí souviset jen s individuálními zvláštnostmi žáků či s aktuálním děním ve třídě, ale i s legitimní mocí instituce školy ve společnosti. V makrosociálním pohledu zaznívají v interpretaci rezistentního chování kritické pohledy na reprodukci sociální nerovnosti ve škole. Rezistentní teorie (Giroux, 2001; McLaren, 1985; McLaren, 2006) ukazují, jak žáci vzdorují dominantní kultuře a také jak interagují s reprodukcí norem ve škole (Dickar, 2008). Oproti deterministickým reprodukčním teoriím (Bourdieu, 1977) tak pojímají žáky jako aktivní aktéry, kteří skrze rezistenci mohou ovlivnit opresivní struktury.

Legitimní báze moci je vícevrstevnatým fenoménem, jenž je také úzce spjat $s$ dalšími dvěma bázemi moci - donucovací a odměňovací. Donucování i odměňování totiž předpokládá legitimitu aktéra, který tak činí.

9 Sociální kontrola je souhrnný termín označující všechny mechanismy, které mají zajištovat řád, stabilitu a dodržování norem (Innes, 2003). 


\subsubsection{Donucovací báze moci}

Donucovací mocenská báze ${ }^{10}$ je založena na skutečnosti, že žák vnímá učitele jakožto někoho, kdo jej může potrestat (přísně se podívat, napomenout, dát špatnou známku apod.). Mocenská báze tedy nestojí na tom, že učitel je schopen potrestat žáka, ale že jej žák tímto způsobem vnímá, což je ve shodě s reciproční povahou fenoménu, o němž pojednáváme. Naplnění donucovací moci učitele vychází např́klad z žákovy potřeby vyhnout se trestu v různé podobě.

Foucault (2000, s. 255) pod pojmem trest rozumí „vše, co je schopno vyvolat v dětech pocit chyby, jíž se dopustily, vše, čím je lze ponížit, uvést je ve zmatek: jistý chlad, určitá lhostejnost, otázka, ponížení, svržení z určitého postavení“. Foucault (2000) dále rozvíjí ideu trestatelnosti ve škole: ve jménu trestání je užívána celá řada subtilních postupư, od lehkého fyzického trestu po mírná strádání či drobná ponižování. Jde o to, současně učinit trestatelné i nejmenší odchylky v chování (opoždění, absence, přerušení činnosti, nezdvořilost, neposlušnost, „nesprávné“ postoje, nekonformní gesta, nestydatost) a dodat trestní funkci i zdánlivě indiferentním prvkům disciplinárního aparátu: v krajním případě tak může cokoli sloužit k potrestání i toho nejmenšího přestupku, takže každý subjekt se nachází zachycen v trestající-trestatelné univerzalitě. Přestože se Foucaultovo pojetí může jevit jako mírně historizující, užitečné je z hlediska uvažování o škole jako o specifické instituci využívající donucovací moc. Abychom donucování zasadili do kontextu současné české školy, lze zmínit například výzkum Dvořáka. Dvořák (2010, s. 236) uvádí některé pacifikační strategie v české škole, které chápeme jako projevy donucovací moci učitele, nebot představují hrozbu trestu nebo výkon trestu samotný: fyzické přiblížení k žákovi, přesazování žáků, pacifikační strategie neverbální povahy (zvonění na zvoneček, tukání ukazovátkem, pískání na píštalku) a dále pak vyvolávání žáků za trest. Žák, který nedává pozor, je vyvolán, aby odpověděl nebo napsal řešení na tabuli.

Je třeba zmínit, že laickou veřejností a dokonce některými učiteli je používání trestů stále vnímáno jako jeden ze základních způsobů motivace žáků (srov. Mareš, 2013a), takže z tohoto úhlu pohledu se může i využívání donucovací moci učitelem jevit jako stěžejní složka jeho chování. K základním a snadno rozeznatelným formám trestů patří např́klad obava žáků ze špatných známek, z kritiky před třídou, $\mathrm{z}$ nesouhlasných verbálních projevů ze strany učitele či ze spojení těchto projevů s neverbálním vyjádřením „odstupu“ od žáka (zdvižené obočí, „nepř́ijemný“ pohled apod.). Ovšem donucovací moc se může projevovat i způsoby, které mají překvapivě ambivalentní povahu. Nejednoznačnost podoby trestů, jež v některých prŕpadech neplní svoji „donucovaci“ funkci, lze

10 Termín donucovací moc či donucovací báze moci užíváme ve shodě $\mathrm{s}, \mathrm{v}$ české odborné literatuře, zažitým překladem $\mathrm{z}$ anglického coercive, i když jsme si vědomi možných negativních konotací tohoto termínu. $\mathrm{Na}$ tomto místě a také $\mathrm{v}$ kapitole 4.3 se proto naše pojetí donucovací moci pokusíme zpřesnit a zasadit do kontextu prostředí školy. 
dokumentovat např. na situaci začínajícího učitele (tedy i studenta učitelství) ve vztahu $\mathrm{k}$ „neukázněnému“ žákovi ${ }^{11}$ : „učitel se mu snaží ukázat svoji autoritu, napomíná jej, trestá. Stupňující se postihy za nevhodné chování plní funkci jakéhosi oboustranného vymezování pozic. Provokující žák ovšem nemá vůči třídě co ztratit, naopak. Znevažování, trestání ze strany učitele jen upevňuje jeho postavení ve třídě." (Mareš, 2013a, s. 329). Lze ovšem vysledovat i opačné situace, kdy se trestem pro žáka paradoxně stává takové chování učitele, které bychom $\mathrm{v}$ zásadě považovali za odměnu - např́klad pochvala před třídou, jejíž klima lze v pojetí Laška (2004) označit jako motivující k negativnímu školnímu výkonu, může pro konkrétního žáka mít atributy trestu.

Donucovací moc (částečně i ostatní báze moci) bývá ve vztahu k žákům uplatňována ve dvou diskursech, jež můžeme teoreticky vymezit jako didaktický a regulativní (Bernstein, 1996). Didaktický diskurs se týká naplňování didaktických cílů, kdy učitel uplatňuje moc za účelem dosažení těchto cílů. V regulativním diskursu je moc uplatňována za účelem řízení tř́dy (srov. Evertson \& Weinstein, 2006; Lewis, 2008; Shindler, 2010). V tomto kontextu lze využívání donucovací moci částečně chápat také jako mechanismus ukázňování žáků. Někteří autoři upozorňují na nutnost určité míry kázně ve třídě pro vytvoření takového klimatu třídy, ve kterém může učení zdárně probíhat (Lewis, 2001). Je zřejmé, že se oba diskursy v realitě školní tř́ídy vyskytují současně - učitel nějakým způsobem řídí třídu, aby tím mohl naplňovat didaktické cíle. Donucovací moc (stejně jako moc odměňovací) je také postavena na skutečnosti, že ti kdo kontrolují tresty a odměny, mají moc nad těmi, kteří jsou na těchto trestech a odměnách závislí (Molm, 1997). V této kapitole se přikláníme $\mathrm{k}$ interpersonálnímu pojetí donucovací moci, jež zmiňuje právě Molmová $(1990,1997)$, podle které je donucovací moc založena na veškerých interakcích mezi jedinci a je součástí každodenního života, tedy i života a interakcí ve škole.

Logicky je na tomto místě třeba zmínit pojetí, ve němž bývá donucování spojováno s pojmem manipulace. Ta je převážně vnímána negativně jako takový způsob interakce, při kterém se, většinou skrytě, jedinec snaží ostatní donutit $\mathrm{k}$ určitému chování proti jejich vůli a využívá $\mathrm{k}$ tomu často své vyšší mocenské postavení. Manipulace využívaná učitelem tedy patří k nevhodnému užití donucovací moci a bývá spojována s různými manipulativními metodami a strategiemi, jako je nap̌r. vyvolávání pocitu viny u žáků, zkreslování či zatajování informací, vyvolávání nezdravé soutěživosti mezi žáky či časté změny pravidel fungování třídy, s cílem přesvědčit žáky, že pouze učitel vše zná (lze uvažovat o nevhodně použité moci expertní) a má nad nimi neomezenou moc (srov. Wróbel, 2008)12.

11 Tato situace zároveň může dokumentovat fakt „vyjednávání“ moci, který zmiňujeme v kapitole 2.

12 V psychologii bývá také většinou rozlišováno mezi manipulací a persuazí (přesvědčováním) - tomuto tématu se budeme podrobněji věnovat v kapitole 4.3.1. 


\subsubsection{Odměňovací báze moci}

Odměňovací mocenská báze učitele (v logice shodné s vymezením ostatních bází moci) vyjadřuje, že žák k učiteli přistupuje jako k někomu, kdo je schopen jej odměnit (French \& Raven, 1959), což zahrnuje také to, že odměna musí být pro žáky relevantní. Odměňovací moc je postavena na skutečnosti, že ti, kdo kontrolují odměny, mají moc nad těmi, kteř́ jsou na těchto odměnách závislí, podobně jako u moci donucovací prostřednictvím trestů (Molm, 1997). Ve školním prostředí se však přirozeně nejedná jen o učitele jako aktéra, který disponuje odměňovací mocí, ale také o žáky, kteří mohou jistým způsobem odměňovat učitele či sebe mezi sebou navzájem. Žáci mohou učitele odměnit např́ílad tak, že se přihlásí a pomohou mu, když dlouho nikdo z žáků ve výuce nereaguje na jeho výzvu. Nebo ho mohou odměnit za to, že jim vyšel vstříc s odložením testu, když se nestihli naučit, tím, že se snaží být $v$ hodině soustředěnější a klidnější. Odměňovací bází moci tedy disponují všichni aktéŕi výuky, byt v jiné intenzitě a formách. Z hlediska výuky nás však obvykle primárně zajímá odměňovací moc učitele.

Z hlediska pěti bází moci vycházejících z teorie Frenche a Ravena (1959) je vhodné zmínit specifické postavení odměňovací moci učitele, která je rámována jeho legitimní a referenční mocí (srov. Elias \& Mace, 2005). Např́klad kdyby cizí člověk jen tak přišel do třídy a chtěl žákům dávat jedničky za domácí úkol, asi by se setkal s nedůvěrou žáků, zda je to možné. Učitel může žáky odměňovat právě proto, že mu byla udělena legitimní moc spojená s jeho rolí učitele na dané škole a v dané třídě. Odměňovací moc je také propojená s referenční bází moci. Učitel, kterého žáci vnímají jako referenční osobu, může snáze poskytovat žákům odměny (např. pochvalu), o které žáci stojí a váží si jich. Podobně je tomu u učitele, kterého žáci vnímají jako experta, například když ocení správnou odpověd žáka na komplikovanou otázku ve výuce, může to mít pro žáka velký význam, pokud si učitele jako experta váží.

Odměny mohou nabývat ve školním prostř̌edí nejrůznějších forem, včetně forem specifických právě pro školní prostředí (vyvěšení jmen žáků s nejlepšími studijními výsledky na nástěnku) či forem specifických pro daný věk žáků (napřr. razítka za dobré chování či splnění úkolu na prvním stupni základní školy). Obecně řečeno, odměna může mít povahu nemateriální (pochvala, pochvala před spolužáky) či materiální (možnost účastnit se školního výletu, sladkost). Raven (1992) v rámci svého zpřesňování klasifikace bází moci později odlišil dvě formy odměňovací moci, a to moc osobní a neosobní, odlišované na základě toho, zda odměna má pro žáka osobní význam (viz kap. 2.6.6). V prvním zmíněném př́ípadě žák vnímá učitele jako někoho, kdo je schopen mu poskytnout odměnu, jež pro něj má subjektivní význam spojený s uznáním, o které žák stojí (např́íklad odpovídající typ pochvaly). Odměna pro něj má tedy osobní význam. V případě moci odměňovací neosobní je učitel poskytovatelem odměny neosobní např́íklad dobré známky, která však pro žáka nemá osobní význam. Učitelé či 
celé školy mají v různé míre propracované systémy odměňování žáků, obvykle ve vazbě na jejich motivování.

Odměňovací moc učitele je naplněna snahou žáka získat odměnu v některé $\mathrm{z}$ uvedených forem. Jinak řečeno potenciál odměňovací moci učitele $\mathrm{z}$ hlediska vzdělávacích cílů závisí na tom, do jaké míry se žáci snaží získat např́iklad některou $\mathrm{z}$ výše uvedených forem odměny. V situacích, kdy se učitelé podivují, že jejich odměny nefungují, je možným vysvětlením, že žáci učitelovy odměny za odměny nepovažují. Z hlediska odměňovací moci je tedy třeba, aby učitel věděl, co žáky motivuje v různých oblastech. Výzkumy ukazují (např. Hrabal \& Pavelková, 2010), že se učitelé často neshodují s žáky na tom, co je jejich skutečnou motivací k učení, z čehož plyne, že pak učitelé nejspíše motivují žáky méně adekvátně přislíbí jim odměny, které žáci nevnímají tak silně jako odměny, jak se domnívají učitelé.

$\mathrm{V}$ našem výzkumu budeme odměňovací moc analyzovat především $\mathrm{v}$ jejích formách vyskytujících se ve výuce, a to pomocí videozáznamů a jejich transkriptů, omezeně pak také i v dalším školním kontextu pomocí rozhovorů se studenty učitelství na praxích $\mathrm{v}$ rolích učitele a jejich reflektivních deníků $\mathrm{z}$ této praxe. Na odměňovací moc studenta učitelství nahlédneme také z pohledu žákủ, pomocí dotazníkového šetření. Kapitola 4.4 s výsledky našeho výzkumu týkajících se odměňovací moci tak přináší zjištění, jak odměňovací moc ve výuce uplatňují studenti učitelství na počátku své profesní dráhy učitele a jak jejich odměňovací moc vnímají jejich žáci na druhém stupni základních škol. Odměňovací báze moci studenta učitelství stojí na nepevném základě legitimní, expertní a referenční moci člověka, který se s výukou i s danými žáky, které má učit, setkává z hlediska formální výukové praxe prakticky poprvé a sám sebe ještě nepovažuje často za „hotového učitele“ (srov. kap. 4.5), někdy ani „hotového dospělého“ (viz kap. 1). O jaké rozdíly se u studentů učitelství oproti odměňovací moci učitele jedná, se lze dozvědět v kapitole 4.4 s výsledky z našeho výzkumu.

\subsubsection{Expertní báze moci}

Učitelé (a v našem případě studenti učitelství) disponují mocí expertní, pokud je jejich žáci chápou jako někoho, kdo je v rámci své aktuální činnosti expertem. ${ }^{13}$ V závislosti na tom se pak žáci mohou, nebo naopak cíleně nemusejí chovat ve shodě s tím, co od nich učitel či praktikující student očekává. $Z$ důvodů této polarity v chování žákủ byla expertní báze moci v pozdějších typologiích rozdělena na expertní moc pozitivní a negativní. V prvním př́ípadě si žáci myslí, že

13 Například Ericsson (2006, s. 3) definuje experta mimo jiné jako spolehlivý zdroj informací. V návaznosti na to lze jako součást expertní mocenské báze ustavit také bázi informační, kterou French a Raven (1959) samostatně představili v první revidované verzi své taxonomie mocenských bází. Její princip je založen na tom, že jedna osoba (například žáci) přičítá druhé osobě (například učiteli či studentovi učitelství) informace, které považuje za hodnotné. 
učitel je opravdovým mistrem svého řemesla, tedy tzv. expertem, a proto se chovají ve shodě $\mathrm{s}$ tím, co $\mathrm{z}$ jeho strany považují za žádoucí. $\mathrm{V}$ případě mocenských vztahů fungujících na principu negativní expertní báze se naopak žáci domnívají, že učitele za experta rozhodně nelze považovat, a proto konají pravý opak toho, co se od nich dle jejich názoru očekává. Situace přitom může být nastavena i obráceně. Učitel může žáky v určitém ohledu považovat za experty a podle toho se k nim (at už k jednotlivcům, či celé tř́ídě) chovat (možným obsahem může být např́klad používání technologií apod.), nebo také naopak.

$\mathrm{Na}$ místě je dozajista otázka, kdo se vlastně skrývá pod označením expert a jaké charakteristiky lze expertovi přičíst. Jak uvádí Píšová se spoluautory (2013, s. 11), expert bývá často definován prostř̌ednictvím tzv. relativních prŕstupư jako protipól k učiteli, který se nachází ve stádiu začátečníka či tzv. novice a ve srovnání s nímž dosahuje vynikajících výkonů. V tomto pojetí se tedy jedná o osobu, která se své činnosti dlouhodobě věnuje a disponuje značnými zkušenostmi, jež z ní činí experta (viz Ericson, 2006, s. 3). S tím, že cvičení dělá mistra, a proto také zkušenosti vytvářejí experta, dozajista nelze zcela polemizovat (o životních drahách učitelů a událostech, díky nimž se postupně stali učiteli experty, hovoří např. Švaříček, 2009). Pokud bychom se nicméně striktně drželi tohoto pojetí, museli bychom automaticky rezignovat na to, že studentům učitelství, kteří doposud stojí před startovní čárou své profesní dráhy, lze status experta přiznat. Vzhledem k tomu, že se jedná o dva póly jedné škály, nemohou být studenti učitelství jakožto úplní začátečníci nikdy současně experty. Dlouhodobé setrvání v činnosti navíc ještě samo o sobě není zárukou úspěchu, na což poukazuje naprŕklad Hattie (2003) s tím, že ani to, že je učitel zkušený, nikterak negarantuje, že jej lze považovat za experta. Může se naopak jednat o zkušeného ne-experta (Píšová, 2013, s. 20).

V druhém možném pojetí je expert rozpoznán a definován prostřednictvím svých vlastností, vědomostí a dovedností, na základě nichž je s to podávat excelentní reprodukovatelný výkon (Ericson, 2006, s. 3). Ty nejdůležitější charakteristiky expertů $\mathrm{v}$ oboru učitelství uvádí na základě svých metaanalýz například Hattie (2003), který hovoří zejména o schopnosti řídit žákovské učení, monitorovat je a poskytovat žákům zpětnou vazbu, schopnosti ovlivnit výsledky žákovského učení, a schopnosti rozpoznat nejrůznější situace, které ve třídě mohou nastat, a optimálně jim přizpo̊sobit své jednání. V tomto pojetí je tedy expertnost učitele determinována kvalitou jeho výuky, a expertem se tak může stát i učitel, jehož profesní dráha není z nejdelších. Nakolik může být expertní moc přisouzena také studentům učitelství, jejichž profesní dráha se teprve začíná odvíjet, a jaké indikátory v tom hrají roli, prozatím zůstává nezodpovězenou otázkou, a proto se jí věnujeme v kapitole 4.5 . 


\subsubsection{Referenční báze moci}

Referenční mocenská báze je vystavěna na tom, že žák vnímá učitele jako někoho, kdo je mu blízký, s kým má hodně společného a komu by se prŕípadně chtěl podobat. Žák tedy naplňuje učitelovu moc proto, že se s ním identifikuje nebo k němu má pozitivní vztah. French a Raven (1959) v původním pojetí zdůrazňovali právě pocit jednoty s někým, koho považujeme za svůj ideál, touhu po takové identitě, tedy aspekt identifikace. V tomto pojetí jsou tedy sami žáci nositeli motivu přizpůsobit se učiteli nebo jeho obrazu, modifikovat své chování tak, aby se mu přibližili. Takto pojatá referenční moc má mnoho společného např́klad s koncepcí konformity v reakci na požadavky učitele (Hammersley \& Woods, 1984), kdy žáci „nadšeně souhlasí s cíli učitele“, s fenoménem „zobání z ruky“ (Šed’ová, 2011) nebo s populárním pojetím „přirozené autority“ učitele.

Referenční báze se však neopírá výhradně o konformitu žáků s (atraktivním) obrazem učitelů/učitelek, $s$ jejich požadavky nebo cíli. Nepochybně předpokládá i určité kvality učitelů nebo aktivity z jejich strany, které referenční působení vyvolávají nebo podporují. Jednou z podob referenční moci může být moc „charismatická“, založená na mimořádném, avšak ne nutně plně reflektovaném působení učitele, důležitým aspektem referenční báze moci může být ale samotný lidský vztah mezi učitelem a žáky. Učitel tak není jen „charismatický“ nebo „hodný následování“, ale v souladu s Deweyho (1936) pojetím jde o učitele alive, živého „V plnosti svých mentálních, fyzických, emočních a vztahových zdrojů (dle Píšová et al., 2013, s. 39) - tato charakteristika se pak může ve vnímání žáků odrážet jako „je to nejen učitel, ale i člověk“. Recipročně jsou jako lidské bytosti vnímáni i žáci za strany učitele, což se projevuje především v povaze komunikace. O referenční moci dvojnásob platí, že „způsob, jakým učitel komunikuje se svými studenty, pak z větší části determinuje typ a rozsah moci..." (McCroskey \& Richmond, 1983, s. 175).

$\mathrm{V}$ „živé“ komunikaci učitelů a žáků má kromě konformity své místo i „cirkulace moci“, kdy žáci sdílejí s učitelem cíle, avšak učitel přitom slevuje (tř̌eba i částečně, na určitou dobu apod.) ze své dominance ve prospěch žáků (Šed’ová, 2011). Spíše než na silově mocenském pojetí moci jako „pravděpodobnosti, že jeden aktér sociálního vztahu bude v pozici, kde prosadí svoji vůli i přes rezistenci druhé strany," (Weber, 1998; viz též kap. 2.2 a 2.4) staví na principech vyjednávání a hledání cesty $\mathrm{k}$ formálním či neformálním kontraktům. Nepředpokládá totiž rozpor ve vůli aktérů, ale naopak jejich souhru, prrítomnost rezistence je typická pouze pro negativní pól této báze moci. Soulad se také nemusí výhradně týkat cílů a jejich přejímání nebo sdílení, může být cílem (a důležitým motivem) sám o sobě, zahrnuje reflexi procesủ, které se při učení zapojují (Píšová et al., 2013), a respekt $\mathrm{k}$ nim.

Pro užší (identifikace) i širší (integrativní komunikace) pojetí referenční báze moci platí, že je bází „měkkou“ (Erchul et al., 2001; Erchul, Raven, \& Ray, 2001). 
Nemusí být reflektovaná, člověk si není vždy vědom referenčního vlivu na sebe ani toho, že referenční mocí disponuje. Pro výzkumnou praxi plyne z tohoto pojetí fakt, že se jedná o bázi velmi nesnadno uchopitelnou, nemůžeme se plně opřít o jednoduchou definici odpovídajících projevů. Nelze ani předpokládat nezávislost na ostatních bázích moci - naopak, právě v tomto př́padě je patrné, že se jedná o jednu z řady „bázi“, nikoli diskrétních dimenzí. Referenční pozici spíše získá někdo, kdo současně mistrně zvládá některý z dalších způsobů uplatňování moci: působí jako expert, je schopen dobře nastavit legitimní pravidla, spravedlivě hodnotí a efektivně odměňuje. Analogicky nepřiměřenost v nastolování moci u některé z dalších bází může mít devastující vliv na referenční bázi moci: selhání $\mathrm{v}$ roli experta, nepřiměřené legitimní nároky, nedostatky ve zpětné vazbě žákům i nezvládnuté incidenty mohou ovlivnit i pozici učitele jako referenční figury.

Ve výzkumu (viz kap. 4) se kromě tendence k identifikaci s učitelem/učitelkou jako vzorem zaměřujeme na obecnější pocit sounáležitosti, sounáležitost specifickou vzhledem k věku a pozici, názorový soulad, kvalitu interakce iniciované učitelem/učitelkou, věrohodnost a subjektivní význam sdělení a na neformální či osobní rozměr vztahu mezi učitelem/učitelkou a žáky. Pozornost věnujeme otázce hranic, práce s motivací a emocemi i specifikům situace začínajících učitelů a zvlášt studentů učitelství na praxi.

\subsubsection{Vývoj konceptu bází moci}

Uvedená typologie bází moci byla Frenchem a Ravenem opakovaně revidována a modifikována - poprvé již v roce 1965 (Raven, 1965), kdy byla k původním pěti bázím přidána moc informační. Její princip je podle autora založen na tom, že učitel z pohledu žáka disponuje informacemi, které jsou pro žáka hodnotné. Sám Raven o řadu let později $(1992,1993)$ typologii výrazně rozšiŕil, a to z šesti na čtrnáct bází. Přehled dílčích bází včetně originálního označení v angličtině přinášíme v tabulce 1 .

Tabulka 1

Dílči báze moci v pozdějších typologiích Ravena (1992, 1993)

\begin{tabular}{ll}
\hline Hlavní báze moci & Dílčí báze moci \\
\hline Legitimní moc & Legitimní moc vyplývající z toho, jaká pozice je držiteli moci při- \\
(Legitimate Power) & suzována \\
& (Legitimate position power) \\
& Legitimní moc daná reciprocitou \\
& (Legitimate power of reciprocity) \\
& Legitimní moc založená na vyrovnávání nerovnosti \\
& (Legitimate power of equity)
\end{tabular}




$\begin{array}{ll}\begin{array}{l}\text { Donucovací moc } \\ \text { (Coercive power) }\end{array} & \begin{array}{l}\text { Legitimní moc vyplývající ze sociální zodpovědnosti } \\ \text { Osobní donucovací moc } \\ \text { (Personal coercive power) } \\ \text { Neosobní donucovací moc } \\ \text { (Impersonal coercive power) }\end{array} \\ \begin{array}{l}\text { Odměňovací moc } \\ \text { (Reward power) }\end{array} & \begin{array}{l}\text { Osobní odměňovací moc } \\ \text { (Personal reward power) }\end{array} \\ \begin{array}{l}\text { Neosobní odměňovací moc } \\ \text { (Impersonal reward power) }\end{array} \\ \text { (Expert power) } & \begin{array}{l}\text { Pozitivní expertní moc } \\ \text { (Positive expert power) }\end{array} \\ \text { Negativní expertní moc } \\ \text { (Negative expert power) } \\ \text { Referenční moc } \\ \text { (Referent power) }\end{array}$

V rámci legitimní moci byly nově identifikovány čtyři typy moci: 1) legitimní moc vyplývajicí z toho, jaká pozice je držiteli moci prísuzována. Tato moc vychází ze sociálních norem, které určují, že v určitých sociálních pozicích se jedná o nadřazenost a s ní související vliv oproti jiným sociálním pozicím (např́ílad rodiče ovlivňují děti, učitelé studenty, policisté občany). 2) Legitimní moc danou reciprocitou lze popsat principem „něco za něco“. Vychází tedy ze závazku jednoho aktéra vưči druhému (např́ílad „pomohl jsem ti v nouzi, nyní máš závazek pomoci ty mně“). 3) Legitimní moc založená na vyrovnávání nerovnosti, kterou lze chápat jako kompenzační mechanismus (např́klad „tvoje chování mi ublížilo, a proto mám právo žádat, abys ho napravil“). 4) Legitimní moc vyplývající ze sociální zodpovědnosti - podle normy sociální zodpovědnosti máme povinnost pomáhat těm, kteři si nemohou pomoci sami nebo jsou na nás závislí, bývá proto označována jako moc bezmocných. Pokud např́iklad učitel přistupuje $\mathrm{k}$ žákovi tak, že je na něm závislý, může se žák cítit být povinen učiteli pomoci (např́ílad učitel řekne žákovi, že pokud žák nesplní úkol, nemůže učitel dál pokračovat).

Moc donucovací rozdělil Raven na osobní a neosobní. Typologie vychází z toho, že odmítnutí nebo nesouhlas ze strany toho, koho si vážíme, je zdrojem silné donucovací moci. $\mathrm{V}$ př́ípadě osobní donucovací moci se využívají osobní 
prostředky donucování (například odmítnutí), v prrípadě neosobní donucovací moci prostředky neosobní (např́klad fyzický trest).

Stejným způsobem Raven diferencoval také mocenskou bázi odměňovací. V rámci osobní odměňovací moci žák vnímá učitele jakožto někoho, kdo je schopen mu poskytnout odměnu, jež pro něj má subjektivní význam spojený s uznáním učitele (např́ílad pochvala), zatímco $v$ rámci percipované moci odměňovací neosobní je učitel potenciálním zprostředkovatelem odměny neosobní, často hmotné, kam je možné zařadit např́klad sladkosti.

V rámci moci expertní vymezil bázi pozitivní a negativní - pokud si žáci myslí, že učitel je „mistrem svého řemesla“, chovají se ve shodě s tím, jaké požadavky na ně učitel klade. Opačným pólem je situace, kdy se žáci domnívají, že učitel svému předmětu nerozumí, a proto učitelovy požadavky neplní.

Analogické je rozdělení také u moci referenční - pozitivní a negativní. Pokud učitel disponuje zejména percipovanou pozitivní referenční mocí, chová se žák tak, aby učiteli vyhověl, nebơ chce být jako on. Když naopak disponuje učitel zejména referenční mocí negativní, chová se žák v přímém rozporu s požadavky učitele, nebot rozhodně nechce být jako on.

Poslední mocenskou bázi, moc informační, pak Raven rozdělil na př́mou a neprímou informační moc. Podstata přímé informační moci spočívá v tom, že držitel moci informace sděluje a recipienta ovlivňuje prostřednictvím přímých sdělení (jasně dává najevo, co je jeho cílem), zatímco v prŕípadě moci nepřímé nikoli (využívá spíše náznaky, narážky, návrhy).

Jednotlivé báze prošly poslední úpravou ještě o dekádu později, kdy byly dále rozděleny na tvrdé a měkké (srov. např. Erchul, Raven, \& Ray, 2001; Erchul et al., 2001). Pokud je uplatňování určitého mocenského principu vnímáno jako tvrdé, znamená to, že je zjevné a nápadné, zatímco v př́padě percepce mocenské báze jakožto měkké může být téměř nepatrné. Vidíme, že tradiční diferenciace moci prošla celou řadou změn, nicméně autoři, kteří s bázemi Frenche a Ravena dále pracovali, se velmi často odvolávají právě na původní rozdělení podle pěti principů. O původní typologii se opírá také nástroj Schrodta, Witta a Turmana (2007), jejž jsme využili v našem výzkumu a jehož adaptaci se mimo jiné věnujeme v následující kapitole. 


\section{METODOLOGIE ZKOUMÁNÍ MOCI}

Kateřina Vlčková, Zuzana Šalamounová

Cílem této kapitoly je popsat postup, který jsme uplatnili v rámci výzkumného šetření zaměřeného na podobu mocenských vztahů ve třídách studentů učitelství. Na jaké otázky toto šetření odpovídá, o které metody sběru dat se opírá a s jakými cíli jsme k němu přistupovali, představujeme dále $\mathrm{v}$ této kapitole. ${ }^{14}$

\subsection{Cíl výzkumu a výzkumné otázky}

Cílem výzkumu bylo popsat, jaké podoby nabývá moc ve školních třídách na druhém stupni českých základních škol, v nichž vybraní studenti učitelství realizují svoji dlouhodobou učitelskou praxi. Zajímali jsme se o to, jakým způsobem se mocenské vztahy utvářejí, jakým způsobem se na jejich podobě vybraní studenti učitelství i jejich žáci podílejí a jak podobu moci ve třídě obě strany reflektují. Hlavní výzkumnou otázku jsme rozdělili do dílčích výzkumných otázek (srov. Merriam, 2002). Na následujících stranách tak odpovídáme na tyto výzkumné otázky:

1) Jak probíhá proces vyjednávání moci mezi vybranými studenty učitelství a jejich žáky ve vyučování na druhém stupni české základní školy v průběhu dlouhodobé pedagogické praxe?

2) Jak proces vyjednávání moci v průběhu dlouhodobé praxe reflektují vybraní studenti učitelství?

3) Jaká moc je vybraným studentům učitelství v průběhu školního pololetí přisuzována jejich žáky?

4) Jak je vyjednávána, uplatňována a reflektována legitimní, donucovací, odměňovací, expertní a referenční moc vybraných studentů učitelství ve vyučování?

\subsection{Smíšený design výzkumu}

Výzkum byl realizován ve smišeném designu, což jednoduše řečeno znamená, že vychází z postupů kvalitativního i kvantitativního výzkumu a jejich vzájemné interakce a dostává základnímu předpokladu smíšeného výzkumu, tj. že užití kvalitativního a kvantitativního přístupu současně umožňuje lepší pochopení výzkumného problému než pouze jeden z nich (srov. Creswell \& Plano Clark, 2007). Smíšený design je jednou z nejrychleji se rozvíjejících výzkumných metodologií (Bergman, 2008).

Dominantní status (Creswell, 1995) v našem výzkumu má kvalitativní šetření založené na designu blížícím se etnografickému přístupu. Etnografii, kterou u nás

14 Nad riziky zvolených výzkumných postupů se podrobněji zamýšlíme v diskusi této knihy (kap. 5). 
ve školním prostředí etablovala zejména Pražská skupina školní etnografie (viz např. PSŠE, 2001), lze v širším pojetí chápat jako tvorbu teorie kulturního chování uvnitř určité společnosti (Wolcott, 2008). Společenstvím svého druhu je také prostř̌edí školy a školní třídy, přičemž uspořádání mocenských vztahů, na něž se zaměřujeme, se stává významným aspektem kulturního chování.

Cílem doplňkového, vnořeného (nested; Miller \& Crabtree, 1994; Creswell \& Plano Clark, 2007) kvantitativního šetření bylo získat údaje od žáků o jejich reflexi bází moci studentů učitelství. Výsledky kvalitativní a kvantitativní části byly kombinovány s cílem jejich propojení (Creswell \& Plano Clark, 2007), jehož účelem bylo komplexnější a lepší porozumění fenoménu moci ve školních třídách. Výzkum je založen na triangulaci př́stupů, metod sběru dat a analýzy dat, typů dat a jejich interpretací. Do všech rovin výzkumu se promítla také triangulace výzkumníků, která měla za cíl eliminovat předpojatosti jednotlivých pozorovatelů či tazatelů (Flick, 2007). Výzkumníci se tak mohli také v průběhu výzkumu navzájem učit, což průběžně přispívalo k větší citlivosti v práci s daty.

\subsection{Výzkumný vzorek}

$\mathrm{V}$ předkládané monografii se zaměřujeme na výzkum výuky studentů učitelství, nebot právě studenti učitelství (a následně začínající učitelé) se v kontextu své pedagogické praxe nejvíce zabývají otázkami ustavování a uplatňování moci ve školních třídách a jsou jimi nejvíce znepokojeni (srov. Barquist Hogelucht \& Geist, 1997; Staton, 1992; z aplikačních, metodických prací viz i Cangelosi, 2006).

Náš vzorek studentů učitelství byl záměrně homogenní co do ročníku studia jednalo se o studenty prvního ročníku navazujícího magisterského studia učitelství, tedy o studenty, již realizují svoji první formální učitelskou praxi v rámci studia a kteří by se přibližně za dva roky mohli stát začínajícími učiteli. Tzv. dlouhodobou učitelskou praxi, jež je sledována, tak lze považovat za jejich první formální „testovací" období, ze kterého mohou následně čerpat zkušenosti v průběhu budoucí kariérní dráhy učitele, ale i v dalších praxích v prrípravném učitelském studiu. ${ }^{15}$

Výzkumný vzorek tvořilo osm studentů učitelství a žáci osmi třídních kolektivů (130 žáků vyplnilo dotazník ${ }^{16}$ o bázích moci studenta učitelství), v jejichž výuce tito studenti učitelství realizovali svou dlouhodobou jednosemestrální učitelskou praxi. Vzorek studentů učitelství byl záměrně heterogenní co do pohlaví a vzdělávací oblasti, již budou v budoucnu vyučovat (viz níže). Výzkum tedy probíhal u každého studenta učitelství v jedné třídě, nicméně student mohl během praxe vyučovat i v jiných třídách. Reflexe výuky ze tříd mimo výzkumný vzorek se objevovaly v rozhovorech i denících. $Z$ osmi studentů učitelství bylo sedm žen a jeden muž, a to v prvním ročníku navazujícího magisterského studia učitelství

15 Systém praxí na Pedagogické fakultě MU, v jehož rámci probíhal tento výzkum, je podrobně popsán v publikaci Švece, Pravdové a Svojanovského (2015).

16 Viz dále v kapitole o metodách sběru dat. 
občanské výchovy, dějepisu a českého jazyka a literatury, kteří realizovali svoji praxi v podzimním semestru 2013 (4 studenti, z toho u dvou byla data sbírána v lednu až únoru 2014) nebo jarním semestru 2014 (4 studenti, únor až červen). Studenti realizovali praxi na druhém stupni běžných českých základních škol (ISCED 2A), žáci ze vzorku byli tedy z šestého až osmého ročníku (tab. 2).

\section{Tabulka 2}

\section{Výzkumný vzorek}

\begin{tabular}{|c|c|c|c|c|c|c|}
\hline $\begin{array}{l}\text { Student } \\
\text { učitelství1 }\end{array}$ & Škola & Místo školy & $\begin{array}{l}\text { Vyučovaný } \\
\text { ročník }\end{array}$ & Předmět & $\begin{array}{l}\text { Maximální } \\
\text { počet žáků } \\
\text { př́tomných } \\
\text { př́i natáčení }^{18}\end{array}$ & $\begin{array}{l}Z \text { toho } \\
\text { dívek }\end{array}$ \\
\hline Radek & A & $\begin{array}{l}\text { vesnice v Olomouckém } \\
\text { kraji }\end{array}$ & 8 & $\begin{array}{l}\text { český } \\
\text { jazyk }\end{array}$ & 7 & 2 \\
\hline Věra & B & $\begin{array}{l}\text { město v Jihomoravském } \\
\text { kraji }\end{array}$ & 8 & $\begin{array}{l}\text { český } \\
\text { jazyk }\end{array}$ & 16 & 11 \\
\hline Lenka & $\mathrm{C}$ & $\begin{array}{l}\text { město v Jihomoravském } \\
\text { kraji }\end{array}$ & 8 & dějepis & 19 & 8 \\
\hline Alice & $\mathrm{D}$ & $\begin{array}{l}\text { město v Jihomoravském } \\
\text { kraji }\end{array}$ & 8 & $\begin{array}{l}\text { občanská } \\
\text { výchova }\end{array}$ & 16 & 11 \\
\hline Milena & $\mathrm{E}$ & $\begin{array}{l}\text { město v Jihomoravském } \\
\text { kraji }\end{array}$ & 8 & $\begin{array}{l}\text { občanská } \\
\text { výchova }\end{array}$ & 17 & 8 \\
\hline Karla & $\mathrm{F}$ & $\begin{array}{l}\text { město v Jihomoravském } \\
\text { kraji }\end{array}$ & 8 & dějepis & 15 & 7 \\
\hline Zdena & G & $\begin{array}{l}\text { město v Pardubickém } \\
\text { kraji }\end{array}$ & 6 & $\begin{array}{l}\text { český } \\
\text { jazyk }\end{array}$ & 23 & 14 \\
\hline Petra & B & $\begin{array}{l}\text { město v Jihomoravském } \\
\text { kraji }\end{array}$ & 7 & $\begin{array}{l}\text { český } \\
\text { jazyk }\end{array}$ & 21 & 13 \\
\hline
\end{tabular}

Při výběru participantů našeho výzkumu jsme se snažili zohlednit tato kritéria: absolvování dlouhodobé pedagogické praxe, deklarovaný zájem o výkon studované profese v budoucnu, hodnocení studentů jako talentovaných a angažovaných oborovými didaktiky, vlastní angažovanost studenta, jeho aprobace odpovídající plánu projektu. Vybírali jsme tedy záměrně participanty, dle daných kritérií reprezentující skupinu studentů, kteří plánují kariéru učitele opravdu započít.

17 Jména jsou anonymizována.

$18 \mathrm{~V}$ jednotlivých třídách byl v jednotlivých vyučovacích hodinách přítomen různý počet žáků. Uveden je maximální počet př́tomných $\mathrm{v}$ některé $\mathrm{z}$ natáčených hodin, $\mathrm{v}$ jednotlivých hodinách se nemusí jednat o tytéž žáky. 
Vzhledem k povaze výzkumu, jenž vyžadoval dlouhodobý úzký kontakt s participanty, byli vybíráni studenti, kteří svoji praxi vykonávali v rámci Jihomoravského kraje či v jeho blízkosti, tedy ve vzdálenosti umožňující realizovat výzkumné šetření v celé jeho šírii.

\subsection{Metody sběru dat}

Ve výzkumu bylo použito vícero metod sběru dat, jednalo se o tzv. multimethod design (Brewer \& Hunter, 1989, s. 17; Greene, 2007, s. 77). Stěžejní metodou sběru dat se stalo pozorování vyučovacích hodin vedených studenty učitelství, z nichž byly poř́zeny videozáznamy, které jsme později převedli také $v$ transkripty. Z pozorovaných hodin vznikaly také terénní zápisky jednotlivých výzkumníků. Jelikož analýza transkriptů videozáznamů a analýza videozáznamů představovaly jádro výzkumných analýz, je možné prezentovaný výzkum v tomto smyslu chápat jako tzv. videostudii. $\mathrm{Z}$ metodologického hlediska proto byla respektována pravidla realizace videostudie (srov. Seidel, Prenzel, \& Kobarg, 2005; Janík \& Miková, 2006). Dalšími metodami sběru dat (obr. 2) byly dotazníky pro žáky na reflexi moci studentů učitelství, reflektivní deníky studentů učitelství z praxí a rozhovory se studenty učitelství o výuce v daných třídách. Jednotlivé metody sběru dat podrobněji popisujeme dále.
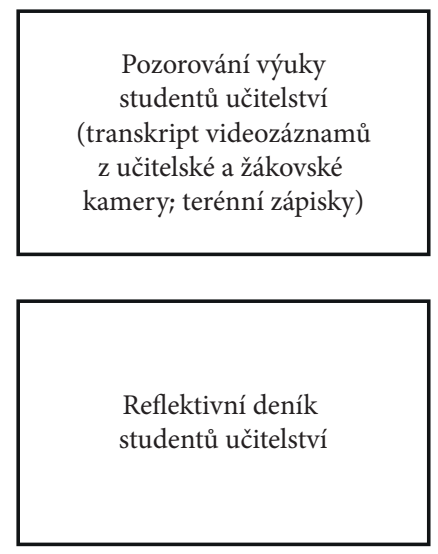

Obrázek 2. Metody sběru dat.

\subsubsection{Pozorování}

Ústřední metodu sběru dat v našem výzkumu představuje metoda pozorování. Každý z výzkumníků pozoroval výuku jednoho studenta učitelství, kterou 
současně zaznamenával na videokameru. Vzhledem $\mathrm{k}$ tomu, že při následující analýze se pracovalo zejména s videozáznamy výuky, tvoří klíčovou složku pozorování nepř́mé, resp. pozorování zprostředkované z videozáznamu. Analyzovány byly také transkripty videozáznamu, nicméně $\mathrm{k}$ analýze byl vždy nutný také videozáznam samotný. Jak jsme naznačili ve druhé kapitole této knihy, mocenské uspořádání je demonstrováno nejen verbálně, a proto se sledování videozáznamu stalo nezbytnou součástí další práce s datovým materiálem.

Sběr dat prostřednictvím pozorování probíhal v období od listopadu 2013 do května 2014. V této době byly ve výuce každého studenta pořízeny videozáznamy šesti po sobě jdoucích vyučovacích hodin (kromě studentky Alice, jež nabídla $\mathrm{k}$ natáčení jednu hodinu navíc). Videozáznam byl vždy snímán dvěma kamerami (obr. 3), z nichž jedna sledovala primárně chování učitele a druhá byla zaměřena na třídu jako celek a dle potřeby i na jednotlivé žáky, kteři aktuálně interagovali s učitelem. Kamera zaměřená na studenta učitelství byla statická a její umístění bylo vždy vzadu za žáky budto uprostřed, nebo v pravém zadním rohu (dle dispozice trí́dy). S pohyblivou kamerou snímající žáky výzkumník pracoval v přední části třídy, na opačné straně než katedra, obvykle tedy vlevo v rohu. Výzkumníci byli na těchto postupech dohodnuti před natáčením a s pohyblivou kamerou se mohli také zaměřovat na komunikaci učitele $s$ určitou skupinou žáků, pokud k nim učitel šel nebo se v ní dělo něco zajímavého z hlediska výzkumu moci ve třídě. Podoba výsledné nahrávky byla tedy mezi výzkumníky standardizována ve velmi základní podobě, a to výše uvedenými pravidly. Natáčení začínalo před zvoněním (především učitelská kamera byla zapnuta před začátkem vyučování) a končilo, když učitel výuku ukončil (ne nutně tedy zvoněním). Analýza přepisu se pak řídila dobou, kdy student učitelství či cvičný učitel výuku začal a skončil.

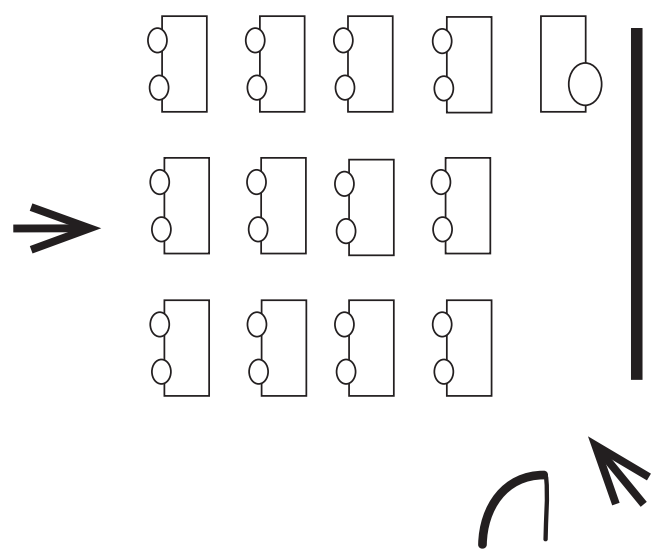

Obrázek 3. Postavení žákovské a učitelské kamery při videozáznamu výuky. 
Videozáznamy byly přepsány dle transkripčních pravidel (příloha 4; srov. Lefstein \& Snell, 2014), kdy cílem bylo vytvoření komplexního záznamu vyučovací hodiny, jehož pročtení umožní rekonstruovat co nejvěrohodnější obraz pozorovaného chování účastníků interakce. Do každého přepisu jsme se snažili zahrnout kompletní verbální komunikaci, neverbální komunikaci a veškeré důležité dění ve třídě. Zaznamenán byl také nejběžnější zasedací pořádek ve třídě (ukázka $\mathrm{v}$ príloze 4). Transkript se $\mathrm{v}$ naší knize objevuje $\mathrm{v}$ rámci ukázek $\mathrm{z}$ dat $\mathrm{z}$ pozorování. Výroky žáků a studentů učitelství jsou dle něho přepsány a prezentovány.

Před natáčením byl zajištěn písemný souhlas rodičù s natáčením. Žáci, jejichž rodiče vyjádřili nesouhlas s natáčením, seděli při natáčení vzadu ve třídě mimo záběr obou kamer, př́padně jim škola na natáčenou vyučovací hodinu zajistila náhradní program. Souhlas s natáčením a zpracováním dat podepisovalo také osm zúčastněných cvičných učitelů a zkoumaných osm studentů učitelství na praxi.

\subsubsection{Polostrukturovaný rozhovor}

Po natočení všech vyučovacích hodin byly se studenty učitelství realizovány rozhovory o tom, jak se ve třídě cítili, jak sami nahlíželi na uspořádání moci ve tř́idách, jak s žáky ustavovali nejrůznější pravidla apod. Jednalo se o rozhovory polostrukturované, tedy vycházející z předem připraveného tazatelského schématu (autorky K. Lojdová a Z. Šalamounová, př́loha 3), nicméně se mnohdy ubíraly daleko za předem dané otázky (př́loha 6). V ukázce 1 prezentujeme pouze hlavní otázky, dílčí tazatelské podotázky jsou k dispozici v př́loze 3.

\section{Ukázka 1}

\section{Schéma rozhovoru se studenty učitelství}

HVO: Jak proces vyjednávání moci v průběhu dlouhodobé praxe reflektují studenti učitelství?

SVO1: Jak studenti učitelství vnímají vstup do třídy, v níž realizují svoji praxi?

SVO2: Jak studenti učitelství vnímají své působení při ustavování mocenského uspořádání ve třídě, $\mathrm{v}$ níž realizují svoji praxi?

SVO3: Jak studenti učitelství vnímají postupy a strategie, jimiž do mocenského uspořádání vstupují jejich žáci?

SVO4: Jak studenti učitelství vnímají působení školy na mocenské uspořádání ve třídě?

Rozhovory byly vedeny výzkumníkem, který konkrétního studenta učitelství v průběhu výzkumu natáčel, a proto s ním již měl navázaný určitý vztah. Každý 
rozhovor byl zaznamenán ${ }^{19}$ na diktafon, a poté, stejně jako data z pozorování, převeden po podoby psaného textu dle transkripčních pravidel (příloha 4,5 a 6 ).

\subsubsection{Reflektivní deník}

Dalším zdrojem dat pro náš výzkum byly reflektivní deníky, které si studenti učitelství vedou $\mathrm{v}$ rámci výuky, tzv. reflektivních seminářů k pedagogickým praxím. Studenti odevzdávali své zápisky z deníků přibližně každých 14 dní do on-line Informačního systému Masarykovy univerzity, kde byly k dispozici vyučujícím jako podklad $\mathrm{k}$ vedení diskusí na seminárích. Jeden zápis měl průměrně rozsah dvou normostran, soubor reflexí pak cca deset normostran. Každý semestr měli studenti zadáno také určité zaměření deníků (např. cíle vyučovací hodiny, pojetí žáka, metody a formy výuky), přičemž našich osm zkoumaných studentů učitelství bylo požádáno, aby se zaměřovalo také na oblast autority, kázně, řízení třídy a moci. Elektronické deníky byly na konci výzkumu staženy z on-line systému a analyzovány. Zadání deníku a ukázka záznamu v deníku jsou k dispozici v příloze 7 a 8 .

\subsubsection{Dotazník „Báze moci: verze pro studenty učitelstvi““}

V osmi třídách vyučovaných zkoumanými osmi studenty učitelství na praxi jsme zadávali dotazník žákům, zjednodušeně pro ně nazvaný $O$ naši tř́́dě (př́loha 1 ). Jedná se o dotazník Báze moci: verze pro studenty učitelství (BMS; Vlčková, Mareš, \& Ježek, 2015), který je určen pro druhý stupeň základní školy a měří žákovskou reflexi bází moci studentů učitelství na praxích.

Tento dotazník jsme adaptovali ze škály Teacher Power Use Scale (TPUS) autorů Schrodta, Witta a Turmana (2007), která vychází z typologie relační moci Frenche a Ravena (1959) rozlišující pět bází moci: legitimní, donucovací, odměňovací, expertní a referenční. TPUS zjištuje pomocí 30 položek žáky reflektovanou moc vysokoškolského učitele na sedmibodové frekvenční odpovědové stupnici Likertova typu. Vykazuje podle srovnávacích konfirmačních faktorových analýz autorů (Schrodt, Witt, \& Turman, 2007) lepší psychometrické vlastnosti než dříve preferované nástroje - Peceived Power Measure (PPM) ${ }^{20}$ autorů McCroskeyho a Richmondové (1983) a později upřednostňovaný Roachův (1995) Power Base Measure (PBM). TPUS vykazuje lepší vnitřní konzistenci, souběžnou a diskriminační validitu a obsahuje validnější a reliabilnější indikátory pěti zmíněných bází učitelovy moci. Koeficient reliability Cronbachovo alfa ( $\alpha$ ) nabýval u subškál hodnot v rozmezí 0,77 až 0,90. Nástroj měří spolehlivěji také na agregované úrovni tzv. antisociální formy moci (tj. donucovací a legitimní) a prosociální

19 Rozhovory trvaly od 31 minut do 150 minut. Obvykle kolem 50 minut.

20 A na něj navázaný Relative Power Measure (RPM). 
formy moci (tj. referenční a odměňovací). ${ }^{21} \mathrm{Z}$ těchto důvodů byl TPUS zvolen jako výchozí nástroj pro náš výzkum a následně adaptován na podmínky našeho výzkumu (mladší žáci, český kontext, studenti učitelství). Cesta k vytvoření finální verze nástroje vedla přes prípravnou fázi, proto nejprve představíme tuto fázi a až poté se budeme věnovat finální verzi nástroje.

\section{Př́pravná fáze tvorby nástroje}

Adaptace nástroje probíhala ve dvou krocích. Škálu jsme nejprve adaptovali $z$ verze pro univerzitní učitele a jejich studenty na učitele druhého stupně základní školy a jejich žáky a $\mathrm{z}$ anglosaského kulturního a školního prostředí na české (Báze moci: verze pro učitele - BMU, Vlčková, Mareš, Ježek, \& Šalamounová, 2016 , v prípravě). Zahrnut byl několikanásobný překlad, zpětný překlad a opakovaná expertní posouzení. Položky byly přeformulovány do první osoby jednotného čísla tak, aby se žáci vyjadřovali o svých zkušenostech, nikoli obecně za třídu. Byly navrženy položky specifické pro české školní prostředí a odpovědová stupnice byla zkrácena na pětibodovou bez specifikace mezihodnot (souhlasím - nesouhlasím). Poté proběhla pilotáž (kognitivní rozhovor s respondenty ${ }^{22}$ a zadání nástroje ve dvou tř́dách), úpravy nástroje a následně sběr dat $s$ dotazníkem o 45 položkách (příloha 2) pro validizaci dotazníku. Tato část výzkumu proběhla na konci roku 2013. Dostupný vzorek tvořilo 117 tříd, resp. učitelů a 2188 žáků. Zahrnuty byly předměty dějepis, český jazyk, občanská výchova a zeměpis. Konfirmační faktorová analýza ${ }^{23}$ (CFA) v Mplus, verze 6 naznačila spíše existenci čtyř než pěti předpokládaných faktorů a shoda modelu byla po vyřazení několika položek akceptovatelná. Reliabilita subškál měřená pomocí Cronbachova alfa nabývala hodnot nad 0,7. (detailněji viz Vlčková, Mareš, Ježek, \& Šalamounová, 2016, $\mathrm{v}$ prípravě)

\section{Finální nástroj v našem výzkumu}

Výše uvedený adaptovaný dotazník Báze moci: verze pro učitele - BMU (Vlčková, Mareš, Ježek, \& Šalamounová, 2016, v př́ípravě) byl upraven pro podmínky výuky studentů učitelství, včetně doplnění specifických položek typických právě

21 S kategorizací antisociálních a prosociálních forem moci v našem výzkumu však nepracujeme, nebot jednotlivé báze chápeme jako a priori hodnotově neutrální s tím, že mohou nabývat antisociálních i prosociálních podob. Nicméně v našich výsledcích konfirmačních faktorových analýz a korelačních analýz tuto agregaci vidět lze (detailněji viz např. Vlčková, Mareš, \& Ježek, 2015). Pouze v kapitole 2.2 věnující se teorii moci učitele diskutujeme o antisociálních a prosociálních formách rezistence žáků.

$22 \mathrm{~V}$ našem výzkumu hovoříme o respondentech $\mathrm{v}$ tradici kvantitativního výzkumu. Jde tedy především o žáky, kteří vyplňovali dotazník na báze moci studenta učitelství. Jako informanty označujeme studenty učitelství, kteří nám poskytovali data prostřednictvím rozhovorů, deníků, pozorování - tedy v naší kvalitativní části výzkumu.

23 CFA byla realizovaná dr. Stanislavem Ježkem z Fakulty sociálních studií Masarykovy univerzity. 
pro studenty učitelství, například těch, které odkazují na cvičného učitele (příloha 1 a 2$)^{24}$

Sběr dat k validizaci dotazníku (př́loha 1 ) proběhl v roce 2014 na dostupném vzorku 96 tříd, resp. studentů učitelství a jejich 1686 žácích druhého stupně základní školy (93\%) či nižších ročnících víceletých gymnázií, a to v různých vyučovacích předmětech (jazyky, občanská výchova, prírodověda, fyzika, dějepis, atd.). Konfirmační faktorová analýza (CFA) ${ }^{25} \mathrm{v}$ Mplus, verze 7 ukazovala na jednodušší model než pětifaktorový (Vlčková, Mareš, \& Ježek, 2015). S oporou o výsledky CFA u učitelského dotazníku bylo zvoleno čtyřfaktorové řešení, jež slučuje bázi legitimní moci a donucovací moci. Shoda modelu byla po vyřazení tří položek akceptovatelná. Vyřazeny byly z dotazníku (př́loha 1) položky z legitimní/ donucovací báze moci: Tato učitelka ř́ká, že učitelé se musejí poslouchat (L05), Tato učitelka dává najevo, že ve škole se musí poslouchat (L11) a Když téhle učitelce nedonesu úkol, cítím se fakt špatně (D06). Reliabilita subškál (tj. jednotlivých bází moci) měřená pomocí Cronbachova alfa nabývala hodnot nad 0,80 (tab. 3).

Tabulka 3

Reliabilita škál a popisná statistika pilotní verze dotazníku BMS (pilotní výsledky PdF MU, 2014)

\begin{tabular}{llllll}
\hline Báze moci & $\begin{array}{l}\text { Cronbachovo } \\
\text { alfa }\end{array}$ & $\begin{array}{l}\text { Počet } \\
\text { položek }\end{array}$ & Průměr & Medián & SD \\
\hline Legitimní/donucovací & 0,83 & 20 & 2,40 & 2,35 & 0,63 \\
Odměňovací & 0,81 & 8 & 3,53 & 3,60 & 0,80 \\
Expertní & 0,88 & 9 & 4,13 & 4,33 & 0,75 \\
Referenční & 0,86 & 11 & 3,31 & 3,36 & 0,82 \\
\hline
\end{tabular}

Dotazník Báze moci: verze pro studenty učitelství (BMS; Vlčková, Mareš, \& Ježek, 2015 ${ }^{26}$ byl použit v našem smíšeném výzkumu moci ve výuce osmi studentů učitelství na praxích (př́loha 1). Zadával ho výzkumník, někdy student učitelství či cvičný učitel. Studenti učitelství obdrželi písemnou zpětnou vazbu k výsledkům dotazníku (zprávu) a ústní zpětnou vazbu k realizované výuce.

24 Př́klad položek: Tuhle učitelku poslouchám, protože mi to řekla naše paní učitelka (legitimní/donucovací moc L17). Když se téhle učitelce nelíbí, jak se chovám, stejně nemůže nic dělat, protože ještě není učitelka (legitimní/ donucovací moc L44). Když nepracuji tak, jak by si tahle učitelka přála, řekne to naší učitelce (legitimní/donucovací moc D34). Když mi to $v$ hodině téhle učitelky jde, řekne to naší učitelce (odměňovací moc O40).

25 CFA byla realizovaná dr. Stanislavem Ježkem z Fakulty sociálních studií Masarykovy univerzity.

26 U autorů je k dispozici zkrácená verze nástroje určená pro validizační šetření, které jsme realizovali v listopadu a prosinci 2015 . V současnosti data analyzujeme a námi navržené úpravy nástroje ověřujeme pomocí CFA a položkové analýzy. Připravujeme také manuál k oběma dotazníkům Báze moci: verze pro studenty učitelství a verze pro učitele druhého stupně základní školy (Mareš et al., 2016). 
V kapitolách knihy 4.1 až 4.6 s výsledky výzkumu týkajících se bází moci porovnáváme výsledky osmi studentů učitelství s pilotními výsledky studentů učitelství PdF MU z roku 2014; jedná se o výsledky z naší adaptace nástroje na širším vzorku (viz výše). Tato širší data zasazují báze moci detailněji zkoumaných osmi studentů učitelství do širšího kontextu studentů učitelství na Pedagogické fakultě Masarykovy univerzity a ukazují, kde se z hlediska žákovské percepce uplatňování bází moci našich osm zkoumaných studentů učitelství nachází.

\subsubsection{Fáze sběru dat}

Využití jednotlivých metod sběru dat v různých fázích výzkumu graficky zachycujeme na obrázku 4.

Říjen 2013 - leden 2014 (4 studenti učitelství)

Únor - červen 2014 (4 studenti učitelství)

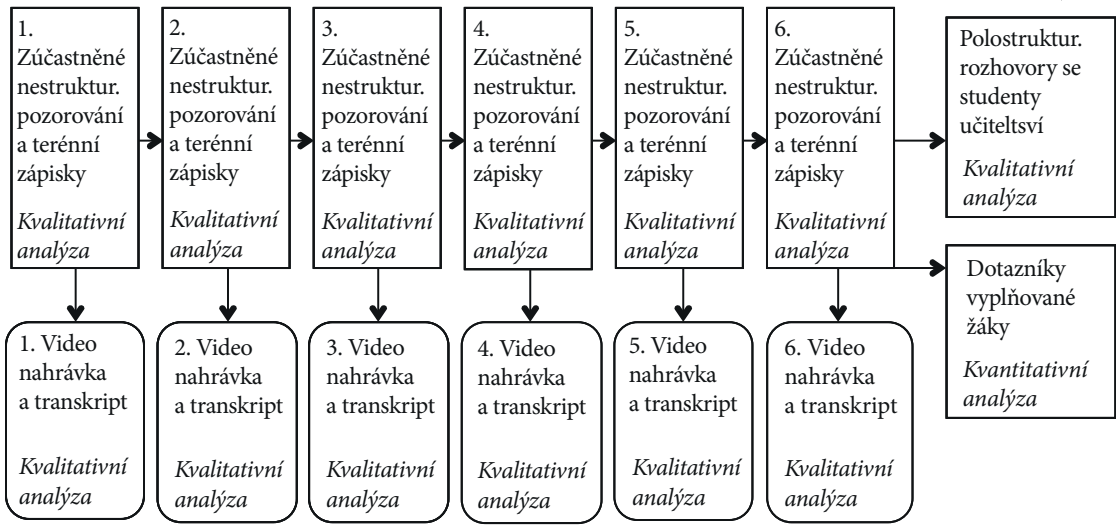

Reflektivní deník z praxe studentů učitelství

Kvalitativní analýza

Obrázek 4. Pořadí užití metod sběru dat s typem analýz dat.

\subsection{Analýza dat}

Analytické postupy byly uplatňovány v korespondenci s konkrétním výzkumným designem. Hlavní typ dat představovala kvalitativní data $\mathrm{z}$ pozorování (videozáznamy a jejich transkripty), z rozhovorů a deníků. Videozáznamy 49 hodin výuky byly přepsány do transkriptů podle transkripčních pravidel protokolu vyučovací hodiny (Janík \& Miková, 2006; Lefstein \& Snell, 2014; př́loha 4). 
Kvalitativní data byla analyzována pomocí kombinace tematického (Braun \& Clarke, 2006) a otevřeného kódování (Strauss \& Corbin, 1999; Švaříček \& Šed’ová, 2010). Skrze tematické kódování, které bylo deduktivní povahy, došlo zejména k organizování a sumarizování výzkumných dat (Braun \& Clarke, 2006). Tematického kódování jsme využili v tom smyslu, že byly sledovány kategorie bází moci (legitimní, donucovací, referenční, expertní a odměňovací). Před tematickým kódováním transkriptů i videozáznamů byl realizován zácvik všech šesti kódovatelů, jenž byl zaměřen na obecnou shodu na tom, co patří do jednotlivých bází moci. Báze moci byly kódovány jedním až dvěma výzkumníky: legitimní (Lojdová), donucovací (Lojdová, Lukas), expertní (Šalamounová), referenční (Kohoutek, Mareš) a odměňovací moc (Vlčková). Následná analýza dat (transkriptů videozáznamů, videozáznamů, rozhovorů, elektronických deníků) probíhala $\mathrm{z}$ větší části v programu ATLAS.ti verze 6 a 7. Po základní shodě výzkumníků na jednotce analýzy (výrok, situace, významový celek), podobě kódování (tematické, otevřené) a analýzy probíhalo kódování přepisů videozáznamů s ohledem na identifikovatelné projevy bází moci.

V této části výzkumu šlo také o spojování prrístupů smíšeného výzkumu na úrovni analýzy dat (Tashakkori \& Teddlie, 2003). Při kódování byly využity především charakteristiky bází moci z teorie a konkrétní položky bází moci z námi adaptovaného dotazníku Báze moci: verze pro studenty učitelství - BMS (Vlčková, Mareš, \& Ježek, 2015).

Prostřednictvím následujícího otevřeného kódování induktivní povahy jsme se poté pokoušeli nalézt $\mathrm{v}$ datech nové a neočekávané jevy, které lze pak uspořádat do určitých vztahů a následně interpretovat. Dalšími analytickými postupy byly konstantní komparace a analytická indukce. Tematické kódování umožnilo identifikovat např. sekvence donucovací moci a skrze otevřené kódování z nich vystoupily jejich dílčí charakteristiky a interpretace. Analýza a interpretace dat probíhala také v rámci smíšeného designu výzkumu, kvalitativní data jsou dokládána a orámována kvantitativními (dotazníkovými) a kvantitativní data jsou dokreslována kvalitativními. Data kvantitativní povahy pocházejí z dotazníku, jejž vyplňovali žáci a který měřil žákovskou percepci moci studentů učitelství ve školní třídě. Analýza těchto dat proběhla především v programu IBM Statistica CZ, verze 12 a zahrnovala základní deskriptivní statistiky (mediány, průměry, četnosti atd.). 


\section{VÝSLEDKY VÝZKUMU: IDENTIFIKOVANÉ PROJEVY BÁZÍ MOCI U STUDENTU゚ UČITELSTVÍ}

Ve druhé kapitole jsme popsali, že moc je ve školních třídách všudypř́tomná, nepřetržitě se pohybuje mezi učitelem a žáky i žáky navzájem a promítá se do ní mnoho nejrůznějších proměnných. Abychom proto byli schopni vysvětlit, co se z hlediska mocenského uspořádání odehrává ve školních třídách, v nichž vykonávají praxi studenti učitelství, rozhodli jsme se na moc nahlédnout vždy optikou jedné složky (či tzv. báze), která bývá moci tradičně přisuzována (viz kapitola 2). Jedná se o výše zmiňované báze moci, jež se v následujících podkapitolách pokusíme zasadit do kontextu jejich projevů ve výuce osmi studentů učitelství v průběhu jejich praxe.

Nejdřive (kapitola 4.1) představíme báze moci u všech osmi studentů ve výzkumném vzorku tak, jak je reflektovali jejich žáci prostřednictvím dotazníku Báze moci: verze pro studenty učitelství (Vlčková, Mareš, \& Ježek, 2015). Co konkrétně se v rámci jednotlivých bází ve výuce studentů učitelství na druhém stupni základní školy odehrává, odkrývá následných pět kapitol (4.2 až 4.6) věnovaných postupně všem bázím moci: legitimní, donucovací, odměňovací, expertní a referenční. $\mathrm{V}$ jednotlivých kapitolách jsou př̀ popisu výsledků uplatněny různé př́stupy $\mathrm{k}$ datům a výsledky kvalitativních a kvantitativních analýz se prezentují různým způsobem, $v$ různé proporci a pořadí. Tyto rozdílnosti jsou záměrné, jsou dány odlišnostmi jednotlivých bází moci. Do určité míry zde hraje roli také odlišné oborové zaměření autorů, opět však ve vazbě na konkrétní báze moci. $\mathrm{V}$ jednotlivých kapitolách je také různá proporce využití jednotlivých zdrojů dat (dotazníky, rozhovory, transkripty videozáznamů a videozáznamy, deníky, terénní zápisky), tato různorodost je také dána tím, ve kterých datových zdrojích byly $\mathrm{k}$ dispozici adekvátní informace $\mathrm{k}$ dané bázi moci. Například pro referenční moc se zdrojová data nacházela především ve výstupech $\mathrm{z}$ dotazníků a datech $\mathrm{z}$ rozhovorů, kdežto v pozorování velmi málo (na rozdíl např́ílad od donucovací moci). $\mathrm{Z}$ dat jsme tedy vždy vybírali to, co bylo relevantní pro danou bázi moci. Ukázky z dat jsou vybírány tak, aby ilustrovaly klíčové fenomény v dané bázi moci. 


\subsection{Báze moci studentů učitelství na praxi aneb Jak to vidí žáci}

Kateřina Vlčková, Kateřina Lojdová, Stanislav Ježek

Z našich výsledků výzkumu se nejprve podíváme na užívání námi zkoumaných pěti bází moci u osmi studentů učitelství ve výzkumném vzorku, a to prostřednictvím reflexe žáků. Vycházíme z výsledků dotazníku Báze moci: verze pro studenty učitelství (př́loha 1$)$, jejž vyplňovali žáci $(\mathrm{N}=130)$ druhého stupně základních škol ve třídách osmi studentů učitelství $\mathrm{z}$ výzkumného vzorku. $\mathrm{K}$ dispozici máme také výsledky od dalších 96 studentů učitelství a jejich 1686 žáků, které v naší knize zasazují výsledky osmi zkoumaných studentů učitelství do širšího kontextu. Ve výsledcích týkajících se uplatňování bází moci je prezentujeme jako srovnávací, pilotní výsledky studentů učitelství z Pedagogické fakulty Masarykovy univerzity (PdF MU) z roku 2014 (více viz kapitola 3.4.4).

\section{Sloučení legitimní a donucovací báze moci v kvantitativních analýzách}

Jedním z prvních výsledků v kvantitativní části našeho výzkumu bází moci je sloučení dvou z nich - legitimní a donucovací báze moci. Ke sloučení došlo na základě adaptace dotazníku Teacher Power Use Scale - TPUS (Schrodt, Witt, \& Turman, 2007), při které se skrze konfirmační faktorovou analýzu ukázalo, že legitimní a donucovací báze moci tvoří v českých datech žáků druhého stupně jeden faktor (více viz Vlčková, Mareš, \& Ježek, 2015; Vlčková, Mareš, Ježek, \& Šalamounová, 2016, v př́ípravě). Tyto báze spolu také silně korelovaly (Cronbachovo alfa nabývalo hodnoty 0,85 ). Není to přitom zjištění úplně překvapivé, jelikož i autoři TPUS Schrodt, Witt a Turman (2007) reportovali, že nástroj dobře měří na agregované úrovni donucovací a legitimní bázi moci. V jejich datech však sloučení daných bází nebylo vhodným řešením. Také například Elias a Mace (2005), kteří zkoumali báze moci na vzorku 325 univerzitních studentů, zjistili, že některé z bází spolu pozitivně korelují. Autoři však využili modifikovanou verzi dotazníku Ravena, Schwarzwalda a Koslowského (1998) Interpersonal Power Inventory (IPI), v němž byly báze moci pojaty odlišně od našeho výzkumného nástroje. Navíc se jejich šetření netýkalo žáků druhého stupně základní školy (podobně jako u Schrodta, Witta a Turmana, 2007), na které se zaměřujeme my.

Přestože $\mathrm{v}$ kvantitativních datech legitimní a donucovací moc slučujeme (v souladu s vnímáním těchto mocenských bází žáky), v datech kvalitativních lze tyto báze identifikovat odděleně (pohled výzkumníků). V interpretacích lze tedy hovořit o moci legitimní a donucovací separovaně, proto těmto bázím moci věnujeme dvě samostatné kapitoly (4.2 a 4.3$)$. 


\section{Uplatňování bází moci studenty učitelství v našem vzorku ve srovnání s šir- ším vzorkem}

Na žáky reflektované uplatňování jednotlivých bází moci osmi zkoumaných studentů učitelství jsme nahlíželi pomocí základních deskriptivních statistik. Orientačně nabízíme také porovnání s pilotními výsledky 96 studentů učitelství PdF MU z roku 2014. Tabulka 4 ukazuje průměry žáky $(\mathrm{N}=130)$ reflektovaného použivání bází moci osmi studentů učitelství v našem výzkumném vzorku a 96 studentů učitelství PdF MU na praxích. V grafu následuje přehledné porovnání bází moci a obou vzorků (obrázek 5).

Tabulka 4

Pohled žáků na uplatňování bází moci studentů učitelství

\begin{tabular}{lcccccc}
\hline \multirow{2}{*}{ Báze moci } & \multicolumn{3}{c}{$\begin{array}{c}\text { 8 studentů učitelství } \\
\text { v našem vzorku }\end{array}$} & \multicolumn{3}{c}{$\begin{array}{c}96 \text { studentů učitelství } \\
\text { PdF MU (2014) }\end{array}$} \\
& Medián & Průměr & SD & Medián & Průměr & SD \\
\hline Legitimní/donucovací & 2,39 & 2,39 & 0,72 & 2,35 & 2,40 & 0,63 \\
Odměňovací & 3,75 & 3,75 & 0,79 & 3,60 & 3,53 & 0,80 \\
Expertní & 4,33 & 4,17 & 0,78 & 4,33 & 4,13 & 0,75 \\
Referenční & 3,27 & 3,26 & 0,83 & 3,36 & 3,31 & 0,82 \\
\hline
\end{tabular}

Poznámka. Odpovědová stupnice je od 1 do 5 (souhlasím).

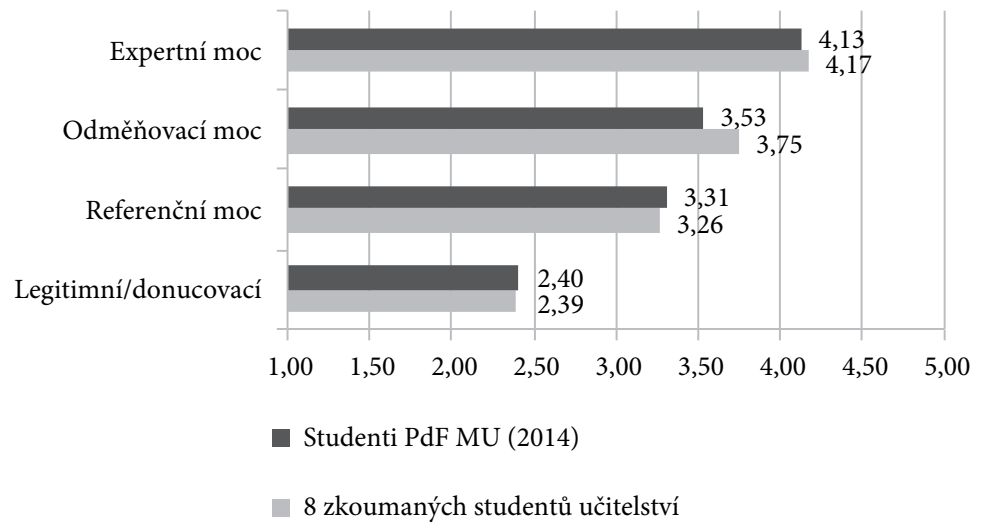

Poznámka. Osa x představuje průměrnou míru žáky reflektovaného uplatňování bázi moci na odpovědové stupnici od 1 po 5 (souhlasím).

Obrázek 5. Porovnání průměrů uplatňování bázi moci u našeho vzorku a širšího vzorku studentů PdF MU z roku 2014. 
Výsledky ukazují (tab. 4), že náš vzorek osmi studentů učitelství se z pohledu žáků nijak výrazně neodlišuje od širšího vzorku studentů učitelství PdF MU na praxích. Porovnání je ovšem jen orientační (vzhledem k velikosti vzorku a typu výběru bez statistického testování), a to na základě průměrů a směrodatných odchylek obou výzkumných vzorků (tab. 4). Nepatrně více je osmi studenty učitelství v našem vzorku oproti srovnávacímu vzorku studentů učitelství PdF MU (2014) používána odměňovací moc (o 0,22 bodu více, na odpovědové stupnici od 1 po 5). Ostatní rozdíly jsou (na odpovědové stupnici od 1 do 5) velmi malé, tedy zanedbatelné (rozdíl u expertní moci je 0,04 bodu, referenční 0,05 a legitimní/donucovací 0,01 bodu). Drobný rozdíl v uplatňování odměňovací moci se zdá být zapřičiněn tím, že osm studentů učitelství v našem vzorku mělo pravděpodobně více kontaktu s cvičnými učitelkami než studenti ze srovnávacího vzorku PdF MU, a častěji tak mohli chválit žáky před cvičnou učitelkou za jejich chování nebo učební výsledky. To naznačují největší rozdíly ve výsledcích mezi vzorkem osmi studentů a srovnávacím vzorkem PdF MU u dvou položek dotazníku: Když jsme ve výuce téhle učitelky ${ }^{27}$ hodní, pochválí nás naší učitelce (O51) a Když mi to $v$ hodině téhle učitelky jde, řekne to naší učitelce (O40). Celkově však i ostatní položky odměňovací báze moci (viz dotazník, příloha 1) byly žáky reflektovány jako více uplatňované ve vzorku osmi studentů než ve vzorku PdF MU, což může být dáno tím, že se jednalo o motivované studenty, kteři plánují jít po dokončení školy učit, mají tedy spíše pozitivní vztah k žákům než ti, kteří pro učitelskou profesi ještě nejsou zcela rozhodnuti. Je také možné, že se v případě odměňovací moci projevil vliv natáčení (jenž však není v dotazníkových datech u ostatních bází za celek osmi studentů viditelný). Ten by způsobil např́klad, že studenti učitelství v našem vzorku žáky více chválí, protože je jejich výuka natáčena, a oni tak žáky motivují či se žáci opravdu chovají o něco lépe.

Shodně studenti učitelství v našem vzorku a srovnávacím vzorku 96 studentů učitelství PdF MU (2014) uplatňují jednotlivé báze moci co do jejich pořadí: nejvíce žáci reflektují používání expertní moci, poté odměňovací a referenční, nejméně legitimní/donucovací (obr. 5). Tyto rozdíly jsme orientačně (vzhledem $\mathrm{k}$ nenáhodnému výběru vzorku) testovali na zmíněném srovnávacím vzorku 96 studentů učitelství PdF MU z roku 2014, a to pomocí neparametrické Friedmanovy ANOVY. Rozdíly byly statisticky významné (ANOVA Chí ${ }^{2}(\mathrm{~N}=1684$, $\mathrm{sv}=3)=2644,20, \mathrm{p}=0,00)$. Orientačně použité post hoc testy naznačují statisticky významné rozdíly mezi všemi jednotlivými bázemi moci (při $\mathrm{p}=0,00$ ). To znamená, že žáci reflektují jako nejvíce používanou expertní moc studentů učitelství, dále odměňovací (rozdíl 0,60 bodu na odpovědové stupnici od 1 do 5 oproti posledně jmenované bázi), poté referenční (rozdíl 0,22 bodu) a nejméně legitimní/donucovací bázi moci (rozdíl 0,90 bodu). Na vzorku našich osmi studentů učitelství jsou rozdíly podobné: žáci reflektují jako nejvíce používanou 
expertní moc, dále odměňovací (rozdíl 0,42 bodu), poté referenční (rozdíl 0,49 bodu) a nejméně legitimní/donucovací bázi moci (rozdíl 0,89 bodu).

Co se týče výsledků námi detailněji zkoumaných osmi studentů učitelství (tab. 4), ukazuje se, že v dotaznících žáci připsali těmto studentům učitelství jako nejvíce ze všech bází moci uplatňovanou moc expertní $(\bar{x}=4,17, S D=0,78)$. Studenti učitelství, stojící na samém počátku své profesní dráhy, jsou překvapivě žáky považováni za experty. Proč tomu tak je a kdy je student učitelství v očích žáka expertem, vysvětluje kapitola 4.5.

Jako druhou nejvýraznější bázi moci u studentů učitelství na praxi vidí žáci moc odměňovací. Znamená to, že studenta učitelství chápou žáci jako někoho, kdo obvykle $(\bar{x}=3,75)$ disponuje odměnami, které jsou pro ně relevantní. O jaké odměny se jedná a jakým způsobem studenti učitelství disponují známkováním jako tradiční podobou odměňování (ale i trestání) ve škole, popisuje kapitola 4.4.

Referenční moc byla žáky vnímána jako druhá nejméně uplatňovaná báze moci zkoumanými studenty učitelství na praxích $\mathrm{v}$ jejich třídách $(\overline{\mathrm{x}}=3,27, \mathrm{SD}=0,83)$. Na první pohled se může zdát, že je to právě efekt nového učitele a mládí praktikantů, které budou naplňovat jejich moc ve třídě. V poslední empirické kapitole 4.6 však ukazujeme, že pro moc založenou na vztahu a identifikaci žáka s učitelem nejsou tyto charakteristiky výhradní. K navázání a prohloubení vztahu je jistě třeba více času než nabízí jednosemestrální praxe a šest odučených hodin v jedné třídě. Proto je zřejmé, že nižší reflektované uplatňování referenční moci oproti moci expertní či odměňovací není dáno jen vlastnostmi a dovednostmi studentů, ale velmi výrazně také systémem, v němž studenti učitelství praxi vykonávají.

Nejméně používanou bází moci u osmi studentů učitelství je legitimní/donucovací báze moci $(\bar{x}=2,39, S D=0,72)$. Bylo tomu tak u sedmi studentů učitelství z osmi, pouze u studentky učitelství Alice nabyla nejnižší hodnotu moc referenční (viz kap. 4.3). Protože u Alice je legitimní/donucovací báze moci v žákovské perspektivě nejvýraznější ( $\bar{x}=2,99, \mathrm{SD}=0,38)$, i když rozdíl není nijak veliký oproti ostatním studentům, věnujeme se v kapitole $4.3 \mathrm{~s}$ výsledky o donucovací moci často interpretaci kvalitativních dat z její výuky. Kvalitativní data v kapitole 4.3 dokreslují, jakých konkrétních charakteristik nabývá výuka studentky s patrnější donucovací mocí, i když je třeba současně také brát v potaz, že průměrná míra $(\bar{x}=2,99)$ uplatňování legitimní/donucovací moci u Alice je ve skutečnosti kolem středu na sledované odpovědové stupnici od 1 do 5 , nejedná se tedy o výrazné uplatňování dané báze moci.

\section{Srovnání uplatňování bází moci u osmi zkoumaných studentů učitelství na praxi}

Po souhrnné charakteristice uplatňování bází moci u námi zkoumaných studentů učitelství se zaměříme ještě na srovnání uplatňování jednotlivých bází moci mezi nimi. Průměrné hodnoty používání bází moci u jednotlivých studentů učitelství jsou k dispozici v tabulce 5 a přehledně srovnání znázorňuje obrázek 6 . 
4 VÝSLEDKY VÝZKUMU

Tabulka 5

Porovnání bází moci u osmi zkoumaných studentů učitelství

\begin{tabular}{lcccccccccc}
\hline Báze moci & \multicolumn{8}{c}{ Průměr žáky reflektovaného použivání báze moci studentem učitelství } \\
& Petra & Alice & Radek & Milena & Karla & Lenka & Věra & Zdena & $\begin{array}{c}\text { Studenti } \\
\text { PdF MU } \\
(2014)\end{array}$ \\
\hline $\begin{array}{l}\text { Legitimní/ } \\
\text { donucovací }\end{array}$ & 2,34 & 2,99 & 2,16 & 2,84 & 2,49 & 2,10 & 1,81 & 2,42 & 2,40 \\
$\begin{array}{l}\text { Odměňovací } \\
\text { Expertní }\end{array}$ & 3,40 & 3,40 & 3,48 & 4,35 & 3,73 & 3,99 & 3,85 & 3,60 & 3,53 \\
Referenční & 3,68 & 2,94 & 4,33 & 4,89 & 4,13 & 4,41 & 4,38 & 4,33 & 4,13 \\
\hline & 3,15 & 2,25 & 3,32 & 4,27 & 2,87 & 3,45 & 3,38 & 3,14 & 3,31 \\
\hline
\end{tabular}

Poznámka. Odpovědová stupnice je od 1 po 5 (souhlasím).

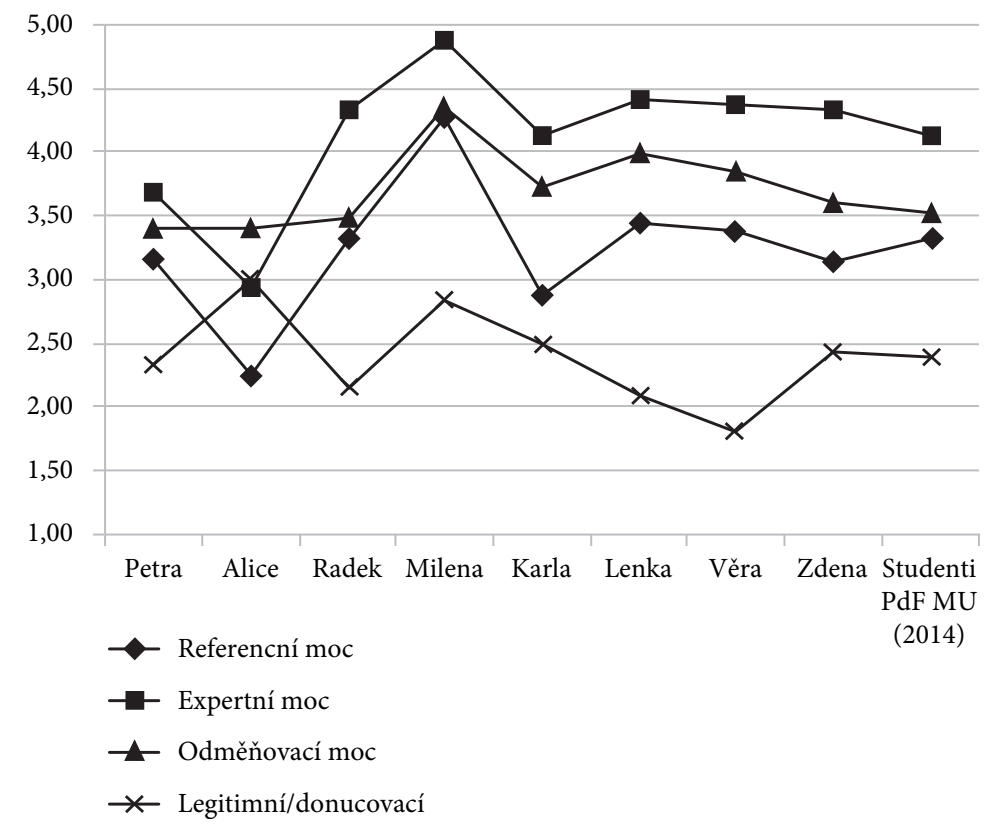

Poznámka. Spojnice v grafu neoznačují trend, nejedná se o spojitá data, pouze usnadňují čtenáři orientaci ve výsledcích za danou bázi moci. Osa y vyjadřuje průměrnou míru uplatňování bází moci studenty učitelství na odpovědová stupnici od 1 po 5 (souhlasím).

Obrázek 6. Porovnání uplatňování bází moci u zkoumaných osmi studentů učitelství. 
Z obrázku 6 je patrné, že uplatňování bází moci jednotlivými studenty učitelství, tak jak ho reflektují žáci, má prakticky stejné pořadí, které koresponduje s výsledky studentů učitelství PdF MU z roku 2014. Výjimku mezi našimi osmi detailněji zkoumanými studenty učitelství představuje žákovská reflexe bází moci u studentky učitelství Alice, jež podle žáků používá nejvíce odměňovací moc $(\bar{x}=3,40)$, poté legitimní/donucovací $(\bar{x}=2,99)$ a expertní $(\bar{x}=2,94)$ a nejméně referenční moc $(\bar{x}=2,25)$. Rozdíly mezi studenty ani mezi využíváním bází moci nejsou testovány statisticky, pouze je naznačujeme na základě průměru percipovaného uplatňování daných bází moci studenta učitelství žáky.

\section{Shrnutí: Reprezentativnost výsledků našeho výzkumu osmi studentů učitelství}

Důležitou otázkou pro teorii, praxi i navazující výzkum je, zda výsledky bází moci prezentované v našich empirických kapitolách 4.1 až 4.6 vypovídají pouze o osmi studentech učitelství, kteří byli participanty našeho výzkumu, anebo reflektují tento fenomén i u dalších studentů učitelství.

$\mathrm{Z}$ tohoto důvodu jsme realizovali srovnání výsledků osmi studentů učitelství ve vzorku s pilotními výsledky za PdF MU z roku 2014 (více viz kap. 3), které mohou ilustrovat, nakolik jsou výsledky vypovídající pouze o osmi studentech a jak moc vypovídají o širší skupině dalších studentů učitelství. V rámci smíšeného designu výzkumu se nám podařilo získat kontextová data o percepci bází moci studentů učitelství žáky i dalších studentů Pedagogické fakulty MU. Tyto srovnávací výsledky se zakládají na výsledcích dotazníku Bází moci na vzorku 96 studentů učitelství a jejich 1686 žáků. Výsledky ukazují (viz výše), že náš vzorek osmi studentů učitelství se z pohledu žáků nijak výrazně neodlišuje od širšího vzorku studentů učitelství PdF MU na praxích. Porovnání je ovšem jen orientační (bez statistického testování), a to na základě průměrů a směrodatných odchylek obou výzkumných vzorků.

Porovnání osmi zkoumaných studentů učitelství s těmito pilotními výsledky PdF MU (2014) naznačuje (viz výsledky prezentované výše), že našich osm bliže zkoumaných studentů učitelství reprezentuje širší skupinu studentů Pedagogické fakulty MU. V tomto smyslu lze tedy i výsledky dále prezentovaných kvalitativních analýz (kap. 4.2 až 4.6) považovat za reprezentující výuku studentů učitelství PdF MU v navazujícím magisterském studiu na počátku jejich prvních formálních zkušeností s výukou žáků na druhém stupni základní školy. V závislosti na tom, jak podobná je př́prava studentů učitelství na pedagogických fakultách v ČR a vedení cvičnými učiteli na praxích, a při zohlednění dalších intervenujících proměnných, pak můžeme usuzovat na možnou podobnost našich výsledků $s$ výsledky jiných skupin studentů učitelství. Pozitivním zjištěním v tomto ohledu také je, jak naznačují výše prezentované výsledky, že realizace výzkumu (zejména natáčení výuky) neovlivnily výsledky dotazníkového šetření mezi žáky nijak výrazně. 


\subsection{Legitimní báze moci aneb Vypůjčená moc studenta učitelství}

Kateřina Lojdová

Legitimní moc učitele je spojena s oprávněním mocensky působit ve třídě a vyplývá ze sociální role, jíž učitel nabývá v instituci školy. Od učitele se očekává, že bude vzdělávat a vychovávat žáky. Přestože výchovně-vzdělávací proces chápeme jako vzájemné působení učitele a žáků, je to právě učitel, který z podstaty své role vystupuje v těchto procesech v nadřazené mocenské pozici, což znamená, že dominantně právě on zadává instrukce a uděluje př́kazy, kterým se žáci více či méně podřizují. Jak jsme uvedli v kapitole 2.6.1 o legitimní moci, v prŕípadě učitelů je jejím zdrojem samotná role učitele a postavení učitele ve společnosti, pozice v organizaci školy, zřizovatelé školy, rodiče a žáci. Pro studenty učitelství tyto zdroje legitimity nejsou stejně významné jako pro učitele. $Z$ výše uvedených aktérů jsou pro ně těmi, kteří jim mohou připsat legitimní moc, zejména cviční učitelé a žáci.

Přestože se v této kapitole soustředíme na moc legitimní, budeme se místy přibližovat také úvahám o moci donucovací. Žáci (s různou mírou konformity) podléhají nastavení situace učitelem ve třídě, v důsledku jeho uplatňování legitimní a donucovací moci souběžně. Promítají se do toho i další mocenské báze, avšak zejména legitimní a donucovací moc lze obtížně oddělit.

Jedním z výsledků našeho výzkumu je tedy skutečnost, že legitimní moc je často výrazně doprovázena mocí donucovací a naopak (viz kapitola 4.1). Pokud by totiž učitel „neměl“ legitimní moc, jeho uplatňování donucovací moci by bylo mnohem obtižnější. Př́kladem může být zadávání úkolů žákům, nebot žáci budou na úkoly přistupovat jen tehdy, pokud jim je zadá někdo, kdo je k zadávání úkolů oprávněn. Bez legitimní moci nelze udílet žákům př́kazy, kterým by se podřizovali (představme si, že do školní třídy přijde neznámá osoba a bude po žácích chtít, aby jí odpovídali na otázky). Tyto báze mají k sobě blízko i tím, že se vzájemně předurčují. Jedná se přitom o kruh, kde jsou obě báze v různé míře primární i sekundární. Převažující primární legitimní moc může vést sekundárně $\mathrm{k}$ moci donucovací např́ílad v př́padě, kdy studenti učitelství získali legitimní moc při vstupu do třídy od cvičného učitele a na základě tohoto připsání moci začali přirozeně uplatňovat prostředky moci donucovací. Naopak primární výkon donucování (s nízkou mírou legitimní moci) může vést sekundárně k legitimizaci a legitimní moci aktéra, který donucuje. Jinými slovy žáci si zvykají na to, že nad nimi student učitelství uplatňuje donucovací prostředky a zpětně je pak považují za legitimní.

Agregovaná legitimní/donucovací báze moci byla žáky ve třídách zkoumaných studentů učitelství vnímána jako báze nejméně uplatňovaná ze všech čtyř mocenských bází (vyšší hodnotu tedy měly báze referenční, odměňovací 
a expertní) stejně jako u dalších studentů učitelství, kteří tvoří referenční vzorek pro srovnání s výsledky studentů z našeho výzkumu (tabulka 4, obrázek 5, s. 61).

Tabulka 4 (s. 61) ukazuje porovnání percepce bází moci u studentů učitelství žáky. Průměr legitimní/donucovací moci je u osmi námi zkoumaných studentů učitelství 2,39 (na škále od 1 - nesouhlasím po 5 - souhlasím). Stejně tomu bylo i u ostatních studentů učitelství (mimo výzkumný vzorek osmi studentů), kde tato báze disponovala nejnižší hodnotou $(\bar{x}=2,40)$. Legitimní/donucovací moc (v níž získali studenti od žáků nejnižší hodnoty) tvoří nejslaběji percipované báze moci studentů učitelství. Jedinou výjimkou byla studentka Alice, u které žáci percipovali na škále od 1 do 5 (kde 5 je nejvyšší hodnota) jako nejméně uplatňovanou bázi referenční $(\bar{x}=2,25)$, přičemž legitimní/donucovací moc u této studentky byla druhá nejméně používaná, ve vzorku osmi studentů však nabývala nejvyšších hodnot $(\bar{x}=2,99)$. Připsanou míru legitimní/donucovací moci u jednotlivých osmi studentů v našem vzorku ukazuje obrázek 7.

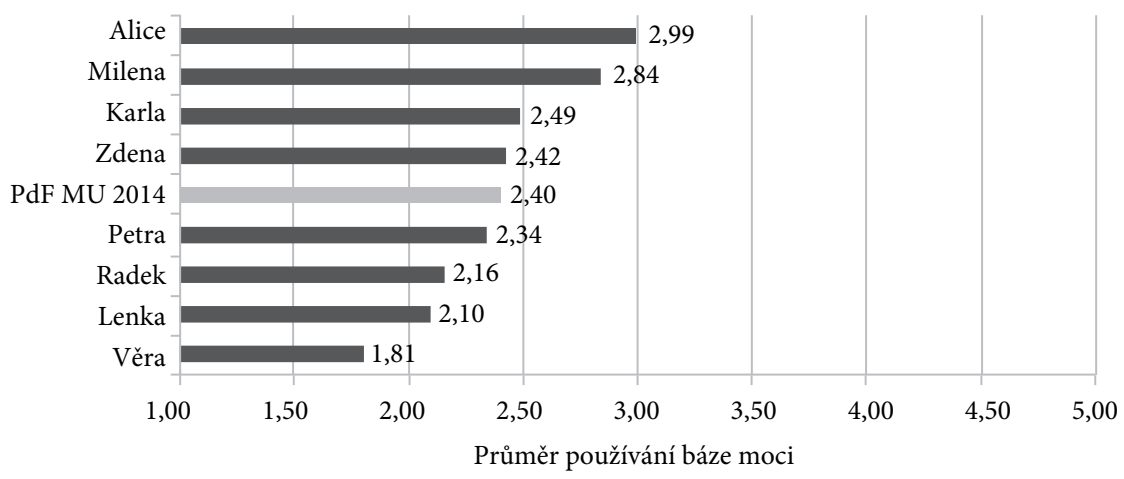

Poznámka. Odpovědová stupnice je od 1 po 5 (souhlasím).

Obrázek 7. Legitimní/donucovací moc u studentů učitelství ve vzorku.

V této chvíli se zaměříme na aspekty legitimní moci. Zamysleme se nejprve nad tím, co představuje nízká míra připsané legitimní moci u studentů učitelství na praxi. Jistě neznamená, že tato moc ve školní třídě z velké míry absentuje. Legitimní moc je totiž poměrně obtížně uchopitelná. Vystihla to ve svém deníku studentka učitelství Věra, která ji chápe jako „moc mezi řádky“. V našem výzkumu je legitimní moc specifická tím, že jejími nositeli jsou studenti učitelství na praxi ve škole, nikoliv učitelé.

Studenti na praxi nemají pevné místo v hierarchii školy a role učitele je jim jen „propůjčena“. Jejich legitimní moc omezuje řada faktorů. Z povahy praxe vyplývá, že jsou studenti ve škole jen na dobu určitou. $S$ tím také souvisí nedostatek času pro 
vytvoření vztahu se žáky a ustavení rutin spolupráce. Podobné fenomény popisují také Clark, Livingstone a Smaller (2012) u př́ležitostných učitelů a dodávají, že tato specifická pozice ve škole ovlivňuje mocenské uspořádání $v$ jejich třídách. Tito učitelé se potýkají s většími problémy než ostatní učitelé. Žáci různým způsobem testují jejich legitimní moc, např́klad tím, že přetočí nástěnné hodiny ve třídě, vymění si cedulky se jmény či místa ve třídě. Oproti př́ležitostným učitelům mají studenti na praxi ještě jedno specifikum - nemají dokončené formální vzdělání. Sami se proto mnohdy za učitele ještě nepovažují. Takto sám sebe vnímal např́klad Radek:

\section{Ukázka 2}

Tazatel: Mám pocit, že o sobě stále ještě nepřemýšlíte jako o učiteli. Že se stále vnímáte jako student.

Radek: Mhm.

Tazatel: Ne jako učitel?

Radek: No určitě.

Tazatel: Co Vás k tomu vede? I přesto, že už máte hodně odučené, že na škole celkem suverénně působíte?

Radek: Protože, protože, protože nejsem učitel.

Tazatel: Mhm.

Radek: Takže nemám potřebu ze sebe dělat učitele, když nejsem učitel.

Tazatel: Mhm. A co Vás udělá učitelem?

Radek: No až dostuduji školu.

Studenti na praxi jmenovali deficit $\mathrm{v}$ aspektech naplňující legitimní moc jako je pevné místo ve struktuře instituce školy, dokončené formální vzdělání či dlouhodobá spolupráce se žáky. Jak specifické postavení studentů vnímali žáci zjištovala v dotazníku položka Když se tomuto učiteli nelíbí, jak se chovám, stejně nemůže nic dělat, protože ještě není učitel. U studenta Radka, který výše hovoří o deficitu formálního vzdělání, byla hodnota položky třetí $z$ nejnižších $(\bar{x}=1,86)$, zřejmě proto, že před žáky vystupoval suverénně a nepotýkal se s kázeňskými problémy. Naopak nejvyšší byla hodnota této položky u studentky Alice $(\bar{x}=3,75)$, pro niž bylo obtížné řídit tř́́du, a musela tak žáky často ukázňovat. Žáci tedy vztahují legitimní moc k aktuálnímu výkonu studenta ve tř́ídě spíše než k jeho formálnímu vzdělání.

Přestože je legitimní moc obtížně uchopitelná, pozorování dění ve tř́́dě nám umožňuje popsat situace, ve kterých legitimní moc studentů učitelství jasně vystupuje do popředí. Jsou jimi především interakce studenta učitelství s cvičným učitelem před tř́dou, nebot cvičný učitel je tím, kdo studentovi legitimní moc pro působení ve třídě propůjčuje, a tím i připisuje. Cvičný učitel ovlivňuje vstup studenta učitelství do nového prostředí školy a ustavení role studenta ve školní třídě. Cvičný učitel tak střeží pomyslnou bránu do každé třídy, a velmi tedy záleží na tom, jak studenta touto branou provede. Získávání legitimní moci je procesem, 
jenž začíná představením studenta žákům ve třídě, pokračuje přítomností či nepř́tomností cvičného učitele ve školní třídě v průběhu praxe a podobou interakce cvičného učitele se studentem před zraky žáků. To, jakým způsobem tyto procesy probíhají, determinuje možnosti uplatnění legitimní moci studenta učitelství ve tř́dě, ve které praktikuje. Cvičného učitele jsme v kapitole 1.2.1 označili jako kritického druhého, tedy jako někoho, kdo má na studenta učitelství výrazný vliv. $\mathrm{V}$ této kapitole se proto zaměříme na způsoby připisování legitimní moci studentovi učitelství cvičným učitelem a poté na proměny legitimní moci v interakci studenta učitelství a cvičného učitele ve třídě před žáky.

\subsubsection{Propůjčení legitimní moci studentovi učitelství}

Pro vstup studenta učitelství do školní třídy je stěžejní osobou cvičný učitel. Cvičný učitel zde hraje roli gatekeepera, tedy toho, kdo otevírá pomyslnou bránu školní třídy, ve které student prožije svoji celosemestrální praxi. Gatekeeper zprostředkovává prvotní kontakt obou stran, tedy představuje určitým způsobem studentovi třídu a představuje třídě studenta učitelství. Způsob představení studenta žákům ve tř́́dě můžeme chápat př́mo jako akt připsání legitimní moci.

\section{Ukázka 3}

Milena: Já jsem se jim nepředstavovala nijak, protože vlastně, když jsem přišla poprvé na ten náslech do té třídy, tak mě představila paní učitelka. A představila mě jako paní učitelku, která se na ně jde podívat, a která tam u nich potom bude i učit.

Tazatel: Jo, takže vás vlastně představila jako paní učitelku, ne jako studentku. Milena: Ehm, jako paní učitelku. Nebo oni teda, ona jim potom nějak řekla, že ještě studuju, ale hlavně mě představila: To je paní učitelka...

Cvičný učitel tedy představuje studenta žákům rolí, kterou bude ve tř́idě plnit, a to je role učitele. Student však nepůsobí jen ve třídě, ale vykonává řadu činností ve škole. Tam se může setkat se žáky, jimž představen nebyl, a kteří tudíž jeho legitimní moc nevnímají.

\section{Ukázka 4}

Lenka: To se mi občas stane, že mám dozor za paní učitelku, protože ona jich má docela dost. Tak to se mi tak stane, že se ve tř́dě válej na zemi, tak to jako zasáhnu.

Tazatel: A reagují?

Lenka: Někdy jo a někdy mně přijdou, že jak mě neznaj. Zase, to jsou ty třídy, kde jsem nikdy nebyla. Kdo to vlastně je, nějaká maminka no, nebo kdo to vlastně je. 
Tazatel: Přestanou nebo koukají a nevědí, jestli přestat?

Lenka: No, nevědí, jestli přestat a pak když jdu zpátky a oni to dělaj zas, a já jim řeknu, že už sem jim to jednou ř́kala, a oni pak jako přestanou. Je tam fakt to, že prostě mě neznaj na tý celý škole, že jsme tam nebyli představeni, třeba ve školním rozhlase, že se tam budeme pohybovat.

Lenka se v této ukázce pohybuje ve škole bez legitimní moci vycházející z role učitele. Namísto ní uplatňuje při dozoru o přestávkách legitimní moc vycházející z role dospělého. Pro Lenku může být nabytí této legitimní moci nové a nevyzkoušené, nebơ jak jsme uvedli v kapitole 1.1.1, Lenka se stejně jako ostatní studenti učitelství ve výzkumném vzorku nachází ve vývojovém období vynořující se dospělosti, pro které je charakteristické vnímání sebe sama někde mezi dospívajícím a dospělým. Legitimní moc dospělého nad dětmi ve škole vyplývá i z této základní nerovnosti ve společnosti (Pratto et al., 2008). Ve škole je však tato nerovnost transformována do podoby nerovnosti učitelů a žákủ. Legitimní moc plynoucí pouze z role dospělého je pro žáky matoucí. Dospělý, který uplatňuje vůči žákům legitimní moc nejčastěji - rodič, jí disponuje v rodině spíše než ve škole. Ve škole je legitimní moc vyhrazena pedagogickým pracovníkům. Pro jiné dospělé, tedy i pro studenty učitelství, je tím pádem legitimní moc ve škole obtížněji naplnitelná. Student se tak může dostat až do experimentální situace výkonu učitelství bez legitimní moci, v níž nemusí uspět. Vnímání vstupu do role učitele je pak u studentů s touto zkušeností provázeno nejistotou, přičemž si nemusejí uvědomit, že jedním $\mathrm{z}$ chybějících předpokladů pro úspěšný výkon role bylo právě uvedení do role a s ním spojené přidělení legitimní moci. Bez legitimní moci nemohou studenti uplatňovat další mocenské báze spojené s rolí učitele a jejich potenciál k ovlivňování žáků je tak nízký. Důsledkem tohoto procesu může být vnímání vlastního selhání v roli, přestože toto selhání není dáno studentem samotným, nýbrž nefunkčním nastavením této role (Lojdová, 2014).

Pokud se však podaří studenta do školy uvést jako někoho, kdo vykonává roli učitele, a pokud k tomu současně přispívá také kultura školy, může student skrze kontakt se žáky svoji legitimní moc snáze vykonávat a percipovat. Takto legitimní moc vnímala studentka Alice:

\section{Ukázka 5}

Tazatel: Ř́kají Vám žáci paní učitelko?

Alice: I na chodbách, když se třeba potkáme, tak, paní učitelko, a budeme dělat tohlecto, a paní učitelko budete nás dneska učit a budeme dneska psát písemku. Stalo se mi, že i třeba žáci z jiných tříd měli před písemkou před angličtinou a najednou za mnou přišel žáček, a paní učitelko a tohlecto, a když to chci dát do minulého času, je to takhle dobře? Takže to bylo takové fajn.

Tazatel: Bylo Vám to jako př́jemné? 
Alice: Jó, jo, určitě. Víc než když by mi říkali nějak jménem, nebo ten člověk získá jakoby takový větší pocit sebevědomí, řekla bych, že k tý škole to asi patř́i.

Studentce Alici jsou projevy legitimní moci od žáků př́ijemné. S těmito projevy je spojené oslovení „učitel“ a také určitá důležitost, kterou tímto oslovením studentka získává. Najednou se stává $\mathrm{v}$ hierarchii školy někým, komu náleží legitimní moc. Ta je zde očividně spojena také s jinými mocenskými bázemi, zejména s mocí referenční a expertní. Žáci ve volném čase vyhledávají studentku učitelství zřejmě také proto, že k ní již mají vytvořen určitý vztah a současně ji považují za někoho, kdo může garantovat správnost odpovědí na jejich otázky.

Kromě explicitní roviny představení studenta žákům třídy je ve vztahu k utváření jeho legitimní moci důležitá také rovina implicitní. Ta zahrnuje to, jak má cvičný učitel nastaveny vztahy se tř́idou, jak přistupuje $k$ výuce předmětu a jaká pravidla ve třídě fungují. Student učitelství proto vstupuje do situace, která je cvičným učitelem předem do určité míry definovaná:

\section{Ukázka 6}

Milena: Ti žáci byli strašně hodní. Až mě to překvapilo, ale oni byli. Paní učitelka má u nich takový si myslím hodně respekt a... Ehm. Hodně jí poslouchají, takže si myslím, že je na mě tak trošku připravila.

Definicí situace cvičnou učitelkou, do které studentka Milena vstoupila, byl avizovaný respekt ke studentce. Opačnou zkušenost má Lenka, jež se potýkala se zvýšenou nekázní žáků v 9. ročníku (studentka praktikovala i ve třídách, které se ve výzkumu nenatáčely), což mohlo souviset s definicí situace u její cvičné učitelky, přistupující k žákům na konci povinné školní docházky volněji.

\section{Ukázka 7}

Lenka: Ale tam je to docela džungle. Mají prostě povoleno to, že koho to nezajímá ((smích)), takže hlavně at neotravujou. Takže tam se mi ani nechce jít učit vůbec.

Takto definovanou situaci může student změnit jen obtížně. Zvláště proto, že se snaží přejít od volného pracovního tempa k intenzivní pracovní atmosfére. Rídit takovou třídu je pro studenta obtížnější a případná selhání studenta pak nemusí souviset jen $s$ jeho vlastním působením, nýbrž s definicí situace ve tř́dě.

Definice situace cvičným učitelem v perspektivě žáků jsme se v dotazníku dotkli položkou Tuhle učitelku poslouchám, protože mi to řekla naše paní učitelka. Nejvyšší hodnotu zde od žáků získala studentka Alice $(\bar{x}=4,00)$, u níž legitimní moc „předpřipravená“ cvičnou učitelkou převažuje nad všemi ostatními položkami 
legitimní moci. Naopak Věra s nejnižší hodnotou v této položce $(\bar{x}=1,93)$ vidí svoje zdroje legitimní moci mimo cvičného učitele. Situaci ve tř́dě charakterizuje v rozhovoru takto: „No všichni mně přišli takoví jakoby klidní, že to tak jako všechno přijímali“. Pohled Mileny, jež výše referuje o tom, že žáci byli hodní kvůli cvičné učitelce, potvrzují i sami žáci. V této položce získala Milena druhou nejvyšší hodnotu $(\bar{x}=3,48)$. Definice situace cvičným učitelem je významná jak v perspektivě studentů, tak i v perspektivě žáků, a to zejména u těch studentů, kteř́ se potýkají s problémy v řízení třídy.

Studenti jsou si tohoto rámce daného cvičným učitelem, který obsahuje nejen způsob uvedení studenta do třídy, ale i rutiny spolupráce, většinou vědomi. Přestože se snaží podat ve třídě co nejlepší výkon, pravidla třídy si netroufají měnit. S pravidly tř́idy tedy studenti na praxi obvykle nepracují, nebơ je vnímají jako daná.

\section{Ukázka 8}

Tazatel: A nastavil jste si Vy nějaká pravidla, která jste chtěl, aby oni dodržovali?

Radek: Ne. Tak jakoby normálně, aby byl klid, aby se vlastně něco dozvěděli, abych jim nějaké vědomosti předal.

Tazatel: Ale jsou to nějaká pravidla, která jste si stanovil Vy?

Radek: Ne, to je tady stanovené.

Tazatel: To, to už tu je...

Radek: Oni jsou na to zvyklí vlastně.

Studenti učitelství tedy mnohdy předpokládají, že jsou ve třídě implicitní pravidla, jejichž dodržování od žáků očekávají. Pokud však chtějí upevnit svoji legitimní moc, mohou př́mo odkazovat na normy, pravidla školy a legitimní moc cvičného učitele. $\mathrm{V}$ dotazníku toto zachytila položka Tahle učitelka naznačuje, že to, co chce ona, podporuje taky naše paní učitelka/učitel, ředitel nebo řád školy. V této položce studenti dosáhli hodnot v průměru od 2,33 do 3,67, nebyly mezi nimi přitom výraznější rozdíly. Odkazování na externí normy a legitimitu druhých je tak relativně běžný způsob, jímž studenti posilují vlastní legitimní moc. Položka také ukazuje, že se požadavky studentů na žáky výrazně neodklání od požadavků cvičných učitelů, kteří ve třídě vyučují běžně.

Kromě implicitních pravidel se v některých tř́ídách studenti setkali is demokraticky utvořenými pravidly školní třídy. Nejčastěji však hovoří o pravidlech vycházejících z morálních norem. Oproti tomu nejméně často akcentují jako zdroj pravidel pro práci ve třídě závazné normy ve škole, jako je školní rád. Školní rád nikdo ze studentů ve výzkumném vzorku nečetl, mnozí ho považují za mrtvou normu. 


\section{Ukázka 9}

Tazatel: A četla jsi třeba školní řád? Je tam třeba k něčemu užitečný?

Lenka: Já myslím, že je na všech školách stejný, abych pravdu řekla. Já jsem zatím nikdy žádný školní řád nepřečetla. Já věřím, že ty děcky taky ne.

Legitimní moc tedy studenti nestaví na formálních normách, které navíc ani mnohdy neznají. Nepostupují ani prostřednictvím demokratických pravidel, nebot' vzhledem $\mathrm{k}$ délce praxe nemají prostor je $\mathrm{s}$ žáky utvářet. Opírají se tedy spíše o normy morální. Jsou to přitom normy, které pravděpodobně studenti zažili v průběhu své školní docházky a nyní je z části neuvědoměle replikují. S normami ve škole mají totiž studenti mnohaletou zkušenost v roli žáků. Na první pohled se tato zkušenost může jevit jako výhoda, protože studenti důvěrně znají prostředí, do něhož vstupují. Na druhou stranu znalost tohoto prostředí může být spojena s určitou rigiditou chápání norem, které ve škole platí. Tyto dlouhodobě prožívané normy pak pro studenty může být obtížnější kriticky reflektovat či přemýšlet o normách nových. Řád tradiční školy (v nehodnotícím smyslu) se tak reprodukuje i skrze začínající učitele, kteří jsou jím „zatíženi“ ze svých školních let. Ilustrují to výroky Karly a Lenky:

\section{Ukázka 10}

Karla: Je to nepsané morální pravidlo, že když mluví učitel, tak by žáci měli mlčet. Takže to je jim nutno občas připomenout. Že když tedy mluví vyučující, tak vy byste měli dávat pozor a až vás vyučující vyvolá, tak máte slovo.

\section{Ukázka 11}

Lenka: No a já bych dodržovala to, abysme se respektovali navzájem, aby tam neprobíhaly žádný vulgarity, agresivita a pak vždycky ř́kám, když tě to nebaví, tak aspoň neruš ((smích)), to se mi občas tak jako povede, no. Na začátku jsme si žádná pravidla nedávali, jako že bych první hodinu věnovala tomu, abychom si dali nějaký pravidla. Já myslím, že už jsou natolik starý (pozn. studentka referuje o žácích 8 . ročníku), aby věděli, jak se maj chovat.

Tyto morální normy studenti předem neošetřují, nýbrž je automaticky předpokládají. K verbalizování normy dochází až tehdy, kdy je porušena. Verbalizace normy však často nebývá doprovázena avizovanou sankcí. Tím se legitimní moc studenta učitelství oslabuje. Ilustruje to ukázka z výuky studentky Alice. 


\section{Ukázka 12}

Studentka Alice vyučuje třetí hodinu občanské výchovy v osmém ročníku

U: Tak, utišíme se. Máte přečtený všechny ty věty? (Dobrý.) Správně jste doplnili? Tak mi řekněte, co je $s$ těmi větami špatně.

DD: (nnn)

U: Zdají se vám normální? Používáte takovéto věty v běžné komunikaci?

D: Ne, protože poškozují toho druhého.

U: (n) Přihlaš se. (Veruš) Prosím.

D: (n)

U: Nahlas musíš.

D: (Věty) poškozují toho druhého.

U: Dobře. Co si o tom myslíte vzadu? Jsou ty věty v pořádku?

Krátká ukázka výukové situace obsahuje tři normy výukové komunikace 1) když mluví učitel, utišíme se, 2) hlásíme se a 3) mluvíme nahlas. Takováto pravidla verbalizují studenti ve výukové komunikaci nejčastěji. Můžeme je chápat jako součást žákovského registru a ilustrujeme je shodně v kapitole 4.4.1.2, na př́kladu studentky Karly. Žákovský registr lze definovat jako očekávané a oceňované formy žákovského komunikačního chování (Šed’ová, 2009). Jako jsou implicitní pravidla žákovského registru, do nichž se žáci musejí socializovat (Šalamounová, 2012), tak jsou implicitní i pravidla morálky školní třídy a socializace do nich pro studenty učitelství začíná už jejich vlastní povinnou školní docházkou. Spíše než o žákovském registru zde hovoříme o pravidlech morálky školní třídy, která jsou širší než pravidla výukové komunikace. Žákovský registr spojujeme s výukovou komunikací, morálku školní třídy s fenoménem moci. Stejně jako se komunikační chování žáků ve škole liší od komunikačního chování v běžném životě, liší se i morálka školní třídy od morálky běžného života. Např́íklad pravidlo hlášení se je příznačné právě pro školní kontext. $\mathrm{V}$ čem se ale shodují pravidla morálky školy i běžného života, je to, že se jedná o regulaci vztahů v určité skupině. Pravidla jsou také většinou nepsaná a na základě nich dochází k hodnocení chování v rozmezí mravné - nemravné. Morální diskurs zahrnující regulaci sociálních vztahů a identit je prritom dle Bernsteina (1990) předpokladem osvojování kompetencí. Socializace do morálky školní tř́dy se týká všech aktérů: žáků, studentů učitelství i učitelů. My se zaměřujeme na studenty učitelství, pro které je socializace do morálky školní třídy procesem spojeným $s$ utvářením identity učitele a procesem stávání se učitelem (becoming a teacher) popsaným v kapitole 1.2.2. Studenti si v rámci morálky školní tř́dy osvojují novou roli učitele i kompetence s ní spojené. Volí spíše přijetí stávajících pravidel než jejich změnu z důvodu, že svoji praxi popisují jako „návštěvu“ ve třídě. Proto si nedovolí zavádět nová pravidla v oblasti regulace vztahů ve tř́́dě a spíše předpokládají implicitní morální normy ve školní tř́ídě či kopírují pravidla nastavená cvičným učitelem. 
Role cvičného učitele jako gatekeepera přetrvává déle než jen v prvním kontaktu se tř́́dou. Zejména přítomnost cvičného učitele ve tř́dě v průběhu studentovy praxe tyto prvotně nastavené podmínky udržuje. Cvičný učitel svou přítomností ,jisti“ studenta učitelství. To se ukázalo zejména v situacích, kdy cvičný učitel ve tř́dě absentoval. Pokud učitel „nekryje studentovi záda“, může se jeho křehká legitimní moc rychle rozplynout. Přestože legitimní moc není jedinou mocenskou bází studenta učitelství, absenci její podpory cvičným učitelem pocítili někteří $\mathrm{z}$ těch studentů, kteří vyučovali ve třídě samostatně.

\section{Ukázka 13}

Alice: Když tam seděla paní učitelka, nikdo neřekl ani slovo, všichni seděli a prostě nekomunikovali třeba $v$ těch dvojicích se sousedy a podobně tak často. Když tam paní učitelka nebyla, tak jak jsem ř́kala, oni se bavili se sousedem, občas se otočili, sem tam něco křili přes třídu a podobně.

Tazatel: Tak to bylo náročnější pro vás.

Alice: Určitě, určitě to bylo náročnější, ale bylo to autentičtější, takže jakoby ta skutečná třída, která prostě nad sebou nemá jakoby tu ruku toho učitele a chovali se tak jako se chovají normálně s tím, že teda já jsem u nich neměla tak velký slovo, protože mě neznali tak dobře, byla jsem tam jenom pár hodin, takže to bylo trochu jiný, a ř́kám, dovolili si víc než k té paní učitelce.

Př́tomnost cvičného učitele ve tř́dě může podporovat legitimní moc studenta. Cvičný učitel prrítomný ve třídě je šedou eminencí, tedy osobou, která má významný vliv na mocenskou situaci ve třídě, přestože do ní většinou přímo a záměrně nevstupuje. Může být nositelem bazální legitimní moci, jež se do legitimní moci studenta učitelství jen promítá. I to může být součástí charakteristiky role, ve které si student učitelství legitimní moc „půjčuje“. Plnohodnotné nastavení legitimní moci zakusí studenti až s plnohodnotným výkonem učitelské role.

Podpora cvičného učitele ze zadních lavic zejména při prvních výukových výstupech přispívá k pozitivnímu vnímání nové role studentem samotným. Aby student mohl legitimní moc vykonávat, je však třeba, aby mu cvičný učitel skutečně předal i související pravomoci.

\section{Ukázka 14}

Lenka: I v tom, že já vystupuju na stejný úrovni jako ta paní učitelka. Ona jim to prostě řekla, že já budu mít stejný pravomoci jako ona, že já jim ty poznámky taky můžu dát, že jim můžu známkovat úkoly. Ona jim jako ř́ká, že jsem ve stejné situaci jako oni, že se taky učím. Zároveň mi dala ty pravomoce jako má ona. Takže oni to prostě vědí, takže.

Tazatel: Takže kdybys chtěla dát poznámku, tak to prostě platí?

Lenka: Jo, jo. 
Tazatel: A už dávalas někdy? Fakt? A za co?

Lenka: Taky jsme pracovali s pracovním listem, on prostě neměl doplněnou ani čárku a to. A furt se tam tak válel a dělal si jiný věci. Tak tomu jsem dala, že jako nespolupracuje, no.

Tazatel: A co on na to?

Lenka: Byl trochu překvapenej, že jsem to fakt udělala.

Tazatel: A prríště?

Lenka: Př́ště to bylo lepší.

Tazatel: Mělo to efekt?

Lenka: Ale jo, myslím si, že ho to překvapilo, všechny to překvapilo.

Z uvedené ukázky vyplývá, že žáci mnohdy nevědí, zdali má student na praxi stejné pravomoci jako učitel. Proto je třeba, aby učitel tyto pravomoci studentovi explicitně předal, a to včetně nástrojů $k$ udělování sankcí, jak negativních (poznámky, špatné známky), tak i pozitivních (pochvaly, dobré známky). Tak se stává legitimní moc studenta učitelství skutečně naplňovanou. Uplatňování legitimní moci skrze odměňování známkováním popisujeme v kapitole 4.4.1.2.

To, zda žáci vnímají studenta jako součást školy, zjištovala položka dotazníku, která se žáků ptala, zda student může či nemůže nějak zasáhnout, pokud se mu nelíbí, jak se některý z žáků ve třídě chová (Když se téhle učitelce nelíbí, jak se chovám, stejně nemůže nic dělat, protože nepatři $k$ nám do školy). $Z$ výsledků vyplývá, že cvičným učitelům se většinou povedlo začlenit studenty do instituce školy. Hodnoty průměru u studentů učitelství se v této položce pohybují od 1,74 do 2,99 . To znamená, že žáci spíše vnímají studenty jako relevantní aktéry vyučovacího procesu a přisuzují jim tudíž legitimní moc.

Jak zaznělo na začátku, legitimní moc se utvárí v průběhu celé praxe, kde může mezi studentem učitelství a cvičným učitelem kolísat. Podíváme se proto podrobněji na legitimní moc v interakci studenta učitelství a cvičného učitele.

\subsubsection{Legitimní moc v interakci studenta učitelství a cvičného učitele}

Tím, že cvičný učitel připíše studentovi učitelství legitimní moc, ji sám neztrácí. Stále může ve tř́́dě mocensky působit, a to nejen ve vztahu k žákům, ale i ve vztahu ke studentovi učitelství, jemuž může legitimní moc dokonce dočasně odebrat. Popíšeme tř̌i komplementární role studenta učitelství a cvičného učitele, které se odlišují mírou proporce legitimní moci studenta a cvičného učitele.

Rolí studenta učitelství s největší mírou uplatňované legitimní moci je role partnera, ke které představuje komplementární roli cvičného učitele také partner. $\mathrm{V}$ tomto typu spolupráce pracuje cvičný učitel se studentem učitelství jako s partnerem, ponechává mu vysokou míru autonomie a nepřebírá nad ním a ani nad jeho činností kontrolu. Výuka je postavena na legitimní moci studenta učitelství, 
přestože legitimní moc cvičného učitele se do ní může promítat implicitně. Role partnera se výrazně projevuje už v př́ípravě na výuku:

\section{Ukázka 15}

Tazatel: Jo a tu Vaši prípravu ale nějak jako kontrolovala nebo... (pozn. cvičná učitelka)?

Milena: Ne. Vůbec. Nebo já jsem tak nějak jí třeba jenom trošku... Ona se mě třeba zeptala nebo přišla, co budeme jako dělat, ale vždycky mě to nechala úplně, jak jsem to vlastně měla nachystané, tak jsem to měla nachystané...

Tazatel: Takže Vám do toho nevstupovala...

Milena: $\mathrm{Ne}$, vůbec nijak.

Pro utváření legitimní moci je však zajímavé podívat se na to, jak je naplňována mezi cvičným učitelem a studentem učitelství před žáky, tedy ve výuce. Takovou zkušenost má studentka Lenka:

\section{Ukázka 16}

Lenka: Nebo třeba tedkka jsme dělali s devátákama, prostě budování socialismu v Československu. Ona (pozn.: cvičná učitelka) to zažila, takže mě jakoby mě doplňovala. Já jsem vždycky řekla tu obecnou větu a ona to doplnila konkrétními př́ílady, jak ona to zažila.

Tazatel: To jste měli tandemovou výuku? Jo? Domluvenou nebo náhodnou?

Lenka: Náhodnou. Taky je to dobrý. Ty děcka poznaj, že ta paní učitelka to opravdu zažila, že to není jen to, že to bylo napsaný v učebnici. Tak to jsme měly takhle.

Student učitelství i cvičný učitel vystupují jako autonomní aktéři, mezi nimiž je rovnocenný vztah, a kteří se vzájemně doplňují. V uvedené ukázce mělo toto doplňování podobu improvizované tandemové výuky. Oba disponují plnohodnotnou legitimní mocí, jeden si ji tedy nepřisvojuje na úkor druhého.

Ve třídě však vyvstane řada situací, se kterými potřebuje student učitelství pomoci. Protože je cvičný učitel ve výuce většinou př́itomen a „kryje studentovi záda“, může v př́ípadě vzniku problémové situace prř́mo zasáhnout skrze legitimní moc, kterou disponuje, i když roli učitele propůjčil návštěvníkovi z pedagogické fakulty. Legitimní moc studenta se v takové situaci oslabuje, vykonává ji za něj učitel. Tuto roli studenta označujeme jako roli tonoucího a komplementární roli cvičného učitele jako roli záchranáře: 


\section{Ukázka 17}

Zdena: Jo ale tedkka jsme si vzpomněla. $V$ devítce, ty téespéčka. Já jsem si je vlastně vypracovala doma a pak jsme je dělala s děckama. A byla ta- a jakoby nenapadlo mě, že děcka by se mě mohli zeptat na něco třeba, co znamená nějaké slovo. Samozřejmě sem to, jako bylo tam. Dám př́klad: cosi odevzdejte v nejzazším termínu, jo. A najednou všichni pracovali a jeden štoural: „Paní učitelko, co to znamená nejzazší?“. Ted’ prostě já jsem to nečekala, ted"ka v nervech. A ted si ř́kám. Úplně jsem zapochybovala, co znamená ten nejzazší, jestli ten nejbližší nebo nejpozdější, jo a ted' si říkám, to je v Prčicích. Tak, děcka, kdo to ví, jo, řekla jsem, kdo ví, co znamená slovo nejzazší. Tak se jeden přihlásil, věděla jsem, že je to chytrolín největší, jo. Si říkám, ten to řekne určitě dobře.

Tazatel: Haha.

Zdena: A potom i cvičná učitelka to vodsouhlasila, jo. Ale jakoby nepočítala jsem, že by se mě mohli ptát i takhle na něco. To jsem neměla připravené. Ještě jak jsem byla ve stresu, tak jsem zapochybovala, jako jo.

Studentka Zdena popisuje výukovou situaci, se kterou si nevěděla rady. Nepožádala sice cvičnou učitelku o pomoc přímo, ale cvičná učitelka možná volání o pomoc vytušila a studentce proto pomohla. Komentář cvičné učitelky podpořil v danou chvíli studentku. Studentkou, která si prrímo řekla o pomoc cvičné učitelky, byla Petra.

\section{Ukázka 18}

Studentka Petra vyučuje ve druhé zaznamenané hodině literaturu. Se žáky sedmé tř́dy probírá básníka, prozaika a dramatika Johanna Wolfganga Goetheho.

U: Byl to básník, prozaik, dramatik.

U: Mám to napsat?

CU: Bylo by to lepší napsat, ne jen to říct.

U: ((piše na tabuli „básník, prozaik, dramatik“))

ŽŽ: ((žáci si píši do sešitu))

Studentka Petra přímo požádala o pomoc cvičnou učitelku, když se jí zeptala, zda má zapisovat na tabuli. Cvičný učitel v roli záchranáře přidává do spolupráce se studentem prvek kontroly, který je studentem přímo či nepřímo vyžádaný. Legitimní moc cvičného učitele tak převažuje nad legitimní mocí studenta, nebở cvičný učitel studentovo rozhodnutí „,autorizuje“.

Ve třetím typu komplementárních rolí je student učitelství označen jako kontrolovaný, tedy někdo, kdo dělá chyby. Cvičný učitel pak ve vztahu k němu hraje roli revizora, tudíž toho, kdo provádí kontrolu. Kontrolním zásahem může cvičný 
učitel legitimní moc studentovi dokonce dočasně odebrat a sám se stát jejím vykonavatelem. Karla popisuje výukovou situaci, do níž jí cvičná učitelka vstoupila tímto způsobem:

\section{Ukázka 19}

Karla: Takže tam je tedko občas problematické tu hodinu vést, když řeknete dvě tři slova a paní učitelka vám do toho skočí, tady jim to připište, že je to důležité. Určitě byste jim to měla napsat. Najednou tam mají dvě paní učitelky před tabulí a ne dobře to asi působí na zbytek třídy.

Cvičný učitel jako revizor může dohlížet na řízení třídy i na didaktickou transformaci obsahu, jak ilustruje uvedená ukázka. Tím, že cvičný učitel vstupuje do silnější kontrolní role, posouvá studenta do role žáka, což může být v rozporu s rolí, kterou student ve třídě hraje, jak bylo uvedeno výše (role učitele). Legitimní moc nezbytná pro výkon role je tak studentovi de facto odejmuta. Zatímco cvičný učitel jako záchranář vstupuje do výukové situace bud' na vyžádání, nebo na základě sdíleného vnímání potřeby pomoci, vstup revizora je studentem nevyžádaný. Studentka Karla tuto situaci vnímá jako problematickou nejen ve vztahu $\mathrm{k}$ sobě, ale i ve vztahu k žákům, pro něž může být tato situace obtížně čitelná. Neznamená to však, že by vstupy cvičného učitele jako revizora nemohly být produktivní. Následující ukázka také z výuky literatury studentky Petry.

Ukázka 20

Studentka Petra vyučuje ve druhé zaznamenané hodině literaturu. Se žáky sedmé trúdy probírá básníka, prozaika a dramatika Johanna Wolfganga Goetheho.

U: Byl členem skupiny Sturm und Drang, což znamená česky „bouře a vzdor“. Tato skupina v té době porušovala všechny možné konvence, jak literární tak společenské.

K: Ou.

CU: Básnická. Děcka, to není hudební skupina. Oni slyší slovo skupina, tak chápou významově, že je to kapela, jo?

U: Jo. ((pripisuje na tabuli))

CU: Je to literární skupina. Umělecká.

Sekvence událostí ve výuce studentky Petry ukazuje, že role tonoucího a záchranáře a kontrolovaného a revizora se mohou střídat nejen mezi vyučovanými hodinami, ale i v rámci jedné vyučované hodiny. Někdy vstupy cvičného učitele jako revizora napomáhají dosahování didaktických cílů, nebot cvičný učitel zná tř́idu lépe než student učitelství. Ona chyba, která charakterizuje roli studenta učitelství jako kontrolovaného, nemusí být ani realizována, může být jen anticipována cvičným učitelem. Student učitelství je ale v tomto rolovém nastavení 
nějakým zpo̊sobem poučen cvičným učitelem přímo před třídou. Kontrolu nad studentem tedy opět přímo před tř́dou přebírá cvičný učitel.

Studenti se v průběhu své praxe většinou setkají se všemi těmito komplementárními rolemi, přičemž může docházet $\mathrm{k}$ jejich proměně $\mathrm{v}$ čase. $\mathrm{V}$ začátcích praxe je častější „revizorské“ zasahování cvičného učitele do výuky studenta, v průběhu praxe se však může nastavení rolí přehoupnout k partnerství. Lenka $\mathrm{k}$ tomu říká: „Do češtiny mně zasahuje třeba na začátku, když jsem diktovala diktáty, prostě že mám pomalejc, že mám víc diktovat čárky, ale to už tedka taky nezasahuje.“

Kromě toho záleží i na charakteristice cvičného učitele. V př́padě Lenky se jednalo o aktivní cvičnou učitelku, pro kterou bylo nejspíš obtí̌̌né neúčastnit se výuky. Studenti přitom postupně vnímají potřebu disponovat legitimní mocí plnohodnotně a vymanit se z kontroly cvičné učitelky.

\section{Ukázka 21}

Lenka: Tak ona už se taky snaží, abych to už zvládla sama. Ale je fakt teda většinou zasáhne.

Tazatel: A myslíš, že bys to nezvládla sama, bez ní?

Lenka: Zvládla, zvládla. Já myslím, že jo, že to by asi stačilo zvýšit hlas víc, než dělám normálně, že.

Legitimní moc je $\mathrm{v}$ případě zásahů cvičného učitele spiše $\mathrm{v}$ jeho rukou než v rukou studenta učitelství. Avšak i v situacích, kdy nastavení rolí podporuje legitimní moc studenta, je stále tato moc podmíněna faktory jako je zmíněná definice situace ve třídě a prítomnost cvičného učitele ve třídě.

\subsubsection{Shrnutí: Neviditelná legitimní moc, bez které to však nejde}

Žáci připsali studentům poměrně nízkou míru legitimní/donucovací moci (průměr pro všech osm studentů ve vzorku je 2,39), což ale neznamená, že se tato báze moci ve školní třídě vyskytuje sporadicky. Zaměříme-li se na legitimní moc, můžeme konstatovat, že ji studenti nezdůrazňují a nepracují s ní explicitně. Legitimní moc je však nezbytným předpokladem vyučovacího procesu. Aby student učitelství mohl v průběhu praxe vyučovat, musí disponovat legitimní mocí. To znamená, že žáci musejí percipovat studentovo „právo“ klást na ně požadavky. Legitimní moc připisuje studentovi zejména cvičný učitel, a to nejprve způsobem, kterým ho představí třídě a dále tím, jak se studentem interaguje před třídou. Nejčastěji studenta představí rolí, kterou bude ve tř́iě vykonávat, tedy rolí učitele. Situace ve školní třídě, do níž student vstupuje, je učitelem předdefinovaná. Jsou zde nastavena určitá implicitní pravidla. Hranice legitimity jsou dány také formálními normami pozice i jinými normami a tradicemi v instituci (Griffin \& Moorhead, 2013). V případě studentů ve výzkumném vzorku to byla např́íklad 
odlišná velikost tř́d, v nichž praktikovali, a to, zda se studenti se žáky znali i mimo praxi. Tak tomu bylo u Radka, který praktikoval na malé škole v místě svého bydliště. Ve třídě bylo 7-11 žáků. Bližší vztah měl Radek i s cvičnou učitelkou: „A tady, tady s paní učitelkou se známe dlouho. Vlastně už od té základky vlastně a, a ona taky není o moc taky starší než já takže mi nabídla tykání. Si tykáme.“ (Radek). Radek pritom tato specifika hodnotí jako pozitivum pro výkon praxe. Mohou se promítnout i do výkonu moci ve školní tř́dě, zejména legitimní a referenční.

$\mathrm{Na}$ začátku je to cvičný učitel, kdo legitimní moc předává, dále je to student, na kom legitimní moc leží. Cvičný učitel však tímto předáním legitimní moc neztratil, naopak může do situací ve tř́iě z této mocenské pozice stále vstupovat, a posilovat nebo oslabovat tak legitimní moc studenta. To odpovídá definici moci v kapitole 2.5.1, kde jsme uvedli, že moc není pevná komodita, již někdo vlastní a může ji rozdělit jako koláč, nýbrž je to mnohočetná všudypřítomná síla, která tvaruje vztahy ve školní třídě. Legitimní moc se naplňuje požadavky každodennosti, jako je práce s časem, výběr učiva, řízení třídy atd. (Richmond \& McCroskey, 1992). Legitimní moc studenta se posiluje tehdy, když osoby podřízené této moci vnímají její smysluplnost a to, že moc bude využita v jejich zájmu (Weller \& Weller, 2002). Jestli žáci vidí výkon moci jako legitimní, pak se jí podřizují, a to i tehdy, když se jim př́kazy nelíbí, protože to považují za vhodné (Spoelstra \& Pienaar, 1999). Zde se otevírá prostor pro motivování žáků cvičným učitelem a vysvětlování benefitů, které jim může spolupráce se studentem přinést (napr. nové pedagogické prrístupy). Jak upozorňuje Felix (2011), pokud žáci učitele respektují, spíše je bude učení bavit a více se toho naučí. Legitimní moc je tak př̀edpokladem naplňování didaktických cílů ve výuce. Později, kdy držitelé legitimní moci znají potřeby vedených, jejich dispozice a aspirace, může být legitimní moc nahrazována jinými mocenskými bázemi (Weller \& Weller, 2002).

$\mathrm{V}$ počátcích praxe jsou však různé podoby utváření legitimity studenta učitelství ve školní třídě klíčové pro funkční výukový proces. Zaměřili jsme se proto na způsob, v němž členové sociálního systému přijímají určité formy legitimity (srov. Clegg \& Haugaard, 2009). Cvičný učitel legitimizuje studenta jako aktéra mimo instituci školy, který v ní může dočasně vykonávat roli učitele. V rolovém nastavení studenta učitelství a cvičného učitele partner - partner je legitimní moc rozdělena mezi oba dva aktéry, ale jeden jí nedisponuje na úkor druhého. $\mathrm{V}$ komplementárních rolích tonoucí - záchranár a kontrolovaný - revizor legitimní moc získává cvičný učitel na úkor studenta, $\mathrm{v}$ prvním případě s vyžádáním studenta, a ve druhém bez jeho vyžádání. Tyto komplementární role studenta učitelství a cvičného učitele jsou ovlivněné nejen fází praxe, ale jsou také podmíněné situačně. Pro funkční nastavení spolupráce cvičného učitele a studenta učitelství je třeba, aby podoba jejich spolupráce byla vyjednaná a aby její průběh byl reflektovaný. K zamyšlení studentů i cvičných učitelů nad tím, jak spolupracují, by mohla sloužit i tato kapitola. 


\subsection{Donucovací báze moci aneb Dobrý učitel má vše pevně v rukou}

Josef Lukas, Kateřina Lojdová

V předchozí kapitole jsme naznačili, že legitimní a donucovací moc k sobě mají velmi blízko (ve výstupech z kvantitativních dat našeho výzkumu dokonce tvoří jeden faktor - viz kap. 4.1). V kvalitativních analýzách se však tato „spočítaná jednoznačnost“ jeví poněkud odlišně, protože každá ze zmíněných bází moci má své specifické projevy. Proto se v následující kapitole pokusíme podrobněji charakterizovat různé podoby donucovací moci v jejích různých kontextech a návaznostech na ostatní báze moci.

\subsubsection{Donucovací moc ve školním kontextu}

Jak bylo zmíněno v kapitole 2, donucovací moc (báze moci) učitele obecně vychází z žákovy potřeby vyhnout se trestu, který ovšem může nabývat mnoho různých podob. Jelikož již byla ve druhé kapitole diskutována neutralita pojmu moc, tak na tomto místě pouze zdůrazníme, že sám o sobě lze chápat neutrálně i pojem donucovací moc - můžeme jej tedy naplnit pozitivním i negativním obsahem (srov. Šed’ová, 2011). Donucovací moc proto nelze a priori spojovat s negativními konotacemi, vždy záleží na kontextu a vhodnosti jejího užívání. V některých výpovědích námi zkoumaných studentů učitelství se ukázalo, že donucovací moc (právě v souvislosti se zažitými kontexty slova „donucovat“) vnímají spíše v negativním smyslu - např.: „Donucovací moc uplatňuji velmi sporadicky až ve chvílích naprosté krize a je mi to velmi nepř́ijemné. Většinou nějakým způsobem apeluji na žáka a snažím se mu vysvětlit, že překračuje určité hranice a nelíbí se mi, jak se chová, argumentuji (ale snažím se vyslechnout i jeho)“ (Věra, reflektivní deník). Také z výsledků kvantitativní části našeho výzkumu (dotazník Báze moci) vyplynulo, že vnímání donucovací báze moci zkoumaných studentů učitelství jejich žáky nebylo přiliš velké, což se projevilo právě u Věry, která měla u donucovací báze moci hodnotu nejnižší (srov. kapitola 4.1).

$\mathrm{Na}$ základě naplnění didaktických cílů a vnímání donucovací moci aktéry školní reality uvažujeme o vhodně a nevhodně využívané donucovací moci. Učitelem vhodně použitá donucovací moc přitom mủže žákům pomoci regulovat vlastní aktivity, a přispět tak $\mathrm{k}$ jejich pozitivnímu vnímání klimatu školní třídy a také $\mathrm{k}$ lepším studijním výsledkům. Naopak donucovací moc využívaná nevhodně může ovlivnit klima tř́́dy a proces učení negativně, v tomto kontextu lze hovořit také o nevhodném chování učitele (srov. Mareš, 2013b). Nevhodně využívaná moc zahrnuje například sarkasmus, kř̌ik ve zlosti, urážení žáků a přísné 
tresty. Takové projevy učitele mohou vyvolávat negativní pocity žáků vzhledem k učiteli, úzkost nebo strach u žáků (Mainhard, Brekelmans, \& Wubbels, 2011). Jak jsme zmínili již výše, např. Lewis (2001) připomíná, že ve školní třídě může být dosaženo pozitivních výsledků nejen důrazem na poslušnost a donucování, ale i vyjednáváním se žáky. Právě vyjednávání se žáky patří k vhodnému využití šířeji chápané donucovací moci, kdy učitel je za pomoci persuaze, jakožto přesvědčování o něčem, schopen vyvolat u žákủ žádoucí změny v chování. Pro persuazi je typické, že učitel sice chce přimět žáky, aby jednali v souladu s jeho představami, ovšem na straně žáků existuje v průběhu vyjednávání stále jistá možnost svobodně se rozhodnout, do jaké míry návrhy učitele přijmou. Grác (1988) uvádí, že persuaze je jednou z nejvýznamnějších metod mezilidského ovlivňování. Ve výsledku tohoto procesu se přesvědčovaný dobrovolně přikloní $\mathrm{k}$ názoru původce sdělení. Přesvědčování je nenásilné, založené na relativní svobodě rozhodnutí. I proto, že je persuaze výraznou komponentou donucovací moci, nelze donucování chápat a priori negativně.

V návaznosti na předchozí kapitolu o legitimní moci je třeba zmínit jednu skutečnost, a tou je provázanost legitimní a donucovací moci - donucování totiž vyžaduje určitou legitimitu toho, kdo donucuje. Výsledky prezentované v této kapitole tak spíše zachycují situace, kdy je donucovací moc relativně dobře rozpoznatelná a do jisté míry převažuje nad ostatními bázemi moci (stejně jako tomu bylo v kapitole o legitimní moci).

Na úrovni analýzy videozáznamů z jednotlivých vyučovacích hodin, částečně doplněných jednak o data $\mathrm{z}$ kvantitativní části výzkumu, jednak o údaje $\mathrm{z}$ rozhovorů $s$ našimi participanty (př́padně i o výpovědi studentů $\mathrm{z}$ jejich pedagogických deníků z praxe), se v našem výzkumu objevovaly určité projevy a typy donucovací moci. Nejprve proto představíme typologii projevů donucovací moci, kterou jsme ve výuce našich studentů učitelství na praxích identifikovali, a poté se zaměříme na uspořádání typů donucovací moci do určitých struktur (sekvencí). Některé z těchto sekvencí interakcí mezi učitelem a žáky lze zobecnit snadněji a popsat pomocí tzv. IRF struktury komunikace (viz kapitola 4.3.3). V další části kapitoly zdokumentujeme méně časté a spíše parciální projevy chování našich participantů při užívání donucovací moci, které budeme nazývat miniscénáři. Zde jsme se inspirovali mimo jiné poznatky transakční analýzy, která popisuje interakce mezi lidmi jednak pomocí her, jakožto souvislého sledu transakcí, směřujících k určitému cíli (Berne, 1997), jednak pomocí zmiňovaných miniscénářů. Ty jsou v pojetí Kahlera a Caperse (1974) chápány jako sekvence chování, trvající několik minut či dokonce sekund, jež posilují určité „životní vzorce“, v našem př́padě tedy úžeji vzorce práce učitele se tř́́dou. 


\subsubsection{Projevy donucovací moci a jejich typologie}

Na základě analýzy dat $\mathrm{z}$ realizovaného výzkumu lze hovořit jednak o nejčastějších projevech donucovací moci v chování zkoumaných studentů učitelství na praxích, jednak o určité typologii donucovací moci. Jedním z nejvýraznějších projevů donucovací moci, která logicky úzce souvisí s mocí legitimní, se ukázalo být vyvolávání žáků, což vyplývá mimo jiné i z povahy interakce mezi učitelem a žákem, kde iniciátorem interakce je učitel - vyvoláváním vlastně ve většině situací učitel nutí žáka $\mathrm{k}$ interakci. Záleží však vždy na kontextu, nebot vyvolávání může být i projevem odměňovací moci ve chvíli, kdy se žák vehementně hlásí a usiluje o to být vyvolán (viz kapitola 4.4.1.2). Druhým výrazným projevem donucovací moci je řízení třídy prostřednictvím ukázňování žákư, které opět souvisí s mocí legitimní a je i projevem regulativního diskursu práce učitele se třídou a jemuž se podrobněji budeme věnovat $\mathrm{v}$ kapitole 4.3.4.

Při vytváření typologie jsme vycházeli $\mathrm{z}$ dělení moci na donucovací verbální a neverbální, př́mou a nepřímou, kdy z kombinace těchto kritérii vznikají základní typy donucovací moci. Verbální donucovací moc využívá verbální komunikační prostředky, neverbální donucovací moc pak komunikační prostř̌edky neverbální. Přímá donucovací moc je nejčastěji zacílena na konkrétního žáka, zatímco neprrímá donucovací moc je zaměřena neosobně, tedy většinou směrem $\mathrm{k}$ celému tř́́dnímu kolektivu.

Tabulka 6

Typologie donucovací moci

\begin{tabular}{|c|c|c|}
\hline Donucovací moc & Př́má & Nepř́má \\
\hline Verbální & $\begin{array}{l}\text { Donucovací verbální přímá } \\
\text { Příklad: Slovní vyvolání žáka }\end{array}$ & $\begin{array}{l}\text { Donucovací verbální nepřímá } \\
\text { Př́iklad: Neadresná výzva ke třídě }\end{array}$ \\
\hline Neverbální & $\begin{array}{l}\text { Donucovací neverbální přímá } \\
\text { Příklad: Vyvolávání žáka never- } \\
\text { bálně }\end{array}$ & $\begin{array}{l}\text { Donucovací neverbální nepřímá } \\
\text { Příklad: Čekání na odpověd' }\end{array}$ \\
\hline
\end{tabular}

Základem studentského repertoáru donucovací moci je tedy především vyvolávání, nebở studenti učitelství na praxi se snaží interagovat se žáky v relativně krátké době a bez vytvoření hlubšího vzájemného vztahu, což mohou studenti realizovat právě skrze vyvolávání. Ve vyvolávání je skryt potenciál k donucování, nebot' $\mathrm{v}$ prrípadě, že žák nechce nebo neumí odpovědět, hrozí mu trest.

$\mathrm{V}$ našem výzkumu bylo nejčastějším projevem donucovací moci učitele vyvolání žáka slovy: „Tak jo. Co třeba tebe napadá?“ Specifikem u některých studentů učitelství (jak se ukázalo i v našem výzkumu) je, že žáka zřídka vyvolávají jménem, protože $\mathrm{z}$ důvodu jejich poměrně krátkého působení ve tř́iě jména 
žáků neznají a nevytvořili si ani systém, jak jména žáků využívat ${ }^{28}$. Tento způsob vyvolávání žáků je méně osobní než užívání jejich křestních jmen. Vyvolávání žáků většinou neprobíhá pouze verbálně, ale doprovází ho neverbální komunikace. Donucovací verbální př́má moc je tak doprovázena projevy donucovací neverbální přímé moci: „Prosím?“ ((vyvolá dívku pohledem)). Donucovací verbální nepřímá moc je neadresná, zaměřená na celou třídu. Příkladem takového užití donucovací moci je výrok studentky Alice: „Dneska spíte, dneska se mnou nebudete spolupracovat?" Donucovací neverbální nepřímou moc pak může reprezentovat např́klad využití ticha $\mathrm{v}$ situaci, kdy studentka čeká na odpověd' od žáků (srov. Lojdová \& Lukas, 2015).

\subsubsection{Donucovací moc v IRF komunikační struktuře}

S ohledem na aktuální české výzkumy komunikace ve škole (srov. Šed’ová, Švaříček, \& Šalamounová, 2012) lze na obecné rovině uvažovat, v souladu s daty z našeho výzkumu, o fungování donucovací moci studentů učitelství v konkrétní základní struktuře. Ta odráží typickou podobu komunikace mezi učiteli a žáky, označovanou jako IRF struktura (Iniciace - Replika - Feedback) (podrobněji viz Šed'ová, 2012) ${ }^{29}$. V IRF komunikační struktuře se pochopitelně projevují všechny báze moci, nicméně některé jsou více patrné, především legitimní, donucovací a odměňovací moc. Udržování IRF struktury lze chápat jako projev legitimní moci, ve kterém se odehrává odměňování (viz kapitola 4.4) či donucování, na které se zaměřujeme $\mathrm{v}$ této kapitole. Je ale také třeba podotknout, že koncept IRF struktury nesvede postihnout celou šiři komunikace mezi učiteli a žáky. IRF strukturu lze chápat jako model výrazně redukující složité a bohaté děje v interakci učitele a žáků do Skinnerova neobehavioristického schématu stimul - reakce - zpevnění. Právě trestání a odměňování je však pro tento model typické (úvaze o donucovací bázi moci ve vztahu k behaviorismu se věnujeme také v kapitole 5). Nyní zúžíme pohled na souvislost IRF struktury a donucovací bázi moci.

Na souvislost IRF struktury komunikace a využívání donucovací moci lze nahlížet vícero způsoby, protože zkoumaní studenti učitelství z jednoho úhlu pohledu využívají donucovací moci k nastartování IRF komunikační struktury. Možnost uplatnit donucovací moc je tedy předpokladem rozehrání této struktury, ovšem platí i opačný pohled, protože IRF struktura zároveň umožňuje využívání donucovací moci, což naznačuje např. Šedová (2011, s. 31): „Komunikační struktura tak vytvárí jasné mantinely, jimiž je řízeno chování učitele a žáků a zároveň jsou regulovány vztahy mezi nimi. IRF struktura totiž jasně determinuje situaci, kdy učitel

28 Výjimkou byla studentka Lenka, jíž cvičná učitelka připravila na lavice lístečky se jmény žáků, které po každé studentčině hodině žáci schovali do skříně a před její výukou je zase nachystali.

29 V tomto textu vztahujeme IRF strukturu k učiteli, nebot’ se zabýváme nižším sekundárním vzděláváním. Ve vyšších stupních vzdělávání však může být tato struktura doménou studentů, kteří kladou otázky učitelům či s nimi polemizují. 
určuje, kdo a o čem bude hovořit... Při zachovávání této struktury tedy učitel nepotřebuje usměrňovat žáky explicitními povely typu „odpověz mi na otázku“, nebo "neskákej mi do řeči“, protože rutinizovaná struktura sama o sobě udržuje žáky konformní s požadavky učitele. V následující ukázce je patrné, že při dodržování IRF struktury studentka s využíváním donucovací moci nemá problém.

\section{Ukázka 22}

Milena vyučuje druhou hodinu v rámci výzkumu. V občanské výchově v osmém ročníku se zabývá životním prostredím.

U: Tak to by byl test. (.) A vzpomínáme si, že včera jsme si rríkali, jak se jmenuje ten obor. Měli jsme ho tu dokonce i napsaný na tabuli. Eee který se zabývá ochranou životního prostředí? (1) Tak Dominiku? iniciace

\section{K Dominik: Ekologie. replika}

U: Ekologie správně. (1) Tak to by bylo k té včerejší hodině ještě. A my přejdeme tedkka k našemu dnešnímu tématu. Určitě jste si všimli tady toho nápisu Život v regionech. Takže se budeme zabývat hodně Českou republikou a Brnem. A tady vidíte mapu České republiky. A vy už jste si určitě říkali, na kolik krajů se republika dělí. (.) feedback Vzpomíná si někdo? iniciace

(2)

U: Filipe? iniciace

K Filip: Čtrnáct. replika

U: Čtrnáct, správně. Tak a my si tedka postupně ty kraje ukážeme. Oni jsou tady i na mapě akorát nejsou popsané. feedback Takže napadá někoho nějaký kraj? Název kraje, Sáro? iniciace

D Sára: Jihomoravský. replika

U: Tak pojd' nám ho ukázat.

(2)

U: Správně to je Jihomoravský kraj. feedback Kluci? iniciace

K: Praha replika

U: Praha taky. feedback

(3)

U: Ta je tam, ahm. Filipe? iniciace

K Filip: Středočeský kraj. replika

U: Taky, pojd' nám ho ukázat. feedback

(2)

((šum, rána))

ŽŽ: Pššt.

U: Ahm.

U: Tak nějaký další vás napadá ještě? iniciace

(2)

U: Lukasi, napadá tě nějaký kraj? iniciace 


\section{K Lukas: Nee. replika}

U: Filipe, (.) taky ne? feedback/iniciace

U: Co Simča? iniciace

D Simča: Brno? replika

(1)

U: To není kr-To říkala Sára, to je Jihomoravský kraj tady ten. feedback

U: No můžeš. iniciace

K: Jihočeský. replika

U: Ano. (.) Pojd' nám ho ukázat. feedback/inicicace

K: Já nevím. replika

(2)

U: No tady tento je přímo Jihočeský. feedback

Využívání IRF struktury komunikace ve tř́ídě můžeme tedy chápat jako relativně typický projev donucovací moci. Když se na tomto místě podíváme na data z kvantitativní části našeho výzkumu, tak agregovaná báze donucovací a legitimní moci je u studentů učitelství nejnižší ze všech bází moci (průměr 2,39 - viz předchozí kapitola, obrázek 5 a 6 , s. 61 a 64), což ovšem neznamená, že studenti učitelství donucovací mocí nedisponují. Někteří z nich jsou již schopni využívat tuto moc rutině, přirozeně pro školní prostředí, a tím i neviditelně. Lze to ilustrovat na prríkladu studenta Radka, jehož vyučovací hodiny jsou charakteristické pevnou IRF komunikační strukturou, a který od žáků získal nižší hodnotu legitimní/donucovací moci, než je průměr $(\bar{x}=2,16)$. Skrze kvalitativní data to můžeme interpretovat tak, že Radek si natolik osvojil běžnou IRF komunikační strukturu ve vyučování, že žáci aspekt donucovací moci v jeho hodinách téměř nevnímají. V Radkových hodinách není prostor pro širší diskusi se žáky, a tím i pro potenciálně obtížnější situace řízení třídy, v nichž je třeba žáky ukázňovat, a tím využívat donucovací moc explicitně.

Naopak nejvyšší míru legitimní/donucovací moci připsali žáci Alici $(\bar{x}=2,99)$, která se snažila s žáky diskutovat a vést výuku velmi liberálně, což bývá často dáváno do souvislosti $s$ větší vstřícností studentů učitelství i začínajících učitelů $\mathrm{k}$ žákům (srov. kapitola 1.2.1). Alici se však tento př́istup z různých důvodů př́liš neosvědčil. Ve vyučovacích hodinách bylo patrné narůstání nekázně. Studentka $\mathrm{v}$ důsledku nezvládnutí ŕízení třídy musela paradoxně ustoupit ze svého liberálního pojetí role učitele a žáky neustále ukázňovat. IRF struktura tak u některých začínajících učitelů i studentů učitelství, kteří nemají zažitu „rutinizovanou“ podobu komunikace, vždy neprobíhá „hladce“ jako ve výše uvedené ukázce z hodiny studentky Mileny či u Radka. Právě tehdy, když se učiteli IRF strukturu nedaří udržet, se projevy donucovací moci zviditelňují. Příkladem situací ve výuce, kdy dochází k jakémusi „rozpadu“ IRF struktury může být gradace donucovací moci a rezignace na donucovací moc, jež se často projevovaly právě u Alice. 


\subsubsection{Gradace donucovací moci a její důsledky}

Gradace donucovací moci spočívá ve stupňování nátlaku z pozice učitele, který není s to základy IRF struktury udržet. Ke gradování dochází postupem od uplatňování nepř́mé moci $\mathrm{k}$ moci prŕmé, od neverbální moci $\mathrm{k}$ moci verbální. Tato gradace není pouhou kumulací přímé a verbální moci, protože učitel samozřejmě v určité míře stále využívá i moc nepř́ímou a neverbální. Pomocí situace gradace moci se pokusíme nahlédnout na takovou sekvenci interakce ve školní třídě jako na celek a interpretovat její dynamiku. Ukázku gradace moci přinášíme $\mathrm{z}$ hodiny občanské výchovy, kde se studentka učitelství Alice snaží získat od žákủ odpověd' na otázku, co jsou to city:

Ukázka 23

Alice vyučuje svoji první hodinu v rámci výzkumu. V osmé třídě je přítomno 6 dívek a 5 chlapců. Tématem hodiny jsou city. Učitelka se dle vlastnich slov věnuje rozdělení citů a jejich vlivu na náladu. Téma začiná otázkou, jak by žáci svými slovy vysvětlili, co jsou city.

D: Bolest, radost, smutek.

U: Uhm, výborně. (1) Vzadu, napadá vás něco, když se řekne city? Co byste si asociovali, když řeknu city. Moje city.

K: Asociovali...

U: ((čeká na odpověd)) donucovací neverbální nepř́má moc

U: Dneska spíte, dneska se mnou nebudete spolupracovat? ((usmívá se)) donucovací verbální nepřímá moc

Tak jo. Co třeba tebe napadá? donucovací verbální přímá moc

(2) ((ukazuje na kluka v první lavici u dveří)) donucovací neverbální př́ímá moc

Jak se cítíš třeba ted. donucovací verbální přímá moc

K: Hroznè.

U: Prosím? donucovací verbální přímá moc

K: Hrozně.

U: Hrozně? donucovací verbální přímá moc

K: Dobře.

U: Dobře. Tak jo. Takže poprosím nějak vysvětlete, co to city jsou.

V uvedené ukázce se studentka učitelství snaží získat odpověd’ na svoji otázku. Po položení první otázky začíná donucovací neverbální nepřímou mocí, kdy jen čeká na odpověd’ od třídy. Jedním z důvodů, proč odpověd’ nepřichází, může být použití cizího slova v otázce. Předpoklad, že žáci slovu „asociovat“ nerozumí, může potvrzovat jeho zopakování žákem. Na tento podnět ale studentka Alice nereaguje, soustředí se na odpověd’ na svoji otázku, která nepřichází v čase, jenž 
Alice pro odpověd’ vymezila. Proto pokračuje neadresnou výzvou ke tř́dě, kterou interpretujeme jako nepř́mou verbální moc. Protože ani ta nenaplňuje očekávání studentky učitelství, přechází ke kombinaci donucovací verbální přímé a neverbální př́mé moci, když změní adresáta na konkrétního chlapce v první lavici. Ani zacílení donucování za pomoci vyvolání žáka nepřináší na otázku odpověd', takže studentka volí další verbální podobu moci skrze otázku na žáka, jak se právě cítí. Moc v této ukázce gradovala od nepřímé (celá třída) k přímé (žák) a od neverbální $\mathrm{k}$ verbální podobě. $\mathrm{V}$ uvedené ukázce žák studentce učitelství po peripetii donucovací moci poskytl očekávanou odpověd’. Možné důsledky využití tohoto mocenského scénáře však mají řadu podob. Ilustrujeme je na dalších ukázkách hodin vyučovaných téže studentkou.

Je zřejmé, že gradace působí na všechny žáky ve třídě, at je zacílena př́mo na ně nebo ne. Gradace především vytváří určité napětí, jež subjektivně vnímají nejen žáci, ale samožrejmě i učitel. Jedním $\mathrm{z}$ možných důsledků gradovaného napětí pak může být to, že se přihlásí jiný žák, než na kterého byla donucovací moc původně cílena. Další z hodin občanské výchovy studentky Alice tuto situaci ilustruje.

\section{Ukázka 24}

Ve třetí zaznamenané hodině občanské výchovy se studentka učitelství Alice věnuje tématu člověk $v$ sociálních vztazích. Ve třídě je prítomno 10 žáků, 6 divek a 4 chlapci.

U: Ehm. (.) Dobře. ((jde ke svému stolu a ukáže na žákyně v první lavici))

U: Tak (.) holky, kdy třeba vám se stává, že se nemůžete k něčemu vyjádřit? $(($ šum $))$

U: Žádný nápad? Vždycky máte co říct? (2) Ehm, stalo se v((divka u dveři se hlásí))

U: Prosím ((dá slovo hlásící se dívce))

D: Třeba myslíme na hodně věcí naráz a nemůžeme jako zdůraznit, která z nich je vlastně nejdůležitější.

U: Ehm, výborně. To je asi tvưj př́ípad, že.

D: Jo. ((usmívá se))

Alice zde získala odpověd, jež očekávala, byt’ od jiného žáka, než na kterého původně cílila. Nátlak gradace působil na všechny žáky (nejen na vyvolaného). Může se tedy stát, že na sebe donucovací moc učitele vztáhne některý z žáků, na něhož není př́ímo cílena. Projeví se to například, když se přihlásí někdo jiný než ten, na koho je nátlak vyvíjen. Další možnou interpretací je, že gradace dává př́ležitost žákům, kteři se prostě přihlásit chtějí (a náš koncept gradace donucovací moci se tak vlastně transformuje do miniscénáře moci odměňovací - viz kapitola 4.4). Původní adresát gradované moci zůstává v tomto př́padě v pasivní rezistenci (srov. Lojdová, 2015). 
V prvním př́ípadě situaci gradace moci přerušili samotní žáci, ovšem jindy může gradaci přerušit sám učitel. Jak jsme uvedli výše, gradace moci působí také na učitele a může být pro něj samotného subjektivně nepř́ijemná. Učitel totiž může užití donucovací moci stupňovat jen do určité míry, protože jeho prostředky gradace jsou značně limitované. Situaci může vyřešit tak, že přestane cílit na jednoho žáka a uplatní donucovací moc na žáka jiného. $V$ hodině občanské výchovy tuto strategii studentka Alice uplatnila, když se jí od žáka nedařilo získat odpověd’ na svoji otázku:

\section{Ukázka 25}

Ukázka je taktéž ze třetí hodiny občanské výchovy u studentky Alice. Žáci diskutují nad obrázkem hosta a číšnika, kde se host chová agresivně.

U: Co byste dodali o tom číšníkovi? ((podívá se na pasivní chlapce ve čtvrté lavici u okna)) Kluci zkuste vzadu. Co byste řekli o číśníkovi, jak se chová číšník?

David: ((podívá se do učebnice)) Bojí se.

U: Bojí se čeho?

David: O místo.

U: Proč?

David: Protože ho ch-.

U: Prosím?

David: Já nevim. ((mluví velmi nezřetelně))

U: Zopakuj to nahlas, prosím tě.

((žák neodpovídá, učitelka dá slovo pasivním dívkám v první lavici u okna))

Zatímco v předchozí ukázce užití donucovací moci uzavřeli žáci, v tomto př́ípadě „neúspěšnou“ IRF strukturu související s donucovací mocí ukončila sama studentka Alice. Jelikož žák, na kterého byla gradace cílena, setrvává v pasivní rezistenci, učitelka ve vztahu k němu gradaci vzdává a zaměřuje se na jiné žáky.

\subsubsection{Rezignace na donucovací moc a její důsledky}

Opačnou strategií ke gradaci donucovací moci učitele může být situace, kdy učitel na svoji donucovací (a částečně i legitimní) moc rezignuje, přičemž rezignace na donucovací moc je typicky ilustrována neukončenou sekvencí. Učitel „nedotáhne“ svůj záměr do konce, nechá např́íklad téma bez komentáře. Na rozdíl od gradace učitel postupuje spíše od moci prímé (v ukázce zacílené na žáka Davida) $\mathrm{k}$ moci neprímé (zacílené na celou třídu). V hodině občanské výchovy Alice rezignovala na možnost využití donucovací moci, když upustila od vyústění komunikační situace, ke kterému chtěla původně dojít: 


\section{Ukázka 26}

$V$ další ukázce z občanské výchovy studentka Alice se žáky diskutuje př́klady agresivního chování. Žák vnesl vlastní přiklad, který učitelka rozvijí.

K: Když dotyčná osoba kope nějakou holku do židle, tak se stane agresivní očividně.

((dvě divky z řady u dveři se otáčejí dozadu a smějí se))

U: Kdo se stane agresivní? donucovací verbální př́ímá moc

K: Ta dotyčná holka.

U: A ten dotyčný, který jí kope do židle, agresivní není? donucovací verbální přímá moc

K: Očividně ne. ((směje se))

((dívky se smějí))

U: Tak máte někdo na to jiný názor (.) na tuto situaci? (3) Myslíte si, že agresivní je jenom ta dívky na židli? donucovací verbální nepřímá moc

DD: Jo!

U: Jo (1) á (2) Tak když se vrátíme, když se vrátíte zpátky k té situaci v restauraci. rezignace učitele

V předložené ukázce žáci odpověděli jiným způsobem, než studentka Alice očekávala, když za agresora označovali dívku z ukázky, nikoliv chlapce. Přesto je zde třeba poznamenat, že moc učitele se nevytrácí, protože je to vždy učitel, kdo má více zdrojů k tomu, aby ji centralizoval do svých rukou (Šed’ová, 2015). V uvedené ukázce se to projevuje rezignací studentky učitelství na přesvědčování žáků v diskutovaném tématu, avšak namísto toho využila studentka učitelství svoji mocenskou pozici k tomu, aby otevřela jiné téma. Zároveň se zde ukazuje i možná podoba moci žáků jako provokace učitele. Žáci mohou získat nad učitelem převahu i tím, že záměrně odpovídají nesprávně, přičemž si učitel nedokáže s touto situací poradit a na didaktické cíle tak případně rezignuje.

Zajímavé je, že zatímco v didaktickém diskursu si studentka Alice dovolí na donucovací moc rezignovat a ponechá žákovi jeho názor (či přejde provokativní odpověd), který je odlišný od cílů učitele (ukázka 27), v regulativním diskursu spojeném s řízením třídy se scénáři rezignace důsledněji brání. To se děje skrze intenzivní využívání různých způsobů ukázňování (nap̌r. „Ale holky tiše, neslyším“; „A posloucháme všichni prosím“) a odkazování na normy (např.: „Ale hlásíme se“; „Tiše, tiše ale! NEPŘEKŘIKUJEME SE! Mluví vždycky jenom jeden"). Donucování tak Alice praktikuje důsledněji ve vztahu k pravidlům chování ve třídě než ve vztahu k naplnění svých didaktických cílů. 


\section{Ukázka 27}

Studentka Alice se snaží žákưm vysvětlit odlišný význam dvou různě formulovaných vět. Žákyně na to však nepřistupuje a učitelka jí její názor ponechává.

D: Je to stejné.

U: Je to stejné? (2) Dobře. Pokud si myslí̌s, že je to stejné, tak to nech být.

Zmíněný rozdíl lze interpretovat tak, že pro začínajícího učitele je stěžejní uřídit třídu a snaha o přestavbu prekonceptů žáků je až krokem následným (z jeho aktuálního pohledu zbytným) - což vlastně naznačuje, že regulativní diskurs je vždy nadřazen didaktickému. Se zaměřením na řízení třídy tak do pozadí ustupuje vzdělávací obsah, nebot pokud učitel „nezvládne“ třídu například z hlediska kázně, obtížně naplňuje svoje didaktické cíle.

\subsubsection{Miniscénáře donucovací moci}

V této podkapitole navazujeme na předpoklad, že IRF komunikační struktura, provázaná $s$ vnímanou donucovací mocí učitele, je poměrně častou strukturou využívanou učiteli a $\mathrm{v}$ některých situacích také studenty učitelství $\mathrm{k}$ naplňování didaktických cílů i $\mathrm{k}$ řízení tř́́dy. Ovšem studentům učitelství na praxi se občas nedaří tuto strukturu udržet a povaha jejich interakcí se žáky může mít podobu výše popsané gradace nebo rezignace na donucovací moc.

V některých situacích ve třídě jsme při uplatňování a kombinování různých projevů a typů donucovací moci v parciálních interakcích se žáky tedy mohli identifikovat výše zmíněné miniscénáře, které chápeme jako určitý více či méně stabilizovaný způsob zvládání situací ve tř́iě. Výše jsme představili tabulku základních typů donucovací moci, jež se vztahují hlavně k vyvolávání žákůa, ale lze ji rozširíit také o aspekt řízení třídy, u něhož se navíc projevuje kritérium represivity. $\mathrm{V}$ případě, kdy učitel donucovací mocí reaguje na již vzniklý kázeňský prohřešek, jedná se o donucovací moc represivní. V př́padech, kdy využívá donucovací moc, aby předcházel vzniku kázeňských problémů, jedná se o donucovací moc preventivní. Obdobně o využívání kázeňských technik hovoří např. Šedová (2012, s. 236), která zmiňuje preventivní, monitorovací a signalizační, a také intervenční (tedy často represivní) aktivity učitele. Preventivními aktivitami se snaží učitelé předcházet nekázni ve třídě, kdežto intervence mủže mít podobu sankce. Kritérium preventivního či represivního užití donucovací moci rozšiřuje typologii donucovací moci na 8 typů (tabulka 7). 
Tabulka 7

Rozšriřená typologie donucovací moci

\begin{tabular}{|c|c|c|}
\hline & Verbální & Neverbální \\
\hline \multirow[t]{2}{*}{ Přímá } & Preventivní & Preventivní \\
\hline & $\begin{array}{l}\text { Represivní } \\
\text { Př́klad: Potrestání žáka (napríklad vyvolání, } \\
\text { výhrǔza) }\end{array}$ & $\begin{array}{l}\text { Represivní } \\
\text { Př́klad: Ignorace žáka }\end{array}$ \\
\hline \multirow[t]{2}{*}{ Nepřímá } & $\begin{array}{l}\text { Preventivní } \\
\text { Přílad: Donucování látkou nebo interakcí se } \\
\text { tř́dou }\end{array}$ & $\begin{array}{l}\text { Preventivní } \\
\text { Příklad: Aktivizace žáků }\end{array}$ \\
\hline & $\begin{array}{l}\text { Represivní } \\
\text { Příklad: Neadresné kárání třídy }\end{array}$ & $\begin{array}{l}\text { Represivní } \\
\text { Příklad: Paralingvistické projevy } \\
\text { směrem ke tř́dě }\end{array}$ \\
\hline
\end{tabular}

V následně představených miniscénárích se mimo jiné projevuje fakt, že ani samotné vyvolávání žáků opravdu není tak „jednoduchým“ projevem donucovací moci, jak by se mohlo zdánlivě jevit. To je patrné zvláště v situacích, v nichž dochází k tzv. kř́žení diskursů - učitel vyvolává žáka nikoliv proto, aby rozvíjel/zjištoval znalosti (didaktický diskurs), ale proto, aby řídil třídu (regulativní diskurs). Vyvolávání, na první pohled didaktická strategie k naplňování obsahu, tedy ve skutečnosti může zároveň být strategií řízení třídy i způsobem trestánín ${ }^{30}$. Např́klad studentka Karla odpovídá na otázku, dle jakých kritérií vyvolává žáky k tabuli: „Kluky, holky, podle toho, kterej zrovna zlobí nebo koho potřebuji vytáhnout před tabuli." (Karla). Křrižení diskursů jako takové se netýká pouze vyvolávání, ale má při využívání donucovací moci studenty učitelství řadu podob. $\mathrm{K}$ těm se dostaneme $\mathrm{v}$ níže zmíněných příkladech miniscénářủ, jež kombinují různé typy donucovací moci, takže jeden miniscénář může mít např́klad preventivní i represivní podobu, př́mou i nepřímou podobu apod.

\section{Miniscénář „Adresná výstraha“}

Adresná výstraha je miniscénářem přímé donucovací moci, tedy moci zaměřené na konkrétního žáka. Tento miniscénáŕ pracuje s různými podobami kontroly, jejímž vykonavatelem je student učitelství na praxi, který do jisté míry disponuje jak prostředky formální kontroly (známka, poznámka), tak i neformální kontroly (verbální výtka, neverbální výtka). V širším smyslu je zde student učitelství agentem sociální kontroly, tedy tím, kdo dohlíží na dodržování očekávaných norem ve třídě a jejich porušení trestá. Adresná výstraha může probíhat verbálně nebo neverbálně a může být nejen represivní, ale také preventivní. Příklad neverbální preventivní adresné výstrahy v hodině studentky Věry je součástí následující ukázky.

30 A jak jsme již zmínili, tak občas i způsobem odměňování žáků (srov. kapitola 4.4). 


\section{Ukázka 28}

Studentka učitelství Vèra v hodině českého jazyka v osmém ročníku probírá sponová slovesa.

U: ((přikývne)) Být, bývat, stát se, stávat se. Super. ((úsmèv, přesouvá se ke svým poznámkám na stole)) Tak jsme si to trošku zopakovali. (1) Ještě to jméno jak je, jaké tam doplňujeme to jméno, ((bere ze stolu do rukou papíry)) když je to jmenné se sponou ((s úsmèvem ukazuje pomocí papirů na jednu ze čtyř hlásících se žákyñ))

D: Př́idavné a podstatné jméno.

U: Př́davné a podstatné. (1) No takže to jsme si trošku projeli (.) doufám, že i těm, kterým to nebylo úplně jasné ((divá se na Alberta)) si (.) to trošku srovnali (.) a tedkka podle toho bude vypadat ten test. (1) Já vám to tady rozdám. ((rozdává testy))

Donucovací moc je zde zacílena na konkrétního žáka a manifestuje se neverbálně (pohledem). Jedná se o krátkou sekvenci, ve které studentka dává žákovi Albertovi najevo, že si je vědoma jeho potenciálního deficitu v probíraném učivu. Donucovací moc je užita preventivně, žák zatím neměl př́ležitost podat výkon v testu, jenž se studentka teprve chystá rozdat. Žák může vnímat donucování $\mathrm{k}$ výkonu $\mathrm{v}$ testu skrze neverbální tlak studentky. Tento miniscénář může vést žáka ke snaze o větší výkon, nebở $\mathrm{v}$ prípadě neúspěchu by mohl následovat trest (např́íklad špatná známka nebo výtka učitelky), který učitelka tímto miniscénářem Albertovi avizovala.

Běžněji však studenti užívají Adresnou výstrahu represivně, to znamená ve chvíli, kdy žáci porušují pravidla třídy či nespolupracují. Kromě často zmiňovaného dlouhého významného pohledu využívají studenti jako neverbální výstrahu také tleskání (Karla: „No a eventuelně ještě když už je to teda moc, tak jsem myslím zatleskala párkrát“), ticho (Milena: „Dneska jsem čekala asi dvě minuty, než jsem začala diktovat diktát prostěc) či proxemiku (Věra: „Nebo tak můžu k němu třeba přijít").

$\mathrm{V}$ relativně vyhrocenějších situacích studenti učitelství mohou přecházet od neverbálního donucování k donucování verbálnímu. Verbální podobu Adresné výstrahy $\mathrm{v}$ represivním modu najdeme $\mathrm{v}$ hodině vyučované studentkou Alicí.

\section{Ukázka 29}

Alice v hodině občanské výchovy řeši s žáky otázku, zda by se zúčastnili oslavy narozenin svého dědy nebo oslavy s kamarády.

D Klára: Tak já bych taky zůstala, protože děda má narozeniny a narozeniny nemá dvakrát do roka, jsou jednou a kamarády ty si užiju na druhej den.

U: Ehm. Výborně. (.) Vzadu? 
K: (nnn)

U: Takže bys dokonce vzal kamarády a přivedl je na dědovu oslavu?

ŽZ̆: ((šum))

U: Ale holky tiše, neslyším. (,) Tak dál.

D: Já? Tak já bych si nic nedomlouvala jako jinýho. Když bych jako věděla, že děda má narozeniny.

U: Ehm. Děkuju. Posloucháme se?

ŽZ̆: ((šum))

U: ((jde smèrem $k$ žákům v lavicích u okna)) Tak kluci.

K: (nnn)

ŽZ̆: ((̌̌um))

U: Ostatní se utišíme prosím vás. Ještě jednou.

K: Že bych si ty kamarády vzal k dědovi.

U: Vzal by si kamarády $k$ dědovi. Dobře.

(nnn)

U: Holky tady. Tak holky ještě jednou, jestli se budete bavit tak vás posadím sem. Je to jasný? (.) Tak. Jak byste reagovali vy?

CU: ((jde k bavícím se žákưm)) Ztište se. Ticho. ((šeptá a výhružně gestikuluje))

U: ((mluví s žákyněmi u okna))

U: Dobře. Super. Děkuju moc. A my se ted’ posuneme trochu dál.

Adresná výstraha aplikovaná opakovaně studentkou ve třídě v tomto př́padě nefunguje. Žáci se neustále baví, což je způsobeno mimo jiné tím, že nevnímají donucovací moc studentky jako dostatečně silnou. Studentka nedisponuje tresty, které by žáci vnímali jako relevantní (pravděpodobně i proto, že nevnímají dostatečnou legitimitu studentky v roli učitele - srov. kapitola 4.2). Studentka přechází $\mathrm{k}$ výstraze přesazením, jež však později nerealizuje. Váhu výstraze dodává až intervence cvičné učitelky, která situaci ve třídě na určitou dobu zklidní. Z ukázky je patrné, že studentka nedisponuje relevantními prostředky donucovací moci, tedy takovými, které by byly pro žáky významné. V miniscénáři Adresná výstraha se kříží oba diskursy při práci učitele se školní třídou. Na první pohled slouží Adresná výstraha k řízení třídy, tedy jako projev diskursu regulativního, ovšem zároveň je důležitým prostředkem naplňování didaktických cílů, nebở bez zvládnutí třídy nelze didaktické cíle naplňovat. Je-li Adresná výstraha pro žáky relevantní, pak vede $\mathrm{k}$ jejich konformitě s požadavky studenta učitelství.

Adresné výstrahy mohou být studenty na praxích využity i zneužity. K takovému zneužití by docházelo např́iklad, kdyby prostřednictvím nich učitel žáky před tř́dou ztrapňoval. To zjištovala položka dotazníku Když mi to v hodině nejde tak, jak si tahle učitelka predstavuje, před celou třídou mě ztrapní. Důležitým zjištěním při vyhodnocení této položky je, že studenti nevyužívají donucovací moc 
k vyvolání negativních emocí u žáků. Hodnota této položky u studentů ve vzorku se pohybovala od $\bar{x}=1,11$ do $\bar{x}=1,92$ (kde maximum je 5).

\section{Miniscénář „Za jedna nebo za pět“}

Jedním z mála způsobů, jenž vede žáky k podřízení se pokynům studentů učitelství, je zkoušení a známkování. Zkoušení a známkování představuje způsob kontroly ve školní třídě, který je odrazem komplementárního vztahu mezi studentem učitelství na praxi (učitelem) a žáky. Student může uplatnit svoji donucovací moc tehdy, pokud žáci vědí, že bude následovat kontrola úkolu, jež je poté spojena s odměnou nebo trestem. Kontrolu proto studenti hojně využívají a žákům připomínají, že jejich práce jimi bude přezkoumána. Studentka Milena např́ílad v hodině občanské výchovy avizuje kontrolu takto: „A nezapomeňte se hlavně pořádně podívat na to, co jsme dneska společně probrali. Ještě jednou si doma přečtěte ten zápis. Protože zítra budu kontrolovat, jak jste dávali v dnešní hodině pozor a co jste se naučili. Takže na to hlavně nezapomeňte se na to pořádně ještě doma podívat.“

Studentka Milena pracuje s kontrolou jako mechanismem donucování výrazně. Žáci ji v dotazníkové položce Když téhle učitelce nedonesu úkol, cítím se fakt špatně připsali hodnotu $\bar{x}=3,81$, která je oproti ostatním studentům mnohem vyšší. Nejnižší hodnotu v této položce získala studentka Alice $(\bar{x}=1,67)$, která má však zároveň nejvyšší hodnotu legitimní/donucovací moci ze všech studentů $(\bar{x}=2,99)$. U těchto studentek se tedy liší způsob využití kontroly jako prostředku donucovací moci. Alice spíše uživá tvrdé donucování, odvozené z potřeb učitele ${ }^{31}$, zatímco u Mileny je donucování měkké, vycházející z potřeb žáků. $V$ tomto prrípadě je u Mileniných žáků potřebou vyhnout se prožívání negativních emocí spojených s nesplněním úkolu.

Kontrola znamená pro žáky jeden z prostředků, které je vedou k podřízení se donucovací moci studenta učitelství a ke konformitě s institucí školy. V rozhovoru zmiňuje Radek známkování jako efektivní prostředek k naplnění požadavků učitele:

\section{Ukázka 30}

Radek: Kdybych jim řekl, že to bude na známky, tak si to nedovolí.

Tazatel: Mhm.

Radek: Ale oni věděli, že to nebude na známky, takže si to mohli dovolit.

Tazatel: Mhm. Proč si myslíte, že právě ta známka by je zbrzdila?

Radek: No tak ono jako, kdyby dostali pětku, tak asi by už z toho radost neměli, takže by se snažili. A on ten diktát je dost těžký, že jo. Takže si myslím, že by bylo škoda dostat špatnou známku.

31 Př́íkladem tvrdého donucování jsou položky Když v hodině nedělám to, co tato učitelka chce, naštvaně na mě kouká (studentka Alice získala hodnotu $\bar{x}=3,83$, studentka Milena $\bar{x}=2,21$ ), I když kritizuji pravidla, tahle učitelka si stejně udělá, co chce (studentka Alice získala hodnotu $\bar{x}=3,25$, studentka Milena $\bar{x}=2,07$ ). 
Význam známek pro žáky je pak viditelný v záznamech z vyučovacích hodin. Známka je pro ně důležitá, ovšem pouze tehdy, má-li reálnou váhu, to znamená, může-li student učitelství udělit žákům známky, které se skutečně počítají (srov. kapitoly 4.2 a 4.4). To, že je toto kritérium pro žáky významné, dokládají jejich dotazy, zda je cvičení na známky a zda se známka počítá i v hodinách cvičné učitelky. Známkování je tak prostředkem donucovací i odměňovací moci, který žáci dle studentů akceptují, a tím pádem naplňuje studentovu donucovací moc.

\section{Ukázka 31}

Studentka učitelství Karla v hodině dějepisu avizuje způsob, kterým bude probihat opakování učiva $z$ minulé hodiny.

U: Já mám pro vás takové trošku malé překvapení.

((asi polovina žáků sleduje studentku))

U: Já budu klást otázky, vy budete správně odpovídat, předpokládám (učebnice zavřeme). Za správnou odpověd’ ode mě dostanete lísteček a za tři lístečky malou jedničku.

K: Kolik těch otázek bude? (.) Dvě?

K2: [Pan'čelko] (.) Pančelko...((hlásí se))

U: Roman by chtěl něco říct...

K Roman (?):Pančelko, jen malou jedničku nebo velkou?

U: Paní učitelka si určí, jestli to bude moc malá nebo velká jednička.

K Roman: Ale bude to do žákovské?

K: [(hodně velká)]

U: Bude to do žákovské.

K Roman: Tak to jo, tak to jo.

Žák Roman přistupuje na způsob práce, protože je mu přislíbeno, že známky z opakování budou legitimní (tzn. zapsané v žákovské knížce). Studentce Karle se pak daři opakování realizovat dle způsobu, jejž naplánovala (srov. kap. 4.4.1.2, s. 118). Kontrola $\mathrm{v}$ tomto miniscénáři nemusí mít jen podobu známky. Jiný mechanismus kontroly zmiňuje Milena: „Když je to nějaký pracovní list, tak si to musí vlepit. Ti mladší musí mávat sešitem, že to maj nalepený. " Předem avizovaný zpo̊sob kontroly je prostředkem donucovací moci, nebot může být následován trestem v různé podobě. Celkově význam kontroly zachytil ve svém deníku Radek: „Dnešní den jsem zjistil, že žákům, které neznáme, nemůžeme plně důvěřovat. Pokud žáci nemusí úkol zpracovat písemně, úkol neudělají. Dále jsem zjistil, že učitel musí dost času věnovat nejen prípravě hodin, ale i kontrolám testů, diktátů apod.“

Známkování představuje mechanismus „materializované“ kontroly, na rozdíl od kontroly v miniscénáři Adresné výstrahy, která může mít často relativně skrytou podobu (verbální nebo neverbální). Miniscénáře donucovací moci však nemusí operovat jen s prvky kontroly. 


\section{Miniscénář „Nevidím Tě, neslyším Tě“}

Miniscénář Nevidím Tě, neslyším Tě je typický tím, že student učitelství žáka ignoruje. Může se tedy zdánlivě jevit jako situace rezignace na donucovací moc. Jedná se však spíše o transformaci donucovací moci učitele. V tomto miniscénáři jde o donucovací moc neverbální, kterou student učitelství užívá preventivně i represivně. Donucovací moc se zde projevuje skrze rozehrání předem naplánované struktury vyučovací hodiny studentem učitelství bez ohledu na neočekávané vstupy žáka, jež do jisté míry vnímá jako rušivý element. Následující ukázka z hodiny českého jazyka u studentky Petry ilustruje situaci, kdy si žáci z diktátu dělají legraci (žákyně Adriana) nebo jej komentují jako zbytečnost (žák Vojta). Ignorace rušivých vstupů žáků studentovi slouží k udržení naplánované struktury hodiny ${ }^{32}$. Žáci tak mohou částečně reflektovat tento projev donucovací moci studenta, který spočívá v nevybočení $\mathrm{z}$ předem naplánované struktury, již se žáci snaží narušit. Přistoupí-li žáci na tento miniscénář v režii učitele, pak se podřizují jeho představě vyučovací hodiny, takže většinou přestanou vyrušovat, protože jsou ignorováni. Trestem pro žáky byla ignorace učitele, která dovedla žáky ke spolupráci.

\section{Ukázka 32}

Diktát v šesté hodině českého jazyka studentky učitelství Petry, sedmý ročník

U: Tak, diktuju, pište si. Hladoví psi.

D Adriana: Hladoví co?

U: Hladoví psi.

ŽZ̆: ((píšou si))

U: Hladoví psi.

D Adriana: Takže hladový Adam.

K: Máme to napsat s čárkama?

U: No, s čárkama.

K Vojta: (nnn)

U: No, přesně tak. Drahokamy.

K Vojta: Jo, to bude zas to.

U: No, všecko dokola.

K Vojta: Jak u blbých.

((dále žáci píši diktát))

Miniscénář Nevidím Tě, neslyším Tě se může v jedné vyučovací hodině periodicky opakovat. Ignorace tak není ukončená, ale vrací se ve vztahu k jednomu

32 Studenti na praxi si většinou hodiny plánují velice pečlivě, ovšem občas bez ohledu na reálnou možnost tento plán dodržet. Často se pak potýkají s „nestíháním“: „Nestíhám za třičtvrtě hodiny, když je takhle jako nabitej program“ (Lenka), „To byla ta Velká francouzská revoluce. Měla připraveno kř́ižovku s tím, že ji budeme postupně doplňovat, jak budu tu francouzskou revoluci učit, ale ((smích)) ta byla na ně těžká, takže si s ní vůbec nevěděli rady, takže to myslím jsme to ani nedokončili ((smích))... Kolikrát jsem také zjistila, už zvoní? Ani jsem se za tu hodinu nestihla podívat na hodinky a už zvoní" (Karla). 
žákovi nebo ve vztahu k různým žákům ve třídě. Ignorace rušivého chování se dá považovat za vhodnou strategii ve vztahu k drobným kázeňským prohřeškům ve tř́dě. Pokud se ale porušování pravidel začne stupňovat, třída se stává stále obtížněji zvladatelnou a učitel může $\mathrm{v}$ určité chvíli řešit tuto situaci nevhodně výbuchem vzteku či kolektivním trestem pro třídu (srov. Cangelosi, 2006).

Miniscénář Nevidím Tě, neslyším Tě může být i strategií doporučenou cvičným učitelem. Takové doporučení dostala studentka Zdena, která podle výpovědi v rozhovoru doporučení přijala, přestože s ním nebyla zcela ztotožněná.

\section{Ukázka 33}

Zdena: Já jsem se rozčilovala první hodinu skoro celou. A pak mně učitelka říká, že si ho absolutně nemám všímat, že on to prostě dělá a že s děckama domluvili, že si jeho chování nebudou všímat, protože když si ho budou všímat, tak je to ještě horší. Dobře, no a jakej má prospěch? A vona ř́kala, všechny domácí úkoly nosí, všechny pomůcky nosí. Nepropadá, nic. Takže já jsem jakoby nechápala, že v hodině se chová jako hulvát a jako prospívá dost dobře.

Tazatel: Ahm.

Zdena: Jo. (.) Tak vlastně mně bylo doporučený, abych si ho nevšímala, protože když si ho budu všímat, čím víc si ho budu všímat, tím to bude horší.

Tazatel: Pomohlo to teda?

Zdena: Jo, bylo, ta situace byla lepší. Ale jako. Haha.

Tazatel: Měla jste z toho dobrý pocit nebo neměla?

Zdena: Jako jo, ale prostě přesto pořád jakoby nespolupracoval, no. Ale když prostě mě bylo řečeno, že ho mám ignorovat, tak jsem ho ignorovala, no.

V uvedené ukázce se jednalo o rušivé chování, které je v rozporu s didaktickými cíli studenta učitelství. Vstupy žáků $\mathrm{v}$ tomto miniscénáři však nemusejí být jen $\mathrm{v}$ rozporu s didaktickými cíli. Zatímco $\mathrm{v}$ předchozí ukázce užívala studentka donucování zejména $\mathrm{k}$ tomu, aby žáci neodbíhali od probírané látky, $\mathrm{v}$ další ukázce je tomu naopak. Studentka ignoruje vstupy žáků, které se k učivu vztahují. Donucovací moc je opět využita $\mathrm{k}$ udržení předem naplánované struktury vyučovací hodiny, avšak bez zohlednění možného naplnění didaktických cílů skrze zodpovězení otázek žáků. Ilustruje to jedna $\mathrm{z}$ vyučovacích hodin, v níž se studentka Petra zabývá určováním mluvnických kategorií u sloves.

\section{Ukázka 34}

Studentka Petra se v šesté hodině v sedmém ročníku zabývá určováním mluvnických kategorii u sloves.

U: Kdo to neměl, si to doplní. Takže znova, opakování. Jaké se určují mluvnické kategorie u sloves? (2) Honzo? Jaké se určují mluvnické kategorie u sloves? 
Adriano!

K Honza: Můžu?

U: No.

K Honza: No tak osoba, číslo, čas, způsob, rod, třída, vid a-

U: Třída se neurčuje jako mluvnická kategorie u sloves.

K: Tř́́da?

U: To není mluvnická kategorie.

K Marek: Jak to, že ne?

U: Tak to urči, Adriano.

D Adriana: Ano?

U: Urči to.

Žák Honza uvádí mezi mluvnickými kategoriemi u sloves také tř́ídu, což studentka označuje za chybnou odpověd. Žák Marek se podivuje tomu, proč se třída u sloves neurčuje, studentka však nechává jeho iniciativu zcela bez odezvy (jde také vlastně o situaci rezignace na IRF strukturu). Zodpovězení otázky by přitom mohlo napomoci pochopení učiva. Žáci v tomto př́padě kladou učiteli otázky, protože nerozumějí probíranému učivu nebo zadávaným instrukcím. Pokud student dostatečně srozumitelně neodpovídá na otázky žáků, může výuka získat podobu jakéhosi „tipování“ odpovědí. Obdobné náhodné tipování a studentčina tendence k ignorování nepochopení úkolu žáky je patrná i v další ukázce.

Ukázka 35

Studentka Petra probírá se žáky ve čtvrté vyučovací hodině v rámci výzkumu slovesný vid.

K: Dokonalý.

U: Dokonavý, ne dokonalý.

ŽŽ: Dokonavý, D.

U: Dokonavý. Tak rríct a doříct. Jak to teda bude?

D Peta: Ríct je dokonavý.

K Marek: Doříct je nedokonavý.

U: Ríct je dokonavý.

K Marek: Doříct.

U: Oboje. Tak a například číst a dočíst.

D Peta: ((hlásí se))

U: Peto.

D Peta: Dokonavý.

$\mathrm{U}$ : Ale co? Oboje?

D Peta: Číst. A dočíst je nedokonavý.

K Marek: Číst je nedokonavý.

U: ((píše na tabuli)) Třeba zaplatit a platit. 
K Marek: Platit je nedokonavý.

K Filip: Platit je dokonavý.

U: A zaplatit?

ŽŽ: To je dokonavý.

K Honza: Dokonalý.

U: Dokonavý. Ne dokonalý. Máš to napsaný, tady je V.

K Honza: A jo. ((smèje se))

U: Je to dokonavý, nedokonavý. Ne L, nedokonalý. ((píše na tabuli))

Ignorace jako neverbální donucovací strategie nese výhodu zejména v tom, že student učitelství nemusí přerušit výklad a namísto probírání učiva se věnovat ukázňování žáků. Výrazná nekázeň však může probírání učiva zabránit. Vztahuje-li se vstup žáka věcně k probíranému učivu, pak se miniscénář ignorace může stát promarněnou didaktickou šancí a může vyučovací hodinu významně narušit. Ignorace žáků jako strategie donucovací moci není u studentů ve zkoumaném vzorku častým jevem. Hodnota položky dotazníku Tahle učitelka mě za trest přehliží, pokud nepracuji tak, jak chce se pohybuje od 1,47 do 2,05. Hodnotu $\overline{\mathrm{x}}=2,05 \mathrm{u}$ této položky připsali žáci studentce Petře, která miniscénář Nevidím Tě, neslyším Tě užívala často ve vztahu k otázkám žákủ k učivu. Žáci mohou být $\mathrm{k}$ ignoraci více citliví, pokud se týká jejich nezodpovězených otázek k učivu, než když je užita jako kázeňská strategie řízení třídy.

\section{Miniscénář „Ulovím vás na didaktickou udičku“}

Zatímco předchozí miniscénáře pracovaly s prvky regulativního diskursu s kontrolou a ignorací žáků, tento miniscénář je založen na učivu, kdy studenti donucují žáky ke spolupráci prostřednictvím probírané látky, kterou považují za zajímavou či významnou. Užití tohoto miniscénáře je typicky preventivní, studenti se jím snaží předcházet nezájmu a nespolupráci žáků, jak to jedna ze studentek učitelství sama pojmenovává v rozhovoru:

\section{Ukázka 36}

Tazatel: Co naopak děláte, když se žáci tvárí znuděně?

Karla: Já nevím, jestli jsem to vůbec zaregistrovala. Většinou tím, že jsem hrnula tu látku před sebe, tak neměli moc jako čas tvářit se znuděně, když opisovali zápis. A zrovna to byla látka, která je relativně bavila, protože co se třeba zrovna týče císařovny Sissi a potom královny Alžběty, tak to bylo takové. No pikantnosti. Žáky na to vždycky uvaří jako na dlouhé nudli. Mamka, když probírá dějiny, tak taky vykládá, komu se děcko otrávilo, protože vypilo džbán mléka, do kterého spadly sirky. Kterýmu skladateli umřela manželka, potom si našel mladší.

Je zajímavé podívat se, jak se tato výuka studentky Karly skutečně odehrála. 


\section{Ukázka 37}

Studentka Karla vyučuje druhou hodinu dějepisu v osmém ročníku.

U: Rudolf byl korunní princ, ale byl úplně jiný než císař, smýšlel více demokraticky, liberálně. Sám se necítil zodpovědný za současnou vládu a tak našel řešení v sebevraždě.

K: A čím spáchal sebevraždu?

U: Zastřelil se. Což byl taky problém, že Habsburkové byli výrazně katolická rodina, takže on nemohl být pohřben na posvěcené půdě. Takže první prohlášení rodičů bylo, že měl srdeční př́ihodu. Ale doktor to nepotvrdil. A novináři se toho chytli a nakonec to vypátrali. Byla to tragédie, vlastně taky tím skončila mužská pokrevní linie. On přesto, že byl ženatý tak vystřídal mnoho žen a tu sebevraždu spáchal se 17ti letou Marí. Takže to mělo takový novinářský pořádný titulek. Ted’ teda ještě jednu ukázku...

Žák se v ukázce na onu didaktickou udičku skutečně chytil, což se projevuje položením otázky na způsob sebevraždy. Situaci lze interpretovat tak, že donucování látkou bylo efektivní, protože pokud by se žák nezeptal, nezískal by odpověd' na to, co ho zajímá (i takovou situaci lze chápat jako určitý způsob trestu ${ }^{33}$ ). Užívání expertnosti jako jisté formy donucování je u našich studentů relativně běžné. Na rozdíl od položek donucovací moci uvedených výše se v položce Tato učitelka říká různé novinky, které souvisís vyučovacím předmětem pohybovaly výsledky našich studentů od 3,08 do 4,67 (průměr na škále od 1 po 5 - souhlasím).

Didaktická udička může být využita nejen preventivně, ale i represivně. V hodinách občanské výchovy reagovala studentka Alice na zvýšenou nekázeň žáků zdůrazňováním praktičnosti probíraného učiva:

Ukázka 38

Studentka Alice vyučuje čtvrtou hodinu občanské výchovy.

U: Dobře. Tak dokončujte. Zkusíme dohromady. (.) Takže máte prosadit svůj oprávněný požadavek. V restauraci vám přinesli studené jídlo. (1) Tak jak byste se zachovali? (.) Zkusíme to. Každá lavice mi řekne svůj způsob, jak byste se zachovali. Tak holky.

((učitelka jde k žákyním v první lavici v radě u okna a obrací se na ně))

D: (nnn)

U: Nahlas. At tě slyší ostatní. No tak co bys jim řekla? (4) Není problém se setkat. Tohle jsou příklady z normálního života, s tím by se každý mohl setkat, nebo se můžete setkat. (5) Tak tiše.

D: TICHO.

33 Namísto trestu zde přichází odměna, čímž se naplňuje druhá strana mince donucovací moci - moc odměňovací. 
Žáci mohou vnímat důraz studentky na využitelnost učiva v praxi. Pokud by učivo neovládali, mohlo by jim to způsobit potíže v reálném životě. Jedná se tedy o jakýsi odložený důsledek nepozornosti v hodině. Trest za nepozornost nepřijde př́mo od studentky, ale jako přirozená životní konsekvence.

Miniscénář Ulovím vás na didaktickou udičku však nemá jen cíle didaktické, jak by se na první pohled mohlo zdát. $\mathrm{V}$ př́padě preventivního i represivního užití sleduje tento miniscénář také cíle regulativní. Studentka Karla přesvědčuje žáky o obsahu skrze "pikantni“ fakta nikoliv pouze proto, aby si žáci látku zapamatovali, ale také proto, aby získala žáky na svou stranu (projev regulativního diskursu). Učivo je pro studenty učitelství prostředkem řízení třídy, což pojmenovává Karla v rozhovoru, tím, že „hrnutím látky předchází znuděnosti žákư“.

\subsubsection{Shrnutí: Význam donucovací moci ve třídách začínajících učitelů}

Přestože žáci nemusí vnímat donucovací moc studenta učitelství nijak výrazně, pro samotné studenty na praxi může být tato složka uplatňování moci poměrně důležitou. Záleží však vždy na tom, jakým způsobem ji student učitelství uplatňuje a zda s její pomocí vytváří pozitivní klima třídy. V našem výzkumu popsané nedostatky ve zvládání IRF struktury prostřednictvím gradace donucovací moci a rezignace na donucovací moc představují dva extrémní póly donucovací moci učitele, mezi nimiž se vyskytují podoby donucovací moci, které nevrcholí gradací ani rezignací. Jakožto extrémy patří tyto situace spiše k neúspěšnému využití donucovací moci.

Vybočení z IRF struktury jsme charakterizovali pomocí miniscénářůn, které mohou mít preventivní i represivní podobu. Studenti většinou preferují preventivní miniscénáře donucovací moci před těmi represivními. $V$ důsledku nezvládnutí preventivních př́stupů a někdy i v návaznosti na pobídku cvičného učitele však v některých situacích aplikují miniscénáře represivní. Studentka Milena to reflektuje následujícími slovy: „No tak pak zabralo. No ale... Taky si myslím, že třeba by asi to šlo udělat i nějak trošku lepší třeba cestou, než je napomínat, třeba získat si tu pozornost jejich nějak jinak."

Represivní miniscénáře mohou být v některých př́ípadech efektivní, avšak jak již zaznělo výše, jejich repertoár je omezený. Stavět na nich výuku jen nevhodné nejen $\mathrm{z}$ důvodu limitovaných možností využití nástrojů represe $\mathrm{v}$ rukou učitele, ale zejména ve vztahu ke klimatu třídy, které utvářejí. Pospíšil (2015, v tisku) však zjistil, že i zkušení učitelé aplikují častěji direktivní kázeňské prostředky (tresty) než ty preventivní. Zvláště pro studenty na praxi je využití preventivních kázeňských prostředků a s nimi souvisejících prostředků donucovací moci obtížné, protože jejich smysluplné zavedení vyžaduje dlouhodobější kontakt (spolupráci) se žáky. I přesto plní pro studenty na praxi donucovací moc nezanedbatelnou funkci, protože jim může pomoci sjednat ve třídě rychle pořádek (na rozdíl 
od zdlouhavých vyjednávacích strategií), a může tak být nástrojem jejich vlastní ochrany (Lewis, 2001) i ochrany ostatních žáků ve třídě. S její pomocí tedy mohou studenti učitelství vytvářet prostředí, ve kterém lze naplňovat didaktické cíle. V neposlední řadě se pro studenty učitelství na praxi může stát právě využívání donucovací moci jedním z významných prostředků „přežití“ v nové roli (srov. kapitola 1.2).

Rizikem využívání miniscénářů založených převážně na donucovací moci může být to, že si student navykne tyto způsoby práce se tř́́dou užívat především v jejich nekonstruktivní podobě, aniž by reflektoval jejich důsledky. Proto vnáší popis projevů a miniscénářů donucovací moci, včetně jejich důsledků, důležitý prvek do učitelského vzdělávání. 


\subsection{Odměňovací báze moci aneb Dobrý učitel žáky odměňuje}

Kateřina Vlčková

Studenti učitelství na praxi ve třídách druhého stupně základních škol disponují, vedle již zmíněných bází moci v předchozích kapitolách, také odměňovací mocí, a to tehdy, když jejich odměny žáci vnímají jako odměny, tj. pokud žáci přistupují ke studentům učitelství na praxích jako k někomu, kdo je může odměnit (srov. French \& Raven, 1959) a odměna je pro ně zároveň zajímavá.

Podobně, jako tomu je u legitimní a donucovací moci (kap. 4.2 a 4.3), je i odměňovací moc propůjčována studentu učitelství z velké části cvičným učitelem a je orámovaná pravidly, která on a škola nastavuje. Odměňovací moc je dána z nemalé části přidělenou legitimní mocí studentovi učitelství cvičným učitelem, školou a systémem pedagogických praxí, legislativou atd. Odměňovací báze moci učitele vyplývá z jeho legitimní báze moci (že je učitelem), ale také z referenční báze moci (např. že ho žáci přijímají jako vzor a jeho odměny jsou pro ně relevantní). Ve třídě se odměňovací moc studenta učitelství projevuje ve svých konkrétních formách (podobně jako jiné báze moci) ve vazbě na to, jak pravidla chování žáků nastavil cvičný učitel - učitel, který v dané třídě vyučuje daný předmět. Student učitelství tak např́klad přebírá systém odměňování od cvičného učitele, kupř́kladu kdy a za co uděluje jedničky nebo pochvaly.

Odměna sama může mít podobu primárně nemateriální, psychickou (pochvala) či primárně vztahově-psychickou (pochvala před spolužáky), nebo materiálně-psychickou (body, známky, nějaký předmět, sladkost, atd.). Raven (1992, s. 3) v rámci revize klasifikace bází moci ve svých pozdějších pracích odlišoval dvě formy odměňovací moci, a to osobní a neosobní podle toho, zda má odměna pro žáka osobní význam, nebo se jedná o neosobní formu odměny (např́íklad dobrou známku, která však nemá pro žáka osobní hodnotu).

Potenciál odměňovací moci učitele či studenta učitelství $z$ hlediska vzdělávacích cílů závisí na tom, do jaké míry se žáci snaží získat například některou z výše uvedených forem odměny. V situacích, kdy se učitelé podivují, že jejich odměny nefungují, je možným vysvětlením, že žáci učitelovy odměny za odměny nepovažují. Z hlediska odměňovací moci je tedy třeba, aby učitel a student učitelství věděli, co žáky motivuje (např́klad k učení, výkonu...), v jistém smyslu tedy i respektovali např́klad pyramidu potřeb žáků (srov. Maslow, 2014). Výzkumy ukazují (např. Hrabal \& Pavelková, 2010), že se učitelé často neshodují s žáky na tom, co je jejich skutečnou motivací $\mathrm{k}$ učení, $\mathrm{z}$ čehož plyne, že pak učitelé možná motivují žáky méně adekvátně - přislíbí jim odměny, které žáci nevnímají tak silně jako odměny, jak se domnívají učitelé. 
Na odměňovací bázi moci ve školní třídě můžeme nahlížet nejen z perspektivy učitele, ale také žáka, skupiny žáků či třídy (srov. Šedová, 2011). Učitel může využívat své odměňovací moci pro dosahování vzdělávacích a výchovných (ale i jiných) cílů a jejich podporu. Také žáci mohou využívat své odměňovací moci vůči učiteli. Mohou např́klad vyhovět jeho žádosti, když se dlouho nikdo jiný nenabízí, mohou mu pomoci, když je situace ve třídě „na hraně“ atd. Odměňovací moc se projevuje ve školní třídě také mezi žáky navzájem. Podobně jako u moci obecně, i u odměňovací báze moci platí, že uplatňování odměňovací moci je závislé na její percepci protistranou, tj. musí být vnímána jako odměna, tedy učitelem je-li poskytována žáky a mezi žáky navzájem, jedná-li se o odměnu žáka či žáků mezi sebou. Obsahem a formou odměňovací moci žáka či skupiny žáků vůči učiteli i mezi sebou navzájem se však primárně v této kapitole zabývat nebudeme. Zaměřujeme se na odměňovací moc studenta učitelství.

Jednotlivé projevy a formy odměňovací moci učitele se podobně jako jiné mocenské báze projevují $\mathrm{v}$ regulativním diskursu, ${ }^{34} \mathrm{kdy}$ se učitel např. snaží pomocí technik změny chování (srov. Makovská, 2011) přislíbenou odměnou v budoucnosti směřovat chování žáků či žáky odměňuje za dobré chování. Podobně žáci mohou vycházet učiteli vstříc, podpořit ho, když je ve třídě konflikt či zmatek, poskytnout mu, co potřebuje $\mathrm{z}$ hlediska managementu tř́dy. Odměňovací moc se objevuje logicky také v didaktickém diskursu ve třídě, který zahrnuje didaktický aspekt výuky a procesy učení žáků z didaktického hlediska.

Odměňovací moc se může podobně jako donucovací moc (viz kap. 4.3) uplatňovat ve formě prímé (konkrétní pochvala žáka, jednička udělená určitému žákovi) a nepřímé (poděkování celé třídě za dobrou práci ve vyučovací hodině). Mưže nabývat formy verbální (např. ocenění správné odpovědi žáka „výborně“) či neverbální (přikývnutí jako potvrzení správné odpovědi). U donucovací báze moci jsme pracovali s miniscénáři založenými na kombinaci přímé a nepř́mé donucovací moci a verbální a neverbální donucovací moci. Tato perspektiva je u odměňovací moci, kterou lze považovat za „druhou stranu téže mince“, omezeně uplatnitelná. Gradace odměňovací moci se ukazuje spíše ve vazbě na obtížnost, detailnost, specifičnost odpovědi na otázku učitele, př́ípadně ve vazbě na to, že již nějaký žák nebyl schopný odpovědět.

V této kapitole budeme hovořit o odměňovací moci studentů učitelství v izolované podobě tak, jak bylo zaměřeno tematické a otevřené kódování ve vztahu k dílčí výzkumné otázce. Nicméně, jak ukazují mnohé dosavadní výzkumy (napřr. Elias \& Mace, 2005; Schrodt, Witt, \& Turman, 2007) a jak bylo již zmíněno v kapitole 3 o metodologii, kapitole $4.1 \mathrm{~s}$ kvantitativními výsledky a v kapitolách 4.2 a 4.3 o legitimní a donucovací moci, některé báze moci (měřené dotazníkem Teacher Power Use Scale - TPUS autorů Schrodta, Witta a Turmana, 2007) spolu 
korelují. TPUS měří velmi dobře na agregované úrovni tzv. prosociálnín ${ }^{35}$ formy moci, jak je autoři označují, tj. referenční a odměňovací moc.

Na našich českých datech použitých pro výpočet srovnávacích výsledků bází moci studentů učitelství Pedagogické fakulty Masarykovy univerzity realizujících své praxe na druhém stupni základní školy z roku 2014 se ukázalo (Vlčková, Mareš, \& Ježek, 2015), že odměňovací moc koreluje silně s expertní mocí $(r=0,70$, $\mathrm{p}<0,01)$ a referenční mocí $(\mathrm{r}=0,69, \mathrm{p}<0,01)$ a naopak slabě negativně koreluje s legitimní/donucovacíi ${ }^{36}$ mocí $(\mathrm{r}=-0,12, \mathrm{p}<0,01)$. Podobně jako legitimní/ donucovací moc negativně koreluje s referenční mocí $(\mathrm{r}=-0,21, \mathrm{p}<0,01)$ a expertní mocí $(\mathrm{r}=-0,43, \mathrm{p}<0,01)$.

Shodné výsledky se ukazují na našich českých datech o učitelích z druhého stupně základních škol (Vlčková, Mareš, Ježek, \& Šalamounová, 2016, v př́ípravě) získaných pomocí adaptovaného dotazníku TPUS (česká adaptace pod názvem Báze moci: verze pro učitele). Kde odměňovací moc relativně silně koreluje s expertní mocí $(\mathrm{r}=0,70, \mathrm{p}<0,01)$ a referenční mocí $(\mathrm{r}=0,65, \mathrm{p}<0,01)$, naopak negativně a slabě koreluje s legitimní/donucovací mocí $(\mathrm{r}=-0,32, \mathrm{p}<0,01)$.

Tyto výsledky ukazují, že žákovská percepce uplatňování odměňovací moci učitele či studenta učitelství na praxi je propojená s percepcí expertní a referenční moci žáky a není rozdílu mezi tím, zda se jedná o zkušeného učitele či začínajícího studenta učitelství. Studenti učitelství a učitelé, které žáci vnímají jako experty a chtějí být jako oni, odměňují žáky více než studenti učitelství a učitelé, které žáci vnímají jako experty méně nebo méně chtějí být jako oni. Vzhledem $\mathrm{k}$ tomu, že se jedná o korelace, však může vztah platit i opačným směrem: čím více studenti učitelství a učitelé žáky odměňují, tím více jsou vnímáni jako experti, a tím více se s nimi žáci ztotožňují.

K podobným zjištěním týkajícím se vztahu odměňovací a referenční moci dospěl např. i výzkum Paynové (2015), v němž některé formy odměn (např̀ u mladších žáků razítka) dobře fungovaly ve vztahu k tomu, jak moc měli žáci učitele rádi (nicméně u starších žáků nezvyšovaly jejich učební výkon). Referenční a odměňovací moc se tedy vzájemně posilují. Odměňování v tomto výzkumu mohlo zvyšovat referenční moc učitele, tedy pokud učitel žáky odměňuje, pak ho žáci mají raději. Ovšem vztah těchto bází moci může být založen i opačně, tedy referenční moc mohla zvyšovat moc odměňovací. Pokud mají žáci učitele rádi, pak připisují větší význam jeho odměnám. Je také logické, že učitel s vysokou referenční bází moci bude žáky pravděpodobněji odměňovat raději (je žákům blí̌ze) a více (protože jim je blíže, disponuje odměnou, např. pochvalou, kterou žáci jako odměnu vnímají) než učitel, u něhož žáci reflektují nízkou referenční

35 Jak bylo zmíněno v metodologické kapitole (kap. 3), s konceptem prosociálních a antisociálních forem moci (referenční a odměňovací versus legitimní a donucovací) v naší knize nepracujeme. Jednotlivé báze moci považujeme za principiálně neutrální, přičemž každý projev jednotlivých bází moci může nabývat prosociálních či antisociálních podob.

36 Legitimní a donucovací moc tvořily v českých datech jeden faktor (více viz kap. 3 a 4.1 a Vlčková, Mareš, \& Ježek, 2015). 
moc. Podobně učitel s vysokou expertní mocí umí nejspíše dle žáků také adekvátně odměňovat, resp. čím více odměňuje, tím více je žáky vnímán jako expert či opačně řečeno, experti odměňují více než učitelé s nízkou expertní bází moci. Zdá se tedy, že „dobrý učitel“ žáky odměňuje a ví, co žáci vnímají jako odměnu.

\subsubsection{Podoby odměňovací moci studenta učitelství na praxi}

V běžné výuce studentů učitelství se objevují specifické formy odměn a odměňovací moci, které nyní blíže popíšeme. Mnohé další formy uplatňování odměňovací moci se vyskytují spíše na třídnických hodinách, v neformálním prostředí a podobně, než prímo $\mathrm{v}$ zaznamenané výuce vedené výrazně v didaktickém diskursu, tj. směrem k naplňování didaktických cílů. Regulativní diskurs je však rámcem didaktického (srov. kap. 2), proto odměny v didaktickém diskursu jsou zároveň (minimálně implicitní) součástí diskursu regulativního. Oba diskursy jsou ve výuce vždy př́tomné.

Podoby odměňovací moci, jež se vyskytovaly $\mathrm{v}$ našich datech, popisujeme v miniscénářích, které představují sekvenci jednání aktérů ve výuce a postihují specifické vzorce práce učitele se tř́dou (srov. Kahler \& Kasper, 1974; více viz kap. 4.3). V našich datech, především videodatech, jsme identifikovali šest základních forem odměn žákům od studentů učitelství:

1) Potvrzení či ocenění správnosti odpovědi - odměna typu „máš to správně“.

2) Udělení jedničky - odměna typu „dám ti jedničku a tvoje paní učitelka ti ji zapíše“.

3) Zajímavosti za odměnu.

4) Speciální podmínky za odměnu.

5) Poděkování za pomoc či dobrou práci.

6) Pochválení za splnění úkolu a dobrou práci.

Obecně řečeno, první dvě formy odměn ( 1 a 2 ) se vztahují k hodnocení žáka a zpětné vazbě, druhé dvě ( 3 a 4 ) k udělení výhod a poslední dvě formy ( 5 a 6 ) se týkají uzavření nějaké činnosti ve výuce. Nejfrekventovanější formou odměňovací moci v našich datech je potvrzení či ocenění správnosti odpovědi žáka na učitelovu otázku, na které se váží studenty učitelství formulované sebenaplňující se pozitivní očekávání týkající se zvládnutí úkolu žákem a zvyšování ceny správné odpovědi odpovídajícími formulacemi otázek učitelem. Velmi specifickou, ale neopomenutelnou formou odměny, je učitelův úsměv či smích vyvolaný žákovským vtipem, který se často vyskytuje právě v těch místech miniscénárử, kde by se jinak objevilo potvrzení či ocenění správnosti žákovy odpovědi.

Zajímavé je zacházení studentů učitelství se známkou jedničkou jako odměnou a vyjednávání se žáky o této formě odměny, jíž věnujeme velkou část této kapitoly, jelikož se na tomto prríkladu dá dobře ukázat proces vyjednávání 
odměňovací moci. Na př́kladu udělování jedniček také popisujeme propůjčování odměňovací moci cvičným učitelem studentovi učitelství na praxi, stejně tak jako paralelní vyjednávání žáků s cvičným učitelem a studentem učitelství.

Poté následuje představení miniscénářu přislíbení zajímavostí a poskytnutí speciálních podmínek, na něž navazuje miniscénář poděkování za pomoc a dobrou práci a miniscénář pochvaly za splnění úkolu a dobrou práci, jak jednotlivým žákům, tak celé třídě.

Mezi našimi osmi studenty učitelství, jejichž výuku jsme z hlediska odměňovací moci analyzovali pomocí videozáznamů výuky a jejích transkriptů, lze sledovat rozdíly $\mathrm{v}$ uplatňování odměňovací moci, a to $\mathrm{v}$ jejích formách, ale především $\mathrm{v}$ intenzitě používání, hlavně ve formě potvrzování správnosti či pochvaly za správnou odpověd'.

\subsubsection{Odměna typu „máš to správněc}

Jednoznačně nejběžnější a nejčetnější formou odměny je potvrzení správnosti žákovy odpovědi studentem učitelství, které představuje určitou základní formu odměny pro žáka za správnou odpověd. Proto popisem této formy odměny začínáme, je tak častá, že extrémně převyšuje co do počtu jakékoli jiné formy odměňování žáků studenty učitelství ve výuce. Odehrává se běžně v desítkách replik během výuky (pokud se právě např. nepíše celou hodinu písemka) a směřuje k nejvíce žákům.

Potvrzování správnosti odpovědi se děje v nejfrekventovanější struktuře vyučovací hodiny, tzv. IRF struktuře (initiation, reply, feed back; Sinclair \& Coulthard, 1975), a to primárně v didaktickém diskursu (srov. kap. donucovací moc 4.3). Studenti učitelství vedou výuku často jako dialog s žáky, a to nejen při opakování učiva, ale také, když vysvětlují novou látku. Studenti učitelství potvrzují správnost odpovědi (naučeného učebního obsahu) častěji než způsobu chování. Přičemž forma odpovědi žáka $\mathrm{z}$ hlediska diskursu a pravidel výukové komunikace se stává také předmětem učitelových reakcí, tj. didaktický diskurs je orámován opět regulativním diskursem, nebot̉ i odpověd’ je vyjádřením správného chování ve třídě. Učitel jako garant správnosti veřejně potvrzuje správnost informace (odpovědi), př́ípadně za správnou odpověd’ i projevuje uznání.

Potvrzování správnosti žákovy odpovědi typicky nabývá několika základních forem. Jedná se především o verbální souhlas, tj. potvrzení správnosti odpovědi žáka verbálně (ukázka 39).

Ukázka 39

Studentka Petra, výuka českého jazyka, třetí hodina, kontrola diktátu slov na s/z, y/i

U: Tak Samir.

K Samir: Shořet.

U: Shořet? S nebo Z? 


\section{K Marek: Z.}

ŽŽ: S.

U: ((kroutí hlavou)) S. Shořet.

K Samir: To mám shořet.

U: Tak to máš dobře.

V ukázce studentka učitelství Petra říká Samirovi výslovně: „Tak to máš dobře, “ což lze považovat za určitou pochvalu, odměnu za to, že Samir řešil úkol správně. K podobnému účelu použivají studenti učitelství obdobné výrazy, jejich repertoáry se nepatrně liší (ukázka 40).

\section{Ukázka 40}

Potvrzovací repertoár studentů učitelství v IRF struktuře vyučovací hodiny ${ }^{37}$

a) tak je to; ehm, přesně tak; dobře; ehm, dobře; ehm, dobře, určitě může být; určitě (Alice),

b) ano; ehm, dobře; ahm, jo, dobře; to určitě; jo, určitě; ahm, správně; to je správně; ano, správně; správně (Milena),

c) ano; ano, dobře; správně; ano, správně (Zdena),

d) jo; máte pravdu; dobře; přesně tak; tak, přesně (Petra),

e) ano; dobře (Karla),

f) ano; jo; no ano; jo, dobrý, tak jo; tohle je správně; přesně, to je ono; ano, přesně; přesně, přesně (Lenka).

Studenti používají jak formální, resp. spisovné (ano, správně), tak neformální, nespisovné vyjádření (jo, určitě), přičemž z dat se nám jeví, že fungují stejně. Pokud žáci odpovídají výčty variant odpovědí, objevuje se automaticky také potvrzení správnosti reflektující varianty odpovědí: „jo, taky mủže být“, „,ahm, to taky“, „no, taky určitě“, „jojojo určitě“, „taky“, „to taky určitě“, „to určitě“ (Milena). Uvedené varianty pocházejí z jedné vyučovací hodiny, kde žáci uváděli více odpovědí na jednu otázku studentky učitelství. Ukazují tak, že studenti učitelství se v jedné vyučovací hodině nezřídka snaží mírně tyto formulace potvrzující správnost odpovědí žáků variovat, což je dáno pravděpodobně tím, že se jedná o velmi frekventovanou podobu odměňování žáků ve většině vyučovacích hodin.

Velmi frekventovanou formou verbálního souhlasu je pouhé ehm, jež používají všichni ze zkoumaných studentů učitelství, i když v různé frekvenci. Považovat „ehm“ za odměnu žáka je ovšem hraniční, nicméně z kontextu tato forma souhlasu roli odměny plní, byt’ samozřejmě jiné formy odměňování mají pro žáka obvykle větší význam než jen pouhé potvrzení správnosti prostřednictvím „ehm“. 
Potvrzení správnosti odpovědi probíhá někdy také neverbální formou, kdy student učitelství např́iklad pouze přikývne či ukáže na žáka, který správně odpověděl. Neverbální forma je však prakticky vždy kombinována s verbální formou potvrzení správnosti odpovědi (např́klad studentka učitelství Lenka ukázala ve výuce dějepisu při opakování učiva na žáka, který správně odpověděl na těžkou otázku prstem a rríká: „Přesně. Přesně!“). Stejně tak tomu je u donucovací moci (kap. 4.3.2), kde téměř vždy neverbální donucování doprovází donucování verbální. Verbální a neverbální souhlas či ocenění správné odpovědi se často propojují, čímž se posiluje expresivita sdělení a zapojení žáků (viz učitelství jako performativní výkon v závěru publikace).

Obvyklá odměna žákovi za správnou odpověd’ ve formě potvrzení správnosti odpovědi se může také nevyskytnout, resp. student učitelství ji nerealizuje verbálně, ani neverbálně, nicméně je z kontextu jasné, že odpověd’ je správně, jinak by student učitelství zasáhl a chybnou odpověd' opravil. Tuto formu lze označit jako chybějící, implicitní či zamlčenou odměnu (srov. zamlčené hodnocení - Šedová \& Švařiček, 2010, Šed’ová, Švaříček, \& Šalamounová, 2012).

Potvrzení správnosti odpovědi probíhá také zopakováním odpovědi žáka (př. žák na otázku studentky učitelství Mileny v občanské výchově, jaká zná místa v Brně, odpovídá „Špilberk“ a studentka učitelství opakuje zřetelně a nahlas: „Špilberk“). Opakování odpovědi je výhodné z didaktického hlediska, protože je zaručeno, že žáci odpověd zaslechnou, pokud ji neslyšeli nebo jí nevěnovali pozornost, případně že ji zaslechnou dvakrát, což by mohlo vést k lepší fixaci učiva.

Potvrzování správnosti odpovědi probíhá někdy také zopakováním odpovědi a jejím rozvedením, které má opět potenciál didaktický, kdy se žáci dozvídají v kontextu další, upřesňující údaje. Např́klad studentka Lenka se v dějepisu ptala žáků, na jakém území se rozléhají Spojené státy vzniklé v roce 1787 . Žák odpovídá „Jenom na východním pobřeži“ a studentka učitelství odpověd’opakuje a upřesňuje: „Ano, jenom na východním pobřeží, zhruba po řeku Mississippi“.

Potvrzování správnosti žákovy odpovědi probíhá také nepřímo, reformulací či zobecněním jeho výroku. Studentka učitelství Lenka se v dějepise ptá žáků, ze kterých zemí se přistěhovali lidé do nově vzniklých Spojených států. Žáci odpovídají „z Velké Británie“, „Francie“, „Itálie“. Studentka učitelství odpovědi nepř́mo potvrzuje upřesněním: „Neminete se, když řeknete střední a západní Evropu“. Je otázkou, zda nepřímé potvrzení založené na zobecnění či reformulaci žáci vnímají i jako pochvalu za správnou odpověd', nejen potvrzení správnosti odpovědi, ale nejspíše také ano.

Nepřesné odpovědi či odpovědi na něco jiného než se student učitelství ptá, bývají také někdy potvrzeny, tj. student učitelství akceptuje žákovu odpověd', nebo ji dokonce pochválí (ukázka 41). Následuje pak ale jejich poupravení, protože odpověd' je nepresná, anebo upřesnění otázky studenta učitelství. Zde se ukazuje specifická forma výukové komunikace - učitel očekává, že žáci budou odpovídat 
na to, „na co se ptá“ (srov. Šed’ová, 2009), nicméně odměna (potvrzení odpovědi, pokud je také správná), není vždy nutně studentem učitelství odmítnuta.

\section{Ukázka 41}

Studentka Alice, výuka občanské výchovy, druhá hodina, téma: Morální dilemata, diskuse nad př́během o Drsňákovi a Kateřině

U: Koho dále máme v př́běhu? Kluci vzadu ((ukazuje na kluky u okna)), koho dál máme $\mathrm{v}$ př́iběhu?

((tichý šum))

K: Krokodýla.

((někteři žáci se zasmějí, učitelka obrátí oči))

U: Výborně, máme tam krokodýlí řeku, ale to není přesně to, na co se ptám...

K: ((jiný chlapec se ozve)) Drsňák!

U: Takže, kdo dál nám vyskytuje ehm vyskytuje se v př́iběhu?

Potvrzení správnosti odpovědi může probíhat ve formě verbálního ocenění správnosti odpovédi žáka studentem učitelství (ukázka 42). V jistém smyslu jde toto ocenění chápat jako další stupeň potvrzování správnosti odpovědi od pouhého „ehm“ přes „dobře“ po „výborně“ či „skvěle“. Ocenění správnosti odpovědi se objevuje např́iklad při opakování učiva, když si žáci pamatují (obvykle náročnější) části učiva. Když si žáci pamatují něco, co bylo těžší si zapamatovat, studenti učitelství to oceňují více než běžnou správnou odpověd. Ocenění správnosti odpovědi se však nemusí týkat jen zapamatování jako nejnižší úrovně Bloomovy taxonomie kognitivních cílů (Anderson \& Krathwohl, 2001), v našich datech se však ocenění správnosti odpovědi v tomto kontextu objevovalo, asi proto, že studenti často kladou otázky nižší kognitivní náročnosti (srov. Švaříček, 2011).

\section{Ukázka 42}

Studentka Lenka, výuka dějepisu, první hodina, osmý ročník, opakování učiva

U: Takže to bychom měli zopakovanou Itálii. Kdy ještě přesně se (.) se sjednotila úplně s Římem?

K: 1804.

K: 1871.

U: Výborně, 1871. A z Itálie se stala?

K: Monarchie.

U: Monarchie, ale jaká?

K: Konstituční.

U: Konstituční, super. Takže to bysme měli takhle... 
Někdy může být ocenění správnosti odpovědi spíše jen alternativou formulace potvrzení správnosti odpovědi („výborně“, „super“ - studentka učitelství Alice; „výborněc, „velmi dobře“ - studentka Zdena). U některých studentů učitelství (např. studentky učitelství Alice a Zdeny) je tato forma frekventovanější, běžnější než u jiných a lze ji vnímat na úrovni běžného potvrzení správnosti, pouze expresivněji, silněji vyjádřenou. Žáci tyto rozdíly rychle reflektují a vnímají, zda „výborně“, „skvělée apod. je skutečným oceněním správné odpovědi či spíše je synonymem „správná odpověd, dobře“. Ve škole tak do jisté míry dochází k inflaci výrazů jako „výborně“, „skvělé“, kdy se oslabuje jejich význam. Míra inflace superlativních výrazů je různá pro různé studenty učitelství.

Ne každé zaznění „výborně“ $\mathrm{z}$ úst učitele je míněno jako pochvala, ve vzácných př́padech se jedná o ironii (inverzní pochvalu), kterou žáci přirozeně odlišují z kontextu situace a intonace studenta učitelství. Jde o kritiku žákova chování, žákových znalostí, př́ípadně celé třídy. Studentka Alice ve výuce občanské výchovy (druhá hodina, osmý ročník) tak říká žákovi, který vstal a „šoupavou“ chůzí přechází ke dveřím ke koši a zpátky: Tak, výborně, že se projevuješ, ale př́ště můžeš se ... trochu mírnit, jo? Ve stejné hodině nazlobeně říká třídě, která je hlučná a bez ohledu na její pokyn, neukončuje aktivitu ve skupinkách: „Výborně, tak já počkám, až se uklidníte všichni“.

$\mathrm{V}$ přímé vazbě na odměnu typu „máš to správně“ se vyskytují formulace studentů učitelství, které implicitně zahrnují, že odpovědět na otázku je něco mimořádného. Např́klad u studentky Alice taková situace začíná obvykle podmiňovacími tvary „Dokázali byste?“, „Věděl by někdo z vás, co to znamená dilema?“ nebo výrazem „Slyšeli jste někdy, že...?“ Studentka používá obrat „pamatujete si někdo?“, „Vzpomíná si někdo na...?“, „je ještě někdo hotový?“", studentka Zdena používá například „ví někdo?“ nebo „kdo ví, se může hlásit“. Tyto formulace jsou typické právě pro výukovou komunikaci učitele a žáka a obvykle za nimi následuje nějaká forma potvrzení správnosti odpovědi, ne nutně však ve formě superlativů.

Pokud žáci odpověd’ na otázku studenta učitelství nevědí, studenti učitelství je povzbuzují pomocí různých technik změny chování, které se vyskytují v podobě formulací pozitivních očekávání týkajicích se výkonu žáků, jež mohou mít důsledky sebenaplňujících se predpovédí (Rosenthal \& Jacobson, 1968). V jistém slova smyslu lze tyto výroky považovat za specifickou odměnu žákům ze strany učitele, jelikož jimi oceňuje schopnosti a kvality žáků. Např́ílad studentka Milena v občanské výchově, když dívky přemýšlí, co obecně říct $k$ tématu životního prostř̌edí, rríká: „Určitě vás něco napadne“. Podobně studentka Lenka v dějepise povzbuzuje žákyni, která jí říká: „A tady u toho nechápu, co mám udělat“, slovy: „Tak zkus aspoň tu Anglii, to určitě dáš ... anebo kousek Francie, tos tu taky určitě byla." Studentka Lenka také ukazuje na to, že odpovědět na otázku je něco mimořádného, současně však, že věří, že to žáci zvládnou: „Tam je to možná maličko složitější, ale věřím, že to ... taky zvládnete“. 
Výše zmíněné verze potvrzení správnosti žákovy odpovědi a ocenění správné odpovědi probíhají často $\mathrm{v}$ jejich vzájemné kombinaci. Objevuje se tak neverbální přitakání, poté „ehm“ a následně například zopakování žákovy odpovědi. Potvrzení správnosti i verbální ocenění správnosti mohou být směřovaná $\mathrm{k}$ jednomu žákovi či třídě, lze je tedy chápat jako přimé a nepřimé, podobně jako u donucovací moci (kap. 4.3), jež je „druhou stranou téže mince“ s odměňovací mocí. Nicméně v prostředí výuky se jedná zpravidla o veřejnou komunikaci, tudíž přímá potvrzení směřovaná $\mathrm{k}$ žákovi jsou současně nepřímými potvrzeními pro celou třídu, které je tak neprrímo sdělována správná odpověd’ na učitelovu otázku, v jejímž podtextu se skrývá práce na osvojování učiva.

Podobně jak ukazuje Šed’ová (2009), je interakce ve výuce velmi specifická ve srovnání $s$ běžnou interakcí, pozitivní zpětná vazba převládá, což mủže být dáno tím, že učitel vyvolává ty, kdo se hlásí, nebo volí častěji ty, kdo vědí, případně klade často také takové otázky, aby je daný žák mohl zodpovědět. Naše data dokládají, že se to týká i chválení a potvrzování správnosti odpovědi odehrávající se v IRF struktuře vyučovací hodiny. Výše uvedené verbální odměňování žáka za správnou odpověd' či odpověd' vůbec nebo dokonce pochvala za ni, at'v pravém slova smyslu či jen používající slovo „výborně“ ve specifickém kontextu výukové komunikace koresponduje s typologií reakcí učitele na správnou odpověd, jak je známá v odborné literatuře (např. Gavora, 2005). Učitel může žákovu odpověd’ akceptovat, tj. stručně potvrdit správnost odpovědi pomocí „ano“, „hm“, „dobře“ a podobně. Druhou možností je tzv. echo, kdy učitel zároveň s akceptací zopakuje správnou odpověd’ at doslovně nebo parafrázovaně. Třetí typ reakce na správnou odpověd' je elaborace, při níž učitel zároveň s akceptací správnou odpověd’ rozvine o další informace. Elaboraci jsme v naší analýze představili v detailnějších variantách (rozšíření, zobecnění, poupravení chybného). A čtvrtým typem je pochvala, při níž učitel správnou žákovu odpověd vyzdvihne a ocení. V naší práci také zmiňujeme implicitní reakci, kdy „nereakce“ je vlastně porozuměna žáky jako reakce. Za pedagogicky hodnotnější se považují, obecně řečeno bez zohlednění konkrétních podmínek, reakce učitele, které vyzdvihují prínos žáka a jeho myšlenku (Gavora, 2005). Žák tak vnímá, že si učitel jeho názorů cení, a to jej může motivovat k učení apod.

Potvrzení správnosti odpovědi žáka učitelem může být žákem vnímáno jako odměna, ale také nemusí, resp. míra, v jaké žák vnímá toto potvrzení jako odměnu, se mủže lišit, a to ve vazbě na učitelovu referenční a expertní moc percipovanou daným žákem u daného učitele.

\section{Úsměv učitele jako odměna žákovi za vtip}

Specifickou odměnou žákovi, která se vyskytuje ve výuce studentů učitelství (stejně jako ve výuce zkušených učitelů), je odměna za vtip ve formě úsměvu či smíchu studenta učitelství a potažmo samozrejejě také spolužáků, př́ípadně 
zadržovaného či utajovaného smíchu. Úsměv jde jen zřídka ovládnout, když je situace vtipu nečekaná. Situačně se tento typ neformální odměny odehrával v našich datech nejčastěji opět v IRF struktuře vyučovací hodiny. Vyskytoval se na místech, kde bychom mohli očekávat učitelovo potvrzení správnosti odpovědi žáka či pochvalu žákovi za správnou odpověd. Místo potvrzení správnosti či verbalizace chybné odpovědi se třída a učitel pouze zasmějí. Úsměv je odměnou v situacích, že vtip byl obvykle zamýšlený, v jistém smyslu jako provokace učitele (srov. Šedová, 2013), nikoli jen jako chyba či přeřeknutí žáka. Z mocenského hlediska tak žák získává převahu nad učitelem nebo výukovou situací. U studentky Alice v občanské výchově při diskusi morálních dilemat v př́iběhu vzbudí její úsměv slovní hřrička žáků o drsném Drsňákovi. Studentka se ptá: „Co víme o Drsňákovi?“ a žáci odpovídají: „Že je drsný.“ Žáci neodpovídají na otázku studentky učitelství ve výukovém diskursu a zároveň však na ni odpovídají správně $\mathrm{v}$ běžném diskursu, a plní tak zadání úkolu. Tento kontrast mimo jiné aspekty je základem podobných vtipů ze strany žáků (ukázka 43). Žáci tyto vtípky zkoušejí tedy nejen na učitele, ale přirozeně i na studenty učitelství na praxích.

\section{Ukázka 43}

Studentka Lenka, výuka dějepisu, druhá hodina, osmý ročník

U: Chcete vědět, co je na podstavci Sochy svobody?

$\mathrm{K}: \mathrm{Co}$ ?

U: Jaký nápis?

K: Made in China.

$\mathrm{U}: \mathrm{Ne}(($ směje se))).

CU: Odkud je?

$\mathrm{U}: \mathrm{Z}$ Francie.

CU: Děkuju.

V ukázce 43 žák bystře reaguje na otázku studentky učitelství a prokazuje současně znalost, že mnoho produktů je z Číny a že na těchto produktech bývá anglicky napsáno „Made in China“. Cvičná učitelka do situace zasahuje zezadu z učebny a žádá očekávanou odpověd’ (odpovídající rigoróznímu výukovému diskursu). Snaží se tedy srovnat mocenskou situaci ve třídě, která je „nevinně“ na straně žáků (srov. Šedová, 2013). Paradoxně jí odpověd’ poskytuje studentka učitelství, nikoli žáci. Studentka učitelství tím, že na rozdíl od žáků zná odpověd, tak mocenské vztahy srovnává. Cvičná paní učitelka jí děkuje - vlastně za to, že je diskurs výuky zpět ve svém očekávaném výukovém rámci. Současně se zde však může objevovat naznačení toho, že role studentky učitelství vůči cvičné učitelce je studentka. O komplementárních rolích studenta učitelství a cvičného učitele diskutujeme v kapitole 4.2. 


\subsubsection{Odměna typu „dám ti jedničku a tvoje paní učitelka ti ji zapíše“}

Studenti učitelství na praxích také $\mathrm{v}$ omezené míre pracovali s udělováním jedniček za dobré výkony a jejich používáním jako motivačních faktorů ve vybraných, $\mathrm{k}$ tomu určených situacích. Udělování jedničky musí být obvykle schváleno cvičným učitelem studenta učitelství, který danou třídu učí po celý rok, i když někdy student získá obecnou pravomoc známkovat, kdy uzná za vhodné. Udělování jedniček tedy souvisí s připsáním legitimní moci studentu učitelství cvičným učitelem (viz kap. 4.2).

\section{Neúplné propůjčení odměňovací moci studentům učitelství cvičnými učiteli}

Např́iklad studentka učitelství Věra (český jazyk, druhá hodina) zapisovala jednomu žákovi splnění domácího úkolu (přečtení si literárního díla a jeho představení spolužákům) do žákovské knížky. Zde byla tedy odměňovací moc předána cvičnou učitelkou studentce Věře. $V$ jiném př́padě sice Věra jedničku udělila všem, kteří referát měli a měli ho dobře připravený, ale zapsání známky pak měla učinit cvičná učitelka: „Ještě někdo má referát? To bylo všechno? To bylo všechno. Tak referáty byly perfektní. Dostanete za ně jedničku, vy, co jste si je připravili. Paní učitelka vám ji potom zapíše." Odměňovací moc nebyla tedy plně studentce učitelství na praxi cvičným učitelem propůjčena či předána, jelikož známky mohla studentka zapsat sama, a to při dalších návštěvách školy či ve vyučovacích hodinách na průběžné, dlouhodobé praxi. Př́padně lze vnímat nekonsekventnost předání odměňovací moci v kontextu legitimní moci. Udělení jedničky v tomto př́padě sloužilo jako první informace pro žáky o tom, že studentka učitelství má pravomoc je hodnotit a známkovat. Zároveň sloužilo jako odměna za dobrý výkon a současně jako motivační faktor pro ostatní žáky, kteří budou mít referát prríště, k tomu, aby se připravili, případně jako určitý (byt ne zcela jistý) signál o tom, že jejich snaha bude odměněna.

V případě studentky učitelství Lenky a první písemky s ní (ukázka 44) si žáci mohou dojít na konci další hodiny, kde jim předala výsledky, pro jedničku, pokud tak napsali test. Jelikož se jedná o první test s ní a zdá se i jiný typ otázek, než jsou žáci zvyklí s cvičnou paní učitelkou, horší známky se nezapisují.

\section{Ukázka 44}

Studentka Lenka, výuka dějepisu, druhá hodina, osmý ročník, vyhodnocenípisemky

U: Nejdřív, ehm, mrknete se na ty písemky, co jste psali se mnou. Někomu to dopadlo dobře, někoho chválím. U někoho asi možná tu šestou hodinu se vám už nechtělo přemýšlet a taky jsem viděla, že zřejmě nejste schop- nebo nejste schopni, nejste zvyklí na tenhle typ otázek, takže kdo bude známku chtít, na konci hodiny mně to odevzdá, známka mu bude zapsaná. Kdo známku chtít nebude, nemusí ji mít... ((dá žákyni písemky na rozdání)) Takže kdo bude chtít známku zapsat, na konci hodiny mi to odevzdá. 


\section{D: ((rozdává pisemky)) \\ U: Ostatní se můžou zahodit.}

Pokyn k odevzdání testu zpět (pro udělení jedničky) Lenka opakuje na konci hodiny. Po chvíli upozorňuje na to, že si pro ni přišlo mnohem méně žáků, než na ni mělo nárok (ukázka 45). Tato situace může být dána tím, že z jiné aktivity, která probíhala $\mathrm{v}$ téže hodině (jednička třem nejrychlejším $\mathrm{z}$ nové písemky) zapisuje známku cvičná učitelka, jež na dotaz žáků tuto odpovědnost přejímá a garantuje, byt’ to v průběhu hodiny vyznívalo, jakože jedničky bude zapisovat studentka Lenka. Žáci tak nepracují s představou, že by jim jedničky z písemky z minulé hodiny opravdu zapsala studentka učitelství. Zajímavý je nález, že studenti učitelství se někdy přímo snaží, aby žáci jedničky dostali. Ukazují tak, že chtějí žáky odměňovat, považují jedničky za důležité a domnívají se, že percepci důležitosti jedniček sdílí s žáky.

\section{Ukázka 45}

Studentka Lenka, výuka dějepisu, druhá hodina, osmý ročník, vyhodnocenípísemky

U: Ukončíme to. Tak já vám děkuju, přiště budeme pokračovat. Doufám, že (nnn).

CU: Já jsem se nestačila divit.

K: Co ty známky?

CU: Kluci, známky vám zapíšu.

U: A kdo chce známky z toho mýho testu, tak mně vratte písemky.

ŽŽ: ((žáci dávají židle nahoru))

U: Já myslím, že tady bylo mnohem víc jedniček. Vy ty jedničky nechcete?

Zdá se, že situace s připsanou legitimní moci studentů učitelství nemate jen samotné studenty učitelství v tom, že nevědí, co vše si mohou ve výuce dovolit rozhodnout, udělat a garantovat či slíbit, ale také samotné žáky a cvičného učitele. Tyto přidělené pravomoci týkající se odměňovací moci nejsou předem detailně nastavovány a vyjednávají se a rozhodují ad hoc během dění ve tř́ídě.

Zdá se, že studenti učitelství dostávají od cvičných učitelů „cvičné“, pozitivní výukové podmínky - nemusejí dávat žákưm špatné známky, dávají jen jedničky těm, kteří se v jejich hodinách snaží. Toto řešení je výhodné pro všechny tř̌ zúčastněné strany - žáky, studenty učitelství a cvičné učitele. Žáci mohou bez rizika neúspěchu zkoušet dostat jedničky. Studenti učitelství mohou mít lepší vztah $\mathrm{k}$ žákům ( $\mathrm{z}$ hlediska žákủ ${ }^{38}$ i sebe), jelikož je převážně odměňují. Zároveň se $\mathrm{v}$ chráněných podmínkách, jež nevedou $\mathrm{k}$ závažným důsledkům na straně žáků a kolizím žáků s učitelem, učí vytvářet písemky a testy a hodnotit z nich žáky.

38 Tomu nasvědčují i výsledky referenční báze moci: Studenti učitelství, i vlivem svého věku, mají z pohledu žáků vyšší referenční moc než učitelé (srov. Mareš et al., 2016, v přípravě). 
Cvičná paní učitelka má klasifikaci žáků podle sebe s pár plus body, které žáci získali od studentů učitelství, zajištuje tak konzistentnost známkování a jeho reliabilitu. Je však otázkou, zda si studenti učitelství na praxích v takto chráněných podmínkách procvičují hodnocení a klasifikování výsledků žáků, anebo se to pak budou muset učit, až nastoupí do profese.

\section{Vyjednávání o odměně mezi studenty učitelství a žáky}

Studenti učitelství nemohou známkami plně disponovat, což ukazuje na neúplné naplnění jejich role jako učitele a na neúplné naplnění potenciálu odměňovat v této roli. Jelikož je role studentů učitelství obvykle neúplná, co se týče odměňovací moci, je možné o ní vyjednávat. Nejasná pravidla udělování jedničky jsou i žákům, kteř́ také zjištují a doptávají se, jakými pravomocemi vlastně studentka učitelství na praxi disponuje a jak „velká“ či „malá“ je jednička, již nabízí (ukázka 46). Studentka odpovídá, že o velikosti jedničky nerozhoduje ona, ale jejich paní učitelka. Pak ale odpoví, že jednička bude do žákovské, což je pro žáka, který se ptá, už dostačující „velikost“ slibované odměny a opakování učiva na jedničky může začít. Ukazuje se, že žáci jedničky chtějí, což znamená, že známky naplňují odměňovací moc (ale i donucovací, srov. s. 97) studentů učitelství.

Ukázka $46^{39}$

Studentka Karla, výuka dějepisu, osmý ročník, opakování učiva

U: Začneme opakování. Já mám pro vás takové trošku malé překvapení. ((asi polovina žáků sleduje studentku))

U: Já budu klást otázky, vy budete správně odpovídat, předpokládám (učebnice zavřeme). Za správnou odpověd’ ode mě dostanete lísteček a za tři lístečky malou jedničku.

K: Kolik těch otázek bude? (.) Dvě?

K2: [Pan'čelko] (.) Pančelko... ((hlásí se))

U: Roman by chtěl něco říct...

K Roman: Pančelko, jen malou jedničku nebo velkou?

U: Paní učitelka ${ }^{40}$ si určí, jestli to bude moc malá nebo velká jednička.

K Roman: Ale bude to do žákovské?

K: [(hodně velká)]

U: Bude to do žákovské.

K Roman: Tak to jo, tak to jo.

Rozhodování cvičné paní učitelky, která učí dané žáky z daného předmětu, je dáno, předpokládáme, nutností zachování jednotnosti hodnocení prospěchu 
z daného předmětu, přičemž celkové hodnocení na konci pololetí dává právě cvičná učitelka. Studentka učitelství je ve škole jen na určitý omezený čas (tř̌i měsíce) a danou třídu učí jen několikrát (minimálně šestkrát $\mathrm{v}$ rámci našeho výzkumu). Z tohoto hlediska je logické, že jí nejsou propůjčeny všechny pravomoce, zejména ne ty, které by měly důsledky, jež by mohly vnést zmatek či nekonzistentnost do hodnocení žáků. Pokud bychom chtěli, aby se studenti učitelství mohli zapojit plně i do hodnocení žákủ, bylo by třeba, aby podmínky hodnocení a klasifikace výkonů žáků jasně vyjednali s cvičným učitelem, nezdá se však, že by $\mathrm{k}$ tomuto vyjednání a předání odměňovací moci docházelo $\mathrm{v}$ detailnější podobě v našem výzkumu. Odměňovací moc byla spíše intuitivně propůjčena na základě obvyklého úzu či zkráceného vyjednávání ve formě „můžete jim za to dát jedničky“. Je také možné, že toto povolení je krátkodobé a vázané na určitou činnost žáků a posléze v dalších hodinách znovu udělované cvičnou učitelkou.

Odměna ve výše uvedené ukázce 46 byla tedy objasněna a žákům stojí za to se pro ni snažit. Pravidla jsou jasná a závazná, žáci je nastavili (zkontrolovali) tak, aby je studentka učitelství a paní učitelka musely dodržet - byla explicitně a veřejně řečena všechna, jinak př́padně nejasné aspekty udělení jedničky (tj. jak velká ta jednička vlastně je) byly projednány. Studentka učitelství vlastně neví, jak bude paní učitelka jí udělené jedničky brát, co se týče jejich významu, žáci však vědí, že když jsou v žákovské, mají význam. Z ukázky se zdá, že žáci mají zájem o jedničky jako formu odměny, o dobrý prospěch. Jeho účinnost jako motivačního faktoru je dána tím, jakou hodnotu prospěch pro žáka má, a to z nejrůznějších důvodů - radost $\mathrm{z}$ úspěchu, radost, že to dokáží, přijetí na stř̌ední školu, vyznamenání, sbírání dobrých známek snadným způsobem, pochvala od rodičů aj.

Někdy si fungování odměny objasňuje i student učitelství, a to až v praxi. Studentka učitelství ve výše uvedené ukázce hovoří o překvapení, že žáci budou moci dostávat jedničku za správné odpovědi, přesněji možná, že ji budou dostávat na základě přidělení lístečkủ za správné odpovědi - za tři lístečky je jednička. Později se v dané situaci ukazuje, proč právě Roman tak důkladně zjištoval podmínky odměny (jedničky). Ví prakticky jako jediný většinu odpovědí a systém přidělování lístečků a jedničky za tř̀ lístečky se studentce učitelství bortí. Roman by měl totiž nárok na více jedniček z jedné oblasti učiva najednou. Vývoj situace se tedy stává skutečně překvapením jak pro studentku učitelství, tak pro žáky. Studentka učitelství se ve výuce pokusila vyzkoušet novou formu odměňování, která měla být pro žáky zajímavější, motivující, současně s tímto cílem se však dostala i do ad hoc řešení nezamýšlených důsledků svého pokusu.

\section{Ukázka 47}

Studentka Karla, výuka dějepisu, osmý ročník, opakování učiva

U: Dobře a prosinec 1982?

ŽZ̆: [nnn nnnn] 
K Roman: ((hlásí se)) To je to císařství.

U: Dobře. Šikula, sbírej klidně další. ((jde $k$ Romanovi $k$ lavici a podává mu listeček))

K Roman: Můžu mít klidně dvě jedničky? (A tři?)

U: Můžeš mít klidně dvě jedničky.

K: A z toho pak bude jedna velká.

U: Ták císařství bylo kolikáté?

Roman sbírá lístečky, jelikož zná odpovědi. Studentka učitelství mu slibuje, že může mít klidně šest lístečků a z nich dvě jedničky. Někdo z kluků zkouší navrhnout další část pravidel - že by ze dvou jedniček byla jedna velká. Studentka učitelství tuto poznámku přechází bez komentování, pravděpodobně tak dalece nemá svou hru domyšlenou. Jedná se tedy o velmi jasnou mocenskou situaci, do které vstupují žáci. Otázkou vždy je, co s ní dělá student učitelství? Nyní se vyhýbá rozhodnutí a explicitnímu nastavení pravidel. Pravidla se dále vyjednávají a upřesňují během realizace opakování/zkoušení v dané výuce (ukázka 48).

Ukázka 48

Studentka Karla, výuka dějepisu, osmý ročník, opakování učiva

U: Ták císařství bylo kolikáté?

ŽŽ (polovina třídy): ((hlásí se))

K: Třetí.

K: Druhý.

ŽŽ: ((ruch, hlahol, nnn)) (nevykřikujte)

U: (nnn, no tak) tak druhé bylo. (nnn... vní?)

K Roman: No druhý, to druhý, tak to byl ten Ludvík Napoleon.

U: ((jde k Romanovi k lavici)) A kolik trvalo? 52 bylo vyhlášeno a trvalo do?

K Roman: [trvaloó, padesát-]

K: To už je otázka navíc, na to nemáte právo.

$\check{\mathbf{Z}} \check{\mathrm{Z}}+\mathbf{U}:(($ ruch, smích $))$

U: Nebud' chytrej, otázky rozdávám já.

K4 a K5: ((ruch, smích))

U: Dobře, bude vědět někdo jinej? Tak do kdy trvalo druhé císařství?

Studentka učitelství dále upřesňuje pravidla. Žáci se mají hlásit, ne pokřikovat. Studentka učitelství nepřidělí lístek za odpověd’ na otázku, kterou položila, ale rozšiřuje ji, což žáci vnímají jako porušení pravidel odměňování učitelem („To už je otázka navíc, na to nemáte právo."), ovšem ne dostatečně projednaného pravidla. Studentka učitelství stanovuje mantinely: „Nebud’ chytrej, otázky rozdávám já, “ a odvolává se na svou legitimní moc nad žáky bez ohledu na logičnost argumentu žáků. Sahá po své legitimní moci dané z její role učitele, jež však může 
žáky silně demotivovat právě kvůli její nespravedlnosti. Později se ve třídě zvedá určitý chaos a mírné protesty. Pravidla jsou v průběhu zkoušení/opakování dále konstruována a specifikována (ukázka 49).

Ukázka 49

Studentka Karla, výuka dějepisu, osmý ročník, opakování učiva

U: Tak dokdy trvalo druhé císařství?

K5: 58.

U: Ale kuš, to si děláš srandu.

ŽZ̆: 54 !... 52! ((ruch))

K3: Pančelko, já to vím, můžu se podívat do sešitu?

U: Ne a nehádejte. (.) 1870.

Žáci odpovědi hádají, načež studentka učitelství zavádí (příp. zexplicitňuje) pravidlo, že nemají hádat. Žáci se v plně rozjetém opakování ptají studentky učitelství, zda se mohou dívat do sešitu. Nepodívali se tedy bez souhlasu studentky učitelství, tj. aniž by bylo pravidlo explicitně řečeno (resp. zrušeno vzhledem k tomu, že se nepodívali). Jsou zvyklí, že obvykle platí pravidlo nedívat se do učebnice a sešitu při zkoušení a zjištují, zda (vedle zavření učebnice, které studentka nařídila na začátku) platí i pravidlo zavření sešitu. To odpovídá implicitním pravidli̊m ve školní třídě popsaným v kapitole 4.3.1.

Situace se dramatizuje, studentka učitelství si uvědomuje, že Roman se stále hlásí a ví odpovědi a měl by moc jedniček. Tento problém řeší tak, že se od začátku snaží vyvolávat i jiné žáky, nyní však mají již před Romanem vždy přednost (ukázka 50). Když se nikdo kromě Romana nehlásí, studentka učitelství čeká, jestli se přeci jen někdo jiný nepřihlásí. Takto řeší podobnou situaci běžně i zkušení učitelé, studentka $s$ ní má nejspíše vlastní zkušenosti ze školy nebo je toto řešení přirozeně logické.

\section{Ukázka 50}

Studentka Karla, výuka dějepisu, osmý ročník, opakování učiva

U: Přesunem se dál, revoluce v Itálii: o co jim šlo?

K Roman: ((hlásíse))

U: Šmankote, ten bude mít jedniček.

K Roman: O samostatnost.

ŽŽ: ((hlásí se, zvedají se))

U: O samostatnost ne, trošku jiná odpověd. ((otáčí se na dívku v zadní lavici))

Studentka učitelství, když žáci mluví bez přihlášení, připomíná pravidla: „A nevykřikujeme, hlásíme se, vyvolávám.“ Apeluje na dodržování žákovského 
registru, do něhož bezpodmínečně v obvyklé výuce patří zásada správného načasování repliky, když ji žák nedodrží, nepodaří se mu do výuky vůbec zapojit (srov. Šed’ová, 2009). Zavádí také nové explicitní pravidlo, že Roman má počkat, jestli se nepřihlásí ještě někdo jiný, že už má lístečků hodně (ukázka 51).

\section{Ukázka 51}

Studentka Karla, výuka dějepisu, osmý ročník, opakování učiva

U: Jaro 1848 Frankfurt nad Mohanem?

K Roman: ((hlásí se jako jediný)) že -

ŽŽ: [Jó! Eh! Uh! Tó!]

U: Počkej moment, jestli se ještě někdo přihlásí, já vím, že ty už máš těch lístečků hodně.

\section{ŽŽ: ((mrmlají slabě, nehlásí se))}

K: Tak už ho vyvolejte, nikdo jinej to neví.

U: (3) Takže?

K Roman: Parlament, sociální parlament.

U: Výborně. ((jde k Romanovi a podává mu lísteček))

D: Ty seš na ty jedničky?

Žáci opět diskutují se studentkou učitelství o nově zavedeném pravidlu (ukázka 51), že Roman má počkat: „Tak už ho vyvolejte, nikdo jinej to neví.“ Studentka po výzvě čeká a nakonec Romana, který se hlásí jako jediný, vyvolává. V tomto smyslu je i vyvolání odměnou, pozdržovanou, př́padně odpíranou odměnou a poskytnutou jen proto, že nebylo vyhnutí, proti vůli studentky učitelství, jen musela dodržet implicitní pravidlo. Zde si tedy uplatnění odměňovací moci studentky učitelství vynucují žáci. Dívky pak Romana popichují, zda „je na ty jedničky“, a vytváŕí tak na něho sociální nátlak, aby se možná tolik nehlásil. Pravděpodobně mu nepřejí až tak extrémní počet jedniček najednou a poukazují na absurdnost situace.

Žáci opět porušují pravidla a mluví bez přihlášení a vyvolání. Studentka učitelství se důsledně drží svého rozhodnutí, že lístečky dává jen těm, kteří se přihlásí a odpoví správně (ukázka 52).

\section{Ukázka 52}

Studentka Karla, výuka dějepisu, osmý ročník, opakování učiva

U: A o co šlo parlamentu?

Ž: (konec nnn)

U: Proč se parlament sešel?

K: (německý spor)

DD: ((smích)) (to řekl Matěj) 
U: O co šlo tam? Byla absolutistická monarchie a chtěli co?

K (Matěje): [(Já jsem to řekl první)]

D: Chtěli novou ústavu.

U: Dobře a proč se nepřihlášíšs! ((intonace))

K Roman, K2, K3, K4: ((hlásí se)) [Já vím co!]

K3: Pančelko, já vim co! Chtěli novou ústavu.

ŽŽ: ((smích))

U: Bohužel.

K3: $\mathrm{CO}$ ?!

U: Bez lístečku - už to bylo řečeno.

K3: Ale... ((máchne rukama)).

K Roman, ŽZ̆: (no, ale...) [nnn] (no, dobrý no)

Další žák, co se hlásí, tedy vykřikne bez vyvolání správnou odpověd, ale studentka učitelství odmítne dát mu lísteček, protože odpověd' již zazněla. Žáci projevují jemnou nevoli, ale zdá se, že tu logiku chápou. Samotné přihlášení se nestačí, je třeba být ještě vyvolán. Dochází tak k další specifikaci pravidel vyjednávaných v průběhu dění (ukázka 52).

Roman se vzhledem k četnosti svých odpovědí rozhoduje, že si bude pro lístečky chodit sám, aby mu je studentka učitelství nemusela nosit (ukázka 53). Zjištuje také, zda doplňující otázka bude za stejný nebo další lísteček, dříve než odpoví, jelikož neví, jak s těmito doplňujícími otázkami studentka učitelství systematicky zachází.

\section{Ukázka 53}

Studentka Karla, výuka dějepisu, osmý ročník, opakování učiva

U: Ještě dvě věci: jestli zahrnujou i České země do té koncepce a nebo (nnn) jak se tomu rríká?

K3: ((hlásí se a je vyvolán)) Ano.

ŽŽ: ((smích))

K Roman: ((hlásí se)) Velkoněmecká koncepce.

U: Ano, Velkoněmecká koncepce ((jde $k$ němu)) a ta druhá byla? ((dává mu lísteček))

K Roman: Já už si pro to budu chodit. ((jde k ní))

U: Ano, a ta druhá byla? Ten protiklad?

K Roman: A to ještě za tenhle lísteček?

K Roman + ŽZ̆: (nnn) [Fakt?]

K Roman: Velkoněmecká koncepce á (nnn) maloněmecká koncepce.

U: Dobře. Ústava byla přijata, nebyla přijata?

K Roman ((snaží se přihlásit)) + K3: ((bez hlášení)) Byla.

KK: Nebyla [byla], nebyla Ježiši marjá!

U: Takže zase nic, nebude listeček. Ústava nebyla přijata, respektive byla 
vytvořena, ale nebylo, kdo by se ujal svrchované vlády, takže vzniklo povstání. Kdo ho potlačil?

K Roman: ((snaží se hlásit)) Já vím. (2) Pančelko, prosím!

U: ((rozhliží se)) Ještě někdo? (3)

K3: ((hlásíse))

U: Víme? (na K3)

K3: Ludvík Napoleon?

$\mathrm{U}: \mathrm{Ne}$.

K Roman ((dál se hlásí ve stoje)): já vím... Rusko.

U: Rusko? ((jde k němu)) A kdo?

K Roman: Ten Fridrich, velký.

K: ((vykřikuje)) Fridrich Vilém.

U: ((dává mu lísteček)) Fridrich Vilém... Já vím, že všechna ta jména je pro vás těžké si zapamatovat.

Roman se hlásí a studentka učitelství se rozhlíží, zda se nehlásí i někdo jiný, koho by bylo možné vyvolat (bylo zavedeno pravidlo nehádání odpovědi, přihlášení se a vyvolávání). Roman zvyšuje svůj nátlak na studentku učitelství, aby ho vyvolala tím, že si již stoupá při hlášení se (ukázka 53). Nakonec odpovídá Roman, studentka učitelství dává doplňující otázku a lísteček za ni žákovi, který vykřikl.

Po dalších otázkách a odpovědích studentka učitelství napomíná dalšího žáka: „Co kdybys mluvil, až když tě vyvolám?“ Také v dalším pokračování situace vykřikující žák nedostává lísteček (ukázka 54). Žáci na studentku učitelství pokřikují, komu má dát lísteček a Roman ji prosí, aby ho znovu vyvolala, ona tak činí a Roman dostává další lísteček. Žáci pak chtějí, aby mu lístečky už nedávala. Studentka učitelství argumentuje: „Ale proč? Snaží se!“ a obrátí dlaň vzhůru ve smyslu prostě to tak je se slovy: „To je proto, abyste se snažili vy.“ Žák to zkouší dál: „V̌̌dyt se snažím.“ Studentka učitelství odpovídá, že to ví.

Ukázka 54

Studentka Karla, výuka dějepisu, osmý ročník, opakování učiva

K Roman: [Pančelko, já to vím.]

K5: ((hlásí se a je vyvolán)) Dolní a Horní Rakousy, Chorvatsko a Uhersko.

U: To je sice hezký ale ((na K5))

K Roman: [Pančelko, prosim!]

K4: Dejte mu lísteček! ((ukazuje gestem na K5)) A mě paní učitelko jeden taky.

K Roman: Prosím, prosím! ((je vyvolán)) Rakousko-Uhersko: Uhry, Rakousko a země české.

K5: [A jo takhle (nnn)]

U: ((dává Romanovi lísteček)) Musíte umět správně formulovat odpověd! 
((vrací se ke katedře, stojí před dètmi a mluví zároveň s nimi)) (nnn)

K: Tak už mu to nedávejte.

U: [Řekla jsem tři celkem.] Ale proč? Snaží se! ((obrátí dlaň vzhưru = prostě to tak je)) To je proto, abyste se snažili vy.

K: [V̌̌dyt] se snažim.

U: No, já vím.

Jeden z žáků volí strategii hlášení se a vykřikování při hlášení, do toho navíc vykřrikují ostatní žáci. Studentka učitelství jeho strategii zamítá a žák bouchne rukama o stehna na protest vůči pravidlu, které nebylo explicitní. Navíc je zavedeno nové pravidlo, že když vykřikují ostatní, nebudou se lístečky dávat (ukázka 55).

Ukázka 55

Studentka Karla, výuka dějepisu, osmý ročník, opakování učiva

U: Tak, kdo četl, kolik bylo národů v té Habsburské mon-?

K: Jó, tak těch bylo.

ŽŽ: ((hlásí se asi 5 a někteři prótom vykřrikují)) 30! (.) 17! 13! Já vim! 12! Tady, Pančelko já se hlásim. [17!]

U: [Vykřrikujete.] Bylo jich 17.

K5: No a co jsem řikal! ((bouchne rukama o stehna))

$\mathrm{U}:[$ Vykřikujete.]

V dalším dění studentka učitelství opětovně připomíná, že se žáci musejí hlásit: „A nevykřikujeme, hlásíme se, že chlapci.“ „Ale zase se nehlásíte!“ Žáci i přes opětovná upozornění na hlášení se často nehlásí a překřikují se s odpovědmi, mnohdy chybnými.

\section{Ukázka 56}

Studentka Karla, výuka dějepisu, osmý ročník, opakování učiva

U: Dobře. V záŕí 1848 bylo zrušeno:

ŽŽ: Nevolnictví!!

U: Ale zase se nehlásíte!

K5: Já první jsem se hlásil! ((hlásí se)) (nnn nnn nnn)

U: [nehlásili jste se]

K4: ((hlásí se a zase ruku pokládá, dívá se na kameramana))

K(5): Já bych to vykřikl taky. (nnn)

Studentka učitelství odmítá přijímat odpovědi z důvodu nehlášení se a vykřikování (ukázka 56). Jeden z žáků zkouší zavést pravidlo, že má být vyvolán ten, kdo se hlásí první, když není vyvolán a někdo odpověd’ vykřikne, komentuje 
situaci, že by taky mohl vykřiknout. Studentka argumentuje tím, že se nehlásí, žáci, co se hlásili, pokládají rezignovaně a naštvaně ruku. Jeden z žáků hledá oporu v kameramanovi, nejspiše s očekáváním, že by se jako dospělý, možná dohled, mohl vyjádřit $\mathrm{k}$ situaci a dát mu za pravdu.

Další žák (K4) říká studentce učitelství, že odpověd” na další otázku ví: „Ale klidně se na to zeptejte, já to vim.“ Ona ho vyzývá, aby se tedy přihlásil: „Tak se přihlas, ptám se." Další žák K5 se rozčiluje nad tím, že žák K4 jen říká, že to ví, ale hlásit se nemůže, protože to neví. Opět se hlásí Roman, je vyvolán, zná správnou odpověd' a dostává další lísteček. Dva žáci ho začínají podezírat, že má na lavici učebnici. Paní učitelka to jde ověrit, Roman tam má fyziku. Dostává př́ikaz ji schovat. Na další otázku se žáci hlásí (včetně Romana a K5) a žák K5 odpověd’ vykřikne. Studentka Karla mu ř́ká, že odpověd” má správně, ale „zase vykřikuješ, já jsem ti nedala slovo, až budeš vyvolanej, dobře“. Žák K5 si rozčíleně plácne dlaní do lokte. Petr se hlásí, i když vlastně neví pořádně odpověd’ a dělá si ze situace legraci. Odpovídá, že palácový převrat byl převrat a žáci se smějí. Hlásí se další žák K4: „Já vim, já vim.“ Petr ho bouchne zezadu: „Drž hubu! Hovno víš." Ukazuje se, že skutečně správnou odpověd' nevěděl. Petr protestuje, má méně lístečků než kolik by měl podle jeho názoru mít, měl by mít čtyři a nemá žádný (ukázka 57).

\section{Ukázka 57}

Studentka Karla, výuka dějepisu, osmý ročník, opakování učiva

U: Koho za koho?

D: ((hlásí se)) Ferdinanda za Františka.

U: Počkat a češtinářsky je to správně? Ferdinanda za Františka nebo Františka za Ferdinanda?

((dává lístek $D))$

K: [Není.]

K Petr: [Ona neví, pančelko, dejte to mě.] Jasný. Já už jsem měl mít 4 aspoň.

K3: Petře, kolik jich máš?

K Petr: Nula.

Studentka Karla nabízí také lísteček za téma, které ještě nebrali. Chce zjistit, zda již dané téma brali: „Dobře, takže tohle jste si ještě neříkali, já jsem potřebovala zjistit, jestli jste si to už rríkali. " Porušuje tak vlastně implicitní pravidla tohoto způsobu opakování/zkoušení známého učiva. Důsledky však nejsou závažné, nikdo neví, takže nikdo nedostává lísteček a situace je pro všechny žáky z hlediska odměny spravedlivá, tudíž se vůči ní neohrazují jako vůči předchozím zexplicitňováním pravidel.

Opakování na lístečky a jedničky je skončeno, Petr se domáhá další otázky prosebným tónem. Kdo má tři lístečky, může si zapsat téma a jedničku do žákovské a nechat si to podepsat po výuce. Roman diskutuje s cvičnou paní učitelkou, že tři jedničky vypadají líp než jedna velká (ukázka 58). 


\section{Ukázka 58}

Studentka Karla, výuka dějepisu, osmý ročník, opakování učiva

K Petr: Pančelko, další otázka. ((prosebným tónem)) (nnn)

U: Končím, spočítejte si lístečky. Kdo má víc jak 3 lístečky, tak si

K Petr: [Měl jsem mít 4, ale. ((zvedá se a bere K4 pouzdro z ruky)) (nnn)]

U: ...(do žákovské knížky napíše dnešní datum a při nnn) revoluční rok, opakování

K Roman: [takže pančelko, já mám 3 jedničky]

K4: ((háže perem, zvedá se a jde si pro něj a zpět na místo))

U: A já si to pak vyberu.

K Roman: ((mluví s paní učitelkou vzadu)) Ale ty tři jedničky vypadají líp. Tak dobř̀e.

DD: ((otáčí se $k$ sobě, sdílí dojmy))

Tato dlouhá ukázka vyjednávání o odměně naznačuje, do jak rizikových situací z hlediska pravidel a legitimní moci se student učitelství dostává, zejména zkusí-li např́klad nějakou techniku odměňování, se kterou nemá zkušenosti. Ukazuje také, jak je odměňovací moc zasazena do legitimní moci, jež je studentovi učitelství pouze propůjčována.

Další ukázka 59 ukazuje, jak se žáci ujištují o podmínkách odměny a vyjednávají je, i když by jejich dotaz učitel mohl považovat za absurdní. Tak se např́klad ptá žákyně studentky učitelství Lenky, jestli dostane jedničku, na niž mají nárok tři první, i když bude mít odpovědi špatně.

\section{Ukázka 59}

Studentka Lenka, výuka dějepisu, druhá hodina, osmý ročník, opakování

U: Nejdřív dostanete ted'ka pracovní list. Necháte ho položený, položený textem dolu, protože první cvičení je na opakování toho, jak nám vlastně Spojené (.) Spojené státy americké vznikly. Takže, když dám instrukce, leží vám papír takhle ((ukazuje)) a až řeknu ted, otočíte. První tři, co budou mít doplněno, dostávají jedničku. Použít můžete učebnice, sešity, cokoliv, prostě jakýkoliv informační (.) informační zdroj. Jo, můžeš rozdat. ((dává žákyni na rozdání pracovní listy))

D: Musí to být správně odpovězeno?

U: No samozřejmě, musí to být správně odpovězeno. Všechny informace naleznete (.) naleznete určitě ve své učebnici.

Studentka Lenka chodí po třídě a dívá se žákům do písemky, když mají něco špatně nebo jim něco chybí, doporučuje jim, at to opraví či doplní, aby měli na jedničku nárok: „Toho prezidenta si zkontroluj. Ještě pořád je šance“. Zde se 
opět projevuje zájem studentky učitelství na tom, aby žáci získali jedničku, aby mohli v její výuce zažívat úspěch. $V$ kapitole 4.5 o expertní moci popisujeme situace, $z$ nichž vyplývá, že žáci vnímají jako experty ty, kteří jim umožní zažít úspěch (respektive, že experti umožňují zažít úspěch), což může vysvětlovat do jisté míry i to, proč chtějí studenti učitelství jedničky rozdávat.

Studentka Lenka se dále snaží motivovat žáky k rychlému řešení úkolu zbývajícími jedničkami: „Ukaž, já ti dám jedničku. Tak odevzdávám. Mám dvě, tak ještě jeden!“ Pravidla v tomto př́padě byla jasněji a jednodušeji nastavena než v situaci s přidělováním lístečků u studentky učitelství Karly (ukázky 46-58), nedochází tedy $\mathrm{k}$ dalšímu vyjednávání či nevoli žáků. Jedničku však nakonec také neuděluje studentka učitelství, ale cvičná učitelka (ukázka 60).

Ukázka 60

Studentka Lenka, výuka dějepisu, druhá hodina, osmý ročník, opakování

U: Ukončíme to. Tak já vám děkuju, přiště budeme pokračovat. Doufám, že (nnn).

CU: Já jsem se nestačila divit.

K: Co ty známky?

CU: Kluci, známky vám zapíšu.

\section{Paralelní vyjednávání žáků se dvěma učiteli}

Vyjednávání o odměně neprobíhá ve výuce studentů učitelství jen mezi studenty učitelství a žáky, ale tím, jak není odměňovací moc studentům plně propůjčená, probíhá nadále paralelně také mezi cvičnou učitelkou a žáky. Paní učitelka motivuje žáka k práci ve výuce dějepisu studentky učitelství Lenky přislíbením jedničky: „Miláčku, pokud to budeš mít, tak ti dám jedničku." Další žáci okamžitě zjištují, zda by stejné podmínky udělení odměny platily i pro ně a vyjednávají tak s paní učitelkou: „Mně taky?“

\subsubsection{Za odměnu zajímavosti?}

Studenti učitelství motivují žáky někdy také přislíbením určité aktivity, která je pro žáky zajímavá. Slibují obvykle, že když zbyde čas, budou říkat zajímavosti, pustí video atd. Při realizaci těchto slibů pak těmito zajímavostmi žáky i odměňují. Ve skutečnosti je však otázkou, zdali se jedná o odměnu v pravém slova smyslu, jelikož často není jasné, za co odměna je. Jedná se primárně o motivaci žáků, aby výuku vydrželi, že nebude tak namáhavá, že se dozvědí něco, co by je mohlo (opravdu) zajímat atd. ${ }^{41}$ Např́iklad studentka Zdena ve výuce českého jazyka

41 V kapitole 4.3.4 (s. 101) o donucovací moci popisujeme preventivní miniscénář „ulovím vás na didaktickou udičku“ studentů učitelství, který ukazuje, jak se studenti snaží žáky přrimět například pomocí učiva ke sledování výuky a participaci na ní. 
v šestém ročníku slibuje: „Určitě si zapamatujete i Cestu kolem světa za 80 dní (o Willy Fogovi), kterého si možná pustíme, pokud zbyde čas“. Studentka Lenka v dějepise v osmém ročníku říká na začátku hodiny žákům: „Budeme pracovat s pracovním listem, s atlasy, a když zbyde čas, tak tady jsou i nějaké zajímavosti, takže vám můžu říct i nějaké zajímavosti“. Na konci hodiny čas zbyl a studentka své slovo dodržela, ř́ká žákům zajímavosti, které se týkají probraného učiva: ukazuje, jak Bismark správně předvídal, jak válka dopadne a jak byl třikrát postřelen, ale nic se mu nestalo, jelikož nosil neprůstřelnou vestu, což bylo na tu dobu nevídané. Otázkou je, zda je tato odměna jako odměna vnímána i žáky. Takovéto přislíbení nějaké zajímavosti učitelé používají nejen jako motivaci žákůa ale i jako odměnu za dobrou práci, dobré výsledky, dobré chování.

\subsubsection{Za odměnu speciální podmínky?}

Do odměňovací moci učitele spadá i to, že může žákovi či žákům umožnit určité speciální podmínky, například jim mủže nechat více času na test, dát jim více času na rozmyšlenou na odpověd či jim pomoci, když jim nejde řešit úkol. Podobně jako u slíbení zajímavostí, i zde je otázkou, zda tuto formu odměňovací moci jako formu odměňovací moci skutečně prezentovat, $\mathrm{v}$ situacích, kdy není konkrétní důvod, za co jsou žák nebo třída odměněni, a jedná se tak spíše o podporu učení a práce žáků. Např́ílad studentka učitelství Lenka nechala žákům více času na test na podnět cvičné paní učitelky. Studentka Alice v občanské výchově v osmém ročníku nechala žákovi víc času na rozmyšlenou: „Zase to nejde? Tak si to zkus rozmyslet chvilku“. Studentka Lenka v dějepise pomáhala žákům s řešením pracovního listu, když si nevěděli rady nebo umožnila žákům kontrolu chyb, aby mohli dostat jedničku.

Jako určitý typ odměny lze vnímat také to, že žáci, kteří jsou dříve hotoví, dostávají speciální úkol, případně mohou začít s dalším úkolem dříve. Studentka Zdena tak ve výuce českého jazyka v šesté tř́dě říká žákům, že „kdo už má dopsáno, tak si mezitím najde ukázku v čítance na straně sto čtrnáct“. Žáci, kteří jsou hotoví, si otevírají čítanku a studentka čeká na zbylé, kteří písíi. Odměnou je tato situace jen za určitých podmínek, např. když je to prestižní v dané třídě. Jinak toto řešení může působit naopak jako trest za dobrý výkon.

Za projev odměňovací moci studentů učitelství můžeme také považovat, když přislíbí nějakou úlevu $\mathrm{z}$ náročného dne či výuky, například, že žáci nebudou muset $\mathrm{v}$ dané hodině tolik pracovat. Studentka Lenka v dějepise v osmém ročníku motivuje žáky následovně: „Takže dneska budeme zase pracovat s pracovním listem a mám pro vás nachystána dvě videa, takže budete mít i trochu takový odpočinek. Nebudete muset ... muset toho př́liš ... př́liš dělat". Snaha studentů učitelství motivovat těmito úlevami žáky, může ukazovat na to, že je žáci vítají či vyžadují, což může souviset mimo jiné s efektem tzv. kolonizace (Hammersley \& Woods, 1984), kdy žáci přijímají školní normy a postoje, ale za účelem naplnění vlastních cílů, 
například vyhnutí se zkoušení či probírání nového učiva (více kap. 2.2). Podobně mohou fungovat i udělované zajímavosti (viz předchozí kap. 4.4.1.3).

Určitou formou odměny žákům je i souhlas studenta učitelství s realizací nějaké činnosti, o kterou žák studenta učitelství žádá. Vyhovění žádosti žáka je pravděpodobně také odměnou za předchozí či aktuální chování (včetně např̀ formy dotazu) v souladu s implicitními výukovými pravidly. Např́iklad ve výuce českého jazyka studentky Zdeny v šestém ročníku se žákyně Nikola ptá, jestli může ostatním poslat obrázek. Studentka Zdena souhlasí: „Dobře, můžeš poslat. At si prohlídnou spolužáci.“

I o speciálních podmínkách žáci zkouší se studenty učitelství vyjednávat. V ukázce 61 se žák pokouší o to, aby jim studentka dala volnou hodinu, když cvičná učitelka je nemocná a studentka převzala výuku kompletně sama až do konce své praxe. Studentka se nepouští do vyjednávání a sahá ke své legitimní a donucovací moci a pokračuje $\mathrm{v}$ instrukcích $\mathrm{k}$ úkolu.

\section{Ukázka 61}

Studentka Petra, výuka českého jazyka, třetí hodina, sedmý ročník

U: Tak dneska na začátku hodiny si uděláme menší gramatické cvičení na zopakování.

K Michal: Volná hodina.

U: Ne, volná hodina nebude.

K Michal: Vždyt je pátek.

U: A to pravopisné cvičení si zkontrolujeme, zopakujeme si slovesný rod a budeme ho procvičovat.

K Michal: Ach jo.

U: Takže si vemte sešity do mluvnice.

\subsubsection{Poděkování žákům za pomoc a dobrou práci}

Nemateriální formou odměny žákům od učitele je také poděkování žákovi za pomoc a spolupráci. Studenti učitelství (jako v běžné komunikaci) děkují žákủm, když jim pomohou např. něco rozdat (test, atlasy apod.), nebo otevř́ít okno na žádost studenta učitelství, poradí jim v něčem, co nevědí (např. když se ztratí při čtení, $\mathrm{v}$ učivu). Poděkování se objevuje také například, když žáci předávají testy, když žáci přečetli kousek literární ukázky apod. Poděkování za odpověd' či za spolupráci se vyskytuje především $\mathrm{v}$ obvyklé struktuře vyučovací hodiny IRF: otázka učitele - odpověd žáka - reakce učitele „děkuji“, která zde má funkci potvrzení správnosti a uzavření situace. Tyto výskyty forem poděkování žákovi jsou v datech časté, v závislosti na stylu formulování zpětné vazby jednotlivých studentů učitelství na konci IRF struktury.

Ne každé „děkuji“ je učitelem míněno jako poděkování, někdy se jedná o ironii, kterou žáci odlišují na základě kontextu, např̀. intonace. Ironické vyznění (ne 
však nutně) může mít poděkování žákům, např́klad za to, že se na žádost učitele ztišili: „Tak, můžu prosím mluvit? ... Děkuji“ (studentka Alice).

Formou odměny žáků vyskytující se $\mathrm{v}$ našich datech studentů učitelství na praxích je také poděkování celé třídě za spolupráci na konci hodiny, př́padně po ukončení určité aktivity. Studentka Věra se loučí při zvonění slovy: „Děkuji, na shledanou." Poděkování je často spojeno s pochvalou třídy (viz další kapitola 4.4.1.6). Ve výuce studentky učitelství Lenky její ukončovací poděkování („Tak já vám děkuju. Přriště teda písemka nebude zase a př́šstě vám řeknu, co bude v té další.") doplňuje cvičná učitelka, např. s dotazem, zda si může vzít slovo, a pokračuje v krátkém vedení hodiny na chvíli po zvonění - opakuje na test, který je další hodinu, v jiném př́ípadě např́iklad řeší organizační záležitosti.

\subsubsection{Pochvala za splnění úkolu a za dobrou práci}

Studenti učitelství pracují ve své výuce na praxi také s pochvalou žáků za splnění úkolu coby s formou odměňovací moci. Např́iklad studentka Alice ve výuce občanské výchovy v osmém ročníku např́klad chválila žáky, že dodrželi budto explicitní, či implicitní pravidlo - že se na začátku hodiny sami rozesadili na písemku po jednom: „Výborně jste se rozsadili po jednom. A já vám, rozdám zadání“. Studentka učitelství Zdena chválí žákyni za její práci - za přečtení si literárního díla, resp. splnění domácího úkolu. Ostatní žáci moc nečetli díla, co měli, nebo si je nepamatují. Studentka učitelství pak oceňuje aktivitu žákyně, která dílo četla (ukázka 62).

Ukázka 62

Studentka Zdena, výuka českého jazyka, druhá hodina, šestý ročník, prezentace přčtených literárních děl

U: Velmi dobře. A zjištovalas třeba, jak skončila kniha nebo jako celá. Nebo nečetlas, jenom tu ukázku.

D: Jenom jsem četla to, co jsme měli dočíst.

U: Dobře. Výborně, takže tebe chválím.

Pochvala před spolužáky může také pro určité žáky nebýt pochvalou, odměnou, protože ukazuje, že žák spolupracuje s učitelem, což nemusí být v dané sociální skupině vždy ceněno.

Také u pochval za splnění úkolu dochází k vyjednávání mezi učitelem a žáky. V následující ukázce 63 se žákovské vyjednávání o pochvale projevuje nepřímo - studentka učitelství uzná snahu dívky na její podnět. Jedná se o situaci, kdy studentka učitelství poradila žákům, jak si opravit test, aby mohli získat jedničku. 


\section{Ukázka 63}

Studentka Lenka, výuka dějepisu, druhá hodina, osmý ročník

U: ((vrací žákovi úkol)) No, ještě bych (.) ještě bych tady změnila, změnila toto slovo.

D: To je moje. ((vymění úkoly se spolužákem))

U: Tak to máte oba.

ŽŽ: ((žáci pišou))

U: Špatněs to opsala.

D: Sakra.

ŽZ̆: ((smích))

U: To je Jakub, že jo?

D: Ale paní učitelko, já jsem to zvládla celý sama.

U: To já oceňuju.

Formou odměny žáků vyskytující se $\mathrm{v}$ našich datech studentů učitelství na praxích je také poděkování celé třídě za spolupráci na konci hodiny, př́padně po ukončení určité aktivity, které je spojeno s pochvalou celé tř́́dy. Studentka Milena na konci hodiny občanské výchovy v osmém ročníku ř́ká: „Tak my se ještě pozdravíme ještě na závěr. Já vám děkuju. Pěkně jste pracovali a uvidíme se zase zítra. Máte přestávku a služba smaže tabuli“. Podobně studentka Alice říká: „Já vám dneska děkuji za práci, pracovali jste moc pěkně..." Také studentka Zdena žáky na konci hodiny českého jazyka v šestém ročníku chválí: „Tak tady prozatím skončíme, dneska vás musím velice pochválit. Hezky jste všichni četli“. Tyto formulace mohou také mít efekt pozitivních sebenaplňujících se očekávání (srov. kap. 4.4.1.1) motivujících žáky a zavazujících je $\mathrm{k}$ naplnění pozitivních představ učitele o jejich osobě, především za předpokladu, že disponuje silnou referenční, popř. expertní mocí.

\subsubsection{Odměňovací moc studenta učitelství z pohledu žáků}

Na odměňovací moc jsme nahliželi nejen prostřednictvím nepř́mého (a přímého) pozorování výuky studentů učitelství, deníků a rozhovorů, ale také prostř̌ednictvím dotazníkových výpovědí žáků sbíraných po šesti hodinách výuky studenta učitelství v dané třídě. Žáci odpovídali na pětibodové škále měřící míru souhlasu s celkem osmi výroky vyjadřujícími možné uplatňované formy odměňovací báze moci studenta učitelství na dlouhodobé praxi (viz tab. 8, s. 134).

Výsledky žáků, resp. zkoumaných osmi studentů učitelství, porovnáváme s výsledky 96 studentů učitelství Pedagogické fakulty Masarykovy univerzity na dlouhodobých učitelských praxích na druhém stupni základních škol, a to z pohledu 1686 vyučovaných žáků (více viz Vlčková, Mareš, \& Ježek, 2015). 


\section{Porovnání míry uplatňování odměňovací moci a ostatních mocenských bází}

Odměňovací báze moci je z pohledu žáků druhá nejvíce uplatňovaná báze moci studenty učitelství po bázi expertní (tab. 4, obr. 5 v kap. 4.1, s. 61), a to jak v našem vzorku osmi studentů učitelství, tak ve srovnávacím vzorku studentů PdF MU. U vzorku 96 studentů PdF MU byl tento rozdíl statisticky významný, nejednalo se však o náhodný výběr, proto je výsledek orientační.

Zkoumaných osm studentů učitelství uplatňovalo odměňovací moc nepatrně více (130 žáků, $\bar{x}=3,75, S D=0,79)$, než 96 studentů učitelství PdF MU (1686 žáků, $\bar{x}=3,53, S D=0,80$ ) ve srovnávacím výzkumu z roku 2014 (tab. 4, obr. 5 v kap. 4.1). Rozdíl není testován statisticky, jedná se o 0,22 bodu na odpovědové stupnici od 1 do 5 (souhlasím). Možná vysvětlení tohoto rozdílu byla naznačena v kapitole 4.1 na s. 62, jedná se například o vyšší hodnocení v položkách chválení žáků cvičné učitelce dané větším kontaktem s ní, motivovanost osmi zkoumaných studentů k učitelství, a tudíž pozitivní vztah k žákům či vliv natáčení.

\section{Porovnání uplatňování odměňovací moci u osmi zkoumaných studentı̊ učitelství}

Jednotliví zkoumaní studenti učitelství se lišili v průměrné míře uplatňování odměňovací báze moci ve sledovaných šesti vyučovacích hodinách na své praxi (rozdíl není testován statisticky). Míra používání odměňovací moci z pohledu žáků variovala v rozsahu od 3,40 po 4,35 průměru na pěti bodové škále, což ukazuje spíše na používání odměňovací moci (obr. 8).

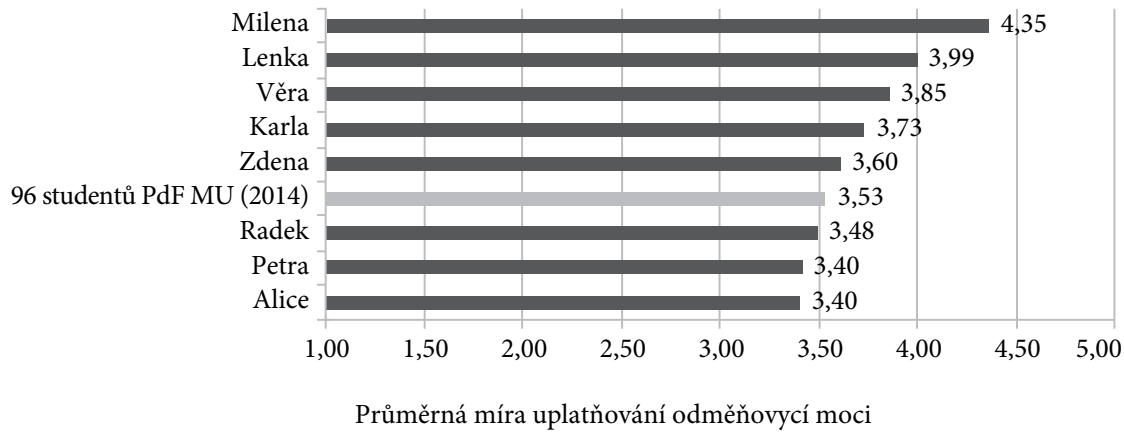

Poznámka. Odpovědová stupnice je od 1 do 5 (souhlasím).

Obrázek 8. Průměrná míra žáky reflektovaného užívání odměňovací moci studenty učitelství. 
Odpovídajíce odlišnostem mezi osmi zkoumanými studenty učitelství odpovídali žáci na jednotlivé měřené položky odměňovací báze moci (tab. 8).

\section{Tabulka 8}

Prưměrná míra žáky reflektovaného uživání forem odměňovací moci osmi studenty učitelství

\begin{tabular}{|c|c|c|c|c|c|c|c|c|c|c|}
\hline $\begin{array}{l}\text { Položky od- } \\
\text { měňovací báze } \\
\text { moci }\end{array}$ & 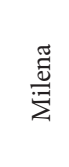 & 苟 & $\stackrel{\mathscr{\Xi}}{\rightleftarrows}$ & 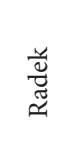 & 苞 & $\frac{\mathbb{Z}}{\mathbb{Z}}$ & $\frac{\pi}{\tilde{\Xi}}$ & $\stackrel{\pi}{\stackrel{0}{0}}$ & $\begin{array}{l}\text { Průměr } \\
\text { všech } \\
\text { osmi } \\
\text { studen- } \\
\text { tů }\end{array}$ & $\begin{array}{c}\text { Stu- } \\
\text { denti } \\
\text { PdF } \\
\text { MU } \\
2014\end{array}$ \\
\hline $\begin{array}{l}\text { O24: Když mi } \\
\text { to v hodině jde, } \\
\text { tato učitelka to } \\
\text { ocení. }\end{array}$ & 4,88 & 4,00 & 3,67 & 3,71 & 4,47 & 4,27 & 4,47 & 4,80 & 4,33 & 4,23 \\
\hline $\begin{array}{l}\text { O51: Když jsme } \\
\text { ve výuce téhle } \\
\text { učitelky hodní, } \\
\text { pochválí nás } \\
\text { naší učitelce. }\end{array}$ & 4,75 & 3,71 & 3,92 & 3,57 & 3,95 & 4,41 & 3,93 & 4,07 & 4,08 & 3,70 \\
\hline $\begin{array}{l}\text { O45: Když } \\
\text { se naučím, } \\
\text { co mám, tato } \\
\text { učitelka mě } \\
\text { pochválí. }\end{array}$ & 4,43 & 3,52 & 3,17 & 4,00 & 4,11 & 3,77 & 4,13 & 4,33 & 3,92 & 3,75 \\
\hline $\begin{array}{l}\text { O49: Když } \\
\text { v hodině dělám, } \\
\text { co tahle učitelka } \\
\text { chce, pochválí } \\
\text { mě za to. }\end{array}$ & 4,53 & 3,76 & 3,58 & 3,71 & 4,42 & 3,52 & 3,60 & 4,07 & 3,91 & 3,70 \\
\hline $\begin{array}{l}\text { O48: Když se } \\
\text { v hodině sna- } \\
\text { žím, je na mě } \\
\text { tato učitelka } \\
\text { hodnější. }\end{array}$ & 4,27 & 3,43 & 3,75 & 3,71 & 3,89 & 3,13 & 3,67 & 3,60 & 3,64 & 3,55 \\
\hline $\begin{array}{l}\text { O40: Když mi to } \\
\text { v hodině téhle } \\
\text { učitelky jde, } \\
\text { řekne to naší } \\
\text { učitelce. }\end{array}$ & 4,23 & 2,90 & 3,42 & 3,14 & 3,44 & 3,70 & 3,20 & 3,20 & 3,40 & 3,12 \\
\hline
\end{tabular}


O20: Když

vím ve výuce

něco navíc,

tahle učitelka to

3,00

3,25

2,86

3,83

3,45

3,47

3,14

3,39

3,37

vyzdvihne před

ostatními.

O38: Když se

v hodině cho-

vám tak, jak

tato učitelka

2,80

2,90

2,42

3,14

3,74

2,61

3,33

3,53

3,06

2,79

chce, nějak mě

odmění.

Ukazuje se (tab. 8), že jednotlivé formy odměňovací moci jsou studenty učitelství spíše využívány či silně využívány, alespoň tak to vidí žáci, a to bez ohledu na to, zda se jedná o primárně didaktický či regulativní diskurs. Z hlediska didaktického diskursu žáci reflektují (tab. 8), že zkoumaní studenti učitelství prakticky vždy oceňují (velmi vysoko s průměrem 4,33 na škále od 1 do 5 ), pokud to žákům ve výuce jde. Podobně je obvykle chválí, když se naučí, co mají. Platí také, že jsou na ně obvykle hodnější, když žáci ve výuce projevují snahu. A obvykle řeknou také studenti učitelství jejich paní učitelce, jestliže to někomu ve výuce šlo, přinejmenším se žáci domnívají, že to studenti učitelství dělají. Co se týče regulativního diskursu (tab. 8), obvykle je chválí jejich paní učitelce, když jsou ve výuce hodní. A chválí je také, pokud dělají to, co studenti učitelství chtějí. Odměňování za to, že se chovají, jak studenti učitelství chtějí, vychází spíše půl napůl.

Nejvyšší míru používání odměňovací báze moci reflektovali žáci u studentky Mileny, týkalo se to jak odměňovací báze jako celku, tak prakticky všech zkoumaných položek. Milena měla (kromě legitimní/donucovací moci, kde byla na druhém místě) z hlediska pohledu žáků nejvyšší míru uplatňování všech bází moci (srov. kap. 4.5 a 4.6).

\subsubsection{Shrnutí: Žák je odměňován, když hraje svoji roli žáka správně}

Odměňovací moc studenti učitelství uplatňují v miniscénárích vážících se nejčastěji na IRF strukturu vyučovací hodiny, která ve vyučovacích hodinách silně převládá (srov. Šed’ová, 2012). Odměny se tak vyskytují ve výuce v převážné většině především ve formě potvrzování správnosti odpovědi, méně často ve formě výraznější pochvaly za správnou odpověd’ nebo dalších forem odměňovací moci (poděkování za spolupráci, udělení jedničky apod.). Studenti učitelství využívali takových forem odměn, které nejsou primárně zdrojem pokřivení žákovské motivace k učení a výkonu, participace na výuce apod. Mnohé z možných forem a miniscénářů uplatňování odměňovací moci se v našich datech neobjevily, obvykle 
jsou vázané na neformální prostředí nebo nejsou v běžné výuce co do četnosti tak časté (např́iklad výlet za dobré chování, sladkosti apod.).

V porovnání s výsledky 96 studentů PdF MU jde vidět, že námi zkoumaných osm studentů učitelství využívá odměňovací moci více než je průměr studentů PdF MU z roku 2014, což se týká i každé jednotlivé zjištované podoby odměňovací moci. Tento výsledek je dán tím, že studenti učitelství měli pravděpodobně více kontaktu s cvičným učitelem a mohli mu žáky chválit, jak ukazují vyšší hodnoty u položek, které tyto aspekty měří. Výsledek může být dále ovlivněn také výběrem našeho vzorku osmi studentů učitelství pro natáčení výuky, kteří projevili souhlas s natáčením a byli osloveni na doporučení oborového didaktika, jedná se tedy spíše o šikovnější studenty učitelství (více viz také kap. 5). Roli také může hrát sama výzkumná situace natáčení výuky, kdy se studenti učitelství i žáci mohli chovat lépe než by tomu bylo bez záznamu jejich chování.

Formy odměňování měřené dotazníkem byly hodně obecné, z hlediska konstrukce dotazníku je tak možné je doplnit o položky zjištěné otevřeným kódováním videozáznamů, rozhovorů a deníků jako zdrojů dat. Nicméně v naší adaptaci dotazníku na studenty učitelství položky, které byly velmi specifické, námi navržené a vycházely z konkrétní školní reality v našich školách, pak v subškálách moci nefungovaly a museli jsme je následně vyřazovat.

Náš výzkum přináší také zajímavé výsledky týkající se provázanosti jednotlivých bází moci, referenční a odměňovací moci, expertní a odměňovací moci (viz i kap. 4.1). Jak bylo popsáno v kapitole o referenční moci (kap. 4.6), pro referenční osobu je současně snazší odměňovat, může tak činit zájmem či jiným projevem pozornosti, např. společnou činností, a přitom k tomu nemusí žáka pobízet nebo redukovat pojetí odměn na utilitární. Z hlediska žáků učitelé, kteří je více odměňují, jsou současně více experty (srov. kap. 4.5).

Analýza kvalitativních dat ukázala, že odměňovací moc studenta učitelství je orámována jeho legitimní mocí. Student učitelství může žáka odměňovat, pokud má propůjčenou legitimní moc, pak může např́klad udělit jedničku, i když zapsat ji zatím nemůže. Dojde-li na vyjednávání odměn, potřebuje mít student učitelství především díky propůjčené legitimní moci $\mathrm{k}$ dispozici př́ípadně také arzenál forem donucovací moci, kterými se odkazuje např́klad na žákovský rejstř́ik závazný ve výukové komunikaci. Co se týče potvrzování správnosti a oceňování správnosti odpovědí žáků, což je v běžné výuce nejfrekventovanější projev odměňovací moci, musí student učitelství současně disponovat také expertní a referenční mocí. S experty, již nejsou do určité nutné míry minimálním nutným referenčním bodem pro žáky, se žáci těžko identifikují, těžko se jim učí nápodobou jako jednou z nejrychlejších forem učení a hůřre se od nich mohou učit jemnější aspekty než jen znalosti. Provázanost bází moci se tak projevuje na mnoha subtilních i zřejmých úrovních a celkově lze říci, že „dobrý učitel žáky odměňuje“, resp. že jeho odměny žáci přijímají - dobrý učitel tedy používá odměny, které žáci chtějí. 
Žák je odměňován, když hraje svoji roli žáka správně. Současně však většina pravidel odměňování je ve výuce studentů učitelství implicitní, žáci je často neznají přesně a nevědí, co mohou čekat. Mají jen rámec z výuky svého učitele. Nejsou si jistí, zda známka udělená studentem učitelství (obvykle jen jedničky) je skutečně platná a zda se bude počítat. Zexplicitňování pravidel v průběhu výuky ad hoc postavených na obvyklém registru žáka žáky bouří, ne všechna pravidla jde však vyjmenovat před začátkem nějaké učební aktivity. Když jsme se ptali studentů učitelství, zda četli školní ŕád, nikdo ho nečetl, všichni předpokládali, že „se to tak nějak zná“ a že je to všude stejné. Stejně jsou na tom i žáci.

$\mathrm{V}$ naší knize, vzhledem $\mathrm{k}$ jejímu tematickému zaměření $\mathrm{z}$ hlediska analýz, nereflektujeme významnou část odměňovací moci jakožto relačního fenoménu, a to odměňování učitele žáky a odměňování se žákủ navzájem. V datech se např́íklad ukazovalo, že žák může studentovi učitelství pomáhat; může uposlechnout výzvy studenta učitelství (osobní přímé či nepřímé na celou třídu), což lze v jistém slova smyslu také chápat jako odměnu orámovanou legitimní mocí propůjčenou studentu učitelství, může se např́klad na výzvu studenta učitelství hlásit nebo používat techniky změny chování učitele (srov. Makovská, 2011). Žáci také $\mathrm{v}$ určitých př́padech vyjadřovali nadšení $\mathrm{z}$ aktivity studentky učitelství či děkovali studentce za výuku. Z hlediska mocenského vztahu žáka k žákovi se objevovalo např́klad oceňování spolužáka. Tyto a další formy by bylo také vhodné bliže analyzovat a popsat. Jejich popis se vyskytuje $\mathrm{v}$ pedagogické teorii a výzkumu vzácněji než popis odměňování učitelem, i když komplexní výsledky k odměňovací moci na druhém stupni základní školy, navíc v českých podmínkách a ještě u studentů učitelství nejsou př́mo $\mathrm{k}$ dispozici. 


\title{
4.5 Expertní báze moci aneb Dobrý učitel jako mistr svého řemesla
}

\author{
Zuzana Šalamounová
}

V této kapitole se věnujeme expertní bázi moci, což znamená, že popisujeme mocenské vztahy, jejichž podoba závisí na tom, nakolik žáci ne/vnímají studenty učitelství jako experty a nakolik naopak studenti učitelství ne/vnímají jako experty žáky, u nichž realizují svoji praxi (viz kapitola 2.6.4). Uvedli jsme, že mocenské vztahy ve školní třídě nemají fixní podobu, ale mohou se naopak proteovsky proměňovat, což platí také s ohledem na expertní bázi moci. Podrobnější pohled však prozradí, že ačkoli mocenské uspořádání ve třídách variuje, jeho variabilita je systematická. V postupech jednotlivých studentů i žáků tak lze identifikovat jisté pravidelnosti. Na jejich základě je pak možné rozlišit tři typy uspořádání mocenských vztahů, jež vypovídají o distribuci expertní báze moci ve tř́dě. Tyto tři mody svou povahou odpovídají uspořádáním, o kterých vypovídají dříve realizovaná šetření popisující distribuci moci nejen ve školních třídách, a proto pro jejich označení přejímáme již zavedenou terminologii (viz zejména Jamieson \& Thomas, 1974). Hovoříme tedy o modech kooperace, kompromisu a kompetice, v nichž jsou studenti učitelství svými žáky vnímáni jakožto tzv. rozpoznaní experti, tušení experti či jako experti zpochybňovaní, a to zejména v závislosti na tom, nakolik jsou schopni žákům dopomoci k tomu, aby se oni sami experty stali. Jakých konkrétních kontur jednotlivé mody nabývají, podrobně přiblížíme na následujících stranách.

\subsubsection{Přiznané expertství v modu kooperace}

První mocenské uspořádání mezi studenty učitelství a jejich žáky je charakteristické tím, že studenti učitelství z pohledu žáků disponují dostatečnou poznatkovou základnou a současně jsou s to tyto poznatky žákům vhodným způsobem a s určitou dávkou atraktivity zprostředkovat. Studenti tedy z pohledu žáků splňují to, co se od nich očekává, a v důsledku toho se také žáci do značné míry chovají tak, jak se očekává od nich. Cíle studentů se ocitají v blízkosti cílů žáků (aby předmět zdárně ukončili a aby ve třídě byla alespoň trochu zábava, viz Cothran \& Ennis, 1997, s. 550), čímž dochází ke shodě na definici situace, a mocenské vztahy ve třídě jsou nastaveny v poměrně stabilním modu kooperace.

Jaké podoby za těchto okolností nabývá interakce ve školní třídě, nejlépe dokládá konkrétní prŕíklad - v tomto případě výňatek $\mathrm{z}$ výuky dějepisu studentky Lenky, která žákům popisuje, jak probíhalo sjednocení Německa: 
Ukázka 64

Studentka Lenka, výuka dějepisu, první hodina

U: Prusů bylo více, měli více děl a skončilo to opravdu drtivou porážkou Francie. Tam Francie měla v bitvě zhruba 120 tisíc mužů a $\mathrm{z}$ toho jich bylo okolo 103 tisíc zajato a asi 17 tisíc zabito a Prusové ztratili jenom 9 tisíc mužů, ti jich měli asi 200 tisíc. Takže to bylo opravdu, opravdu jasné. Tak (.) ta bitva u Sedanu, co je to ten Sedan?

ŽŽ: Město.

U: To je město. Vidíte, vidíte ho i na svojí (.) svojí mapě, že jo? Vidíte. Nachází se ve Francii, takže ve městě se opevnil kdo?

K: Francouzi.

U: Francouzi. A zhruba ve čtyři hodiny ráno na ně zaútočili (.) zaútočili ti Prušáci. Když chcete na někoho takhle zaútočit, jak je to lepší? Když jste vy jako...

K: Na koních.

ŽZ̆: ((zasmějíse))

U: Jo, na koních, může být, ale myslím jakoby geograficky.

K: Palbou.

K: Tak na kopci.

U: Na kopci. Takže Prušáci byli na kopci a pálili dolů na to město. Jo? Takže proto ta bitva trvala, ona trvala asi hodinu jenom. Jo? Oni je prostě hnedka, hnedka zmasakrovali.

K: Oni to čekali?

U: Ano, oni to čekali. Oni přijeli, ti Prušáci je- několik dní obléhali v tom Sedanu, takže oni to čekali, ale nemohli nic dělat, protože byli v tom městě.

K: A jo.

U: Jo? Ehm (.) takže tam máme vyhlášeno- jo, tady máte ještě tu kapitulaci, jak na tom obrázku Napoleon III. kapituluje a je tedy zajat.

Studentka Lenka popisuje, jak se uskutečnila bitva u Sedanu. Krom historických fakt přitom zmiňuje i detaily bitvy, jako např́klad čas útoku nebo lokaci obou armád, takže popisovaná historická událost získává pro žáky konkrétní kontury. Studentka v popisu sahá $\mathrm{k}$ emočně zabarvenému slovníku, hovoří o Prušácích, masakrování apod., což může taktéž působit jako prostředek přibližující učivo. Nevyužívá přitom pouze monologický výklad - své promluvy střídá s kontrolními otázkami, jimiž si ověřuje, že žáci její výklad sledují a současně mu rozumí (př́kladem je otázka, co je to Sedan), nebo otázkami, jimiž žáky vede $\mathrm{k}$ tomu, aby si sebe sami představili v popisované situaci (otázkou, jak je nejlepší zaútočit). Uspořádání ve tř́dě žákům dovoluje, aby se zapojili, i když s jistotou nevědí a spíše od boku tipují (jeden z žákủ např́klad navrhuje, že nejlépe se útočí na koních), přičemž studentka jejich nápady přijímá, byt’ sama chtěla slyšet jiné 
řešení. Žáci sami se nebojí pokládat studentce další doplňující otázky a dávají jimi najevo svůj zájem o věc. Mezi studentkou a žáky tak dochází ke shodě na definici situace. Studentce Lence je ze strany žáků připsána expertní moc - disponuje informacemi, o něž žáci mají zájem, a na jejich poptávku reaguje tím, že tyto informace s žáky sdílí, tzn. že vždy na určitou dobu slevuje ze své dominance ve prospěch žáků, jejichž požadavkům ráda vyhovuje, a nechává moc ve třídě cirkulovat od sebe k žákům a zpět (viz kapitola 2.2). Studentka Lenka tak ze své strany splňuje všechny předpoklady pro to, aby si žáci osvojili, co mají, čímž se pro žáky stává tzv. rozpoznaným expertem.

Schopnost zprostřredkovat žákům učivo je jedním z důvodů, proč žáci ve výuce studentů, které považují za experty, dosahují svého cíle - vědí, co mají, a procházejí předmětem bez větších obtíží. V důsledku toho často získávají pozitivní zpětnou vazbu a zažívají pocit úspěchu. To dokládá ukázka $\mathrm{z}$ výuky studentky Mileny:

\section{Ukázka 65}

Studentka Milena, výuka občanské výchovy, druhá hodina

U: Co jste napsali u té první otázky? Co to je životní prostředí? Lukasi?

K Lukas: Všechno kolem nás.

U: Všechno kolem nás. Správně.

U: Sáro, napsalas ještě něco jinačího? Jak- Nebo cos napsala?

K Sára: Ne já jsem tam dávala ty př́íklady, co jsme měli.

U: Jo, taky mohlo být určitě. Tak co napsal Filip.

K Filip: Já jsem tam psal příroda, lidé a všechno co člověk vyrobil.

U: Určitě, to je taky správná odpověd.

U: Tak druhá otázka byla dva klady a dva zápory života ve městě.

Milena žákům ve své první vyučovací hodině vysvětlovala několik málo bodů vztahujících se k životnímu prostředí - nejprve společně vyjmenovávali, co vše může být součástí životního prostředí, Milena pak sdělila žákům stručnou definici životního prostředí, a potom již společně přicházeli na možné výhody a nevýhody života ve městě a na vesnici. $V$ druhé vyučovací hodině, $z$ níž pochází výše uvedená ukázka, žáci písí test, který ověřuje, co si z prredchozí hodiny pamatují. Po jeho odevzdání se studentka žáků ptá, jak odpověděli na testové otázky. Otázky korespondují s tím, jak bylo učivo prezentováno v minulé hodině, a je zřejmé, že žáci odpovědi znají. Lukas, Sára i Filip sice přicházejí každý s jinou definicí životního prostředí, nicméně obsah jejich odpovědí se potkává a žáci od Mileny získávají pozitivní zpětnou vazbu. Opět se vracíme k dosažení shodných cílů - z pohledu žáků je mise studentky úspěšná, nebot jim dopomohla k vlastnímu úspěchu, což byl také cíl, jehož chtěla dosáhnout sama studentka. Platí tedy, že $\mathrm{v}$ okamžiku, kdy studenti dopomohou žákům $\mathrm{k}$ pocitu úspěchu vystavěném 
na tom, že jsou schopni prokázat své vědomosti, stávají se v jejich očích odborníky na své řemeslo. Expertem je pro žáky ten, díky němuž se žáci sami experty stávají. ${ }^{42}$

Bylo by možné předpokládat, že k tomu, aby byl student vnímán jako expert, nejlépe poslouží, když bude s žáky probírat náročnější učivo, v němž se jeho expertnost bude moci naplno projevit. Studenti sami navíc opakovaně zmiňují, že se cítí být experty o to více, o co méně toho jejich žáci vědí, což ilustruje např́íklad citace Zdeny: „Protože jsem si prostě přišla větší odborník v té němčině než v češtině. Tam ty děcka prostě nejsou skoro na žádné úrovni. Prostě pár slovíček že a jako tam si, tam si přijdu jako šéf." $Z$ výsledků dotazníků však vyplývá, že experty se $\mathrm{v}$ žákovských očích mohou stát i studenti, kteří probírají poměrně banální učivo, což se děje zejména ve výuce studentky Mileny:

\section{Ukázka 66}

Studentka Milena, výuka občanské výchovy, osmý ročník, třetí hodina

U: Kam by mohla třeba jet Lucka?

K Pavel: Do Japonska?

U: Do Japonska. A jak bys tam mluvila?

D Lucka: Japonsky.

U: Japonsky, správně. Tak vymysli něco Dominikovi. Nějakou zemi nebo město.

D Lucka: Chorvatsky. Chorvatsko?

U: Chorvatsko. A Dominiku, jak bys tam mluvil?

K Dominik: Chorvatsky.

U: Chorvatsky správně.

Výše uvedená ukázka zachycuje situaci, kdy studentka žáky vyzývá k tomu, at řeknou zemi, do níž by mohli cestovat, a následně uvedou, jakým jazykem by tam mluvili. Žáci v zásadě volí země, jejichž jazyk je odvozen z názvu země, takže se jedná o cvičení, které je kognitivně velmi nenáročné. Učivo, kterému se studentka Milena věnuje, lze přitom považovat za poměrně triviální po celou dobu její praxe. $V$ první hodině s žáky Milena například řeší, po jakých památkách svého města by provedli své prŕbuzné, když by $\mathrm{k}$ nim přijeli na návštěvu, $\mathrm{v}$ následující hodině řeši výhody a nevýhody života ve městě a na vesnici, aniž by nějak revidovala žákovské odpovědi (nevýhodou života ve městě pak dle nich je např́íklad hodně budov či internet), ve třetí hodině spolu s žáky třídí ukázky spisovného a nespisovného jazyka atd. Přesto je právě Milena podle svých žáků největším expertem ze všech sledovaných studentů (žákovské odpovědi vztahující se

42 Žáci se přitom prostřednictvím výuky studentů či učitelů stávají experty, kteří ovládli předdefinované obsahy. Osvojené poznatky jsou žák od žáka analogické a vztahují se ke stejným tématům v podobné míře. $\mathrm{V}$ tomto ohledu tedy výuka směřuje $\mathrm{k}$ tomu, aby se z žáků stali experti unifikovaní a zejména sérioví. 
k expertní bázi moci v jejím př́padě dosáhly průměru 4,89, viz obrázek 9, s. 156, $\mathrm{v}$ důsledku čehož lze říci, že žáci Milenu vnímají jako experta). Je tedy zřejmé, že povaha, resp. náročnost učiva, kterým se tř́da aktuálně zabývá, nehraje výraznou roli, at' už je to dáno tím, že žáci nejsou s to náročnost učiva a tím také nároky kladené na studenta relevantně posoudit, nebo tím, že to pro ně není směrodatné. Co tedy sehrává výraznější roli?

Domníváme se, že jedním z důvodů jsou organizační schopnosti studentů, kterým žáci přičítají expertní moc. Žáci v jejich třídách totiž vědí, co se od nich ve kterém okamžiku očekává, a neocitají se ve stádiu dezorientace, což zvyšuje šance na jejich pozdější úspěch. Příkladem může být ukázka z výuky studentky Mileny:

\section{Ukázka 67}

\section{Studentka Milena, výuka občanské výchovy, první hodina}

U: Vy si tedkka vemte sešit, (1) napíšeme si krátký zápis. Nezapomeňte na dnešní datum, dnes je dvacátého sedmého března. A nadpis bude životní prostředí. (2)

Ž: Do občanské výchovy?

U: Prosím? Do občanské výchovy. (2) Tak datum dvacátého sedmého března (5) a nadpis bude životní prostředí. (15) Tak máte všichni hotovo? Ještě chvilku počkáme. (8) Tak a já vám ted'ka nadiktuju takové dvě větičky krátké (2). Ještě počkáme na Lucku. Všichni máte hotovo? Takže si pište, životní prostř̌edí je vše, co nás obklopuje. Životní prostředí je vše, (.) co nás obklopuje. (2) Životní prostř̌edí je vše, (.) co nás obklopuje. (2) Životní prostředí je vše, (.) co nás obklopuje. Filipe, kde bude čárka v té větě?

K Filip: No není ćárka.

U: Není? Je tam, Klári, čárka?

D Klára: Je před, po vše a po co.

U: Po vše je čárka, tak nezapomeňte, at ji tam všichni máte všichni čárku po vše. Životní prostředí je vše, co nás obklopuje.

Studentka Milena žákům krok za krokem sděluje, co mají dělat, a současně kontroluje, zda se všichni žáci stíhají jejími instrukcemi řídit. Je schopná diktovat tak, že žáci zápisu stačí (což pro řadu jejích kolegů studentů zůstává problémem) a věnuje se i detailům jdoucím mimo vyučovací předmět (jako například interpunkci).

Hladkému průběhu organizace výuky napomáhá také to, že studenti postupují takovým způsobem, jak jsou žáci zvyklí od svých běžných učitelů. Pokud jsou žáci zvyklí na diktování, je pro studenty vhodné, když zápis taktéž diktují. Pokud jsou však žáci zvyklí na zápis na tabuli, stává se diktování problémem. V tomto ohledu se do získané expertní moci studentů promítá spolupráce s cvičným 
učitelem a předcházející hodiny náslechů, kde studenti pronikají do organizačních rutin jednotlivých předmětů. Pokud pak žáci vědí, co mají v kterou chvíli dělat, je pro ně snazší dosáhnout ve výuce úspěchu, a tím tedy opět vnímat jako úspěšného také studenta učitelství, který má na výsledku svůj podíl.

Ve výuce studentů, kterým žáci přiznali expertní moc, lze vysledovat ještě jednu pravidelnost, a tou je jejich důvěra ve znalosti a dovednosti žáků. Studenti žáky povzbuzují v jejich snažení a dávají jim najevo, že věří v úspěch jejich výkonu. To lze doložit např́klad ukázkou z výuky studentky Věry:

\section{Ukázka 68}

Studentka Vẽra, výuka českého jazyka, pátá hodina

U: No? Klári?

D Klára: Ne, já nevím.

U: Proč, vždyt's to říkala správně, tak se neboj.

D Klára: Jaký sjezd? V maskách?

U: Mhm. Takže zase to rozvíjí ten sjezd to v maskách. O jaký sjezd jde? Jde o sjezd v maskách.

Studenti žáky opakovaně vyzývají ke zkoušení odpovědí, a to i v př́ípadě, že si jimi žáci nejsou jistí, jako tomu je u žákyně Klárky v ukázce. Př́padná pochybení se nikterak nepenalizují, takže žákům za cenu malého rizika opět stoupá naděje na úspěch. I v průběhu několika málo hodin je pak znát, že žáci se osmělují a dovolují si se studenty o učivu diskutovat, jako tomu je např́klad ve výuce studentky Lenky:

\section{Ukázka 69}

Studentka Lenka, výuka dějepisu, šestá hodina

K: No tak ale tam nebylo Rakousko.

U: No, tam odmítli pomoct tomu Rusku, tak dejme tomu se jich to týkalo.

K: Ale nebojovali.

U: No, nebojovali, máš pravdu, ale ((směje se)) ale týká se to nás.

Ve chvíli, kdy jsou studenti v průběhu své praxe žáky přijati jakožto rozpoznaní experti, je jim tento status - za podmínky, že jejich výkon zůstává více méně konstantní - připsán po celou dobu praxe a žáci nemají potřebu jejich vystupování zpochybňovat nebo proti němu určitým způsobem revoltovat. Přiznané expertství studentům není odebráno dokonce ani ve chvíli, kdy se role ve tř́ídě otočí a studenti se epizodicky stanou těmi, kdo chybují, což dokládá situace Z výuky studentky Lenky (zůstáváme přitom ve výuce dějepisu): 


\section{Ukázka 70}

D: Co jsme měli zakroužkovat?

U: Jo, habsburská monarchie, c, c. Promiň, já jsem Ti nerozuměla.

D: To nevadí.

Důsledkem tohoto uspořádání pak je to, že studenti se v rámci své několikahodinové praxe osmělují, experimentují s výukovými metodami a rozšiřují si jejich repertoár. Ve výuce např́klad narůstá zastoupení skupinové práce, žáci sami mohou vést výklad, zvyšuje se celkový podíl žákovských promluv. Praxe tak splňuje účel, který od nich studenti očekávají a který popisuje např́klad Milena: „Potřebuju mnohem delší praxi, abych si tak nějak, měla nějaký seznam těch svých triků, které bych věděla, že vždycky zafungují." Lze tedy říci, že v modu kooperace, který lze chápat jako modus ideální, praxe splňuje svůj cíl, nebở studenti se v jejím průběhu učí vyučovat.

\subsubsection{Tušené expertství v modu kompromisu}

Druhý typ mocenských vztahů, které jsou ustaveny na míre percipovaného expertství zúčastněných stran, lze taktéž chápat jako konsensuální uspořádání, kdy dochází k udržení funkčního učebního prostř̌edí. Ani v tomto případě se tak školní třída neproměňuje v bitevní pole, kde se dvě protichůdné strany snaží prosadit své zájmy. Přesto je mezi kooperací a kompromisem patrný rozdíl. Ten pramení zejména $\mathrm{z}$ toho, že výuka se $\mathrm{v}$ tomto př́padě odehrává bez angažovaného nasazení zúčastněných stran, které jsme $\mathrm{v}$ modu kooperace mohli sledovat $\mathrm{v}$ orientaci na žáky ze strany studentů i v aktivní a mnohdy spontánní participaci žáků.

Jakou podobu má interakce v modu kompromisu, zachycuje ukázka z výuky studenta Radka, který žákům vysvětluje, co se skrývá pod pojmy vid dokonavý a vid nedokonavý:

\section{Ukázka 71}

\section{Student Radek, výuka českého jazyka, druhá hodina}

U: Takže vyjadřují budoucí čas, teda prrítomné tvary vyjadřují budoucí čas. Z toho nám vyplývá ((napiše šipku na tabuli)), že slovesa dokonavá nedokáží vytvořit přítomný čas. Tak (.) přítomné tvary vyjadřují budoucí čas. (několikrát opakuje). Nemohou vytvořit př́itomný čas. A přítomné tvary vyjadřují budoucí čas. Je to jasné? Ted’ si to ukážeme na př́kladu. ((podívá se do svých poznámek)) Tak. (5) Máme sloveso. (1) Ještě to řekneme tak. Tys Tome ř́kal ((otočí se směrem $k$ Tomovi a ukáže na něj fixou)), jak se tvoří.

K Tomáš: Pomocí předpony.

U: Tak tvoříme je pomocí předpon. Pomocí předpon, jo? Tak další odrážka. 
((zapiše ji na tabuli)) Od sloves nedokonavých se tvoří pomocí předpon. ((na tabuli za odrážku píš predpony)) Od sloves nedokonavých se tvoří pomocí předpon ((divá se do poznámek)), (3) která ovšem na rozdíl, které ovšem na rozdíl od sloves nedokonavých mění význam slovesa. Takže od sloves nedokonavých se tvoří pomocí předpon, která mění význam slovesa. Jako prríklad ((napiše na tabuli psát)) (4) psát. ((poodstoupi od tabule)) Je sloveso dokonavé nebo nedokonavé? D Maruška: Dokonavé.

K Tom: Nedokonavé.

U: Tak. Od sloves nedokonavých se tvoří pomocí předpon. To znamená, že tady máme sloveso nedokonavé.

Radkův výklad netrpí tím, že sám Radek by učivu nerozuměl, jeho znalost obsahu je z jeho výuky patrná. Slabinou však zůstává didaktická znalost obsahu - Radek se opírá o abstraktní definice, staví na znalosti dalších gramatických pojmů, učivo po dlouhou dobu nepropojuje s konkrétními jazykovými manifestacemi v podobě př́kladů a monologicky je vysvětluje ve dlouhých blocích. Jako v př́padě Radka, je také pro další studenty, které svoji praxi uskutečňují v modu konsensu, typické, že ačkoli zpravidla disponují potřebnými znalostmi, problematické je pro ně samotné zprostředkování učiva. Práce s poutavostí výkladu (v podobě kompozice znalostí spolu s žáky, propojování učiva s každodenním životem, nebo za pomoci emočně zabarvené slovní zásoby, k nimž se uchylují studenti v modu kooperace) je prozatím pro studenty velkým tématem do budoucna.

Důvod, proč tomu tak je, vysvětluje v rozhovoru např́iklad Zdena: „Přijdu jakoby na tu základku a mám vysvětlovat třeba šestákům nějakou primitivní látku. Co to tenkrát bylo, kdy se piše, píše dlouhé $i$. Třeba naší učitelce. Jo, že tam je dlouhé $i$ a třeba a viděli jsme naši učitelku, tam je krátké. A ted’ já jim to mám vysvětlit a naučit je to. A jakoby já todlecto nevím. Já todlecto nevím. Já třeba vím, že proč to je, že je to čtvrtej pád a proto je to takhle a takhle. Nebo je to sedmej pád a proto je to takhle a takhle. Ale já už nevím, třeba že prostě těm děckám je potřeba říct, že si musí pomoct tím zájmenem ten jo. (...) Takže eee třeba na fakultě na nás do nás tlučou takovýhle info, jakoby informace, abychom věděli celou prŕruční mluvnici češtiny. Když teda tedka mluvím o češtině a podobně, ale už jakoby nejsme připraveni na to, jak to předat těm třeba šestákům. Kterejm to musím předat polopatě, jo? Já bych jim třeba řekla dvacet pouček, ale jako ty jim říct nemůžu, protože by na mě koukali jak tele na nový vrata." Je zřejmé, že Zdena své znalosti nezpochybňuje. Sama je toho názoru, že teoretických pouček, které se k učivu vztahují, zná víc než dost. To jí však nepomůže v tom, jak učivo srozumitelně vysvětlit žákům.

Vratme se k cílům, které na učební situace kladou studenti i žáci. Zatímco studenti chtějí své žáky něco naučit, žáci chtějí předmětem zdárně projít - jejich cíle se tedy v tomto ohledu protínají. Také v modu kompromisu se obě strany 
v tomto cíli potkávají, nicméně ve snaze o jeho dosažení je zde nutné značné úsilí z obou stran. Zatímco studenti zkoušejí, jak žákům učivo zprostředkovat, žáci jejich snahu nikterak nepodrývají a expertnost studentů nezpochybňují. Praxe studentů, kteří se s žáky ocitají v modu kompromisu, se tedy nese ve znamení hledání cesty $\mathrm{k}$ tomu, jak žákům zprostředkovat učební obsah. Promítá se však tento deficit do toho, nakolik studenti podle žáků disponují expertní mocí?

Pokud studenti viditelně nechybují, nejsou žáci zpravidla s to relevantně posoudit, kolik toho studenti o učivu vědí. Také $\mathrm{v}$ př́padě Zdeny a Radka proto žáci předpokládají, že oba studenti se v učivu orientují, byt je místy nejsou schopni „přeložit" tak, aby mu žáci snadno porozuměli. Zdenu i Radka tak lze z pohledu žáků chápat jako tušené experty, nebot jim žáci z velké míry přiznávají expertní moc (byt je jejich skóre malinko nižší než u kolegů z modu kooperace - Radek i Zdena disponují hodnotou $\bar{x}=4,3$, viz obrázek 6, s. 64).

Obtížně vstřebatelné zprostředkování učiva ze strany studentů se automaticky promítá také do jednání žáků. Zatímco $\mathrm{v}$ předchozím modu jsme mohli sledovat, jak žáci sami aktivně vstupují do komunikace se studenty, chtějí odpovídat, kladou otázky a komentují učivo, v uspořádání konsensu jejich angažované nasazení pro věc absentuje. Dủvod dle našeho názoru spočívá $\mathrm{v}$ tom, že pokud si žáci v závislosti na obtížněji srozumitelném výkladu studentů - nejsou svými znalostmi jistí, nechtějí jít $s$ kůží na trh a dávat najevo své neporozumění. Jak jsme již uvedli, pro žáky je důležité zažívat pocit úspěchu založený na tom, že disponují dostatečnou poznatkovou základnou a stávají se pro studenty komunikačními partnery, kteří s nimi dovedou držet krok. $\mathrm{V}$ důsledku obtížně vstřebatelného zprostřredkování učiva je však v tomto modu žákovský úspěch oddálen, nebot žákům trvá, než dosáhnou cíle v podobě ovládnutí učiva do té jimi požadované míry. Žáci tak hovoří zejména tehdy, když jsou k tomu studentem vybídnuti.

$\mathrm{Na}$ jejich odpovědi, které př́ípadně nejsou správné, navíc studenti nereagují zpětnou vazbou, v níž žákům nepomáhají, aby ke správnému řešení došli, ale spíše své otázky přesměrují na jiného z žáků, jako tomu je například v ukázce $\mathrm{z}$ výuky Zdeny:

\section{Ukázka 72}

Studentka Zdena, výuka českého jazyka, třetí hodina

U: Další. Tadeáš?

K Tadeáš: (nnn) Bude měkký I.

U: Nebude. Co jsme si tedkka říkali na začátku při. Nebo na začátku. Než jsme začali dělat cvičení? (.) Tak jsme si opakovali poučky. (.) O jaký se jedná pád? U: ((směrem k žákyni Lucce)) Tak porad’.

D Lucka: Sedmý pád.

U: O sedmý pád. Výborně. 
Tadeáš, který chybuje při určení tvrdého či měkkého $i$ v koncovce př́idavného jména, se od Zdeny dozvídá, že jeho odpověd není správná. Ve snaze o odůvodnění jevu se však studentka záhy obrací na Tadeášovu spolužačku, místo aby žákovi pomohla, jak má ke správné odpovědi dojít sám. Zpětná vazba, kterou žáci ke svým odpovědím dostanou v prrípadě pochybení, je tak nemotivuje, aby odpovídali, pokud si učivem nejsou jistí. Odlišná je situace až ve chvíli, kdy žáci správné odpovědi znají. Tehdy se ve snaze o získání pozitivní zpětné vazby snaží dostat ke slovu, jako tomu je v modu kooperace.

Co studentům v tomto modu nicméně nelze upřít, je jejich schopnost organizace výuky, nebot žáci v jejich třídách vědí, co se od nich očekává a jak mají aktuálně jednat (ve stejném duchu se žáci také vyjadřují v dotazníkových položkách). Po této stránce si tak studenti z modu kompromisu nijak nezadají se svými kolegy z modu kooperace. Jak jsme uvedli, ve třídách často absentují angažovaní řečníci z řad žáků. Studenti proto tuto situaci řeší tím, že se zaměřují na to, aby mohli monitorovat žákovskou práci. Systematicky vyvolávají všechny žáky, čímž zjištují, nakolik žáci učivu rozumějí, podle toho přizpůsobují svůj další výklad. Zároveň tak minimalizují žákovské únikové chování v podobě věnování se jiným než výukovým činnostem. Nedostatky plynoucí ze zprostředkování učiva jsou tedy v tomto ohledu kompenzovány tím, že studenti dobře zvládají organizovat výuku a zapojovat žáky, čímž je nutí $\mathrm{k}$ tomu, aby s učivem pracovali a hledali si cestu, jak mu porozumět.

$\mathrm{V}$ modu kooperace jsme hovořili o tom, že studenti, které lze označit jako rozpoznané experty, rozšiřují repertoár výukových metod a zkoušejí svou výuku různě inovovat, jejich záběr se tedy rozšiřuje. U studentů, které lze ze strany žáků označit spiše jako tušené experty, k rozšiřování inventáře výukových metod nedochází. Studenti naopak setrvávají u rutinních postupů, k nimž se uchýlili od začátku své praxe, a pokoušejí se tyto metody propracovat. Zatímco u rozpoznaných expertů dochází k rozšiřování inventáře výukových postupů a metod, zde dochází k prohloubení jeho základních složek.

\subsubsection{Zpochybněné expertství v modu kompetice}

Uspořádáním, které doplňuje triádu, z níž jsme zatím představili mody kooperace a kompromisu, označujeme jako modus kompetice. Jak jeho název napovídá, jedná se o uspořádání, ve kterém se studenti učitelství a žáci snaží na úkor druhé zúčastněné strany prosadit své zájmy. Definice situace je rozdílná a ve třídě se objevují otevřené konfliktní situace.

Již jsme uvedli, že žáci přiznávají expertní moc tomu, díky jehož expertnosti se snáze (jako tomu je u modu kooperace) či obtížněji (jako v modu konsensu) sami experty stávají. V modu kompetice se tedy ocitají studenti, kteří žákům podle jejich názoru $\mathrm{k}$ úspěchu dopomoci nemohou, nebot’ sami expertnosti nedosahují. Hodnocení, která žáci studentům připsali prostřednictvím svých 
odpovědí v dotazníku, ani v tomto př́ípadě rozhodně nejsou alarmující. Studentka Karla skončila s výsledkem $\bar{x}=4,08$ jen o něco málo hůř než její kolegové, o nichž jsme hovořili jako o tušených expertech, Petra se u žáků dostala na hodnotu průměru 3,67 a nejnižší průměr měla Alice s výsledkem 2,95, čímž se její hodnocení velmi těsně ocitlo na negativní straně škály. Interakce ve třídě však přesto nabývá odlišných kontur. Mocenské vztahy mezi studenty a žáky jsou charakteristické opakovanou snahou žákủ o revoltu, na niž studenti reagují snahou udržet dění ve třídě pokud možno v chodu. Proto v tomto modu přichází ke slovu donucovací moc. Patrné je to právě u studentky Alice, které žáci připsali nejvyšší hodnotu legitimní/donucovací moci ze studentů v našem výzkumném vzorku (podrobněji viz kapitola donucovací moc). V tomto př́ípadě tedy s ohledem na studenty můžeme hovořit o expertství zpochybňovaném. Jaké důvody $\mathrm{k}$ tomuto uspořádání vedou?

Zpochybnění expertního statusu může $\mathrm{v}$ první řadě vycházet $\mathrm{z}$ nepřesvědčivého výkonu studentů, jako tomu je u studentek Petry nebo Karly:

\section{Ukázka 73}

\section{Studentka Karla, výuka dějepisu, první hodina}

K: Co si k tomu Lašutovi máme napsat? (jedná se o Lájosze Kossutha - poz. výzkumníka)

U: Ústřední postava v povstání. (1) Anebo taky nic. Paní učitelka říkala, že to po vás nebude chtít, že je to dost složité. Na střední to určitě budete probírat víc a možná i trochu něco jiného. Takže já to napíšu nahoru.

K Roman: ((něčemu se sám pro sebe zasměje))

DD: ((v prostřední lavici se spolu tiše baví))

U: Tak, půjdeme dál (4). ((dívá se do svých poznámek)) Jelikož se samozřejmě, jelikož císař zběhl zbaběle do Insbrucku při povstání ve Vídni, tak (2) Madaři prohlásili Habsburky jako sesazené z trůnu. (3) A vlastně, já se omlouvám, jsem to řekla špatně.

K: Ach jo!

U: Nicméně, důsledek byl stejný - císařem byl František Josef I. A, jak jsme si říkali u Itálie, že Karel Albert napadá Habsburské země, tak František Josef I. jde zasahovat do Itálie, tím pádem opouští rakouské země a Madaři mají navrch a prohlásili Habsburky, prohlásí Habsburky jako sesazené z trůnu.

Karla žákům vysvětluje učivo revoluce v Uhrách. Její odpověd’ na žákovskou otázku, co si zapsat k ústř̌ední postavě povstání, zachycuje distinktivní rys výkladu studentů v modu kompetice, a to je zpochybnění významu předkládaného učiva. Studentky Petra i Karla žákům opakovaně sdělují, že učivo, které vysvětlují, není důležité, učitelka se na ně žáků nebude ptát atd. Karla v ukázce například žákům sděluje, že si učivo nemusejí zapisovat a že je podle učitelky, kterou žáci 
na dějepis běžně mají, příliš složité. Učivo tak ze strany žáků ztrácí na významu nijak totiž nepřispěje $\mathrm{k}$ úspěšnému ukončení předmětu.

Ukázka zaznamenává ještě jeden rys charakteristický pro výklad studentů v modu kompetice. Uvedli jsme, že žáci nejsou schopni relevantně posoudit, jaká je reálná poznatková základna studentů, kteří u nich realizují praxi. I ve chvíli, kdy studenti chybují, to totiž žáci nemusejí rozpoznat (studentka Petra žákům např́klad opakovaně opravuje předponu v sousloví strávit oběd na z-trávit oběd, aniž by byla upozorněna na své pochybení). Chyby, jichž se studenti v modu konfliktu dopouštějí, jsou však pro žáky často viditelné. Studentka Karla v ukázce např́iklad žákům sděluje, že chybovala, ale svou předchozí chybu přitom nijak nereviduje. To pak v očích žáků pochopitelně zpochybňuje erudici studentů.

Ve snaze o snížení množství chyb či eliminaci nevědomosti je pro modus kompetice typické, že studenti vracejí žákovské otázky zpět na žáky. Ve chvíli, kdy žáci kladou studentům otázky (často ve snaze o testování jejich znalostí), reagují studenti (na rozdíl od kolegů v přecházejících modech) převedením otázky zpět na žáky, a to zpravidla $\mathrm{v}$ podobě domácího úkolu. $\mathrm{O}$ této své strategii zpětně hovoří např́iklad Karla: „Pokud jsem něco nevěděla, tak jsem určitě odehrála stylem, do příště si to zjistí sám a do př́ště mají za úkol všichni to zjistit. Já bych si to do pŕíště taky zjistila a mohli bychom to zkonzultovat.“

Jiný důvod pro ustavení modu kompetice lze hledat ve výuce studentky Alice. V jejím př́padě by se dalo říci, že se své expertnosti dobrovolně vzdává. Úlohy, které žákům dává, totiž mají v zásadě otevřená zadání, a studentka Alice žákům opakovaně sděluje, že jejich odpovědi a řešení jsou minimálně stejně dobré jako její vlastní. To zachycuje níže uvedená ukázka z hodiny občanské výchovy, v níž studentka vede žáky $\mathrm{k}$ tomu, aby výroky formulované agresivně upravili tak, aby byly formulované asertivně:

\section{Ukázka 74}

Studentka Alice, výuka občanské výchovy, třetí hodina

U: Tak, když máme: Tvoje vystupování je neotesané. (3) Co byste řekli trochu jinak. Tvoje vystupování je neotesané.

DD: Tvoje vystupování se mi nelíbí.

U: Dobře, holky? ((obrátí se k dívkám v první lavici u svého stolu))

D: Nevystupuješ dobře, si myslím.

U: Nebo třeba věta: myslím, že by ses mohl chovat lépe. Mohlo by být? $(($ šum $))$

D Kristýna: Jde o to, jaké vystoupení jako v divadle nebo vystoupení, jak se chová.

U: Ale tam není napsáno vystoupení, ale vystupování. To je to, jak se chováš.

D Kristýna: A to nemůže bejt vystupování jako v divadle. Ale to je jenom můj názor. 
U: ((přejde ke stolu)) Tak a podíváme se na poslední větu: Nezírej na mě.

D: Tvůj pohled se mi nelíbí.

K David: Moc se mi nelíbí, jak se na mě díváš.

U: Dobře. (1) Výborně. (1) Můžu tě poprosit, aby ses na mě přestal dívat?

D Andrea: To bych neřekla.

K David: Můžu tě poprosit...

U: Neřekla? Ani třeba cizímu člověku? (1) Ne? (2) A vzadu ještě?

Alice nejprve počká na dvě odpovědi od žáků, které schválí jako možné, a poté nabízí své vlastní řešení. Na tomto místě se komunikační struktura, kterou studenti učitelství (tím, že uzavírají jednotlivé interakce, a mohou tak hodnotit, co se od žáků dozvěděli) za běžných okolností mohou využít pro svůj prospěch, zcela otočí, a studentka naopak nechává žáky hodnotit její řešení. Žákyně Kristýna reaguje tím, že (chybně) poukazuje na dvojí výklad zadání, čímž zároveň dává najevo, že studentčina odpověd' nemusí být správná. Alice se snaží Kristýně vysvětlit, že zadání lze chápat pouze jedním způsobem, nicméně žákyně s ní nadále nesouhlasí. Totéž se opakuje i v následující interakci, kde žáci asertivně formulují další větu. Také v tomto prípadě studentka přichází s vlastním řešením, které žáci otevřeně zamítnou. Na studentčinu snahu, za jakých okolností by bylo možné její výrok použít, již dále nereagují a nechávají její otázku bez odezvy. Žáci se tedy řídí logikou, že když sami vědí lépe než studentka, není jim ve výuce ku prospěchu. Alice se v důsledku svého liberálního př́stupu ocitá ve stejné situaci jako Petra a Karla.

Nejedná se nicméně o jediný důvod, proč se uspořádání vztahů ve třídě na bázi expertní moci ocitá v modu kompetice. Všechny důvody, které jsme doposud uvedli u jednotlivých modů, spočívaly v aktivním jednání studentů, a hypoteticky tedy bylo $\mathrm{v}$ jejich silách uspořádání ve třídě proměnit. U studentek Alice a Karly (Petra je na tom pouze o něco málo lépe) však hraje výraznou roli také to, že se s nimi žáci neidentifikují a přisuzují jim negativní moc referenční, která s mocí expertní výrazně souvisí (viz kapitola 4.6). Čím méně tedy žáci studenty vnímají jako někoho, kdo je jim blízký, s kým mají hodně společného a komu by se potenciálně chtěli podobat, tím méně budou podle žáků také odborníky ve svém oboru.

Ve shodě s definicí moci jakožto vztahové proměnné se zpochybňování expertnosti studentů ze strany žáků výrazně promítá do toho, jak studenti dále jednají. Čím více žáci o expertnosti studentů pochybují, tím více studenti usilují o to, aby žákům dokázali, že toho vědí více než oni. $V$ důsledku této soutěže kdo z koho jsou to právě vyučovací hodiny v modu kompetice, kde studenti často žáky testují na sadě výjimek či chytáků, což dokládá například diktát u studentky Petry: 


\section{Ukázka 75}

Studentka Petra, výuka českého jazyka, třetí hodina

U: Tamější obyvatelé, čárka. (3) Strávit oběd.

K: Jak?

U: Strávit oběd. (10) Strávit oběd, čárka. Stěží. (4) Stěží.

K Adam: Jenom?

U: Stěží jenom.

K Vojta: Strávit oběd stěží?

U: Prosím?

K Vojta: Strávit oběd stěží?

U: Strávit oběd, čárka, stěží, čárka. ((naznačuje čárky gestem)) Vyviklaný zub. K Honza: Ještě jednou.

Studenti se ve snaze o získání a udržení expertního statusu uchylují k postupům, kdy žáky zkoušejí na nejproblematičtější složky učiva, u nichž stoupá šance, že žáci budou chybovat, a studenti tak budou moci dokázat, že se od nich žáci mají co naučit. Ze strany žáků je tento postup pochopitelně přijat kriticky, čímž se míra konfliktů ve tř́dě dále stupňuje.

Žáci pak na výkon studentů reagují třemi způsoby. V první řadě se studenty zkrátka nekomunikují, jako tomu je např́íklad u Alice:

Ukázka 76

Studentka Alice, výuka občanské výchovy, třetí hodina

U: Dokážete bez problémů uznat, že někdo měl pravdu a vy jste pochybili?

(.) Dokážete někoho pochválit, když se vám to třeba úplně (.) nelíbí? ((trochu gestikuluje))

U: No?

(7)

U: Nebudeme spolu komunikovat? ((vrací se za učitelský stůl))

U: Tak jo (.) Otevřete si prosim vás učebnice na straně 36.

V druhé řadě dávají studentům najevo, že nemají zájem na tom si nabízené učivo osvojit. Zatímco $\mathrm{v}$ předchozích modech se snaží dosáhnout úspěchu a učivo ovládnout, zde naopak triumfují tím, že učivo, které jim studenti zprostředkovávají, odmítají. Ve výuce studentky Petry se žáci např́ílad trumfují v tom, kdo má horší známku, a dávají studentce najevo, že jim na výsledné známce nezáleží: 


\section{Ukázka 77}

Studentka Petra, výuka českého jazyka, třetí hodina

D Ivana: Máme si to napsat do žákovský?

U: Ted' to chci říct, nechte mě mluvit.

K: Paní učitelko, dostal někdo vůbec jedničku?

K: Bára dostala jedničku.

U: Aspoň umí jediná $\mathrm{z}$ vás pravopis. Půlka třídy měla pětky.

K Samir: Jenže pětka je jednička u někoho.

U: Po některých jsem to nemohla ani přečíst.

Do třetice pak žáci studentům více či méně otevřeně naznačují, že si ve své činnosti nevedou dobře. Poukazují na to, že student špatně diktuje, jako tomu je výše, nemá vhodně připravený zápis, chybuje v učivu, má naplánované činnosti, které jsou podle žáků (a ne vždy neopodstatněně) zcela bez užitku, nebo má špatně připravené zadání, jako tomu je například u Alice:

\section{Ukázka 78}

Studentka Alice, výuka občanské výchovy, čtvrtá hodina

U: Tak a máme tam poslední ještě. To byste mohli. Možná jste to zažili. Jak byste odmítli spolužačku, se kterou se nijak zvlášt nekamarádíš, a ona chce půjčit tvůj discman, který stř̌ežís jako oko v hlavě a nikomu ho nepůjčuješ?

ŽŽ: Discman? Discman? Cože?

U: Tak převedte to na dnešní dobu a chce půjčit třeba váš mobil. Takže jak byste odmítli takovou spolužačku?

ŽŽ: ((šum))

U: A posloucháme všichni prosím.

D: Že ne.

U: Jenom bys řekla ne. Bez vysvětlení? Ehm. Tak kdo by řekl něco jiného?

K: Ne, nikomu to nepůjčuji.

K Kuba: Záleží, kdo by to byl.

U: No vždyt to máš napsané. Spolužačku, se kterou se nijak zvlášt̉ nekamarádíš.

D Klára: Tak když se s ním nijak nebavím, tak pochybuju, že by ten člověk za mnou došel sám, že si to chce něco půjčit.

U: Takže bys taky řekla jenom ne.

D Klára: $\mathrm{Ne}(\mathrm{N})$.

U: Tak a neřekl byste někdo třeba. Neřekli byste např́klad, nezlob se, já ten mobil nikomu nepůjčuju, takže ho nepůjčím ani tobě?

D: Ne. Ne. Ne, protože bych ho pak třeba začla někomu půjčovat a ona by si toho mohla všimnout.

U: Tak otočte si všichni stránku a tam máme ještě poslední dva případy. 
Alice s žáky na modelových situacích trénuje, jak asertivně říci ne. Žáci však nejprve poukazují na to, že modelová situace se může týkat studentky, ovšem jich ne (opakováním slova discman poukazují, že zadání je z jiné doby než oni), Kuba pak z možné nepozornosti reaguje tím, že zadání je neúplné, a krátce poté se téhož chytá i žákyně Klára s tím, že zadání není reálné. Studentka proto situaci řeší tím, že sama nabízí řešení situace. Žáci je však s oporou o validní argument odmítají.

Podobné situace se odehrávají také u studentky Karly. Ta např́ílad dává žákům za úkol rozdělit požadavky na státoprávní a liberální, aniž by jim vysvětlila, co který z pojmů znamená. Žáci proto proti úkolu otevřeně revoltují a dávají najevo, že se míjí účinkem. Studentka navíc žákům opět sděluje, že se toto učivo nebude testovat, čímž žákovské opozici dává do ruky o argument víc, proč je plnění úkolu zbytečné:

\section{Ukázka 79}

Studentka Karla, výuka dějepisu, první hodina

U: Všech těch 12 požadavků rozdělit, jestli je to státoprávní, jestli je to liberální.

K Petr: Paní učitelko, to uděláme spolu, stejně tomu nikdo nerozumí.

U: Společně si to potom zkontrolujeme.

D: [(nnn)]

ŽŽ: ((pracují, hledí převážně do učebnic a sešitů nebo jeden na druhého))

K Petr: (nnn) národnostní?

U: No tak národnostní.

K4: Jak to mám jako vědět?

U: ((na K4, u jeho lavice)) Možná je jich tam víc, musíš si to přečíst, abys to věděl. ((odchází od něj, obchází dalši lavice a ptá se)) Kolik toho máte?

K4: Hmm Tak to stejně nebudu vědět.

K Petr: Jak to mám jako poznat?

ŽŽ: ((pracovní hluk, polohlasné rozhovory, dotazy))

(...)

U: Bud' to opíšete celé, nebo to dokážete zestručnit.

K Petr: To se nedá, přece. To je úkol, co se nedá.

U: Zestručnit - na střední budete muset taky umět zestručňovat.

ŽŽ: Jenomže- [Jenže] Jenomže jsme na základní škole.

K: Když já nevim, co je to to státoprávní, národnostní.

K4: Ale paní učitelko.

U: A navíc jsem říkala, že test $\mathrm{z}$ toho nebude.

K4: Ježišmarjá, tak proč to děláme?

U: Abyste cvičili svoje schopnosti.

K4: Já už je mám tak vycvičený, (1) že už to ani není možný. 
Studenti v modu kompetice navíc svou pozici oslabují také tím, že - na rozdíl od svých kolegů v předchozích modech - nedisponují organizačními schopnostmi a nenavazují na rutiny, které žáci znají od svých běžných učitelů. To může doložit krátká ukázka $\mathrm{z}$ hodiny literatury studentky Petry, kdy mají žáci přednášet referáty:

\section{Ukázka 80}

\section{Studentka Petra, výuka českého jazyka a literatury, pátá hodina}

U: Tak se rozhodněte, kdo půjde.

K Marek: Máte to v kalendáŕi.

\section{ŽŽ: ((žáci se dohadují))}

Žáci, kteří nemají zájem dosáhnout se studenty určité formy kompromisu, tedy využívají př́ležitostí, kterých se jim v tomto uspořádání hojně dostává, aby mohli zpochybnit znalosti studentů i jejich didaktické či organizační schopnosti a dovednosti. Tyto postupy navíc místy využívají rádoby ve shodě s tím, jak by se ve výuce správně měli chovat, čímž oslabují možné protireakce ze strany studentů. O této zkušenosti hovoří např́klad Petra: „Byl trochu problém udržet vlastně kázeň nebo pozornost $\mathrm{v}$ té tř́́dě. Trochu je to možná patrné i $\mathrm{z}$ té nahrávky, že ta třída fungovala tak trochu jako celek, jako skupina, kdy když někdo přednesl referát, tak oni dlouho tleskali, nebylo to možný utišit a tak dál.“ Stejný zážitek zprostř̌edkovává také výuka studentky Alice, v níž se žáci baví, nicméně ve chvíli, kdy se studentka napomene, se ohrazují, že se baví o učivu. $V$ tomto případě hovořit o žákovské kolonizaci (viz kapitola 2.2), kdy žáci využívají běžných školních norem s cílem splnit své cíle, odlišné od cílů studentů.

$\mathrm{V}$ modu kooperace jsme hovořili o tom, že studenti na situaci ve tř́dě reagují rozšiřováním inventáře výukových metod a postupů, v modu konsensu prohlubováním metod a postupů stávajících. U studentů $\mathrm{v}$ modu kompetice naopak můžeme hovořit o určité stagnaci, kterou zmiňují také sami studenti. Např́klad Petra ř́ká: „Já už jsem tu poslední hodinu brala prostě, at to mám za sebou. Poslední hodinu už jsem to nějak vzdala, takže jsem se už nějak extrémně nesnažila, nic." Studentka Karla řešila svou výuku v posledních hodinách praxe tím, že studentům pouštěla audiostopy Toulek českou minulostí a sama již krom ovládání techniky participovala co nejméně. Cíl studentů tedy v tomto případě nespočívá ve zdokonalení či rozšíření aktuálních dovedností, ale lze jej jednoduše shrnout jako snaha přežít.

Při ohlédnutí za svou praxí studenti v modu kompetice o žácích hovoří s despektem a bez velkého očekávání. Například Karla uvádí: „Ti žáci to zkouší. Proč mít obalenej sešit. Proč vyhazovat támhle, když si za to může koupit pytlík brambůrků, že.“ Podobně Petra o žácích říká: „Nespolupracují, že, pořád řvou, baví se, jsou jak zvíŕátka.“ Z rozhovorů se studentkami ovšem nevyplývá, že by je 
stávající zkušenost nějak odradila. Pro situaci ve tř́ílě totiž mají vysvětlení. Petra např́klad ř́ká: „Každopádně podle všech jsem dostala nejhorší třídu na škole ((pousměje se)), takže to bylo celkem takový ... Všichni se divili, že na začátek zrovna, když jsem ještě nikoho nikdy neučila, tak že mi dali zrovna tady tu tř́ídu." Studentka Karla oproti tomu hovoří o nedostatečném čase, který měla na přípravu: „Tu královnu Viktorii jsem si teda musela nastudovat úplně. Jsem jezdila po internetu, v učebnicích, všude možně, kde o ní byly kde jaké zmínky. A zas na druhou stranu nešvar internetu, že většina věci je na wikipedii a jiné zdroje moc nejsou. Ve chvíli, kdy se to dozvíte, že druhej den máte učit zrovna todle, tak nemáte moc čas lítat po knihovnách, nastudovávat dvousetstránkové knížky o někom. Pokud je vůbec seženete, protože jsou třeba vypůjčené. Takže jsem byla ráda, že aspoň do nějaké míry jsem to zvládla nastudovat." U studentky Alice přichází s důvodem sama cvičná učitelka: „To je strašně, strašně těžké téma.“ Karla uvádí jako důvod také to, že cvičná učitelka, která měla mít studentku na starost, onemocněla, a studentka tak zůstala ve výuce sama jakožto suplující učitel: „Jak tam paní učitelka nebyla, tak jsem nevěděla vůbec, co s nima mám dělat. Že mě nenechala žádné instrukce, nic, takže jsem vůbec netušila, co s nima mám dělat. Takže to, co jsem s nima dělala, tak jsem si to jakoby vymýšlela sama, co by se tak mohlo." Vytvářet hypotézy o tom, nakolik by přítomnost a kvalitnější instrukce cvičných učitelek ve výuce zvrátila uspořádání ve třídě, pochopitelně není možné (cvičný učitel navíc chyběl tř̌eba také ve výuce studenta Radka). Nutné je však poznamenat, že cviční učitelé chyběli vždy nejméně v druhé půli vyučovacích hodin všech studentek, jejichž výuka skončila v modu kompetice.

\subsubsection{Shrnutí: Experti? Zatím ještě ne}

Ukázali jsme, že mocenské vztahy ve třídách studentů učitelství se mohou pohybovat ve třech modech. V modu kooperace se studenti učitelství a jejich žáci shodují na definici situace, ve tř́iě dochází k aktivní participaci obou stran a spolu s tím také k cirkulaci moci po třídě. Studenti učitelství jsou svými žáky rozpoznáni jakožto experti. Také v modu kompromisu je studentům přiznán status expertů, nicméně se jedná o expertství tušené. Studenti v tomto modu totiž disponují oborovými znalostmi, ale nalezení způsobu jejich didaktického zpracování pro ně doposud zůstává náročné. $V$ posledním modu označeném jako kompetice je naopak expertství studentů učitelství v důsledku jejich opakovaného pochybení, způsobu zprostředkování učiva i organizačního uspořádání žáky spíše zpochybňováno. Ve všech třech modech přitom sehrává významnou roli to, nakolik jsou studenti učitelství s to dopomoci žákům k tomu, aby se sami stali experty a zažili ve školní třídě úspěch. $V$ modech kooperace i kompromisu se žákům daří dřive či později úspěchu dosáhnout, zatímco v modu kompetice je dosažení úspěchu ztíženo a oddáleno. Bez ohledu na to, zda se studenti se svými žáky ocitají v modu 
kooperace či kompetice, nicméně platí, že expertní moc, kterou žáci studentům připisují, se pohybuje nejhủře těsně pod středovými hodnotami, jimiž se žáci vyjadřují v tom smyslu, že nelze říci, zda student expertem je, či není. Většinou však jejich hodnocení bývá pozitivnější, což zachycuje obrázek 9 .

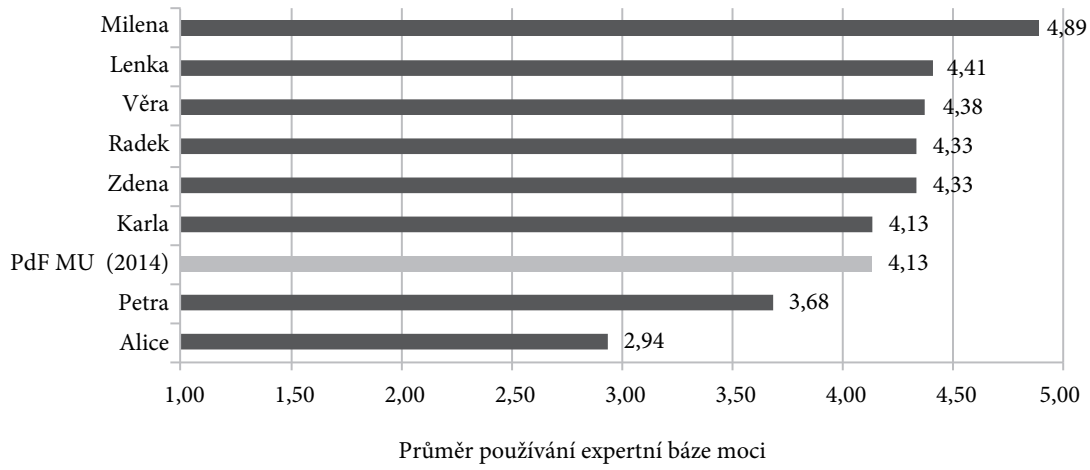

Poznámka. Odpovědová stupnice je od 1 do 5 (souhlasím).

Obrázek 9. Průměr používání expertní báze moci u osmi studentů učitelství ve vzorku.

Závěrem lze říci, že dosáhnout expertní moci je pro studenty snazší než dosáhnout moci v jakékoli jiné bázi (viz obrázek $5 \mathrm{v}$ kapitole 4.1, s. 61). Je tedy zřejmé, že v okamžiku, kdy se studenti ocitají před katedrou, se v očích svých žáků experty automaticky stávají. A pak je z velké míry v jejich rukou, zda se jim tuto moc podaří udržet a využít, nebo zda žákům zadají prŕíčiny k tomu, aby o jejich expertnosti začali pochybovat.

A jak se na sebe jakožto na experty dívají sami studenti učitelství? K otázce, zda se mohou považovat za experty a př́padně v jakých oblastech, se v rozhovorech sami opakovaně vracejí. Přestože jejich dosavadní praxe zatím čítá zpravidla do deseti vyučovacích hodin $\mathrm{v}$ jednom vyučovacím předmětu, hovoří o sobě v tom smyslu, že fázi úplných začátečníků již mají za sebou, což uvádí například Zdena: „Tohle jsem nevěděla jako začátečník, na to jsem přišla, až jsem prostě učila a třeba čtvrtou hodinu. "Svorně se však shodují na tom, že označení expert na sebe prozatím vztáhnout nemohou. To za všechny konstatuje napríklad Milena: „Tak odborník, si myslím, jako že ještě určitě nejsem. “ Ve svém hodnocení jsou tedy nakonec nejvíc prrísní studenti sami. A to je koneckonců dobře, protože k metě učitelů expertů (a to nejen z pohledu jejich žáků) je čeká ještě kus cesty. 


\subsection{Referenční báze moci aneb Dobrý učitel jako dobrý člověk ${ }^{43}$}

Tomáš Kohoutek, Jan Mareš

Vnímání učitelské role jako integrální součásti vlastní osobnosti je důležitým mezníkem v individuálním profesním vývoji (viz např. Day \& Sachs, 2005) a v podobě sebereflexe (Píšová et al., 2013) i důležitou součástí učitelské expertnosti. Referenční báze moci je pozorovatelnou ukázkou hledání rovnováhy mezi formálním výkonem učitelské role a jeho subjektivně uspokojivým individuálním pojetím, ze kterého může vyplývat jak vlastní pocit profesní kompetence, tak i nespecifické efekty edukace akcentující rovinu lidského setkání tady a ted' (viz např. Nohavová, 2012). Praktikující studenti učitelství jsou na počátku této cesty a je pochopitelné, že i jejich práce s tímto rozměrem výuky je (v porovnání s dalšími bázemi popisovanými v této monografii) spíše naznačena a mnohdy může být více intuitivní povahy.

\subsubsection{Podoby referenční moci}

Prototypickým, ačkoli poněkud zjednodušeným příkladem pro referenční bázi moci by mohl být stav, kdy žáci modifikují své chování tak, aby odpovídalo jejich pojetí učitele - jsou tedy sami nositeli motivu přizpůsobit se učiteli nebo jeho obrazu. Takto pojatá báze moci může působit ideálně až idylicky a jen stěží si lze představit, že by pro velkou část adeptů učitelství nebyla přitažlivá.

S ideálem a idealizací může mít referenční báze moci skutečně mnoho společného. V původním pojetí zdůrazňovali French a Raven (1959) právě aspekt identifikace, tedy pocit jednoty s někým, koho považujeme za svůj ideál, nebo touhu po takové identitě. Již tehdy také zdůraznili, že člověk si nemusí být vědom referenčního vlivu na sebe ani toho, že referenční mocí disponuje.

Pro výzkumnou praxi plyne z tohoto pojetí fakt, že se jedná o bázi velmi nesnadno uchopitelnou. Pokud nemusí být př́istupná vědomé reflexi vlastního nositele ani těch, které ovlivňuje, lze předpokládat, že i výpovědi o ní mohou být ochuzené nebo zkreslené. $\mathrm{V}$ rámci pozdějšího rozdělení na tvrdé a měkké báze moci (např. Erchul, Raven, \& Ray, 2001; Erchul, Raven, \& Whichard, 2001; viz též kap. 2) představuje bázi výsostně měkkou, tedy takovou, jejíž uplatňování může být téměř nežretelné. Oproti „tvrdým“ bázím moci se nemužeme opřít o jednoduchou definici odpovídajících projevư a je zřejmé, že k jejímu uplatňování nemůže být postačující vědomé rozhodnutí.

43 Za metaforu pocházející ze seminární práce „Jaký by měl být dobrý učitel?“ (Seminář k úvodu do psychologie, 2015) děkujeme studentce Pavle Myškové. 
Referenční moc představuje bázi, která je zvláště rezistentní vůči Weberově (1998) negativnímu pojetí konceptu moci jako „pravděpodobnosti, že jeden aktér sociálního vztahu bude $\mathrm{v}$ pozici, kde prosadí svoji vůli i přes rezistenci druhé strany“" (viz kap. 2.2 a 2.4). Nepředpokládá totiž rozpor ve vůli aktérů, ale naopak jejich souhru, př́tomnost rezistence je typická pouze pro negativní pól této báze moci v konkrétních podobách popisovaných např. Šedovou (2011). Referenční moc se spiše než na silově mocenské pozici zakládá na pozici výhodné pro vyjednávání a cestu $\mathrm{k}$ formálním či neformálním kontraktům v souladu s tím, co o nastolení klimatu vhodného pro učení uvádí Lewis (2001) - totiž že může být dosažen nejen důrazem na poslušnost a donucováním, ale právě i vyjednáváním se žáky, diskusí, skupinovou účastí a kontrakty (viz kap. 2).

S referenční bází moci jsou tedy koherentní taková pojetí moci (viz kapitola 2.1), jako je moc integrativní (oproti destruktivní a produktivní - Boulding, 1989) nebo koncepce konformity v reakci na požadavky učitele (Hammersley \& Woods, 1984), kdy žáci „nadšeně souhlasí s cíli učitele“. Velmi užitečné pro pochopení dynamiky referenční báze moci je i rozš́řené pojetí Šed’ové (2011), která kromě „zobání z ruky“ (to předpokládá sdílení cílů za současné dominance učitele) popisuje i fenomén „cirkulace moci“, kdy žáci sdílejí s učitelem cíle, avšak učitel přitom slevuje (třeba i částečně, na určitou dobu apod.) ze své dominance ve prospěch žáků.

Souhra, „konsilience“ mezi učitelem a žákem se jistě netýká výhradně cílů, zahrnuje i působení vztahu mezi aktéry. Obdobně jako o moci referenční se někdy hovoří o moci „charismatické" nebo „relačni“ a její uplatňování je dobře vidět na výukové praxi učitelů-expertů (viz např. Píšová et al., 2013). Přestože obě zmíněná pojetí nejsou s pojetím referenční moci v plném rozsahu zaměnitelná, vystihují některé velmi důležité aspekty prostřednictvím obecně srozumitelnějších termínů. Pojmenování „charismatická“ (Weber, 1998) zdůrazňuje vazbu na individualitu, nepřenosné autentické působení určité osoby, na druhé straně ale také určitou jednosměrnost a pozitivní hedonickou valenci působení, která nemusí být pro referenční moc nezbytně typická a je blízká spíše lidovému pojetí dobrovolně přijímané „přirozené autority“. Termín „relačni“" naproti tomu upomíná na obousměrnost či reciprocitu vztahu, jenž je prostorem realizace této báze moci. ${ }^{44}$ Vztah, který přesahuje rámec „ritualizovaných“ interakcí, se i v naší analýze ukazuje jako dosti klíčový moment pro identifikaci referenční báze moci.

Nejen pro uvedení úvodního „idylického“ pojetí referenční moci na pravou míru je však potřeba dodat, že takový vztah a jeho efekt nemusí být vždy pozitivní, zlepšující konsilienci a podporující cíle výuky. Raven při pozdější elaboraci (1992, 1993; viz též kap. 2.6) bází moci odlišil v rámci referenční moci pozitivní a negativní bázi. Negativní referenční moc stejně jako pozitivní ovlivňuje chování

44 Pro úplnost však dodejme, že může označovat i stav, kdy moc vyplývá např. z výhodné, nadřazené sociální pozice, z množství „výhodných“ vazeb apod. (Weber, 1998). 
žáků na základě jejich postoje $\mathrm{k}$ učiteli, žáci se ale chovají v př́mém rozporu nebo v protikladu k tomu, co vnímají jako cíle a požadavky učitele. V souvislosti s povahou níže prezentovaných empirických zjištění (zvláště poměrně těsné korelace mezi expertní a referenční bází moci z pohledu žáků, $\mathrm{r}=0,77)$ není bezvýznamné, že stejným způsobem (tj. na pozitivní a negativní formu) Raven rozdělil i moc expertní. Negativní expertní i negativní referenční moc přitom mají velmi obdobný účinek - distanci žáků od cílů a požadavků učitele, erozi jeho „autority“. Pozitivní modus se pojí s dosahováním výukových cílů, ale také s hodnocením učitele jako celkově „dobrého“. Ani vysoká vzájemná korelace však v tomto př́padě není důvodem ke „sloučení“ obou bází jako obsahově blízkých, jak tomu mủže být např́ílad v př́padě moci legitimní a donucovací (viz kapitola 4.1).

Zřejmá funkční odlišnost obou uvedených bází moci je patrná i v záměrném, explicitním důrazu na „referenční " působení a na efekt a podobu vztahu mezi učitelem a žáky $\mathrm{v}$ některých př́stupech. Rozvíjení vztahů může představovat nástroj posílení motivace žáků $\mathrm{k}$ učení i ke školní docházce jako takové. Smyth (2006) uvádí, že právě vztah může být důležitým motivem k učení a v některých případech také rozhodujícím faktorem, odpovědným za rozhodnutí ukončit školní docházku nebo v ní pokračovat. Připomeňme, že k sociokulturnímu kontextu školy patří to, že je povinná, žáci jsou „nedobrovolnými návštěvníky škol“ (Winograd, 2002), a jejich vlastní preference se tak mohou se školní agendou snadno rozcházet. Podněcování vlastních záměrů, práce s tím, co je na učivu zadaných úkolech relevantní vůči „self“ žáků, popisuje např. Kuhl (2000) jako jeden ze zásadních faktorů dynamiky motivace. $Z$ látky může něco atraktivního činit to, že je osobně významná, a tedy motivačně relevantní (Smith \& Lazarus, 1990). Tento efekt může působit přímo (učivo není pro žáky něčím odcizeným, nepochopitelným, ale vztahuje se k jejich zájmům i stávajícím strukturám poznatků), ale i zprostředkovaně („osobně věrohodně“ působí učitel pro obor zapálený, projevující zájem). Osobní rozměr vyjadřuje rovněž povaha interakce (např. již samo oslovení jménem, komunikace v duchu konverzace, projevy pochopení pro postupy nebo pocity žáků). Osobní, „sebe-relevantní aspekty mohou tvořit protiváhu k potenciálu školy pro disociaci vlastních zájmů od obsahu látky a úkolů, $\mathrm{k}$ anonymizaci i $\mathrm{k}$ jisté míre dehumanizace, která je pro hierarchické organizace typická.

Koncepce relational schools se dokonce explicitně vymezuje oproti převládajícímu paradigmatu disciplíny a předávání informací a zdůrazňuje jako zvláštní cíl budování silného společenského vědomí a společnosti jako takové. Linthicum (2006) považuje relační prrístup dokonce za polaritní vůči působení instituce: jde o to, zda se sami účastníme vytváření pravidel, nebo zda necháme instituci vytvářet pravidla pro nás (a za nás). Také tento př́stup zdůrazňuje reciprocitu, nikoli asymetrii rolí učitele a žáka a za cíl si klade právě rozvíjení schopnosti vyjednávání, hledání řešení typu „win-win“ namísto zaujímání opozičních stanovisek 
a budování vztahů důvěry, které jsou podpůrné a posilují resilienci jednotlivců i celých komunit (Pariser, 1999). Bez ohledu na vztah těchto koncepcí k pedagogickému mainstreamu ${ }^{45}$ je pozoruhodné pokročilé rozvinutí právě té složky působení učitelů, jež v některých př́padech zůstává nereflektovaná nebo se vedle jiných pedagogických důrazů, a vedle ostatních bází moci dokonce zdánlivě vytrácí.

\subsubsection{Operacionalizace a výsledky kvantitativní povahy}

Uvedené př́stupy jsou zřetelně vzdálené původní představě o identifikaci s nositelem (učitelem) jako hlavním principu referenční báze moci a o více či méně záměrné a reflektované snaze dosáhnout souhry typu „zobání z ruky“. Širší pojetí referenční moci, které zahrnuje osobní rozměr vztahu mezi učitelem a žáky, povahu interakcí mezi nimi, otázky pravidel a hranic, spolupráce, vyjednávání a cirkulace moci apod., však lépe odpovídá zvolené metodice, a to i na úrovni dotazníkového šetření. ${ }^{46}$ Zaměřme se proto nyní na operacionální vymezení referenční moci v této nejvíce strukturované části výzkumu.

Identifikaci ve smyslu rozhodnutí následovat učitele/učitelku jako vzor zjištuje jediná položka (Chtěl/a bych být jako tato učitelka), další se zaměřují na obecnější pocit sounáležitosti ( $S$ touto učitelkou mám hodně společného), na sounáležitost specifickou vzhledem $\mathrm{k}$ věku a pozici (Tahle učitelka je mi sympatická, protože se musí učit do školy stejně jako já), následuje dvojice položek orientovaných na soulad názorů (Já a tato učitelka máme stejný pohled na věc, Na věci se dokážu dívat stejně jako tato učitelka), kvalitu interakce iniciované učitelem/učitelkou (Tato učitelka se mnou jedná na rovinu, Tato učitelka je vůči mně vstřícná), př́padně na věrohodnost a význam sdělení ( $T o$, co říká a dělá tato učitelka, je pro mě důležité) a neformální či osobní rozměr vztahu mezi učitelem/učitelkou a žáky (Tuhle učitelku beru jako kamaráda, S touto učitelkou si rád/a povídám i o prèstávce).

Při vědomí toho, že práce s průměrnými hodnotami je pouze orientační $\mathrm{v}$ tom smyslu, že opomíjí nap̌r. individuální styl výuky učitele (Mareš et al., 1996), se na základě výsledků jeví jako nejvýraznější indikátory referenční báze moci hodnocení přístupu učitele (vstřícnost, př́mé jednání) spolu s vnímáním učitele nejen jako zástupce určité role, ale i jako člověka. Následují charakteristiky zahrnující výukový proces či jeho obsah (učitelka - studující jako někdo, kdo se také musí učit; význam sdělení), méně typický je naopak soulad názorů a jako spíše marginální se jeví prvky neformálního nebo symetrického vztahu a identifikace s učitelem jako se vzorem.

Identifikační a vztahové „jádro“ referenční báze moci je tedy u většiny studentů - učitelů $\mathrm{z}$ našeho vzorku spíše okrajovou záležitostí, na jejich př́ístupu

45 Pariser (1999) se v tomto smyslu vymezuje vůči převažujícímu pojetí školství v USA, které pokládá za „information rich, and responsibility poor“.

46 Původní Ravenovo pojetí považujeme skutečně za úzce vymezené, limitované představou identifikace jako jediného principu reflektujícího osobní rozměr vztahu; co je součástí „širšího pojetí", je obtížné vyčerpávajícím způsobem definovat, uvedený výčet spíše ilustruje různé aspekty referenční báze moci; vystihnout její povahu a principy je ve skutečnosti spíše otázkou, cílem této výzkumné sondy. 
jsou pozitivně hodnoceny ty interakce, jejichž povahu určuje ze své strany učitel/ učitelka. Osobní rozměr vztahu žáků a učitele je reflektován spiše v obecné rovině - žáci nepojímají kategorie „učitel“ a „člověk“ jako separátní nebo disociované, neupírají učiteli charakter lidské bytosti, ale nic víc. Pro atraktivitu učitelů je dále relativně důležité, že jsou současně studenty, mají (v něčem) stejné povinnosti jako žáci, a jsou tak „na jedné lodi“. Svět jejich názorů a požadavků je spíše odlišný od světa názorů a představ žáků, prostor pro vyjednávání „společného“ je limitovaný. Až na výjimky nelze hovořit ani o výraznější neformální nebo symetrické rovině vztahů, identifikace s učitelem nehraje ve srovnání s jinými aspekty této báze moci významnou roli (viz tab. 9). Svou roli zde může hrát i věk žáků, kdy student učitelství je chápán jako dospělý a díky věkovému rozdílu nemůže být žáky chápán způsobem, který předpokládá původní verze škály TPUS Schrodta, Witta a Turmana (2007).

\section{Tabulka 9}

Položky referenční báze moci u studentů učitelství ve výzkumném vzorku

\begin{tabular}{|c|c|c|c|c|c|c|c|c|c|c|}
\hline $\begin{array}{l}\text { Položky refe- } \\
\text { renční báze } \\
\text { moci }\end{array}$ & 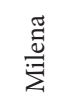 & $\underset{\Xi}{\stackrel{\pi}{ \pm}}$ & 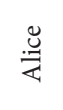 & 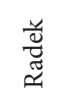 & 䓤 & $\frac{\mathbb{Z}}{\mathbb{U}}$ & $\frac{\pi}{\tilde{Z}}$ & $\stackrel{\square}{\circ}$ & $\begin{array}{c}\text { Studenti } \\
\text { PdF MU } \\
(2014)\end{array}$ & $\begin{array}{c}\text { Průměr } 8 \\
\text { studentů } \\
2015\end{array}$ \\
\hline $\begin{array}{l}\text { R08: Tato uči- } \\
\text { telka je vůči } \\
\text { mně vstřícná. }\end{array}$ & 4,60 & 3,76 & 3,25 & 4,00 & 4,63 & 4,00 & 4,40 & 4,21 & 4,07 & 4,11 \\
\hline $\begin{array}{l}\text { R10: Tato uči- } \\
\text { telka se mnou } \\
\text { jedná na ro- } \\
\text { vinu. }\end{array}$ & 4,67 & 3,81 & 3,67 & 3,86 & 4,63 & 3,36 & 3,93 & 3,79 & 4,12 & 3,96 \\
\hline $\begin{array}{l}\text { R13: Tuto } \\
\text { učitelku vidím } \\
\text { i jako člověka, } \\
\text { nejen jako } \\
\text { učitelku. }\end{array}$ & 4,75 & 3,90 & 2,67 & 3,00 & 4,32 & 4,55 & 3,67 & 4,67 & 3,99 & 3,94 \\
\hline $\begin{array}{l}\text { R04: Tahle } \\
\text { učitelka je mi } \\
\text { sympatická, } \\
\text { protože se musí } \\
\text { učit do školy } \\
\text { stejně jako já. }\end{array}$ & 4,87 & 3,52 & 3,08 & 4,00 & 3,79 & 3,96 & 3,60 & 4,07 & 3,83 & 3,86 \\
\hline $\begin{array}{l}\text { R41: To, co } \\
\text { říká a dělá tato } \\
\text { učitelka, je pro } \\
\text { mě důležité. }\end{array}$ & 4,36 & 3,57 & 2,92 & 4,00 & 3,79 & 3,78 & 3,20 & 3,93 & 3,57 & 3,69 \\
\hline
\end{tabular}




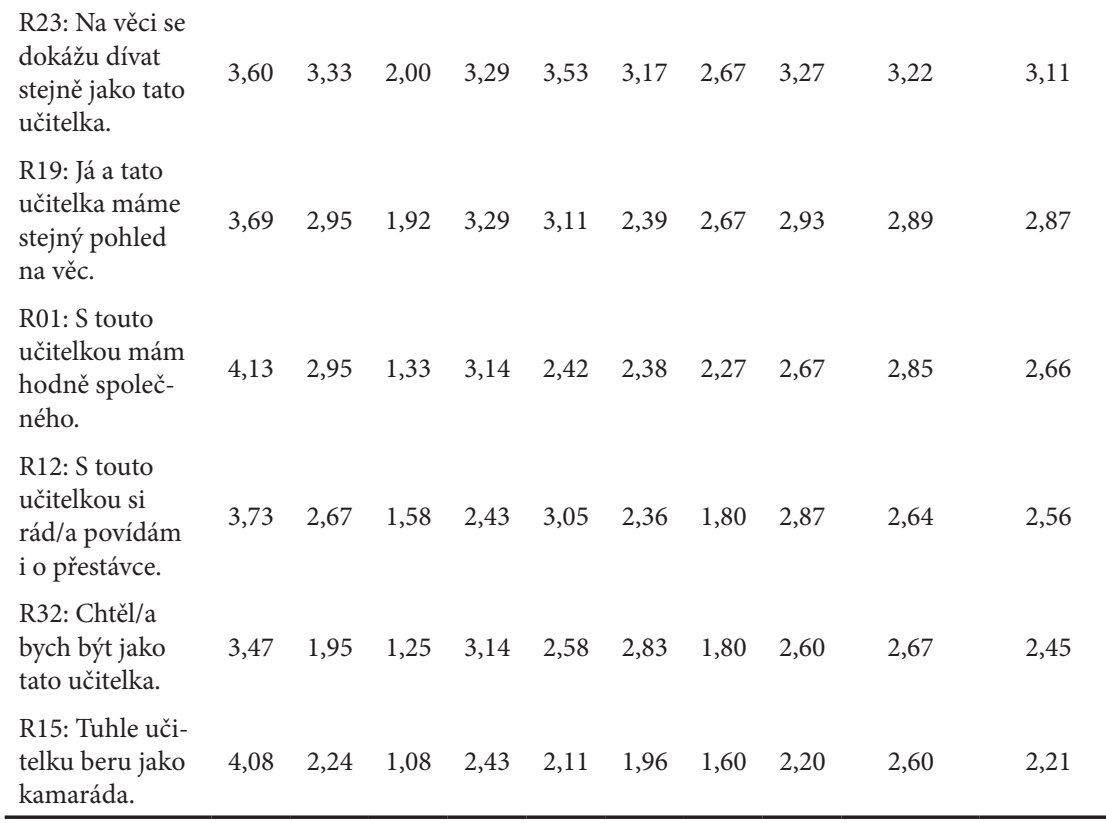

Poznámka. Odpovědová stupnice je od 1 (nesouhlasím) do 5 (souhlasím).

Mezi sledovanými bázemi moci ve výuce studentů učitelství má podle výsledků dotazníkového šetření referenční moc své významné místo, nicméně v našem vzorku je ze strany žáků její zastoupení zpravidla hodnoceno jako spíše průměrné (s jednou výjimkou v každém směru), obvykle dominuje moc expertní a odměňovací, s níž je referenční moc v některých případech prakticky rovnocenná, u jedné z participantek je však hodnocena dokonce jako vůbec nejméně zastoupená báze (viz obr. $6 \mathrm{v}$ kapitole 4.1, s. 64).

\subsubsection{Souvislosti s dalšími bázemi moci}

Velmi důležitým vodítkem pro identifikaci forem a užití referenční moci u studentů učitelství jsou i údaje o korelacích s ostatními bázemi moci, resp. strukturní model (více viz kap. 3.4.4 a Vlčková, Mareš, \& Ježek, 2015). Interkorelace škál dotazníku lze $\mathrm{v}$ tomto prípadě předpokládat, nebot jednotlivé škály reprezentují dílčí báze jednoho fenoménu; ve skutečnosti se moc ve školní tř́dě může (a měla by) opírat o kombinaci více bází. Také $\mathrm{z}$ individuálního rozdělení průměrného skóre je patrné, že realizace jedné báze moci se nevylučuje s realizací kterékoli $\mathrm{z}$ bází ostatních. Právě u referenční báze moci lze očekávat souvislost $s$ dalšími bázemi i z řady specifických důvodů. 
Jedním z nich je, že referenční moc je z velké části výsledkem předchozího působení, v plném rozsahu nevzniká „z ničeho“. Ani proměnné výchozí situace (např. to, že před třídu předstupuje studující, věkově i pozicí ve vzdělávacím systému relativně bližši žákům než jejich učitel/učitelka; atraktivitu vzhledu a projevu apod.) nelze sice podceňovat, takové aspekty komunikace jako vstř́ícnost, jednání „na rovinu“ nebo vědomí důvěryhodnosti a hodnoty sdělení však žáci jako komunikační partneři mohou posoudit až na základě delší a pravidelnější interakce. Učitelská praxe studentů je ale př́liš krátká a definici situace (Woods, 1979) nemají úplně pod kontrolou, protože ji před praxí i během ní ovlivňuje i supervidující učitel.

Na utváření pozice respektovaného člena společenství, vzoru nebo „charismatického" učitele se podílí i to, jak pracuje s dalšími bázemi moci. V rámci systému, který je orientovaný na dosahování výkonu, si lze stěží představit „pro-referenční, např. ryze „kamarádský“ prrístup jako jedinou metodu ustanovování moci a motivace žáků (srov. Šed’ová, 2011, s. 95). Zdá se prakticky nemožné uvažovat o tom, že by někdo byl od počátku „charismatický“ a přitom neprojevil odbornou zdatnost, nedokázal udržet pořádek ve tř́dě ani ocenit žáka. Daleko spíše tedy získá referenční pozici někdo, kdo současně mistrně zvládá některý z dalších způsobů uplatňování moci: působí jako expert, je schopen dobře nastavit legitimní pravidla, spravedlivě hodnotí a efektivně odměňuje. V jiném kontextu studenti např. označili za projev lidského přistupu i to, že učitelka na začátku kurzu „jasně sdělila požadavky a co se stane při nesplnění a dodržovala to“. Analogicky nepřiměřenost $\mathrm{v}$ nastolování moci na určité bázi může mít devastující vliv na referenční bázi moci: selhání v roli experta (např. učitel tvrdí něco, co prokazatelně neodpovídá skutečnosti), nepřiměřené (např. př́liš nízké nebo př́liš vysoké) legitimní nároky, nedostatky ve zpětné vazbě žákům i nezvládnuté incidenty mohou ovlivnit i pozici učitele jako referenční figury (srov. Makovská, 2011 či Šed’ová, 2011).

Referenční charakteristiky jako aspekt některé z ostatních bází moci jsou s to na druhé straně opět přispívat k jejímu upevňování: legitimní požadavky může snáze vznášet ten, s kým žáci sdílejí představy, a na základě dobrého vztahu jsou připraveni mu vyhovět; jako odborník se žákům může učitel jevit nejen na základě informační převahy, ale také díky „nakažlivému“ nadšení, osobnímu zájmu o obor, stejně jako součástí expertnosti může být schopnost přiblížit se žákủm, předávat jim poznatky pro ně př́ístupným, srozumitelným způsobem a probouzet vnitřní motivaci ke spolupráci i k osvojování učiva; referenční osoba také snáze odměňuje (zájmem, společnou činností, projevem pozornosti), aniž by se musela např. podbízet nebo redukovat pojetí odměn na utilitární.

Naopak nedostatek nebo absence projevů zájmu, pochopení pro žáky nebo jejich sympatií může jakoukoli další bázi moci oslabovat nebo podkopávat. Referenční báze má vztah k povaze a kvalitě interakcí, přičemž kterákoli forma moci 
musí být komunikována. „Moc a komunikace vzájemně těsně souvisí,“ uvádějí McCroskey a Richmond (1983, s. 175) a dále: „Při absenci komunikace je tedy učitel ve tř́íle bezmocný. Způsob, jakým učitel komunikuje se svými studenty, pak z větší části determinuje typ a rozsah moci..." Tento názor považujeme také za klíčové východisko pro interpretaci výpovědí a záznamů výuky po stránce identifikace referenční báze moci. Způsob komunikace je tím, co může referenční charakteristiky odrážet významnější měrou než naše vědomé rozhodnutí a reflektovaná snaha působit jako „referenční figura“.

Ve strukturním modelu (kap. 3.4.4 a detailně ve Vlčková, Mareš, \& Ježek, 2015) jsou skutečně zřejmé poměrně těsné pozitivní i negativní korelace referenční báze moci se všemi ostatními bázemi. Velmi těsný a takřka deterministický vztah $(0,77)$ má referenční moc k moci expertní. Jen o málo slabší $(0,69)$ je vztah $\mathrm{k}$ moci odměňovací. Mírně také koreluje s mocí legitimní/donucovací $(-0,21)$.

Vzorec korelací je konzistentní s nastíněnými teoretickými předpoklady. Báze moci se ve vztahu k bázi referenční diferencují na dvě skupiny - ty, které odpovídají žádoucím rysům „dobrého" učitele (možná spíše ve smyslu oblíbenosti), a ty, jež s tímto obrazem mohou být (ne vždy však také jsou) v rozporu.

Pokud bychom posuzovali vztah referenční a expertní báze moci pouze na základě zjišsěné hodnoty korelačního koeficientu, byla by na místě i úvaha, zda se ve skutečnosti nejedná o jedinou přiměřeně homogenní škálu. Domníváme se, že tak těsný vztah byl identifikován i v důsledku zvoleného metodologického postupu: svou roli sehrála pozice posuzovatelů - žáků, kteří ve skutečnosti obě báze hodnotili jako aspekty působení „dobrého“ učitele. Obě báze jsou však z definice funkčně odlišné: zatímco odbornost se vztahuje k poznatkové a informační vybavenosti učitele, jeho atraktivita je funkcí kvality kontaktu se žáky. V daném př́padě můžeme však uvažovat i o tom, že obě báze se vzájemně podmiňují. Vzorem, „osobou hodnou následování, se stěží stane někdo, kdo se žákům nejeví jako odborně zdatný, a člověk, který si nezíská alespoň mírné sympatie žáků a jeví se jim jako cizorodý prvek, patrně obtížně upoutá jejich pozornost natolik, aby byli vưbec schopni posoudit jeho odborné kvality. Pozitivní modus referenční a expertní moci se navíc mohou vzájemně posilovat. Pozitivní hodnocení expertnosti souvisí nejen s orientací učitele v oboru, ale is tím, nakolik je schopen učivo žákům zprostředkovat.

Je vhodné rovněž připomenout, že u obou zmíněných bází byl popsán i modus negativní. Jak u expertní, tak u referenční moci je zpravidla spojen s nedostatky $\mathrm{v}$ dané bázi moci - učitel mocí na této bázi disponuje nebo nedisponuje. Lze sice uvést př́klady záměrného využití negativní referenční moci, jsou ale spíše výjimečné a $\mathrm{z}$ hlediska přijatelnosti sporné: může se jednat např. o postup, kdy učitel vyvoláním odporu vưči své osobě (zadáním nesplnitelného úkolu, arogantním jednáním...) posílí kohezi třídy jako kolektivu v rezistenci. Podobně záměrná rezignace na expertnost může být výrazem delegování kompetencí (ve vyhledávání 
informací, vyvozování závěrů...) na stranu žáků, nepř́mý apel na jejich samostatnou iniciativu, rovněž její využití je ale limitované a v běžných podmínkách spíše vzácné. Negativní modus expertní i referenční báze moci je zpravidla spojen s neochotou žáků spolupracovat nebo i s aktivním odporem. Projevy jsou tedy $\mathrm{v}$ obou př́padech stejné, ačkoli může být užitečné vědět, nakolik je jejich příčinou deficit v odbornosti či deficit ve vztahu.

Při dané operacionalizaci referenční a odměňovací báze moci lze předpokládat také jejich těsnou souvislost. První směr vzájemného ovlivňování může vést od odměňování k pozitivnímu vztahu: pokud učitel odměňuje, získává si žáky „na svou stranu“, buduje svou oblibu, at se již z jeho strany jedná o projev pozitivní motivace a pozornosti vůči úspěchům žáků nebo o projev „pedagogického populismu“. Pozitivní projevy budují vztah. Naznačena ale byla i možnost opačného směru ovlivňování: oblíbený či „charismatickýc učitel musí vynakládat menší úsilí na to, aby jeho jednání bylo žáky přijímáno jako forma odměny. Otázky dotazníku se také zaměřují především na pochvalu jako formu odměny. Pochvala mưže být vnímána jako projev pozornosti, zájmu („učitel/ka mě vnímá, všímá si mě, je pozorná"), dobrá úroveň komunikace je zároveň předpokladem pro vytváření dostatku př́ležitostí $\mathrm{k}$ pochvale.

Na negativním vztahu referenční a legitimní, resp. donucovací báze moci se opět může podílet několik faktorů včetně operacionalizace. Legitimní moc je v dotazníku reprezentována nejen položkami zaměřenými na institucionálně ukotvenou autoritu učitele, ale i sledováním projevů nezájmu či bagatelizace projevư žáků a celkového odstupu učitele od žáků, je tedy operacionalizována do značné míry jako protiklad moci referenční. Sleduje také, nakolik se učitel - studující odvolává na autoritu cvičného učitele, jakoby „nejedná za sebe“, což může svědčit o rezervách v navazování dvoustranného vztahu se žáky. Donucovací moc sleduje mimo jiné i autentické pocity žáků a vyžadování či kontrolu ze strany učitele. Pokud se žák např. při nesplnění úkolu „cítí opravdu špatně“, může tomu tak být právě proto, že nechce narušit vztah s učitelem, vưči referenční figuře ,je mu to hloupé“. Zahrnuje i negativní reakce učitele na chování nebo výsledky žáků, i ty lze však chápat jako projev pozornosti.

$Z$ věcného hlediska lze středně těsný nebo mírný negativní vztah vykládat ve smyslu možnosti či rizika, že sledované jevy jsou i funkčně v protikladu, nikoli jako absolutní protiklad. Práce s legitimní nebo donucovací bází moci tedy může souviset s nižší mírou moci referenční, vzájemně se však nevylučují. Za pozornost stojí, že posluchačky s největší mírou projevů legitimní a donucovací moci měly současně bud' nejvyšší, nebo nejnižší hodnocení referenční báze moci. Osoba, která funguje jako referenční figura, může mít výhodnější pozici pro formulování a kontrolu požadavků, v rámci individuálního stylu se takové jednání dá chápat jako projev celkové angažovanosti ve výuce a zájmu o výsledky žáků. Podobně lze ale popsat situace, kdy nadužití prostředků typických pro 
legitimní a donucovací bázi naruší rozvoj vztahu a utváření vlastní referenční pozice nebo kdy je jejich využití důsledkem deficitu referenční moci jako zdroje "přirozené autority“.

\subsubsection{Kvalitativní zdroje - záznamy a výpovědi v rámci rozhovorů}

Extenzivní kvantitativní šetření poskytlo důležité informace o existenci a těsnosti vazeb referenční báze moci k dalším bázím. Pracovní hypotézy o podobě těchto vztahů jsou však často obousměrné (jednotlivé báze se mohou např. jak vzájemně posilovat, tak rušit), máme také jen málo nápovědí pro interpretaci ve specifickém kontextu působení studujících v roli učitele. V souladu se zvolenou formou smíšeného výzkumu (viz kap. 3) tvoří kvantitativní analýza rámec pro interpretaci kvalitativních výpovědí, které figurují jako zdroj př́mých náhledů na konkrétní specifickou situaci participantů. Závěry o míre a podobě referenční báze moci v působení studentů učitelství proto $\mathrm{v}$ další fázi opíráme právě o tento zdroj.

Vyskytl se určitý paradox, že pasáží, jež lze vztahovat př́mo k referenční bázi moci, je ve výpovědích studentů učitelství poměrně málo. Objevují se jako předmět úvah či pochybností o tom, zda a do jaké míry je jednání na této bázi žádoucí, dále jako „povzdechy“ nad omezeným prostorem pro kultivaci vztahů se žáky a nakonec jako aspekty neoddělitelné od dalších bází např. při výkladu nebo při komunikaci nad úkolem - i zde může př́tomnost nebo deficit „referenčního“ přístupu modifikovat nebo determinovat celkové vyznění výukové situace.

\subsubsection{Studující - učitel jako komunikační partner žáků}

$\mathrm{V}$ této kapitole se zaměříme na blízkost a hranice $\mathrm{v}$ kontaktu studenta učitelství se žáky, na neformální dimenzi jejich kontaktu a na práci s motivací, nebot tyto kategorie výrazně definují studenta učitelství jako komunikačního partnera žáků.

\subsubsection{Blízkost a hranice}

Pozice studujících v roli učitelů je v řadě ohledů odlišná od pozice učitelů (viz kapitola 4.2). Žákům jsou v mnohém „blíže“ než „skuteční učitelé“, existuje ale i řada skutečností, které mohou je a žáky vzájemně „vzdalovat“. Není zcela automatické, že budou působit jako „referenční figury“.

Jako dobrá ilustrace může sloužit „mechanický“ předpoklad o významu věkové blízkosti při utváření vztahů. Jak jsme již uvedli, z pohledu žáků může být věkový rozdíl ve skutečnosti značný - studující jsou dospělí lidé podobně jako ostatní učitelé. Ani situace, kdy jsou studující skutečně žáky vnímáni jako věkově (a tedy implicitně i osobně) bližší, není prostá problematických momentů. 
Signály ze strany žáků nemusejí studující vyhodnotit jako „bezpečné“, záleží na povaze těchto signálů i na pojetí vlastní role učitele.

\section{Ukázka 81}

\section{Studentka Zdena, rozhovor}

Studentka: To jsme byli vlastně, do divadla jsme šli. Tak to ještě nic, to jsme se nebavili s děckama. A když jsem šla zpátky, tak se ke mně vlastně přidala jedna holka, která tam neměla zas až tolik kamarádů, a chtěla si vykládat se mnou, no. Tak a to byli devátáci, takže jsme si vykládali, kam jde na školu, a třeba si stěžovala, že ve tř́iě není zas až takovej kolektiv dobrej. A že tam není moc spokojená, až prostě odejde na střední, že doufá, že to tam bude lepší. Takže takhle nějak jsme si povídaly, no.

Tazatel: Ahm. Bylo to pro vás př́ijemné nebo nepř́ijemné třeba, lehké nebo těžké...

Studentka: Jo, pořád jsem si říkala, že hlavně se nesmím rozkecat tak, jako třeba s kamarádkou, jo, když se mě ptala třeba, co škola a tak. Že prostě si musím tam pořád udržovat pořád ten vztah nadřízenosti nebo nadřazenosti nebo jak to mám říct. Protože (.) to nesmí sklouznout $\mathrm{k}$ tomu, že si budem vykládat. Protože já jsem taková, že jako docela mluvím jakoby se staršíma nebo se sobě rovnejma docela otevřeně, že jako nemám žádný témata jako tabu. Takže tam jsem si musela dávat pozor, abych jakoby udržela ten vztah.

„Výzva“ ze strany žákyně tedy u studentky učitelství aktualizovala spíše potřebu „udržení hranic“, obranné nastavení, chránící „nadřazenost“ nebo „nadřízenost“ jako neodmyslitelnou součást jejího pojetí role učitele - autority v asymetrické pozici. Tuto pozici potřebuje udržet právě proto, že její kontakt se žáky netrvá dlouho, pozice dosud není vymezena a její pojetí sdíleno, pozice autority se také nemůže opírat o věkovou bariéru či „propast“. Dotaz žákyně na školu zdůrazňuje studentskou roli učitelky, která $\mathrm{k}$, autoritě“ ve smyslu oddělenosti nemusí přispívat. Studentka nemůže vědět, jaké důsledky může mít nastolení „kamarádské“ pozice, jak by se pak mohl změnit vztah nejen s žákyní, s níž hovoří, ale i s ostatními žáky. Velmi významným detailem je, že se nachází zrovna v roli „pedagogického dozoru“, osoby, která dbá na disciplinovaný přesun třídy a nese odpovědnost za bezpečnost, která závisí na prosazení její vůle. Jsou tak jasně dány priority působení, mezi něž „kamarádský vztah“ nepatří. „Výzvu“ proto vnímá jako signál možného ohrožení bezpečné, ale nikoli pevné role. Toto riziko je paradoxně zesilováno i její sdílností, jíž si je vědoma a záměrně ji kontroluje a potlačuje.

Jedná se přitom o běžnou konverzační situaci. Častým jevem je přitom i „testování" stability učitele a jeho role ze strany žáků, které může mít povahu explicitního „atakování hranic“, jež může potřebu uchování takových hranic nepochybně vyvolávat $\mathrm{v}$ daleko větší míře. 


\subsubsection{Neformální dimenze kontaktu}

Následující ukázka přináší další příklad poměrně „mírumilovného“ atakování legitimně nastavených hranic, tentokrát s kladnou odezvou ze strany studující.

\section{Ukázka 82}

\section{Studentka Lenka, rozhovor}

Tazatel: A s čím třeba choděj a kdy?

Studentka: No, to chodili v devítce. Deset minut jsem je hlídala, paní učitelka tam nebyla. Samožrejmě oni nesmí používat mobily, tak jestli si můžou napsat SMS. Tak jako že jo. Protože oni neměli jako co dělat, oni prostě měli bejt v klidu. Tak se tam jako ty holky srocovaly, pak mně ty SMS ukazovaly, že jí píše nějakej neodbytný kluk a že ona neví, co má odepsat, tak že to nechala napsat tu svoji kamarádku. Takže to byly takový zprávy. Podívejte se paní učitelko, co mně přišlo? A tak.

V tomto př́ípadě studentka opět vykonávala dozor (avšak pouze o přestávce) a žáci - či spíše žákyně - nejvyššího ročníku ZŠ přišly „,yjednávat“ o nezbytnosti dodržet „legitimní pravidla, která patří k místní konvenci. Studentku vnímaly jako prvek, jenž takové konvenci v plném rozsahu nepodléhá a nemusí ji sdílet, může mít své vlastní motivy, odlišné od školní rutiny. V tom je „lidštějši“‘, bližší světu žákyň a je možné, že bude mít pro jejich přání pochopení. Zvolená forma oslovení přitom „ctí autoritu v tom, že žákyně žádají o legitimizaci svého přání pro daný komunikační kontext, nezačnou samy používat mobily bez ohledu na prítomnost dozoru.

Studentka jim vyjde vstříc, což je pro žákyně signálem k tomu, aby ji začaly vnímat jako komunikační partnerku i ve vztahu k obsahu jejich komunikace s osobami vně situace. Zesílí jejich sdílnost, studentku považují za „konzultantku“ v osobních otázkách. Studentka se nezmiňuje o tom, že by to v ní vyvolávalo odpor či pochybnosti o vlastní roli, rozšíření svých „kompetencí přijme. Na jedné straně se tak intuitivně přibližuje pojetí školy jako prostředí, kde se o pravidlech vyjednává, namísto aby se očekávalo podřízení, na druhé straně potvrzuje, že není bezvýhradně identifikovanou součástí školy s jejími konvencemi. Komunikace je jí v její pozici bližší než uchování konvencí.

Hned v následující sekvenci rozhovoru se však věnuje i tomu, že pro systematické rozvíjení osobní, neformální dimenze kontaktu nemá na praxi příliš prostor.

\section{Ukázka 83}

\section{Studentka Lenka, rozhovor}

Studentka: Na to musí vzniknout taky ten prostor. Jinak není kde. To akorát po hodině že někdo přijde, když se balej, že, ale to není taky nic osobního. Pak 
ráno třeba, to jsem se bavila s chlapečkem, protože jsem ho potkala $\mathrm{v}$ šatně, viděla jsem, že má berle, ortézu, a tak jsem se ho jako ptala, co se mu jako stalo a tak. A zjistila jsem, že on už tu ortézu má (.) od narození?

Já už v tý třídě učím hrozně dlouho a vủbec jsem si nevšimla: ortézu a berle, jo? To jsem si všimla až v tý šatně. Jo? No, jinak tam vlastně není prostor. Těch 10 minut přestávky, to je vlastně málo.

Jako prŕležitost navázat kontakt se žáky vnímá spíše přestávky, které jsou krátké. Samotná výuka pro ni nepředstavuje zdroj prŕiležitostí zaznamenat důležité individuální charakteristiky. Podivuje se nad tím, že až při dozoru v šatně si všimla, že jeden z žáků má ortézu a berle - jakoby s sebou kontext výuky nesl určitý druh „slepoty“ vůči významným prvkům komunikačního kontextu. Není jí přitom vlastní takové okolnosti přehlížet, v šatně projevuje zájem o to, co se „chlapečkovi“ stalo a později se podivuje spíše tomu, že si dříve nevšimla. Z jejího vyprávění je zřejmé, že osobní rozměr kontaktu se žáky jí není cizí, ale vnímá jeho deficit jako deficit podmínek v kontextu krátkého působení, zaměřeného spíše na výuku.

Oba uvedené prríklady spojuje důraz na „jiné priority“. Role studujících na praxi nesouvisí s jejich věkem jen ve smyslu fyzikálně-časového odstupu od věku žáků (ten je samozřejmě nižší než u učitelů kdykoli jindy v průběhu profesní dráhy), ale i se zranitelností role učitele (ale třeba i pedagogického dozoru apod.), s tím, že primárně jsou plněny povinnosti vyžadované a hodnocené školou a cvičnými učiteli, i s tím, že pobyt mezi žáky je poměrně krátký na to, aby se mohly srovnatelně rozvinout formální i neformální složky vztahů. Studující mají "předvést, co umějí - a to se týká především zvládnutí obsahu výuky. Každá hodina je připravována jako premiéra, někdy studujícím dokonce více připomíná situaci zkoušení než předávání poznatků. ${ }^{47}$ Osobnější př́stup k žákům, konzistentní s referenční bází moci, se může odehrávat na hraně legitimity (nebo i za ní).

\subsubsection{Začínající expert a práce s motivací}

$\mathrm{Na}$ základě předchozích ukázek by se mohlo zdát, že referenční báze moci je okrajová, její zdroje i prostor pro realizaci se nacházejí v krátkých časových úsecích mezi vyučovacími hodinami a "hlavními“ školními aktivitami vůbec a že tvoří jakýsi doplněk nebo dokonce protipól aktivitám legitimním. S tímto obrazem je však $\mathrm{v}$ př́íkrém rozporu těsná korelace $\mathrm{s}$ expertní bází moci, jinými slovy, variabilita expertnosti v očích žáků takřka kopíruje variabilitu referenčních charakteristik, rozdíly mezi vyučujícími připisované jejich expertnosti prakticky splývají s popisem rozdílů jejich působení jako referenčního. $\mathrm{V}$ předchozím textu jsme se zabývali několika možnými obecnými důvody: žáci nemusejí být schopni

47 Často formulovanou obavou v prvních hodinách semináře k učitelské praxi je: „Co když se mě žáci nebo cvičný učitel zeptají na něco, co nebudu vědět?“ 
identifikovat „čistou“ odbornost, pokud není dobře komunikována, obě charakteristiky mohou být jen facetami obrazu „dobrého učitele“, absence (resp. negativní modus) každé $\mathrm{z}$ obou bází moci má stejný důsledek v nespolupráci žáků apod.

Poněkud provokativní ${ }^{48}$ titulek mírí $\mathrm{k}$ dalšímu možnému zdroji souvislosti: již u učitelů-studentů může být znatelnou součástí odbornosti i schopnost přistupovat $\mathrm{k}$ výuce $\mathrm{s}$ dávkou empatie, pracovat $\mathrm{s}$ jejich motivací, ale i s emočním laděním a identitou, pojímat vyučovací hodinu i jako vzájemné setkávání. Označení „expert“ $v$ našem prrípadě neoznačuje mimořádně „ostřílené“ veterans. Také působení začínajících učitelů-studujících v našem výzkumu, kteří vykazovali zároveň vysokou úroveň expertní i referenční báze moci, však vykazuje podobné rysy, jaké Píšová et al. (2013) popisují u expertů - velmi zkušených učitelů. Ačkoli je možné, že plnému využívání expertní i referenční báze moci musí předcházet opadnutí trémy a obav vázaných na úplné počátky působení v roli učitele, důležitou specifickou roli může $\mathrm{v}$ počátcích profesní dráhy sehrávat i entuziasmus a odhodlání „hledat“49.

K významným příspěvkům, které Píšová et al. (2013) zmiňují, patří Deweyho (1936) pojetí učitele jako alive, živého „v plnosti svých mentálních, fyzických, emočních a vztahových zdrojů (Píšová et al., 2013, s. 39) - tato charakteristika se pak může ve vnímání žáků odrážet jako „je to nejen učitel, ale i člověk“ a dále $\mathrm{v}$ emoční angažovanosti učitele ve výukové interakci ve smyslu vytváření suportivní a pracovní atmosféry ve třídě (Píšová et al., 2013, s. 39). „Živá“ je pak i interakce mezi učitelem a žáky, učitel vytváŕí pro žáky i pro sebe př́ležitost $\mathrm{k}$ autentickému projevu a díky tomu se aktéři na obou stranách i lépe a rychleji poznávají.

Pokusme se souhru odbornosti a referenčního modu ilustrovat pomocí př́ikladů, které již byly v souvislosti s expertní bází moci uvedeny (viz kapitola 4.5), interpretace však tentokrát bude směřovat na prvky využití referenční báze moci.

V prvním př́kladu (studentka Lenka) zdařilý výklad podněcuje k odpovědím, udržuje pozornost, motivuje názorností, oboustrannou komunikací i zapojováním emocí, studentka dává najevo také signály o svém vztahu k žákům. Druhý př́klad (studentka Karla) představuje zadání „nesplnitelného“ náročného úkolu okrajového významu, který v žácích vzbuzuje pochybnosti o vlastních schopnostech, smyslu úkolu, výukové situaci i o správnosti jednání učitelky.

48 Píšová et al. (2013, s. 11) v souvislosti s výzkumem učitelů - expertů uvádějí, že se „V některých doménách k označení velmi zkušeného jedince používá v anglickém jazyce pojem veteran ve smyslu mající množství zkušeností..."Představa experta - začátečníka se tak může jevit jako paradox.

49 „Analýza dále ukázala, že učitelé experti projevují trvalou a aktivní snahu porozumět jevům (i žákům), směřují ke stále hlubšímu pochopení, nejen „vědi““, tj. mají hluboký vhled, ale zároveň stále „hledají, jak se dostat ještě dál, vhlédnout ještě hlouběji“ (Píšová et al., 2013, s. 37). 


\section{Ukázka 84}

\section{Studentka Lenka, výuka dějepisu, první hodina}

U: Prusů bylo více, měli více děl a skončilo to opravdu drtivou porážkou Francie. Tam Francie měla v bitvě zhruba 120 tisíc mužů a $\mathrm{z}$ toho jich bylo okolo 103 tisíc zajato a asi 17 tisíc zabito a Prusové ztratili jenom 9 tisíc mužů, ti jich měli asi 200 tisíc. Takže to bylo opravdu, opravdu jasné. Tak (.) ta bitva u Sedanu, co je to ten Sedan?

\section{ŽŽ: Město.}

U: To je město. Vidíte, vidíte ho i na svojí (.) svojí mapě, že jo? Vidíte. Nachází se ve Francii, takže ve městě se opevnil kdo?

K: Francouzi.

U: Francouzi. A zhruba ve čtyři hodiny ráno na ně zaútočili (.) zaútočili ti Prušáci. Když chcete na někoho takhle zaútočit, jak je to lepší? Když jste vy jako...

K: Na koních.

\section{ŽŽ: ((zasmějí se))}

U: Jo, na koních, může být, ale myslím jakoby geograficky.

K: Palbou.

K: Tak na kopci.

U: Na kopci. Takže Prušáci byli na kopci a pálili dolů na to město. Jo? Takže proto ta bitva trvala, ona trvala asi hodinu jenom. Jo? Oni je prostě hnedka, hnedka zmasakrovali.

K: Oni to čekali?

U: Ano, oni to čekali. Oni přijeli, ti Prušáci je- několik dní obléhali v tom Sedanu, takže oni to čekali, ale nemohli nic dělat, protože byli v tom městě. K: A jo.

U: Jo? Ehm (.) takže tam máme vyhlášeno- jo, tady máte ješš tu kapitulaci, jak na tom obrázku Napoleon III. kapituluje, a je tedy zajat.

Analýza interakce po stránce expertní báze moci (s. 139) se zaměřuje na styl výkladu a způsob sdělování látky. Z hlediska referenční báze moci je zvláště zajímavé, jakého prostoru se dostává žákům. Studentka výklad kombinuje se zadáním úkolu - po expozici „kontroluje“ otázkou jejich porozumění („Co je to ten Sedan?"), pak klade sugestivní otázku („Když chcete na někoho zaútočit, jak je to lepší?"), která navozuje u žáků pozici toho, kdo řeší problém. Neobdrží správnou odpověd, ale to nevadí, nechává prostor pro smích, pro další tvoření alternativ odpovědí. Pozoruhodné a významné je, že další otázka již přichází od žákủ. Učitelka přitakává a v odpovědi dále rozvíjí výklad. Ten má ale již formu dialogu - další replika ze strany žáka „jen“ konverzačně vyjadřuje porozumění. Je zřejmé, že žáci mají zájem o informace a ona je v roli experta - toho, kdo informace poskytuje. Nelze ale podcenit ani její roli „moderátorky“ úvah a konverzačního zapojení 
žáků, která sahá od přípravy (nachystané „udičky“ pro vtažení žákủ do výkladu) přes práci s emocemi (emočně zabarvené líčení, ale i prostor pro smích) a s replikami žáků (nehodnotí, navazuje) po vedení žáků k vlastnímu hodnocení správnosti odpovědí a po motivaci k hledání dalších alternativ.

Druhá ukázka představuje méně zvládnutou komunikační situaci - zadání úkolu, jenž je (z hlediska expertního př́istupu) jednak nedostatečně vysvětlen, jednak nepřiměřeně prezentován jako učivo, které se nebude testovat (viz s. 153). Z hlediska referenční báze je opět zajímavá spíše práce s replikami žáků.

Ukázka 85

Studentka Karla, výuka dějepisu, první hodina, zadání „nesplnitelného“ úkolu

U: Všech těch 12 požadavků rozdělit, jestli je to státoprávní, jestli je to liberální.

K Petr: Paní učitelko, to uděláme spolu, stejně tomu nikdo nerozumí.

U: Společně si to potom zkontrolujeme.

D: [(nnn)]

ŽŽ: ((pracují, hledí převážně do učebnic a sešitů nebo jeden na druhého))

K Petr: (nnn) národnostní?

U: No tak národnostní.

K4: Jak to mám jako vědět?

U: ((na K4, u jeho lavice)) Možná je jich tam víc, musíš si to přečíst, abys to věděl. ((odchází od něj, obchází další lavice a ptá se)) Kolik toho máte?

K4: Hmm, tak to stejně nebudu vědět.

K Petr: Jak to mám jako poznat?

ŽŽ: ((pracovní hluk, polohlasné rozhovory, dotazy))

(...)

U: Bud' to opíšete celé, nebo to dokážete zestručnit.

K Petr: To se nedá, přece. To je úkol, co se nedá.

U: Zestručnit - na střední budete muset taky umět zestručňovat.

ŽŽ: Jenomže- [Jenže] Jenomže jsme na základní škole.

K: Když já nevim, co je to to státoprávní, národnostní.

K4: Ale, paní učitelko.

U: A navíc jsem říkala, že test z toho nebude.

K4: Ježišmarjá, tak proč to děláme?

U: Abyste cvičili svoje schopnosti.

K4: Já už je mám tak vycvičený, (1) že už to ani není možný.

Již na začátku hovoří jeden z žáků jako „mluvči“ tř́ídy a dává najevo, že úkolu „nikdo nerozumí'. Navrhuje také, aby žáci úkol vypracovávali společně s učitelkou. Ta místo toho nabízí možnost společně si úkol zkontrolovat (ve skutečnosti 
tedy podle klíče, který ve třídě zná patrně jen ona sama). Na otázku terminologického rázu („Národnostní?“) reaguje pouhým ujištěním, vyzývá k pokračování v plnění bez ohledu na porozumění, kontroluje pouze míru plnění úkolu („Kolik toho máte?"), argumentuje požadavky na styl práce na vyšším stupni školy a cílem „cvičit svoje schopnosti“. Cíl je zřejmě stejně chvályhodný jako v předchozí ukázce - naučit žáky samostatnému myšlení. Méně citlivý př́stup k jejich signálům, menší přístupnost $\mathrm{k}$ průběžné zpětné vazbě však způsobuje, že výsledek se žádoucímu vzdaluje a atmosféra při práci zdaleka nepůsobí suportivně.

\subsubsection{Synergie působení učitele a úsilí žáků jako součást expertní vybavenosti}

Obě ukázky na první pohled odlišuje jev popisovaný jako cirkulace moci (Šed’ová, 2011). V prvním př́ípadě žáci přebírají iniciativu, k čemuž jim učitelka poskytuje četné př́ležitosti. Jejich podněty pak integruje do svého výkladu, jenž se ale díky tomuto postupu stává zdrojem informací k problému, který žáci aktuálně řeší - jejich cíle i cíle učitelky jsou $\mathrm{v}$ dané situaci společné. Ve druhém případě stojí cíle učitelky a žáků ve zřejmém protikladu, žáci vyvíjejí odpor proti zadání (marně) a učitelka vynakládá energii na jeho neutralizaci (rovněž marně).

Identifikace s cíli učitele a ochota žáků „nechat se vtáhnout“ do výukové situace se zjevně odvíjí od způsobu komunikace, je záležitostí procesu předávání informací. „Být se žáky“ (Korthagen et al., 2001, podle Píšová et al., 2013) znamená také sledovat procesy, které se zapojují. Tato schopnost „expertů“ bývá popisována často jako intuitivní a obtížně naučitelná i exaktně uchopitelná. Inspirativním příspěvkem z pohledu experimentálně ukotvené pedagogické psychologie je pojetí J. Kuhla (2000), jenž popisuje společný úkol pedagogů i terapeutů: sledovat úkol jako sekvenci fází, při nichž dominují odlišné emoce i kognitivní systémy. Úkolem toho, kdo proces facilituje, je pomáhat udržet rovnováhu těchto systémů (zaměření na úkol - pamět pro vědomé záměry vs. zaměření na smysl ve vztahu k self - extenzívní pamět, vnímání a intuitivní regulace chování, přecházení mezi pozitivními a negativními emocemi).

Kuhl (2000) popisuje tzv. konativní cyklus, sestávající v plném rozsahu z osmi fází, které vyžadují rozdílné zapojení kognitivních a emočních systémů v různých krocích při plnění náročného úkolu. V psychologii bývají tyto systémy tradičně studovány spiše izolovaně, mnohdy v rámci výzkumu tzv. individuálních rozdílů (např. extraverze, neuroticismus, kognitivní styl). Takový př́stup umožňuje reflektovat individualitu žáka, nap̌r. v globální připravenosti určitým způsobem reagovat. Kuhl však považuje za nezbytné sledovat i dynamiku střídání různých funkcí a regulaci afektů potřebnou napřx při plnění náročného úkolu.

Tradičně můžeme např́klad rozlišovat osoby s vysokou a nízkou mírou neuroticismu. Ve skutečnosti tak ale popisujeme pouze jejich senzitivitu k negativním afektům, připravenost prožívat za určitých okolností negativní emoce; to nám však mnoho neřekne o tom, jak budou reagovat v konkrétní situaci a jak 
ji „nakonec“ vyřeší. I člověk zprvu silně rozrušený se může během krátké doby sám nebo za př́iznivých podmínek se situací vyrovnat stejně příznivě jako jeho „stabilní protějšek. Pedagogickou analogií k posuzování individuálních rozdílů je respektování individuality žáka, analogií k teorii regulace je provázení daného žáka procesem učení a řešení problémů (při respektu $\mathrm{k}$ jeho individuálně specifickým vlastnostem). Dispozice již z definice nejsou něčím, co by se člověk mohl učit; naproti tomu regulace emocí, využívání kognitivních funkcí a volní aspekt motivace představují „učební látku“ předávanou mimo jiné cestou provázení, poskytování vzoru a př́ležitostí k procvičování.

$\mathrm{Na}$ expertnost učitele lze v tomto světle pohlížet také jako na jeho schopnost poskytovat vzor nebo motivačně relevantní materiál. Úkol dobrého učitele je jen zdánlivě jednoduchý - sdělit žákům zadání, mít vliv na způsob řešení a kontrolovat je. Ve skutečnosti se jedná o práci s motivací, která vyžaduje adekvátní reakci v každé z fází procesu výkonové motivace. Velmi subtilní složkou této práce je přecházení mezi podněty $\mathrm{k}$ reprezentaci úkolu, řešení a vlastní osoby žáka. Kuhl (2000) tento proces člení do osmi fází:

1) Vnímání problémů: jedná se o zdánlivě prostý fakt, že žák zaznamená úkol, uvědomí si, že „má co řešit“. Učitel prezentuje úkol jako „motivačně relevantní, jako materiál, který vzbuzuje pozornost, a to svou náročností (ta může spočívat i v „otevřeném konci“), ale i atraktivitou. Tomu odpovídá kombinace spíše negativních emocí (napětí, vnímání nároku) a funkce citlivého vnímání diskrepance mezi potřebnou a dostupnou informací. První z uvedených př́kladů je i př́íkladem „dobře navozené “ problémové situace, ve druhém je diskrepance př́liš velká na to, aby umožnila přechod do dalších fází.

2) Realistické nastavení cílů: pozornost se přesouvá od problému k počátkům jeho řešení, přičemž bez tlumení negativního afektu a aktivace př́stupu k sobě může žák zůstat zahlcen problémem a/nebo si nebude schopen stanovit takové cíle, které odpovídají jeho možnostem - tj. realistické; může se bud' podceňovat a rezignovat, nebo přeceňovat a rezignovat na řešení $z$ opačných důvodů („kašlat na něco"). První prŕḱlad opět obsahuje nápovědy o tlumení negativních afektů (nesprávné odpovědi nejsou kritizovány) a vyvolávání pozitivních (smích). Ve druhém prrípadě přichází pouze zpětná vazba o tom, že cíle nejsou vzhledem ke schopnostem žáků realistické, a žádost o „suplováni“ těchto schopností ze strany učitelky.

3) Vytrvalé úsilí: být „realistický “ také znamená, že si uvědomujeme těžkosti, jež musíme při hledání řešení překonat; znamená tedy obnovit citlivost vưči negativním informacím a odpovídajícím emocím. Na druhou stranu je ale potřeba udržet si povědomí o vlastních záměrech, o „relevanci“ vlastního úsilí $\mathrm{k}$ sobě. Tuto fázi v prvním př́padě reprezentuje vytváření alternativ odpovědí žáky, ve druhém projevy rezignace. 
4) Monitorování znamená jistou ostražitost $\mathrm{k}$ tomu, kdy je správná situace $\mathrm{k}$ určité činnosti (např. přihlásit se, protože něco vím, ale i uklidnit se, protože začínám být ve stresu). Monitorování vyžaduje nejen „vnímat“, ale i vyhodnocovat ve vztahu k sobě a být schopen jednat (tedy redukovat negativní afekty, které jednání brzdí). V prvním příkladu jsou projevem monitorování „konverzačni“ vsuvky typu „a jo“ (dále rozvíjené učitelkou), ve druhém otázky na detaily zadání („Národnostní?"), tentokrát bez odezvy.

Následující tři fáze lze v ukázkách obtížně vzájemně odlišit (Kuhl je popisuje u úkolů náročných a spíše dlouhodobých), jejich dynamika je však v ukázkách patrná.

5) Self-management emocí a motivace: pokud neumíme monitorovat své možnosti, nedaří se nám udržet emoční rovnováhu a přiměřenou úroveň motivovanosti. Projevuje se to např́ílad averzí k náročným úkolům - snažíme se jim vyhýbat, abychom se vyhnuli nepř́ijemným pocitům.

6) Strategické plánování a řešení problémů: vyžaduje opět zaměření na problémy a těžkosti, a tedy frustrační toleranci. Pokud se „pouze“ podaří vzbudit optimismus, vzniká riziko předčasné, málo promyšlené aktivity. V této fázi je třeba umět velmi flexibilně přecházet mezi sebemotivací a relaxací na jedné straně a citlivostí vůči potížím a pozorností vůči jejich povaze na straně druhé.

7) Iniciativa, realizace záměrů: aby se strategické promyšlené plánování propojilo se schopností jednat, plány realizovat, je třeba další povzbuzení pozitivních emocí. Předpokládá se, že promýšlení už proběhlo a že je potřeba najít energii. K tomu může napomoci povzbuzení, „zplnomocnění ze strany učitele. Pomoci může představa odměny nebo odpočinku po plnění úkolu. Pomáhat mủže také kontext, který „facilituje“ jednání - např. to, že spontánně jedná někdo z ostatních nebo že se zapojí skupina jako prostředník sociální facilitace. Je potřeba dát pozor na opačný extrém - spoléhání na známé rutiny (např̀ obsedantní rituály) bez plánování, „akcionistické“ jednání ve smyslu „hlavně rychle, aby to bylo $\mathrm{z}$ krku" apod.

8) Zpětná vazba - pocit úspěchu nebo neúspěchu - je pro jakékoli nové úsilí (vůbec se do něčeho pustit, zlepšovat strategii...) zásadní. Z „kognitivního“ hlediska je optimální, pokud reflexe při získávání zpětné vazby zůstává na úrovni vnímání - nejvíce informací získáme, pokud se vyhneme ukvapenému interpretování nebo hodnocení. Na druhé straně ale potřebujeme pro získání osobní kvality zpětné vazby (např. pocit úspěchu, dobře vykonané práce) zapojení systému reprezentací sebe stejně jako pro generování alternativ po neúspěchu. V prvním prrípadě byla „zpětná vazba“ velmi uměřená a nepřímá, avšak stenizující v duchu přístupu „vaše odpovědi mi umožňují pokračovat ve výkladu“; ve druhém prŕpadě šlo rovněž spíše o nepřímou zpětnou vazbu, avšak negativní (na střední škole také budete muset...) a podrývající relevanci úkolu vůči self (jsou na základní škole, $\mathrm{z}$ učiva nebude test). 


\subsubsection{Shrnutí: Referenční moc jako intuitivní báze moci?}

Referenční moc u našich participantů jsme popsali jako méně reflektovanou bázi moci. Situace praktikantů je specifická např́íklad obavami ze ztráty respektu, malým prostorem i nedostatkem času pro rozvíjení osobních vztahů či tím, že se sami někdy ocitají spíše téměř ve „zkouškové“ situaci.

Patrná je vazba referenční moci k ostatním bázím moci. K legitimní a donucovací bázi moci má referenční moc spíše volnější a negativní vztah. Zřejmě může jít o důsledek úsilí „udržet si autoritu“ nebo naopak kompenzovat nedostatek referenčního vlivu, vztahy jsou ale pouze mírně až středně těsné. V individuálních prŕpadech se setkáváme s různými kombinacemi bází. K odměňovací bázi moci má referenční báze obecně poměrně těsný pozitivní vztah; u obou bází jde o práci s emocemi, získávání si obliby, o schopnosti ocenit - komunikovat spokojenost.

Až překvapivě těsný je vztah referenční a expertní báze moci: v datech od žáků oba aspekty dokonce takřka splývají. Přestože věcně jde nesporně o funkčně odlišné báze, je možné, že zorným úhlem žáků je expertnost učitele patrná až tehdy, je-li provázena aspekty referenční báze moci. Obě báze jsou charakterizovány pozitivním a negativním modem, některé fenomény lze uchopit i jako synergický efekt působení obou bází: takto lze uvažovat například o cirkulaci moci (Šedová, 2011) nebo o kooperativním modu moci expertní (kapitola 4.5.1). Záleží však i na vymezení obou bází: užší pojetí referenční báze založené výhradně na identifikaci a expertní báze $s$ fokusem na učivo uspokojivé vysvětlení vzájemného vztahu neumožňuje; širší pojetí zahrnující motivaci (např. expertnost ve zprostředkování zážitku úspěchu), dynamiku vztahů (např. práce s emocemi při řešení úkolu) a reciprocitu (komunikace, „živá“ spolupráce) se jeví jako přínosnější pro interpretaci zjištěného vztahu, ale i jako potenciálně důležitý podnět pro budování pojetí výuky u (začínajících) učitelů.

Srovnáním různých zdrojů dat však získáváme rozdílný obraz o referenční moci. $\mathrm{V}$ našem výzkumném vzorku je referenční báze moci reflektována více žáky než studenty učitelství. Záznamy interakcí při výuce umožňují identifikovat fenomény, kde se „potkává“ expertnost a referenční povaha interakcí, at již v pozitivním či negativním smyslu. $\mathrm{V}$ rozhovorech však studenti referenční fenomény zmiňují jen sporadicky a navíc nezř́dka v problematických kontextech, jako je udržení hranic a kázně, porušení legitimních pravidel školy, potíže s rozvíjením vztahů na úrovni dobrého osobního kontaktu se žáky, nedostatek prostoru pro neformální kontakt, bezradnost při konfrontaci s osobními problémy žáků... Zdá se, že referenční báze je tedy na jedné straně bází významnou a „efektivní, na druhé straně málo reflektovanou, nebo dokonce jen s rozpaky „př́pustnou“ součástí repertoáru studentů učitelství. V tomto smyslu lze uvažovat o bázi moci „intuitivni“ ve smyslu ponechané mimo rámec systematické př́pravy, ve smyslu jakési „improvizace z nouze“. Termín „intuitivni“ může ale označovat i možnost flexibilnúho, citlivého a přiléhavého reagování jako opozice k rigidním osvojeným vzorcům (viz např. Kuhl, 2000). 
Je možné na základě našich zjištění formulovat doporučení pro praxi? Rozpory mezi obrazem referenční moci z pohledu žáků a studentů učitelství dosti pravděpodobně odrážejí naléhavou potřebu posílit reflexi referenční báze moci na úrovní profesní prrípravy učitelů. Přerod „intuitivního“ jednání ve smyslu nereflektovaného a potenciálně ohrožujícího tápání ve schopnost „intuitivního“ ve smyslu flexibilního sledování dynamických procesů, které ve třídě i u jednotlivých žáků probíhají, je nepochybně nejen záležitostí organizované profesní přípravy, ale i individuálního profesního i osobního růstu. Koncepce, s nimiž ve své kapitole čtenáře seznamujeme, mají sloužit jako připomenutí legitimity tohoto procesu i jako zdroj inspirace při budování takového pojetí výuky, které s působením referenční moci explicitně počítá. 


\title{
5. K DISKUSI: PRVNÍ ZKUŠENOSTI STUDENTU゚ UČITELSTVÍ SE SAMOSTATNOU VÝUKOU
}

\author{
Kateřina Lojdová, Josef Lukas, Tomáš Kohoutek
}

Naši monografii jsme nazvali $Z$ posluchárny za katedru. V názvu se skrývá přechod či přelom, který studenti učitelství absolvují nejen $z$ hlediska prostředí fakulty, které v období praxí „vyměni“ za realitu školní třídy, ale také z hlediska teorie a praxe. Př́prava na fakultě, byt dovednostně orientovaná, nemůže nikdy školní prostředí věrně simulovat (a je také otázkou, zda je to jejím cílem). Teoretická rovina studia se zaměřuje na koncepce, které mohou napomoci studujícím reflektovat realitu působení ve škole a strukturovat vlastní zkušenosti, jde však nezbytně o nabídku limitovaného rozsahu. Rovněž praktická př́prava se ale nevyhnutelně omezuje na určité typy situací, jež si studující promýšlejí a nacvičují. Zkušenosti, získané především $\mathrm{v}$ průběhu praxí, se $\mathrm{s}$ teoretickou poznatkovou základnou propojují ve speciálně zaměřených semináŕích (viz Švec, Pravdová, \& Svojanovský, 2015). V této monografii jsme se také pokusili přispět k propojení teorie a praxe skrze obohacení pedagogické teorie o reálné zkušenosti studentů se samostatnou výukou.

Tyto zkušenosti jsme konceptualizovali jako vyjednávání mocenských bází. Moc chápeme jako uspořádání, které umožňuje změnu a předávání (např. učiva). Nejde však o fenomén jednosměrný (tedy např. uplatňovaný výhradně osobou v roli učitele směrem k žákům), redukovatelný na „autoritu“ ani realizovatelný „pouze“ na základě teoretické znalostní výbavy nebo přenášení dosavadních zkušeností do nové situace. Nastolení či vyjednání určitého mocenského uspořádání je neodmyslitelnou součástí vyučování, která ovlivňuje jeho průběh i výsledky a široce působí na všechny aktéry, tedy především na žáky a vyučující. Není však myslitelné zjednodušovat tento proces do podoby snadno „naučitelného“ algoritmu, a dokonce i motivy k nastavení mocenského uspořádání mohou zůstávat nereflektovány. Je rovněž třeba rozlišovat mezi mocí jako potenciálem, prostou možností určitého uspořádání $\mathrm{v}$ daném kontextu, aktuálním jednáním, jehož cílem je mocenské uspořádání vytvořit, modifikovat nebo posílit, a skutečnými okamžitými nebo dlouhodobými důsledky takového jednání. Přirozená situace počátků působení v roli učitele/učitelky v určité školní třídě zahrnuje celou řadu proměnných, jejichž prostá registrace může být zdrojem poznání a osobního a profesního růstu, ale i zážitku zahlcení a zmatku.

Rovněž výsledky našeho výzkumu jsou ovlivněny řadou faktorů, jejichž kontrola není v našich silách, ale které můžeme kriticky reflektovat. Protože jde 
o značně komplexní problematiku, slouží k tomu jednak kombinace oborové poznatkové základny pedagogiky a psychologie, jednak kombinace různých tradičních výzkumných postupů. Tyto perspektivy se prolínají v rámci jednotlivých tématicky zaměřených kapitol. Zde se zaměřme obecněji na diskusi 1) metodologických možností a limitů našeho výzkumu a 2) specifik vývojové fáze a role, ve které se student učitelství nachází; tyto faktory totiž mohou být pro popsané podoby moci ve školní třídě klíčové.

\subsection{První zkušenosti studentů učitelství se samostatnou výukou v hledáčku kamer}

Zvolený výzkumný design nám umožnil získat komplexní obrázek o zkoumané realitě. Využili jsme smíšeného přístupu na všech úrovních: na úrovni teoretických východisek, designu výzkumu, výzkumných otázek, sběru dat, výběru vzorku, analýzy dat, interpretací dat, prezentací výsledků v textu. Nahlédli jsme na situační dění ve tř́dě skrze pozorování a videozáznam, vnímání tohoto dění studenty učitelství nám zprostředkoval polostrukturovaný hloubkový rozhovor, reflexi tohoto dění i sebe sama studenti zaznamenali v denících. Žákovský pohled pak přinesly dotazníky. Nejedná se přitom o separátní výzkumné metody, nýbrž o komplexní metodologii (srov. Creswell \& Plano Clark, 2011). Jako každý výzkumný design má i takto komplexní sběr dat své výhody a nevýhody z hlediska validity a reliability. Na některá rizika zvoleného výzkumného designu upozorníme.

V knize pracujeme jakoby s oddělenými bázemi moci, nicméně jednotlivé báze moci se většinou uplatňují současně - pouze v různé míře v různých situacích. Elias a Mace (2005) na základě výzkumu bází moci u 325 univerzitních studentů zjistili, že většina bází moci spolu pozitivně koreluje. Legitimní moc je např́ílad výrazně doprovázena mocí donucovací a odměňovací. Pokud by učitel neměl legitimní moc, jeho uplatňování trestů a odměn je obtížně myslitelné.

$\mathrm{Na}$ úrovni analýzy dat $\mathrm{z}$ konkrétních vyučovacích hodin se pak začínaly projevovat určité náznaky typologií v rámci jednotlivých bází moci. Ani jednotlivé typy v rámci pěti bází moci nejsou „čistými typy“. Vždy se do určité míry překrývají a zároveň nejsou vyčerpávajícím obrazem reality, jedná se tedy o ideální typy. Na úrovni analýzy je však možné tyto typy oddělit, což je užitečné pro analýzu výukových situací a hledání specifik začínajících učitelů. Domníváme se, že odhalení specifických aspektů výukových situací u začínajících učitelů může být užitečné pro jejich reflexi v profesní přípravě učitelů.

Ustavování a uspořádání mocenských vztahů ve třídách studentů učitelství je zkoumáno pomocí natáčení ve výuce, což má samozřejmě dopad na uplatňování moci studentem učitelství, žáky i cvičným učitelem, který někdy do výuky studenta učitelství (napřr regulativně do chování žáků) zasahuje (viz kapitoly s výsledky, zejména kapitola 4.2.2). Ukazovalo se, že po čase žáci přestávali kameru 
a kameramana vnímat a podobnou situaci reportovali také studenti učitelství. Nicméně se dá předpokládat, že například vulgarismy a výraznější projevy donucovací moci ze strany studenta učitelství se ve výuce také $\mathrm{z}$ tohoto důvodu neprojevily (srov. Lojdová, 2015). Protiargumentem jsou však výsledky z širšího výzkumu studentů učitelství z adaptace nástroje (viz kapitola 4.1), kde se neukazují rozdíly v průměrné míře uplatňování jednotlivých bází moci zkoumaných osmi studentů učitelství a vzorku 96 studentů učitelství (pilotní výsledky studentů učitelství PdF MU z roku 2014; viz obrázek 5 v kapitole 4.1, s. 61).

$\mathrm{K}$ posunu ve výsledcích $\mathrm{z}$ analýz transkriptů videozáznamů a dotazníků by mohlo docházet také z důvodu efektu senzitivizace a Hawthornského efektu ${ }^{50}$. Tomu jsme předcházeli částečně tak, že studenti učitelství nebyli informováni o výzkumných otázkách (např́ílad podoby donucování a odměňování), ale jen o tom, že výzkum se bude týkat jejich výuky. Žáci a cvičný učitel věděli jen to, že bude zkoumána výuka studenta učitelství. Nicméně i vědomí, že jsou zkoumáni, mohlo mít vliv na výsledky. Dotazník k bázím moci nevyplňovali všichni žáci, ale pouze ti, kteří byli v daný den ve výuce, což je podobné jako u dat $\mathrm{z}$ videonahrávek, kde jsou analyzované výroky a chování také jen u těch žáků, již byli přítomní.

Jakkoli bylo naší snahou přistupovat ke studentům učitelství i k jejich žákům jako k rovnocenným a plnohodnotným původcům informací, je nesporně patrné, že v centru našeho zájmu stáli právě studenti učitelství. Nemusí být dáno jen zvoleným typem školy, že aktivita žáků jako aktérů, podílejících se na nastolování podoby mocenského uspořádání, ustupuje poněkud do pozadí a je v rámci výzkumu a interpretací reflektována méně systematicky než aktivita studentů učitelství.

Vliv na formy vyjednávání a uspořádání mocenských vztahů ve třídě studenta učitelství měl vždy také cvičný učitel. Nezachycujeme tedy prrímo mocenské vztahy, jaké by se vyskytly u začínajícího učitele (v neprítomnosti cvičného učitele). Tato vazba je však detailně popsána v kapitole 4.2 a tvoří přirozené prostředí studentů učitelství na praxích, proto je i zahrnuta v našem designu výzkumu. Studenti učitelství někdy musejí pokračovat ve stylu výuky cvičného učitele či přinejmenším v některých jeho aspektech.

Kromě metodologických otázek se dále budeme věnovat diskusi výsledků výzkumu v kontextu vývojové fáze a sociální role studentů učitelství na praxi.

50 Hawthornský efekt byl zaznamenán a pojmenován v rámci experimentů v továrně Hawthorne u Chicaga ve dvacátých a tř́icátých letech minulého století. Ukázalo se, že participanti ve výzkumu se chovají způsobem, o kterém se domnívají, že je výzkumníky očekáván. Pokud jsou si participanti ve výzkumu vědomi pozorování, pocitují větší důležitost, zlepšují svůj výkon a chování (Landsberger, 1958). 


\subsection{První zkušenosti studentů učitelství se samostatnou výukou v kontextu vývojové fáze a sociální role}

Studenti učitelství v začátcích svých praxí na školách a prvních zkušeností s výukou mají pochopitelně problémy s reflexí a identifikováním projevů svého vystupování v nové roli učitele ve třídách (srov. kapitola 1). Mocenská uspořádání ve vztahu student učitelství - žák, která byla předmětem našeho výzkumu, tak u našich participantů vznikala většinou nezáměrně a intuitivně. Uplatňování moci studenty učitelství jsme v kontextu našeho výzkumu sledovali prostřednictvím pěti mocenských bází (forem moci): legitimní, donucovací, odměňovací, expertní a referenční. Prezentovaná podoba těchto bází je vždy ovlivněna kontextem, v němž se mocenské vztahy mezi studenty učitelství a jejich žáky (včetně vlivu cvičných učitelů) odehrávají. Chceme proto diskutovat výsledky našeho výzkumu v souvislosti s okolnostmi, které mají vliv na způsob uplatňování moci studenty učitelství (viz také kapitola 1 ).

Především musíme brát $\mathrm{v}$ potaz vývojovou fázi profesni kariéry našich participantů a s ní spojené formování jejich identity (učitele). K tomu je nutné mít na zřeteli, že se z hlediska vývojové psychologie studenti učitelství ještě většinou nacházejí v období hledání identity (Erikson, 1999; Macek, 1999) či tzv. vynořující se dospělosti (Arnett, 2012), kdy hledají své místo ve světě, jsou často velmi zaměřeni na sebe (self-focus) či odkládají závazky (commitments) spojované mimo jiné s přijetím profesní identity (podrobněji viz kapitola 1 ). V první kapitole také zmiňujeme pohled na začínající učitele a studenty učitelství jako na ty, kteří se nacházejí ve fázi přežívání ve své nové roli. Jedním z významných prostř̌edků „přežití“ se tak může pro tyto učitele stát právě využívání jednotlivých bází moci.

Ke kázeňskému usměrňování tř́dy, $\mathrm{k}$ němuž studenti učitelství na praxi mohou přistupovat $\mathrm{v}$ represivní podobě, tedy vyskytnou-li se kázeňské problémy, může sloužit legitimní a donucovací moc. Legitimní a donucovací moc má ovšem ve školní tríidě své nezastupitelné místo nejen u začínajících, ale i u zkušených učitelů. Lze uvažovat o vhodných a nevhodných způsobech využití této moci (viz Lojdová \& Lukas, 2015). K analýze legitimní moci jsme přistoupili skrze vstup studenta učitelství do nové role a připsání legitimity člověku, který nepatří do školy. Další naplňování legitimní moci je úzce provázáno s podobami naplňování ostatních bází moci.

Stejně tak mohou studenti učitelství řešit své přežití odměňovací mocí. Nevyzkoušené způsoby odměňování však mohou přivést studenty do „úzkých“ a vyvolat potřebu řešení neočekávané situace s oporou o další báze moci. Zajímavá je také určitá inflace odměn, zejména verbálních, se kterými studenti učitelství ve výuce pracují. Verbální odměna se stává prostředkem řízení třídy spíše než oceněním žáka. 
Na první pohled je kontroverzní otázka expertnosti u začínajících učitelů. Kognitivní schémata začínajících učitelů jsou ve srovnání s učiteli - experty méně elaborovaná a navzájem méně provázaná, $\mathrm{z}$ čehož lze usuzovat, že pedagogické myšlení začínajících učitelů je méně rozvinuto než myšlení učitelů expertů (Janík, 2005). V našem pojetí však chápeme experta jako někoho, kdo dokáže žáky přivést k subjektivně vnímanému úspěchu. To se může podařit i začínajícímu učiteli, který nemá pedagogické myšlení rozvinuté na úrovni experta.

$S$ referenční mocí se objevuje stereotypní pohled na studenta učitelství jako na někoho, kdo je žákovi blíže díky věku. Ukázali jsme, že referenční moc je vícevrstevnatým fenoménem, který všechny báze propojuje, a že věk bližší žákủm nemusí studentům usnadnit fázi přežití. Například vnímání odměn a trestů žáky je podmíněno tím, jaký mají s učitelem vztah. Odměna od učitele, jemuž žák připisuje vysokou referenční moc, bude mít pro něj jinou hodnotu než od učitele, kterému připisuje referenční moc nízkou. Z hlediska definice moci (kapitola 2) se tak bude lišit i míra odměňovací moci učitele, nebot ta je dána tím, jak vnímají moc žáci.

Zajímavý aspekt kombinací jednotlivých bází moci umožňují zachytit výsledky kvantitativního šetření mezi žáky. Interkorelace bází (resp. jejich vyjádření ve strukturálním modelu) lze číst jako strukturu, kde na jedné straně figuruje legitimní a donucovací báze moci, na druhé straně expertní a referenční báze, přičemž odměňovací báze je relativně nezávislá na první dvojici a pozitivně asociovaná s druhou. Jednou z možností výkladu je, že obraz „dobrého učitele“ zahrnuje jeho pojetí jako experta, „člověka na svém místě z hlediska odbornosti i z hlediska lidských kvalit, zatímco „učiteli jako protivníkovi“ je připisována moc ukotvená v legitimních a donucovacích prostředcích vcelku nezávisle na tom, nakolik nastavuje „lepší tváŕc“ (odměňování). Tato struktura provokuje k úvaze o implicitní či explicitní teorii, o niž studenti své působení při nastolování mocenského uspořádání opírají: „behavioristický“ diskurs odměn a trestů na jedné straně a „konstruktivistické“ pojetí výuky na straně druhé. Možná právě zde leží rozdíl odkazující k teoretické výbavě studentů učitelství, k rámcovým, metakognitivním nástrojům uchopení výukové situace pomocí poznatků osvojených v rámci teoretické př́ípravy. Jako faktor utváření vlastního pojetí výuky (Mareš et al., 1996) mohou i tato paradigmata tvořit důležitý aspekt nově osvojované role učitele.

Druhou podstatnou okolností, jež formuje projevy moci u studentů učitelství, jsou samotné podmínky na školách, kde studenti svoje praxe vykonávají. Ve shodě s některými autory (McNally et al., 1997) tedy můžeme uvažovat o vztahových podmínkách (relational conditions), které výuku studentů učitelství na praxích relativně výrazně ovlivňují, protože tvoří socioprofesní rámec jejich vývoje, jenž přesahuje vývojovou fázi, jako je například fáze přežití.

To, že některé hodiny mohou působit dojmem boje o moc mezi žáky a studentem učitelství, nemusí být nutně důsledkem nedostatku pedagogických 
dovedností studenta učitelství, nýbrž se do toho také může promítat klima ve třídě, vztah cvičného učitele $s$ třídou, celkové prostředí školy apod. (Ergens, 2007). I těmito podmínkami jsou podoby moci ve třídách studentů učitelství na praxi rámované. Lze také uvažovat o vlivu témat, cílů a metod jednotlivých vyučovacích hodin v souvislosti s připraveností studentů na konkrétní vyučovací hodinu a na podoby uplatňování moci (např́íklad nezvládnuté téma či př́íprava na výuku se může pojit s nutností většího využívání donucovací moci). Dle longitudinálního šetření Urbánka (2004) realizovaného v letech 1994-2003 hodnotili studenti jako nejobtížnější profesní činnosti: časové rozvržení učiva, hodnocení a klasifikaci a udržení kázně. Tyto obtížné činnosti se mohly promítnout do podob práce $s$ mocí, např́klad v př́padě časové tísně, se kterou se setkali všichni studenti ve výzkumném vzorku, mohlo docházet k větší centralizaci moci v rukou učitele, protože na vyjednávání se žáky jednoduše nezbyl čas.

V kontextu mocenského uspořádání ve školních třídách studentů učitelství lze uvažovat o podílu skutečného vlivu studenta na třídu a vlivu odvozeného od (nepř́mé) moci cvičného učitele a instituce školy. Student učitelství vystupuje v určité dvojroli - disponuje dominantním mocenským statusem vưči žákům, avšak sám se nachází v podřízeném mocenském statusu vůči cvičnému učiteli a př́ípadně i vyučujícím na fakultě (srov. Lojdová, 2014). Studenti učitelství si roli učitele na praxi pouze půjčují a s ní si půjčují i prostředky pro výkon moci. Holvast, Wubbels a Brekelmans (1993) vysvětlují vliv cvičného učitele (v originále cooperative teacher) $\mathrm{z}$ hlediska systémového pojetí následovně: učitel a jeho tř́da mají vytvořen relativně stabilní komunikační systém, takže charakteristiky tohoto systému (i v souvislosti s propůjčenou legitimní mocí) se přenášejí do výuky studentů učitelství - pokud tedy student učitelství „nahrazuje“ v hodinách učitele, který má vybudováno příznivé klima, žáci jsou ochotnější naslouchat studentovi učitelství a plnit jeho instrukce.

Mocenské situace ve školních třídách studentů učitelství jsou tedy specifické těmito charakteristikami, jež však odpovídají realitě prvních zkušeností z výuky, které studenti získávají. Budeme rádi, pokud náš text podnítí a zplnomocní studující k jejich reflexi, stejně jako nás potěší, pokud bude čtenář - profesionál - provokován k dalším interpretacím a hlubšímu konceptuálnímu zpracování nedostatečně reflektovaných fenoménů, které se mohou odrážet v repertoáru učitelského jednání. Také proto si dovolíme knihu netradičně uzavřít dalším konceptem, kterým lze uvažování o moci rámovat - rituály moci. 


\title{
ZÁVĚREM ANEB RITUÁLY MOCI A MOC RITUÁLŮ
}

\author{
Kateřina Lojdová
}

Každá vyučovací hodina v průběhu praxe je studentem učitelství připravována jako premiéra. Obsahuje prvky inscenovanosti a veřejného představení. Tyto znaky jsou charakteristikou rituálu (Kaščák, 2009). Moc jako neviditelný fenomén se zviditelňuje právě v rituálech, které odkrývají performativní charakter učení. Učení se tak zjevuje navenek, je pozorovatelné, prezentované, představované či dokonce stylizované - směrem $k$ pozorovatelům (Kaščák, 2009). Pozorovateli procesu učení jsme byli my, výzkumníci, ale také cviční učitelé a žáci. Všemi těmito aktéry byl výkon studenta učitelství ovlivňován a pro tyto aktéry také adresován.

Metafora divadla není v sociálních vědách nikterak nová. Goffman píše, že „moc jakéhokoli druhu se musí zahalit do účinných prostředků předvádění této moci a bude mít různý účinek v závislosti na tom, jak je dramatizována" (Goffman, 1999, s. 233). Performativita je tedy podmínkou výkonu moci ve školní třídě. Analogie mezi vyučováním a hereckým výkonem se v pedagogických studiích v posledních letech vyskytují, avšak zaměřují se zejména na učitele (srov. Pineau, 1994). Studenti učitelství se doslova učí roli, a toto učení mủžeme chápat i v goffmanovském pojetí: „Jedinec jako účinkující má kapacitu učit se a využívá ji při učení se sociální roli“ (Goffman, 1999, s. 244). Na dění ve školní třídě však $\mathrm{v}$ této publikaci nenahlížíme pouze z perspektivy aktérů, ale i skrze procesy. Zajímá nás, jak se v komunikačních situacích ve školní tř́dě uplatňuje určitý řád. Je to v goffmanovském slova smyslu interakční řád, který je udržovaný díky určitému konsensu a je reprodukován každodenní rutinou, jež je současně jakousi jeho předběžnou zárukou (Šubrt, 2001). Nabízíme proto mikrostudii dění ve školní tř́dě, které v sobě nese fenomén, jenž dění ve školní tř́idě determinuje a zároveň školní třídu překračuje.

Zajímalo nás, jak probíhá proces vyjednávání moci mezi studenty učitelství a jejich žáky ve vyučování, neboli jak se ustavuje mocenská situace ve třídě. Tento proces totiž chápeme jako předpoklad pro naplňování didaktických cílů. Je třeba však dodat, že proces vyjednávání moci je také sám o sobě procesem učení pro všechny zúčastněné aktéry. McLaren (1999) označil školu za repozitář rituálů a tyto rituály hrají kruciální roli ve vztahu k existenci všech aktérů ve škole. McLaren přitom rituály posouvá za tradičně chápané ritualizované chování, jako jsou oslavy, ocenění žáků, pozdrav učitele či hlášení se žáků (srov. Kratochvílová, 2014; Moree, 2013), ale vnímá je jako inherentní součást každé vyučovací hodiny 
a projevů rezistence $\mathrm{k}$ instrukcím učitele. Lze tak hovořit o rituálech legitimní, donucovací, odměňovací, expertní a referenční moci. Chceme-li zobecnit výše uvedené báze moci a jejich projevy, můžeme vlastně hovořit o kulturních kódech školního světa. Jsou jak formální strukturou školní reality, tak i její hloubkovou gramatikou (McLaren, 1999).

Rituály moci lze chápat nejen jako pedagogické prostředky, do jejichž výkonu se studenti učitelství socializují a díky kterým se stávají aktéry reprodukce moci ve škole. Rituály moci totiž mají také funkci stabilizace a reprodukce mocenských vztahů ve společnosti, udržování sociální hierarchie a podpory stereotypního chování na jedné straně, na straně druhé však produkují konflikty a změny ve struktuře společenství (Kaščák, 2009; Obrovská, 2014). Vzdělávání a moc ve společnosti jsou úzce provázané. Apple chápe vzdělávání jako politické bojiště a jako politický akt sám o sobě (Apple, 1996). Zjednodušíme-li chápání moci opomenutím specifičnosti projevů moci v různých sférách lidské činnosti a právně podloženou legitimitou, pak lze tvrdit, že úrovně moci ve společnosti mohou být provázané. Dá se říci, že porozumět vzdělávání znamená porozumět mocenských vztahům ve společnosti a také dominanci a podřízenosti, které tyto vztahy generují a jimiž jsou generovány (Apple, 2013). V perspektivě kritických teorií je moc ústředním konceptem vzdělávání (srov. Freire, 2000; Giroux, 2001; Cho, 2012; McLaren, 1999; Steinberg, 1998). Školní třída je tak platformou, na které se mocenské vztahy zviditelňují, produkují a reprodukují.

Všichni aktéři školní reality se učí výkonu sociálních rolí ve vztahu k normativitě instituce školy a potažmo i k dalším institucím (srov. Lojdová, 2015). Před studentem učitelství stojí škola jako organizace, které se brzy stane reprezentantem, a jejíž normy bude reprodukovat či vůči nim bude revoltovat. Skrze rituály, jež student učitelství přejímá zčásti od svého cvičného učitele a zčásti jako implicitní pravidla školy a školní morálky (viz kapitola 4.2), se stává agentem sociální kontroly a nositelem moci (power-holder). Osvojuje si sociální vnímání školy jako mocného kulturního prostředku zrození nového člověka a jako klíče k sociálnímu úspěchu (Kaščák, 2009).

Výzkumná perspektiva rituálů rekonceptualizuje pohled na proces učení ve škole. $V$ kontextu školního vzdělávání pak nehovoříme o vzdělávání jen jako o předávání vědomostí, dovedností a postojů, ale i jako o socializaci do mocenských rituálů, jež utvářejí spolužití ve škole a spolužití ve společnosti. Pro studenty učitelství je to nová dimenze jejich pregraduální přípravy, kterou vzdělávání na pedagogické fakultě nemůže nabídnout. Až autentické prostředí školy a širšího vztahu se žáky v této instituci zprostředkovává studentům učitelství tuto zkušenost v holistické podobě. Studenti mohou zakusit a reflektovat, že právě neviditelné rituály moci determinují naplňování cílů v didaktickém procesu. Jsou prostředkem nejen vzdělávání, ale i výchovy. Oblast moci ve školní třídě je proto nezbytná k porozumění procesům výchovy a vzdělávání ve škole i k reprodukci moci ve společnosti. 
Výsledky našeho výzkumu tak mohou obohatit kurikulum pregraduální př́ípravy učitelů, a to zejména $\mathrm{v}$ semináŕích věnovaných reflexi studentských výukových praxí, kde mohou studentům pomoci pochopit a vyřešit některé z problémů, do nichž se při práci se tř́dou dostávají. Téma moci ve školní třídě se také může stát součástí kurikula předmětů zaměřených na řízení třídy či na didaktiku.

Nebývá zvykem uzavírat monografii širším, v úvodních teoretických částech dostatečně nepodchyceným konceptem, tedy $\mathrm{v}$ tomto př́padě konceptem rituálů moci. Touto prací se však téma moci ve školní třídě zdaleka nevyčerpalo a naše monografie uvažování o moci ve školní třídě spíše otevírá, než uzavírá. Proto ji ukončujeme pomyslným obráceným trychtýřem, jenž umožní dalším badatelům vydat se i jinými směry, než jsou ty, které jsme zvolili v našem projektu a jejichž výsledky jsme popsali na předchozích stránkách. 


\section{RESUMÉ}

Jednou z největších výzev pro studenty učitelství a začínající učitele je „uřídit tř̌́du“. Schopnost učitele vnímat aktuální stav klimatu třídy a momentální „nastaveni“ jednotlivých žáků je totiž nezbytným předpokladem $\mathrm{k}$ naplňování didaktických cílů, tedy $\mathrm{k}$ tomu, aby učitel mohl ve třídě vůbec vyučovat. $\mathrm{V}$ našem výzkumu jsme se zaměřili na studenty učitelství, kteří v rámci své učitelské praxe garantované pedagogickou fakultou získávají první zkušenosti ze školní reality. Tyto zkušenosti jsme přitom tematizovali konceptem moci ve školní tř́dě. Moc lze charakterizovat jako potenciál ovlivňovat postoje a jednání druhých osob, takže do značné míry představuje jádrovou oblast výukového procesu. Zároveň je fenomén moci reciproční, což znamená, že mocí učitel disponuje jen tehdy, pokud mu ji žáci skutečně připisují. Moc tedy odpovídá interakčnímu charakteru výukového procesu a skrze ni můžeme porozumět tomu, co se mezi učiteli a žáky ve školní třídě odehrává.

Uchopit komplexní fenomén moci jsme se pokusili skrze smíšený výzkumný design. Položili jsme si základní výzkumnou otázku: Jak probíhá proces vyjednávání moci mezi studenty učitelství a jejich žáky ve vyučování na druhém stupni české základni školy v průběhu dlouhodobé pedagogické praxe? Kvalitativní část je postavena na videozáznamech výuky osmi studentů učitelství v průběhu jednoho semestru, na polostrukturovaných rozhovorech s těmito studenty a na denících, které si psali v průběhu praxe. Kvantitativní data vnáší do naší studie výsledky dotazníku Báze moci: verze pro studenty učitelství distribuované žákům v osmi třídách studentů učitelství z našeho výzkumného vzorku.

Studenti v našem vzorku postupně přecházejí z posluchárny za katedru. Součástí tohoto přechodu jsou př́běhy prvních zkušeností s uplatňováním moci ve školní třídě. Přestože se jednotlivé báze moci překrývají, výsledky strukturujeme do př́iběhové linky bází moci. Nejprve popisujeme moc legitimní, jež je ilustrována na vstupu studenta učitelství do nové role učitele. S legitimní moci úzce souvisí moc donucovací, nebot donucování předpokládá legitimitu toho, kdo donucuje. Na donucování nahlížíme skrze její typické projevy ve školní třídě, které lze popsat pomocí relativně ustálených struktur komunikace, takzvaných miniscénářů. Určitým protikladem k donucování je moc odměňovací, jejíž projevy tvoři "druhou stranu stejné mince“. Ukazujeme podoby odměňovací moci a situace odměňování, které mohou být neočekávané i pro studenty učitelství. Moc postavenou na didaktických dovednostech a odborných znalostech odkrývá kapitola věnovaná expertní moci. Poslední empirickou částí je kapitola o moci referenční, jež je postavena na vztahu studenta učitelství se žáky. Navázáním vztahu se žáky, které je dlouhodobým úkolem pro budoucí učitele, naši analýzu př́běhů moci uzavíráme. Výsledky našeho výzkumu diskutujeme v metodologických i teoretických souvislostech a knihu uzavíráme zastřešujícím konceptem rituálů moci. 


\section{SUMMARY}

\section{FROM A LECTURE HALL TO A TEACHER'S DESK Power Relations in Student Teacher Classes}

One of the greatest challenges for student teachers and then for novice teachers is the classroom management. The teacher's ability to perceive the current state of the class climate and the specific setting of individual students is an essential requirement to complete didactic aims in order to be able to teach in the class. Our research was focused on student teachers from Faculty of Education, who have gained one of their first school reality experience in their teaching practice. At the same time, this experience was thematised by the concept of power in a school class. Power can be defined as a potential to affect attitudes and acts of others and as such it presents a core area of the teaching process to a considerable extent. Simultaneously, the phenomenon of power is characterised by its reciprocity, which means that a teacher has the power only when their students really attribute it to them. This is the reason why power responds to the interactive character of the teaching process and taking this into account, the process between teachers and pupils in a class could be better understood.

To deal with this complex phenomenon, a design of mixed methods research was applied. The main research question was: How does a process of power negotiation take place between student teachers and their students in classes in Czech lower secondary schools during their long-term teaching practice? The qualitative part was based on video-studies of eight student teachers' teaching in the course of one semester, on semi-structured interviews with these student teachers, and on reflective diaries that were written by these student teachers during their teaching practice. Quantitative data bring results of the Power Bases: Version for Student Teachers questionnaire into our study. This questionnaire was distributed to the students from eight classes where the student teachers from our research sample were teaching.

The students in our sample gradually proceed from faculty to their teacher's desk in their classrooms. A part of this transition is made by stories of first experience with exercise of power in a school class. Although individual power bases overlap, the findings are structured into a story line of power bases. Firstly, legitimate power is described. This kind of power is illustrated on an entry of a student teacher into their new role of being a teacher. The legitimate power is closely related to coercive power because coercion assumes legitimacy of the individual who coerces. The coercion is viewed through its typical forms in a school class, which can be described with a relatively established communication structures, scenarios, eventually mini-scenarios. A contradiction 
to the coercion is reward power, whose forms make the other side of the coin. Forms of reward power and situations of reward are presented. They happen to be sometimes unexpected by student teachers. The power based on teaching skills and knowledge of the school subject is a focus of the chapter devoted to expert power. The last empirical chapter is a chapter about reference power, which is built on the relationship of a student teacher with their students. Establishing a relationship with students, which is a long-term task for teachers-to-be, concludes our analysis of power stories. The findings of our research are discussed both in methodological and theoretical context and the book is concluded with an overarching concept of power rituals. 


\section{LITERATURA}

Allen, S. (2005). The missing link in alternative certification: Teacher identity formation. Baltimore: University of Maryland, Baltimore County.

Amit, M., \& Fried, M. N. (2005). Authority and authority relations in mathematics education: A view from an 8th grade classroom. Educational Studies in Mathematics, 58(2), 145-168.

Anderson, L. W. \& Krathwohl, D. R. (Eds.) (2001). A Taxonomy for learning, teaching, and assessing - A revision of Bloom's taxonomy of educational objectives. New York: Longman.

Apple, M. W. (1996). Cultural politics and education. New York: Teachers College Press.

Apple, M. W. (2013). Knowledge, power, and education. New York: Routledge.

Arnett, J. J. (1998). Learning to stand alone: The contemporary American transition to adulthood in cultural and historical context. Human Development, 41(5-6), 285-315.

Arnett, J. J. (2000). Emerging adulthood: Theory of development from the late teens through the twenties. American Psychologist, 55(5), 469-480.

Arnett, J. J. (2004). Emerging adulthood: The winding road from the late teens through the twenties. New York: Oxford University Press.

Arnett, J. J. (2012). Adolescence and emerging adulthood. Harlow: Pearson Education.

Arnett, J. J., \& Taber, S. (1994). Adolescence terminable and interminable: When does adolescence end? Journal of Youth and Adolescence, 23(5), 517-537.

Aultman, L. P., Williams-Johnson, M. R., \& Schutz, P. A. (2009). Boundary dilemmas in teacher-student relationships: Struggling with "the line“. Teaching and Teacher Education, 25(5), 636-646.

Barquist Hogelucht, K. S., \& Geist, P. (1997). Discipline in the classroom: Communicative strategies for negotiating order. Western Journal of Communication, 61(1), 1-34.

Bendl, S. (2001). Školní kázeň: Metody a strategie. Praha: ISV.

Bendl, S. (2004). Jak předcházet nekázni aneb kázeňské prostředky. Praha: ISV.

Bergman, M. (2008). Advances in mixed methods research: Theories and applications. Los Angeles: SAGE.

Berne, E. (1997). Co řeknete, až pozdravite: transakční analýza životních scénářu. Praha: Lidové noviny.

Bernstein, B. (1990). Class, codes and control: Volume IV: The structuring of pedagogic discourse. London: Routledge.

Bernstein, B. (1996). Pedagogy, symbolic control and identity. London: Taylor and Francis. 
Bertalanffy, L. (1968). General system theory: Foundations, development, applications. New York: George Braziller.

Blustein, D. L., Phillips, S. D., Jobin-Davis, K., Finkelberg, S. L., \& Roake, A. E. (1997). A theory-building investigation of the school-to-work transition. The Counseling Psychologist, 25, 364-402.

Boulding, K. (1989). Three faces of power. Newbury Park: SAGE.

Bourdieu, P. (1977). Cultural reproduction and social reproduction. In J. Karabel \& A. H. Halsey (Eds.), Power and ideology in education (s. 487-511). NY: Oxford University Press.

Bourdieu, P. (1991). Language and symbolic power. Cambridge: Harvard University Press.

Bradová, J. (2013). Teacher movement trajectories as a predictor of classroom communication processes. Př́spěvek prezentovaný na konferenci Performativity, Materiality and Time, Kodaň.

Braun, V., \& Clarke, V. (2006). Using thematic analysis in psychology. Qualitative Research in Psychology, 3(2), 77-101.

Brekelmans, M., \& Créton, H. (1993). Interpersonal teacher behavior throughout the career. In T. Wubbels \& J. Levy (Eds.), Do you know what you look like? Interpersonal relationships in education (s. 81-102). London: The Falmer Press.

Brewer, J. D., \& Hunter, A. (1989). Multimethod research: A synthesis of styles. Thousand Oaks: SAGE.

Brookfield, S. (2006). The skillful teacher: On technique, trust, and responsiveness in the classroom. San Francisco: Jossey-Bass.

Bryant, J., \& Bates A. (2010). The power of student resistance in action research: Teacher educators respond to classroom challenges. Educational Action Research, 18(3), 305-318.

Buzzelli, C., \& Johnston, B. (2001). Authority, power, and morality in classroom discourse. Teaching and Teacher Education, 17(8), 873-884.

Cangelosi, J. (2006). Strategie ř́zení třídy: jak ziskat a udržet spolupráci žáků při výuce. Praha: Portál.

Clark, R., Livingstone, D., \& Smaller, H. (2012). Teacher learning and power in the knowledge society. Rotterdam: Sense Publishers.

Clegg, S. R., \& Haugaard, M. (Eds.). (2009). The SAGE handbook of power. London: SAGE.

Coates, D. (1991). Power and the state. In D103 Block 4, Politics and power. Society and social science: A foundation course (s. 36-72). Walton Hall: The Open University.

Conway, P. F., \& Clark, C. M. (2003). The journey inward and outward: A re-examination of Fuller's concerns-based model of teacher development. Teaching and Teacher Education, 19(5), 465-482. 
Cook, K. S., \& Emerson, R. M. (1978). Power, equity and commitment in exchange networks. American Sociological Review, 43(5), 721-739.

Cothran, D. J., \& Ennis, C. D. (1997). Students' and teachers' perception of conflict and power. Teaching and Teacher Education, 13(5), 541-553.

Creswell, J. W. (1995). Research design: Qualitative and quantitative approaches. Thousand Oaks: SAGE.

Creswell, J. W., \& Plano Clark, W. L. (2007). Designing and conducting mixed methods research. Thousand Oaks: SAGE.

Creswell, J. W., \& Plano Clark, W. L. (2011). Designing and conducting mixed methods research. Thousand Oaks: SAGE.

Cummins, J. (2009). Pedagogies of choice: Challenging coercive relations of power in classrooms and communities. International Journal of Bilingual Education and Bilingualism, 12(3), 261-271.

Čáp, J., \& Mareš, J. (2001). Psychologie pro učitele. Praha: Portál.

Danaher, G., Schirato, T., \& Webb, J. (2000). Understanding Foucault. London: SAGE.

Day, C. \& Sachs, J. (2005). International handbook on the continuing professional development of teachers. United Kingdom: Open University Press.

Dewey, J. (1936). Rationality in education. The Social Frontier, December, 21(3), 71-73.

Dickar, M. (2008). Corridor cultures: Mapping student resistance at an urban school. New York: NYU Press.

Dreyfus, H. L., \& Dreyfus, S. E. (1986). Mind over machine. New York: The Free Press.

Dvořák, D. (2010). Česká základní škola: víceprípadová studie. Praha: Karolinum.

Dvořák, D., Starý, K., \& Urbánek, P. (2015). Škola v globální době: proměny pěti českých základních škol. Praha: Karolinum.

Elias, S. (2007). Influence in the ivory tower: Examining the appropriate use of social power in the university classroom. Journal of Applied Social Psychology, 37(11), 2532-2548.

Elias, S. M., \& Mace, B. L. (2005). Social power in the classroom: Student power in the classroom: Student attribution for compliance. Journal of Applied Social Psychology, 35(8), 1738-1754.

Ennis, C. D. (1995). Teachers' responses to noncompliant students: The realities and consequences of a negotiated curriculum. Teaching and Teacher Education, 11(5), 445-460.

Ergens, T. (2007). Dominance učitele a způsob jejího vyjadřování. Pedagogika, 27(4), 380-389.

Erchul, W. P., Raven, B. H., \& Ray, A. G. (2001). School psychologists' perceptions of social power bases in teacher consultation. Journal of Educational and Psychological Consultation, 12, 1-23. 
Erchul, W. P., Raven, B. H., \& Whichard, S. M. (2001). School psychologists' and teachers' perceptions of social power bases in school consultation. Journal of School Psychology, 39, 483-497.

Ericsson K. A. (2006). The Influence of experience and deliberate practice on the development of superior expert performance. In K. A. Ericsson, N. Charness, P. J. Feltovich, \& R. R. Hoffman (Eds.), The Cambridge handbook of expertise and expert performance (s. 683-704). New York: Cambridge University Press.

Erikson, E. H. (1999). Životní cyklus rozšírený a dokončený. Praha: Nakladatelství lidové noviny.

Evertson, C., \& Weinstein, C. (2006). Handbook of classroom management: Research, practice, and contemporary issues. Mahwah: Lawrence Erlbaum Associates.

Felix, E. E. (2011). Modern approach to classroom discipline and management: Prevention and intervention strategies for students with behavioral problems. Bloomington: Xlibris Publishing.

Fessler, R. (1995). Dynamics of teacher career stages. In T. R. Guskey \& M. Huberman (Eds.), Professional development in education: New paradigms and practices (s. 171-192). New York: Teachers College Press.

Fessler, R., \& Ingram, R. (2003). The teacher career cycle revisited: New realities, new responses. In B. Davies \& J. West-Burnham (Eds.), Handbook of educational leadership and management (s. 584-590). London: Pearson Education.

Flick, U. (2007). Managing quality in qualitative research. Thousand Oaks: SAGE.

Foucault, M. (1978). The will to knowledge: The history of sexuality. London: Penguin.

Foucault, M. (1980). Power/knowledge: Selected interviews and other writings, 1972-1977. New York: Pantheon Books.

Foucault, M. (2000). Dohližet a trestat: kniha o zrodu vězení. Praha: Dauphin.

Foucault, M. (2005). The body of the condemned. In D. Egan \& L. Chorbajian, Power: A critical reader (s. 25-27). Upper Saddle River: Pearson Prentice Hall.

Franzak, J. K. (2002). Developing a teacher identity: The impact of critical friends practice on the student teacher. English Education, 34(4), 258-280.

Freire, P. (2000). Pedagogy of the oppressed. New York: Continuum.

French, J. R. P., \& Raven, B. (1959). The bases of social power. In D. Cartwright \& A. Zander (Eds.), Group dynamics (s. 259-269). New York: Harper \& Row.

Friesen, M. D., \& Besley, S. C. (2013). Teacher identity development in the first year of teacher education: A developmental and social psychological perspective. Teaching and Teacher Education, 36, 23-32.

Fuller, F. (1969). Concerns of teachers: A developmental characterization. American Educational Research Journal, 6(2), 207-226.

Furlong, J., \& Maynard, T. (1995). Mentoring student teachers: The growth of professional knowledge. London: Routledge. 
Gale, X. (1996). Teachers, discourses, and authority in the postmodern composition classroom. Albany: Sunny Press.

Gavora, P. (2002). Rozhodnutie stat sa učitelom - pohlad kvalitatívneho výskumu. Pedagogická revue, 54(3), 240-256.

Gavora, P. (2005). Učitel a žáci v komunikaci. Brno: Paido.

Giroux, H. (2001). Theory and resistance in education: Towards a pedagogy for the opposition. Westport: Bergin.

Goffman, E. (1999). Všichni hrajeme divadlo. Praha: Nakladatelství studia Ypsilon.

Golish, T. D., \& Olson, L. N. (2000). Students' use of power in the classroom: An investigation of student power, teacher power, and teacher immediacy. Communication Quarterly, 8(3), 293-310.

Gootman, M. (1997). The caring teacher's guide to discipline: Helping young students learn self-control, responsibility, and respect. Thousand Oaks: Corwin.

Gore, J. (1995). On the continuity of power relations in pedagogy. International Studies in Sociology of Education, 5(2),165-188.

Grác, J. (1988). Persuázia: ovplyvňovanie človeka človekom. Martin: Osveta.

Gramsci, A. (2005). Hegemony. In D. Egan \& L. Chorbajian, Power: A critical reader (s. 10-11). Upper Saddle River: Pearson Prentice Hall.

Greene, J. C. (2007). Mixed methods in social inquiry. San Francisco: Wiley \& Sons.

Griffin, R. W., \& Moorhead, G. (2013). Organizational behavior: Managing people and organizations. Mason: South-Western College Publishing.

Hamilton, S. F., \& Hamilton, M. A. (2006). School, work, and emerging adulthood. In J. J. Arnett \& J. L. Tanner (Eds). Emerging adults in America: Coming of age in the 21st century (s. 257-277). Washington, DC: American Psychological Association.

Hammersley, M., \& Woods, P. (Eds). (1984). Life in school: Sociology of pupil culture. Milton Keynes: Open University Press.

Hargreaves, A. (1982). Resistance and relative autonomy theories: Problems of distortion and incoherence in recent Marxist analyses of education. British Journal of Sociology of Education, 3(2), 108-126.

Harrington, A. (2006). Moderní sociální teorie: základní témata a myšlenkové proudy. Praha: Portál.

Hattie, J. (2003). Teachers make a difference: What is the research evidence? (příspěvek na konferenci) In 2003 research conference of the Australian Council for Educational Research - Building teacher quality: What does the research tell us? Melbourne: Australian Council for Educational Research. Dostupné z: http://www.educationalleaders.govt.nz/Pedagogy-and-assessment/Buildingeffective-learning-environments/Teachers-Make-a-Difference-What-is-the-Research-Evidence 
Hawes Denos, C. (2003). Negotiating for positioning of power in a primary classroom. Language Arts, 80(6), 416-424.

Hemmings, A. (2000). The "hidden“ corridor curriculum. The High School Journal, 83(2), 1-10.

Hendrickson, K. A. (2012). Student resistance to schooling: Disconnections with education in rural Appalachia. High School Journal, 95(4), 37-49.

Holt, J. (1984). How children fail. London: Penguin.

Holvast, A., Wubbels, T., \& Brekelmans, M. (1993). Socialization in student teaching. In T. Wubbels \& J. Levy (Eds.), Do you know what you look like? Interpersonal relationships in education (s. 136-145). London: The Falmer Press.

Hrabal, V., \& Pavelková, I. (2010). Jaký jsem učitel. Praha: Portál.

Cho, S. (2012). Critical pedagogy and social change: Critical analysis on the language of possibility. New York: Routledge.

Chong, S., \& Low, E.-L. (2009). Why I want to teach and how I feel about teaching - formation of teacher identity from pre-service to the beginning teacher phase. Educational Research for Policy \& Practice, 8(1), 59-72.

Chong, S., Low, E.-L., \& Goh, K. C. (2011). Emerging professional teacher identity of pre-service teachers. Australian Journal of Teacher Education, 36(8), 50-63.

Ingersoll, R. M. (1996). Teachers' decision-making power and school conflict. Sociology of Education, 69(2), 159-176.

Innes, M. (2003). Understanding social control: deviance, crime and social order. Buckingham: Open University Press.

Jacobs, G. (2012). Models of power and the deletion of participation in a classroom literacy event. Journal of Research in Reading, 35(4), 353-371.

Jacobs, J. E., \& Eccles, J. S. (2000). Parents, task values, and real-life achievement-related choices. In C. Sansone \& J. M. Harackiewicz (Eds.), Intrinsic and extrinsic motivation: The search for optimal motivation and performance (s. 405439). San Diego, CA: Academic Press.

Jacobs, J. E., Davis-Kean, P., Bleeker, M., Eccles, J. S., \& Malanchuk, O. (2005). „I can, but I don't want to": The impact of parents, interests, and activities on gender differences in Math. In A. M. Gallagher \& J. C. Kaufman (Eds.), Gender differences in mathematics: An integrative psychological approach (s. 246-263). New York: Cambridge University Press.

Jamieson, D. W., \& Thomas, K. W. (1974). Power and conflict in the student-teacher relationship. Journal of Applied Behavioral Science, 10(3), 321-336.

Janík, T. (2005). Znalost jako klíčová kategorie učitelského vzdělávání. Brno: Paido. Dostupné z http://www.ped.muni.cz/weduresearch/publikace/pvtp02.pdf

Janík, T., \& Miková, M. (2006). Videostudie: Výzkum výuky založený na analýze videozáznamu. Brno: Paido.

Kahler, T., \& Capers, H. (1974). The Miniscript. Transactional Analysis Journal, $4(1), 26-42$. 
Kaščák, O. (2006). Moc školy: o formatívnej sile organizácie. Trnava: Typi Universitatis Tyrnaviensis.

Kaščák, O. (2008). O moci školy a bezmocnosti dětí. Studia paedagogica, 13(1), $127-140$.

Kaščák, O. (2009). Význam a miesto riuálov v pedagogickej teórii a praxi. Pedagogická orientace, 19(2), 38-52.

Katz, L. G. (1972). The developmental stages of preschool teachers. Elementary School Journal, 73(1), 50-54.

Kearney, P., \& Plax, T. G. (1992). Student resistance to control. In V. P. Richmond \& J. C. McCroskey (Eds.), Power in the classroom: Communication, control, and concern (s. 85-100). New York: Routledge.

Kearney, P., Plax, T. G., Richmond, V. P., \& McCroskey, J. C. (1985). Power in the classroom III: Teacher communication techniques and messages. Communication Education, 34(1), 19-28.

Keller, J., \& Tvrdý, L. (2008). Vzdělanostní společnost? Chrám, výtah a pojištovna. Praha: Sociologické nakladatelství.

Kenkmann, A. (2011). Power and authenticity: Moving from the classroom to the museum. Adult Education Quarterly: A Journal of Research and Theory, 61(3), 279-295.

Kennedy-Lightsey, C. D., \& Myers, S. A. (2009). College students' use of behavioural alteration techniques as a function of aggressive communication. Communication Education, 58(1), 54-73.

Koucký, J., Ryška, R., \& Zelenka, M. (2014). Reflexe vzdělání a uplatnění absolventů vysokých škol. Výsledky šetření REFLEX 2013. Praha: Pedagogická fakulta Univerzity Karlovy v Praze.

Kratochvílová, J. (2014). Rituály v životě jedné školy. Komenský, 139(1), 19-25.

Kremer-Hayon, L., \& Ben-Peretz, M. (1986). Becoming a teacher: The transition from teachers' college to classroom life. International Review of Education, 32(4), 413-422.

Kučera, M. (1995). Commitment a věčné rozpory učitelského povolání. In Stát se učitelem (s. 59-94). Praha: Pedagogická fakulta Univerzity Karlovy v Praze.

Kuhl, J. (2000). The volitional basis of personality systems interaction theory: Applications in learning and treatment contexts. International Journal of Educational Research, 33, 665-703.

Kunnen, E. S., Sappa, V., van Geert, P. L. C., \& Bonica, L. (2008). The shapes of commitment development in emerging adulthood. Journal of Adult Development, 15(3-4), 113-131.

Landsberger, H. (1958). Hawthorne revisited. Ithaca: The New York State School of Industrial and Labor Relations.

Lašek, J. (2004). Nová metoda zjištování klimatu třídy. In J. Lašek (Ed.), Aktuální otázky psychologie učitele (s. 69-75). Hradec Králové: Gaudeamus. 
Lefstein, A., \& Snell, J. (2014). Better than best practice. London: Routledge.

Lent, R. W., Brown, S. D., \& Hackett, G. (1994). Toward a unifying social cognitive theory of career and academic interest, choice, and performance. Journal of Vocational Behavior, 45, 79-122.

Lewis, R. (2001). Classroom discipline and student responsibility: The students' view. Teaching and Teacher Education, 17(3), 307-319.

Lewis, R. (2008). The developmental management approach to classroom behaviour: Responding to individual needs. Camberwell: ACER Press.

Linthicum, R. C. (2006). Building a people of power. Waynesboro, GA: Authentic Press.

Loevinger, J. (1976). Ego development. San Francisco: Jossey-Bass.

Lojdová, K. (2014). „Cítil jsem se jako bachař.“ Reflexe nové sociální role studenty učitelství na praxi. In J. Nehyba, J. Kolář, \& M. Dubec, et al. (Eds.), Reflexe mezi lavicemi a katedrou (s. 87-97). Brno: Masarykova univerzita.

Lojdová, K. (2015). Není nekázeň jako nekázeň: Rezistentní chování žáků jako projev moci ve školní třídě. Orbis scholae, 9(1), 103-117.

Lojdová, K., \& Lukas, J. (2015). Scénáře donucovací moci u studentů učitelství na praxi: studentka Alice. Studia paedagogica, 20(3), 113-130.

Long, R. (1999). 20/20 hindsight: Teacher change and advice. The Internet TESL Journal, 5(11), 1-11. Dostupné z iteslj.org/Articles/Long-TeacherChange.html

Lukas J., \& Švaříček, R. (2007). Reflexe problematiky zkoumání identity učitele. In Svět výchovy a vzdělávání v reflexi současného pedagogického výzkumu. XV. konference České asociace pedagogického výzkumu s mezinárodní účastí pořádaná katedrou pedagogiky a psychologie Pedagogické fakulty JU.

Lukas, J. (2007). Vývoj učitele: přehled relevantních teorií a výzkumů (1. část). Pedagogika, 57(4), 46-60.

Lukas, J. (2008). Vývoj učitele: přehled relevantních teorií a výzkumů (2. část). Pedagogika, 58(1), 36-49.

Macek, P. (1999). Adolescence: psychologické a sociální charakteristiky dospivajících. Praha: Portál.

Macek, P. (2003). Adolescence. Praha: Portál.

Macek, P. (2005). Kde končí dospívání a kde začíná dospělost? In P. Macek \& J. Dalajka (Eds.), Vývoj a utvárení osobnosti v sociálních a etnických kontextech - víceoborový prístup (s. 217-225). Brno: Masarykova univerzita.

Macek, P., Bejček, J., \& Vaníčková, J. (2007). Contemporary Czech emerging adults: Generation growing up in the period of social changes. Journal of Adolescent Research, 22(5), 444-475.

Macek, P., Ježek, S., Lacinová, L., Bouša, O., Kvitkovičová, L., Neužilová Michalčáková, R., \& Širůček, J. (2016). Emerging adults in the Czech Republic: Views into and across different domains of life (s. 175-202). Žukauskienè, R. (Ed.). Emerging adulthood in a European context. New York: Routledge. 
Mainhard, M., Brekelmans, M., \& Wubbels, T. (2011). Coercive and supportive teacher behaviour: Within- and across-lesson associations with the classroom social climate. Learning and Instruction, 21(3), 345-354.

Makovská, Z. (2010). Pojetí moci v žákovských vyprávěních. Studia paedagogica, 15(2), 141-151.

Makovská, Z. (2011). Techniky změny chování a jejich využití ze strany žáků. Pedagogická orientace, 21(1), 85-103.

Malach, J. (2007). Teorie metodiky výchovy. Praha: Univerzita Jana Amose Komenského.

Maňák, J. (2003). Nárys didaktiky. Brno: Masarykova univerzita.

Mareš, J. (2013a). Pedagogická psychologie. Praha: Portál.

Mareš, J. (2013b). Nevhodné chování učitelů k žákům a studentům. Studia paedagogica, 18(1), 7-36.

Mareš, J., \& Beneš, J. (2013). Proměny studia učitelství na pedagogických fakultách v ČR v letech 2000-2012 dané Boloňským procesem. Pedagogika, 63(4), s. $427-450$.

Mareš, J., \& Mareš, J. (2014). Autonomie dospívajícího jedince: složitý proces, nejistý výsledek. Pedagogika, 64(1), 81-98.

Mareš, J., Slavík, J., Svatoš, T., \& Švec, V. (1996). Učitelovo pojetí výuky. Brno: Masarykova Univerzita.

Mareš, J., Vlčková, K., Ježek, S., Lojdová, K., Lukas, J., \& Šalamounová, Z. (2016, $\mathrm{v}$ př́pravě). Báze moci: Manuál k nástroji. Brno: Munipress.

Maslow, A. H. (2014). O psychologii bytí. Praha: Portál.

Mayer, D. (2001). „But that's the thing: Who else is going to teach besides the idealist?" Learning to teach in emotional contexts. In C. Day \& J. Chi-Kin Lee (Eds.), New understandings of teachers work: Emotions and educational change (s. 137-150). New York: Springer.

McCroskey, J. C., \& Richmond, V. P. (1983). Power in the classroom I: Teacher and student perceptions. Communication Education, 32(2), 175-218.

McCroskey, J. C., Richmond, V. P., \& McCroskey, L. L. (2006). An introduction to communication in the classroom: The role of communication in teaching and training. Boston: Allyn \& Bacon.

McLaren, P. (1985). The ritual dimensions of resistance: Clowning and symbolic inversion. Journal of Education, 167(2), 84-97.

McLaren, P. (1999). Schooling as a ritual performance: Toward a political economy of educational symbols and gestures. Lanham: Rowman \& Littlefield Publishers.

McLaren, P. (Ed.). (2006). Rage hope: Interviews with Peter McLaren on war, imperialism, critical pedagogy. New York: P. Lang.

McNally, J., Cope, P., Inglis, W., \& Stronach, I. (1997) The student teacher in school: Conditions for development. Teaching and Teacher Education, 13(5), 485-498. 
Mehan, H. (1979). Learning lessons. Social organisation in the classroom. Cambridge: Harvard University Press.

Merriam, S. (2002). Qualitative research in practice: Examples for discussion and analysis. San Francisco: Jossey-Bass.

Messersmith, E. E., Garrett, J. L., Davis-Kean, P. E., Malanchuk, O., \& Eccles, J. S. (2008). Career development from adolescence through emerging adulthood insights from information technology occupations. Journal of Adolescent Research, 23(2), 206-227.

Middendorf, J., \& McNary, E. (2011). Development of a classroom authority observation rubric. College Teaching, 59(4), 129-134.

Miller, W. L., \& Crabtree, B. F. (1994). Clinical research. In N. K. Denzin \& Y. S. Lincoln (Eds.), Handbook of qualitative research (s. 340-352). Thousand Oaks: SAGE.

Molm, L. (1990). Structure, action, and outcomes: The dynamics of power in social exchange. American Sociological Review, 55(3), 427-447.

Molm, L. (1997). Coercive power in social exchange. New York: Cambridge University Press.

Moree, D. (2013). Učitelé na vlnách transformace: kultura školy před rokem 1989 a po nèm. Praha: Karolinum.

Moscovici, H. (2007). Mirror, mirrors on the wall, who is the most powerful of all? A self-study analysis of power relationships in science methods courses. Journal of Research in Science Teaching, 44(9), 1370-1388.

Nohavová, A. (2012). Výchovný efekt exprese: učit se o tom nebo to zakoušet ve vlastní tvorbě. In J. Mareš (Ed.), Učíme psychologii 2012. Sborník př́spěvků z konference Učime psychologii/Teaching psychology. Brno: Masarykova univerzita.

Novotný, P. (1997). Autoritářství jako jedna z determinant výkonu učitelské profese. Pedagogika, 47(3), 247-258.

Obrovská, J. (2014). Rituály s „těmi druhými“: Perspektiva interakčních rituálů ve školní etnografii etnicky různorodých tř́́dních kolektivů. Sociální studia, 11(2), 51-74.

Oja, S. N. (1990). Developmental theories and the professional development of teachers. Př́íspěvek prezentovaný na výročním setkání American Educational Research Association, Boston.

Ottaway, A., K., C. (1998). Education and society: An introduction to the sociology of education. London: Routledge.

Oyler, C. (1996). Making room for students: Sharing teacher authority in room 104. New York: Teachers College Press.

Pace, J., L., \& Henmmings, A. (2007). Understanding authority in classrooms: A review of theory, ideology, and research. Review of Educational Research, 77(1), 4-27. 
Pace, J., L., \& Hemmings, A. (2006). Classroom authority: Theory, research, and practice. New York: Mahwah.

Pariser, E. (1999). Relational education: An antidote to school-inducted despair. Dostupné z http://www.thecommunityschool.org/relational.htm

Pařizek, V. (1988). Učitel a jeho povolání. Praha: SPN.

Payne, R. (2015). Using rewards and sanctions in the classroom: pupils' perceptions of their own responses to current behaviour management strategies. Educational Review, 67(4), 483-504.

Pietarinen, J., \& Meriläinen, M. (2008). Aktivní a pasivní fáze kariéry učitele v kontextu malotřídní školy. Studia paedagogica, 13(1), 65-83.

Pigge, F. L., \& Marso, R. N. (1997). A seven year longitudinal multi-factor assessment of teaching concerns development through preparation and early years of teaching. Teaching and Teacher Education, 13(2), 225-235.

Pillen, M. T., den Brok, P. J., \& Beijaard, D. (2013). Profiles and change in beginning teachers' professional identity tension. Teaching and Teacher Education, 34, 86-97.

Pineau, E. L. (1994). Teaching is performance: Reconceptualizing a problematic metaphor. American Educational Research Journal, 31(1), 3-25.

Píšová, M., Hanušová, S., Kostková, K., Janíková, V., Najvar, P., \& Tůma, F. (2013). Učitel expert: jeho charakteristiky a determinanty profesního rozvoje (na pozadí výuky cizích jazyků). Brno: Masarykova univerzita.

Pittard, M. M. (2003). Developing identity: The transition from student to teacher. Příspěvek prezentovaný na výročním setkání American Educational Research Association, Chicago.

Pol, M. (2007). Škola v proměnách. Brno: Masarykova univerzita.

Pospíšil, R. (2015, v tisku). Učitelé a řš̌ení kázeňských problémů $v$ základních školách (Disertační práce). Brno: Masarykova univerzita.

Pratto, F., Pearson, A. R., Lee, I., \& Saguy, T. (2008). Power dynamics in an experimental game. Social Justice Research, 21(3), 377-407.

Pravdová, B. (2014). Já jako učitel: profesní sebepojetí studenta učitelství. Brno: Masarykova univerzita.

Pražská skupina školní etnografie (2001). Co se v mládí naučišs. Praha: Pedagogická fakulta Univerzity Karlovy.

Prokop, J. (2005). Škola a společnost v kritických teoriích druhé poloviny 20. století. Praha: Karolinum.

Proweller, A., \& Mitchener, C. P. (2004). Building teacher identity with urban youth: Voices of beginning middle school science teachers in an alternative certification program. Journal of Research in Science Teaching, 41(10), 1044-1062.

Raven, B. H. (1965). Social influence and power. In I. D. Steiner \& M. Fishbein (Eds.), Current studies in social psychology (s. 371-382). New York: Holt, Rinehart \& Winston. 
Raven, B. H. (1992). A power/interaction model of interpersonal influence: French and Raven thirty years later. Journal of Social Behavior and Personality, 7(2), 217-244.

Raven, B. H. (1993). The bases of power: Origins and recent developments. Journal of Social Issues, 49(4), 227-251.

Raven, B. H., Schwarzwald, J., \& Koslowsky, M. (1998). Conceptualizing and measuring a power interaction model of interpersonal influence. Journal of Applied Social Psychology, 28(4), 307-332.

Rigel, M. (2012). Vývoj kázeňských postihů na školách v českých zemích aneb vyhání metla děti z pekla? Komenský, 137(2), 12-16.

Richmond, V. P., \& McCroskey, J. C. (1984). Power in the classroom II: Power and learning. Communication Education, 33(1), 125-136.

Richmond, V. P., \& McCroskey, J. C. (Eds.). (1992). Power in the classroom. Communication, control, and concern. New York: Routledge.

Richmond, V., \& Roach, D. (1992). Power in the classroom: Seminal studies. In V. Richmond \& J. McCroskey (Eds.), Power in the classroom: Communication, control and concern (s. 47-66). New York: Routledge.

Roach, K. D. (1995). Teaching assistant argumentativeness: Effects of affective learning and student perception on power use. Communication Education, 44(1), 15-29.

Roberts, B. W., Caspi, A., \& Moffit, T. E. (2003). Work experiences and personality development in young adulthood. Journal of Personality and Social Psycho$\log y, 84(3), 582-593$.

Rosenthal, R. \& Jacobson, L. (1968). Pygmalion in the classroom: Teacher expectation and pupils' intellectual development. New York: Rinehart \& Winston.

Russell, B. (2004). Power: A new social analysis. New York: Routledge.

Sannino, A. (2010). Teachers' talk of experiencing: conflict, resistance and agency. Teaching and Teacher Education, 26(4), 838-844.

Seidel, T., Prenzel, M., \& Kobarg, M. (Eds.). (2005). How to run a video study: Technical report of the IPN Video Study. Waxmann: Münster.

Senge, P. (2000). The industrial age system of education. In P. Senge (Ed.), Schools that learn (s. 27-58). New York: Doubleday.

Shindler, J. (2010). Transformative classroom management positive strategies to engage all students and promote a psychology of success. San Francisco: Jossey-Bass.

Shkedi, A., \& Laron, D. (2004). Between idealism and pragmatism: A case study of student teachers' pedagogical development. Teaching and Teacher Education, 20(7), 693-711.

Schrodt, P., Witt, P. L, \& Turman, P. D. (2007). Reconsidering the measurement of teacher power use in the college classroom. Communication Education, 56(3), 308-323. 
Schultz, B. D., \& Oyler, C. (2006). We make this road as we walk together: Sharing teacher authority in a social action curriculum project. Curiculum Inquiry, 36(4), 423-451.

Sikes, P. J., Measor, L., \& Woods, P. (1985). Teacher career. Crises and continuities. London: The Falmer Press.

Sinclair, J. M., \& Coulthard, R. M. (1975). Towards an analysis of discourse. Oxford: Oxford University Press.

Skorikov, V. B., \& Vondracek, F. W. (2011). Occupational identity. In S. J. Schwartz, K. Luyckx, \& V. L. Vignoles (Eds.), Handbook of identity theory and research (s. 693-714). New York: Springer.

Smith, C. A., \& Lazarus, R. S. (1990). Emotion and Adaptation. In L. A. Pervin (Ed.), Handbook of personality. Theory and research (s. 607-637). New York: Guilford Press.

Smyth, J. (2006). When students have "relational power": the school as a site for identity formation around engagement and school retention. Dostupné $\mathrm{z}$ http:// www.aare.edu.au/publications-database.php/5245/when-students-have-relational-power-the-school-as-a-site-for-identity-formation-around-engagement-an

Spoelstra, M., \& Pienaar, W. (1999). Negotiation: Theories, strategies and skills. Kenwyn: Juta.

Staton, A. Q. (1992). Teacher and student concern and classroom power and control. In V. Richmond \& J. McCroskey, Power in the classroom (s. 159-176). New Jersey: Lawrence Erlbaum.

Steffy, B. E., et al. (2000). Life cycle of the career teacher. Thousand Oaks: Corwin Press.

Steinberg, S. (1998). Unauthorized methods: Strategies for critical teaching. New York: Routledge.

Strauss, A., \& Corbin, J. (1999). Základy kvalitativního výzkumu. Boskovice: Albert.

Stroot, S., et al. (1998). Peer assistance and review guidebook. Columbus: Ohio Department of Education.

Střelec, S. (1998). Kapitoly z teorie a metodiky výchovy I. Brno: Paido.

Stuchlíková, I. (2013). Strukturované studium učitelství - ano, či ne? Pedagogika, 63(4), 423-426.

Swedberg, R., \& Agevall, O. (2005). The Max Weber dictionary: Key words and central concepts. Stanford: Stanford Social Sciences.

Šalamounová, Z. (2012). Žákovské odpovědi. In K. Šed’ová, R. Švaříček, \& Z. Šalamounová, Komunikace ve školní třídě (s. 75-109). Praha: Portál.

Šalamounová, Z., \& Švaříček, R. (2012). Komunikace z pohledu učitelů. In K. Šedová, R. Švaříček, \& Z. Šalamounová, Komunikace ve školni třídě (s. 215-228). Praha: Portál. 
Šalamounová, Z., Bradová, J., \& Lojdová, K. (2014). Mocenské vztahy mezi začínajícími učiteli a jejich žáky. Pedagogická orientace, 24(3), 375-393.

Šed’ová, K. (2009). Co víme o výukovém dialogu? Studia paedagogica, 14(2), 11-28.

Šed’ová, K. (2013). Humor ve škole. Brno: Munipress.

Šed’ová, K. (2011). Mocenské konstelace ve výukové komunikaci. Studia paedagogica, 16(1), 89-118.

Šedová, K. (2012). Základní charakteristiky výukové komunikace. In K. Šedová, R. Švaříček, \& Z. Šalamounová, Komunikace ve školní třídě (s. 41-52). Praha: Portál.

Šed’ová, K. (2015). Moc v dialogickém vyučování. Pedagogická orientace, 25(1), $32-62$.

Šedová, K. \& Švaříček, R. (2010). Zamlčené hodnocení: zpětná vazba ve výukové komunikaci na druhém stupni základní školy. Studia paedagogica, 15(2), 61-86.

Šed’ová, K., Švaříček, R., \& Šalamounová, Z. (2012). Komunikace ve školní třídě. Praha: Portál.

Štech, S. (1994). Co je to učitelství a lze se mu naučit? Pedagogika 44(4), 310-320. Štech, S., \& Viktorová, I. (1995). Typizační postupy rodičů a učitelů na začátku 2. stupně ZŠ. In Pražská skupina školní etnografie. Typy žáků: Zpráva $z$ terénního výzkumu (s. 49-97). Praha: Pedagogická fakulta Univerzity Karlovy v Praze.

Šubrt, J. (2001). Dramaturgický př́stup Ervinga Goffmana. Sociologický časopis, $37(2), 241-249$.

Švaříček, R. (2011). Funkce učitelských otázek ve výukové komunikaci na druhém stupni základní školy. Studia paedagogica, 16(1), 9-46.

Švaříček, R. (2009). Narativní a sociální konstrukce profesní identity učitele experta (Disertační práce). Dostupné z https://is.muni.cz/auth/th/12302/ ff_d/SVARICEK_Narativni_a_socialni_konstrukce_profesni.pdf

Švaříček, R., \& Šedová, K. (2010). Kvalitativní výzkum v pedagogických vědách. Praha: Portál.

Švec, V., Pravdová, B., \& Svojanovský, P. (2015). Determinanty účinnosti učitelských praxí. Brno: Munipress.

Tashakkori, A., \& Teddlie, C. (2003). Handbook of mixed methods in social \& behavioral research. Thousand Oaks: SAGE.

Torff, B. (2003). Developmental changes in teachers use of higher order thinking and content knowledge. Journal of Educational Psychology, 95(3), 563-569.

Urbánek, P. (2004). Sebehodnocení profesních činností studenty učitelství (Analýza longitudinálního šetření). In J. Škoda \& P. Doulík (Eds.), Profese učitele a současná společnost. Ústí nad Labem: PdF UJEP v Ústí nad Labem.

Vališová, A. (1998). Autorita jako pedagogický problém. Praha: Karolinum. 
Vališová, A., \& Kasíková, H. (2011). Pedagogika pro učitele. Praha: Grada. van Huizen, P. H. (2000). Becoming a teacher. Development of a professional identity by prospective teachers in the context of university-based teacher education (Disertační práce). Utrecht: Universiteit Utrecht.

Veenman, S. (1987). On becoming a teacher: An analysis of initial training. Př́spěvek prezentovaný na konferenci Conference on Education of the World Rasque Congress, Bilbao.

Viktorová, I. (1995). Studenti pedagogické fakulty k profesi učitele. In Stát se učitelem (s. 95-117). Praha: Pedagogická fakulta Univerzity Karlovy v Praze.

Viktorová, I. (2011). Mimořádné události v komunikaci rodiny a školy, Studia paedagogica, 16(2), 27-47.

Vlčková, K., Mareš, J., \& Ježek, S. (2015, v tisku). Adaptation of teacher power use scale to lower secondary students and student teachers. Pedagogická orientace, 25(6).

Vlčková, K., Mareš, J., Ježek, S., \& Z. Šalamounová (2016, v př́ipravě). Báze moci používané učitelem ve školní třídě: česká adaptace dotazníku Teacher Power Use Scale. Pedagogika.

Walkington, J. (2005). Becoming a teacher: encouraging development of teacher identity through reflective practice. Asia-Pacific Journal of Teacher Education, 33(1), 53-64.

Watzlawick, P., Bavelas, J. B., \& Jackson, D. D. (1999). Pragmatika lidské komunikace. Hradec Králové: Konfrontace.

Weber, M. (1998). Metodologie, sociologie a politika. Praha: M. Havelka.

Weidman, J. C. (2006). Socialization of students in higher education: Building on and extending lines of inquiry for the advancement of the public good. In C. F. Conrad \& R. C. Serlin, The SAGE handbook for research in education (s. 253-262). Thousand Oaks: SAGE.

Weller, L. D., \& Weller, J. S. (2002). The assistant principal: Essentials for effective school leadership. Thousand Oaks: Corwin Press.

Whiston, S. C., \& Keller, B. K. (2004). The influences of the family of origin on career development: A review and analysis. The Counseling Psychologist, 32, 493-568.

Willis, P. (1977). Learning to labor: How working class kids get working class jobs. New York: Columbia University Press.

Winograd, K. (2002). The negotiative dimension of teaching: Teachers sharing power with the less powerful. Teaching and Teacher Education, 18(3), 343-362. Wolcott, H. F. (2008). Ethnography: A way of seeing. Lanham: AltaMira Press.

Woods, P. (1979). The divided school. London: Routledge.

Woods, P. (1983). Sociology and the school. An interactionist viewpoint. London: Routledge.

Woods, P. (1994). Adaptation and self-determination in English primary school. Oxford Review of Education, 20(4), 387-410. 
Wróbel, A. (2008). Výchova a manipulace. Praha: Grada.

Wubbels, T., \& Levy, J. (Eds.). (1993). Do you know what you look like? Interpersonal relationships in education. London: The Falmer Press.

Wubbels, T., et al. (1993). The model for interpersonal teacher behavior. In T. Wubbels \& J. Levy (Eds.), Do you know what you look like? Interpersonal relationships in education (s. 13-28). London: The Falmer Press. 


\title{
PŘÍLOHY
}

\section{Příloha 1. Dotazník Báze moci: verze pro studenty učitelství}

Jedná se o verzi pro studentku učitelství (ženu) před konfirmační faktorovou analýzou administrovanou ve výzkumu prezentovaném v knize. Administrována byla i verze pro studenty učitelství - muže.

\begin{abstract}
Ahoj,
zajímá nás, jak to funguje u vás ve tř́idě, když vás učí paní učitelka ........, která je u vás ve škole na praxi. Chtěli bychom tě proto požádat o vyplnění krátkého dotazníku. Zabere to asi 15 minut. Odpovědi prosím piš sám/sama za sebe - zajímá nás totiž, jak to vidíš ty. Nejsou správné nebo špatné odpovědi. Dotazník je anonymní, takže nikdo nebude vědět, jak jsi odpovídal/a. Odpověz prosím na všechny otázky.
\end{abstract}

Zakroužkuj, nebo vyplň:

\begin{tabular}{|c|c|c|}
\hline Jsem holka / kluk. & Je mi ........... let. & Dnes se cítím $:-;:)$ \\
\hline
\end{tabular}

U každé otázky udělej JEDEN křížek do políčka, podle toho, jak moc souhlasíš, nebo nesouhlasíš.

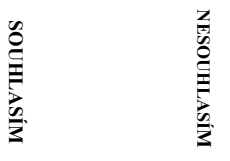

Zkus si odpovídání na cvičném př́kladu:

$0 \quad$ Mám rád prázdniny.

\section{PŘI ODPOVÍDÁNÍ MYSLI NA PANÍ UČITELKU, KTERÁ JE U VÁS VE ŠKOLE NA PRAXI A} UČILA TĚ ČESKÝ JAZYK A LITERATURU.

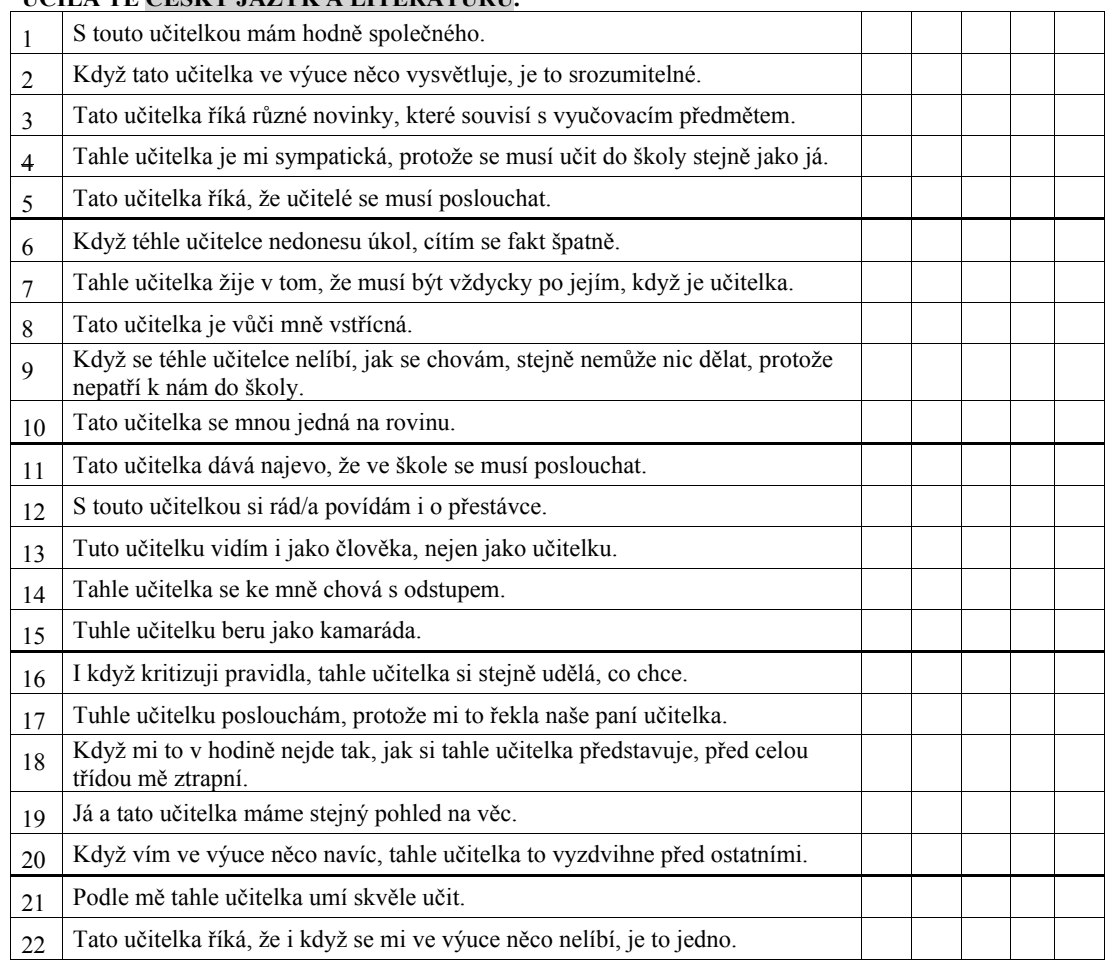




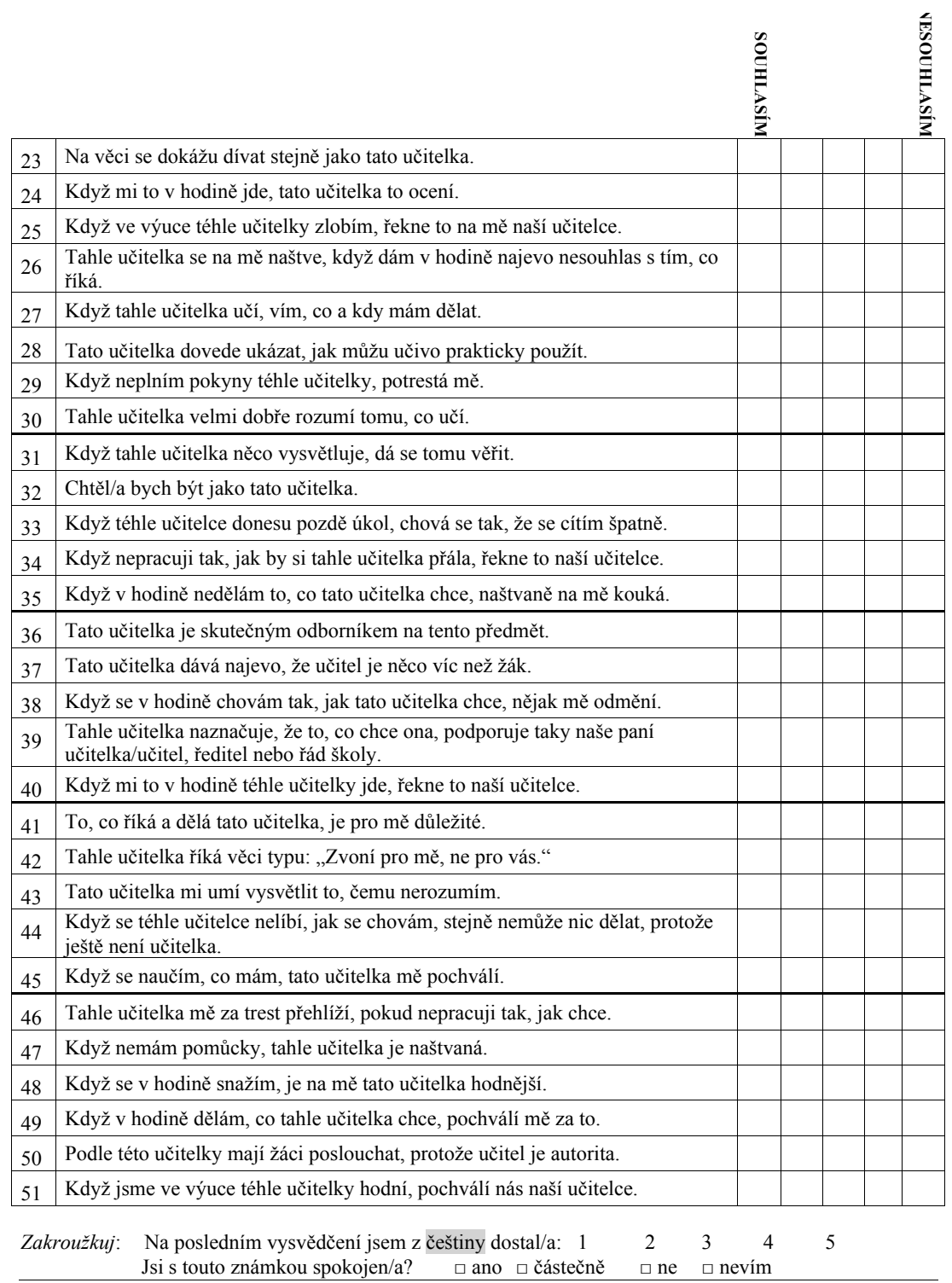

Tady můžeš napsat, co bys chtěl/a ještě $\mathrm{k}$ dotazníku dodat.

Zkontroluj prosím, jestli jsi odpověděl/a na všechny otázky. Moc ti děkujeme za spolupráci! 


\section{Přiřazení položek k bázím moci studenta učitelství ${ }^{51}$}

\section{Expertní moc}

E02: Když tato učitelka ve výuce něco vysvětluje, je to srozumitelné.

E03: Tato učitelka říká různé novinky, které souvisí s vyučovacím předmětem.

E21: Podle mě tahle učitelka umí skvěle učit.

E27: Když tahle učitelka učí, vím, co a kdy mám dělat.

E28: Tato učitelka dovede ukázat, jak můžu učivo prakticky použít.

E30: Tahle učitelka velmi dobře rozumí tomu, co učí.

E31: Když tahle učitelka něco vysvětluje, dá se tomu věřit.

E36: Tato učitelka je skutečným odborníkem na tento předmět.

E43: Tato učitelka mi umí vysvětlit to, čemu nerozumím.

\section{Legitimní/donucovací moc}

L05: Tato učitelka ř́ká, že učitelé se musejí poslouchat.

L07: Tahle učitelka žije v tom, že musí být vždycky po jejím, když je učitelka.

L09: Když se téhle učitelce nelíbí, jak se chovám, stejně nemůže nic dělat, protože nepatří k nám do školy.

Ł11: Tato učitelka dává najevo, že ve škole se musí postouchat.

(L14: Tahle učitelka se ke mně chová s odstupem.)

(L17: Tuhle učitelku poslouchám, protože mi to řekla naše paní učitelka.)

(L22: Tato učitelka říká, že i když se mi ve výuce něco nelíbí, je to jedno.)

L37: Tato učitelka dává najevo, že učitel je něco víc než žák.

(L39: Tahle učitelka naznačuje, že to, co chce ona, podporuje taky naše paní učitelka/učitel, ředitel nebo řád školy.)

L42: Tahle učitelka říká věci typu: „Zvoní pro mě, ne pro vás.“

L44: Když se téhle učitelce nelíbí, jak se chovám, stejně nemůže nic dělat, protože ještě není učitelka.

(L50: Podle této učitelky mají žáci poslouchat, protože učitel je autorita.)

Đ06: Když téhle učitelce nedonesu úkol, cítím se fakt špatně.

D16: I když kritizuji pravidla, tahle učitelka si stejně udělá, co chce.

D18: Když mi to v hodině nejde tak, jak si tahle učitelka představuje, před celou třídou mě ztrapní.

(D25: Když ve výuce téhle učitelky zlobím, řekne to na mě naší učitelce.)

D26: Tahle učitelka se na mě naštve, když dám v hodině najevo nesouhlas s tím, co ř́íká.

(D29: Když neplním pokyny téhle učitelky, potrestá mě.)

D33: Když téhle učitelce donesu pozdě úkol, chová se tak, že se cítím špatně.

D34: Když nepracuji tak, jak by si tahle učitelka přála, řekne to naší učitelce.

51 Přeškrtnuté položky byly vyřazeny $\mathrm{z}$ výpočtů $\mathrm{v}$ této knize na základě výsledků konfirmační faktorové analýzy. Položky v závorkách jsme vyřadily z druhé, zkrácené verze nástroje na základě faktorových nábojů a analýzy reliability. Zkrácenou verzi nástroje v současnosti ověřujeme. 
D35: Když v hodině nedělám to, co tato učitelka chce, naštvaně na mě kouká.

D46: Tahle učitelka mě za trest přehlíží, pokud nepracuji tak, jak chce.

D47: Když nemám pomůcky, tahle učitelka je naštvaná.

\section{Odměňovací moc}

O20: Když vím ve výuce něco navíc, tahle učitelka to vyzdvihne před ostatními.

$\mathrm{O} 24$ : Když mi to v hodině jde, tato učitelka to ocení.

O38: Když se v hodině chovám tak, jak tato učitelka chce, nějak mě odmění.

O40: Když mi to v hodině téhle učitelky jde, řekne to naší učitelce.

O45: Když se naučím, co mám, tato učitelka mě pochválí.

O48: Když se v hodině snažím, je na mě tato učitelka hodněǰ̌í.

O49: Když v hodině dělám, co tahle učitelka chce, pochválí mě za to.

O51: Když jsme ve výuce téhle učitelky hodní, pochválí nás naší učitelce.

\section{Referenční moc}

R01: S touto učitelkou mám hodně společného.

R04: Tahle učitelka je mi sympatická, protože se musí učit do školy stejně jako já.

(R08: Tato učitelka je vůči mně vstřícná.)

R10: Tato učitelka se mnou jedná na rovinu.

R12: S touto učitelkou si rád/a povídám i o přestávce.

R13: Tuto učitelku vidím i jako člověka, nejen jako učitelku.

R15: Tuhle učitelku beru jako kamaráda.

R19: Já a tato učitelka máme stejný pohled na věc.

R23: Na věci se dokážu dívat stejně jako tato učitelka.

R32: Chtěl/a bych být jako tato učitelka.

R41: To, co ř́́ká a dělá tato učitelka, je pro mě důležité. 


\section{Př́loha 2. Dotazník Báze moci: verze pro učitele}

Verze dotazníku administrovaná ve výzkumu $\mathrm{k}$ adaptaci nástroje, před realizací konfirmační faktorové analýzy. Jedná se o verzi pro ženu učitelku, k dispozici je i verze pro muže a také zkrácená verze vytvořená na základě pilotáže (Mareš et al., 2016, v př́ípravě; Vlčková, Mareš, Ježek, \& Šalamounová, 2016, v př́ípravě).

Ahoj,

zajímá nás, jak to funguje ve vaší trrídě. Odpovědi piš sám za sebe, jak to vidíš ty. Nejsou správné nebo špatné odpovědi. Dotazník je anonymní. Vyplnění trvá asi 15 minut. Odpověz prosím na všechny otázky.

Zakroužkuj nebo vyplň:

\begin{tabular}{|l|l|l|}
\hline Jsem holka/kluk. & Je mi ........... let. & Dnes se cítím $:(-) ;$ \\
\hline
\end{tabular}

U každé otázky udělej JEDEN křižek do políčka, podle toho, jak moc souhlasíš nebo nesouhlasíš.

Vyplň cvičný př́iklad:

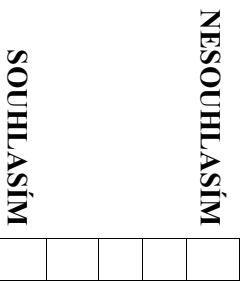

Při odpovídání mysli na paní učitelku, kterou máš z předmětu:

\begin{tabular}{|l|l|l|l|l|l|}
\hline 1 & S touto učitelkou mám hodně společného. & & & & \\
\hline 2 & Když tato učitelka ve výuce něco vysvětluje, je to srozumitelné. & & & \\
\hline 3 & $\begin{array}{l}\text { Tato učitelka říká různé novinky, které souvisí s jejím vyučovacím } \\
\text { předmětem. }\end{array}$ & & & & \\
\hline 4 & Tato učitelka vysvětluje učivo podle toho, kolik toho vím. & & & \\
\hline 5 & Moje učitelka říká, že učitelé se musí poslouchat. & & & \\
\hline 6 & Když nedonesu úkol, cítím se fakt špatně. & & & \\
\hline 7 & $\begin{array}{l}\text { Myslím si, že tahle učitelka žije v tom, že musí být vždycky po jejím, když je } \\
\text { učitelka. }\end{array}$ & & & & \\
\hline 8 & Tato učitelka je vůči mně vstřícná. & & & \\
\hline 9 & Myslím si, že moje učitelka se mnou jedná na rovinu. & & & \\
\hline 10 & Tato učitelka dává najevo, že ve škole se musí poslouchat. & & & \\
\hline 11 & Rád si s učitelkou povídám i o přestávce. & & & \\
\hline 12 & Tuto učitelku vidím i jako člověka, nejen jako učitelku. & & & \\
\hline 13 & Myslím si, že tahle učitelka se ke mně chová s odstupem. & & & \\
\hline 14 & Tuhle učitelku beru jako kamaráda. & & & & \\
\hline 15 & I když kritizuji pravidla, učitelka si stejně udělá, co chce. & & & \\
\hline 16 & $\begin{array}{l}\text { Když mi to v hodině nejde tak, jak si učitelka představuje, před celou třídou } \\
\text { mě ztrapní. }\end{array}$ & & & & \\
\hline 17 & Myslím si, že já a moje učitelka máme stejný pohled na věc. & & & \\
\hline 18 & Když vím ve výuce něco navíc, moje učitelka to vyzdvihne před ostatními. & & & \\
\hline
\end{tabular}




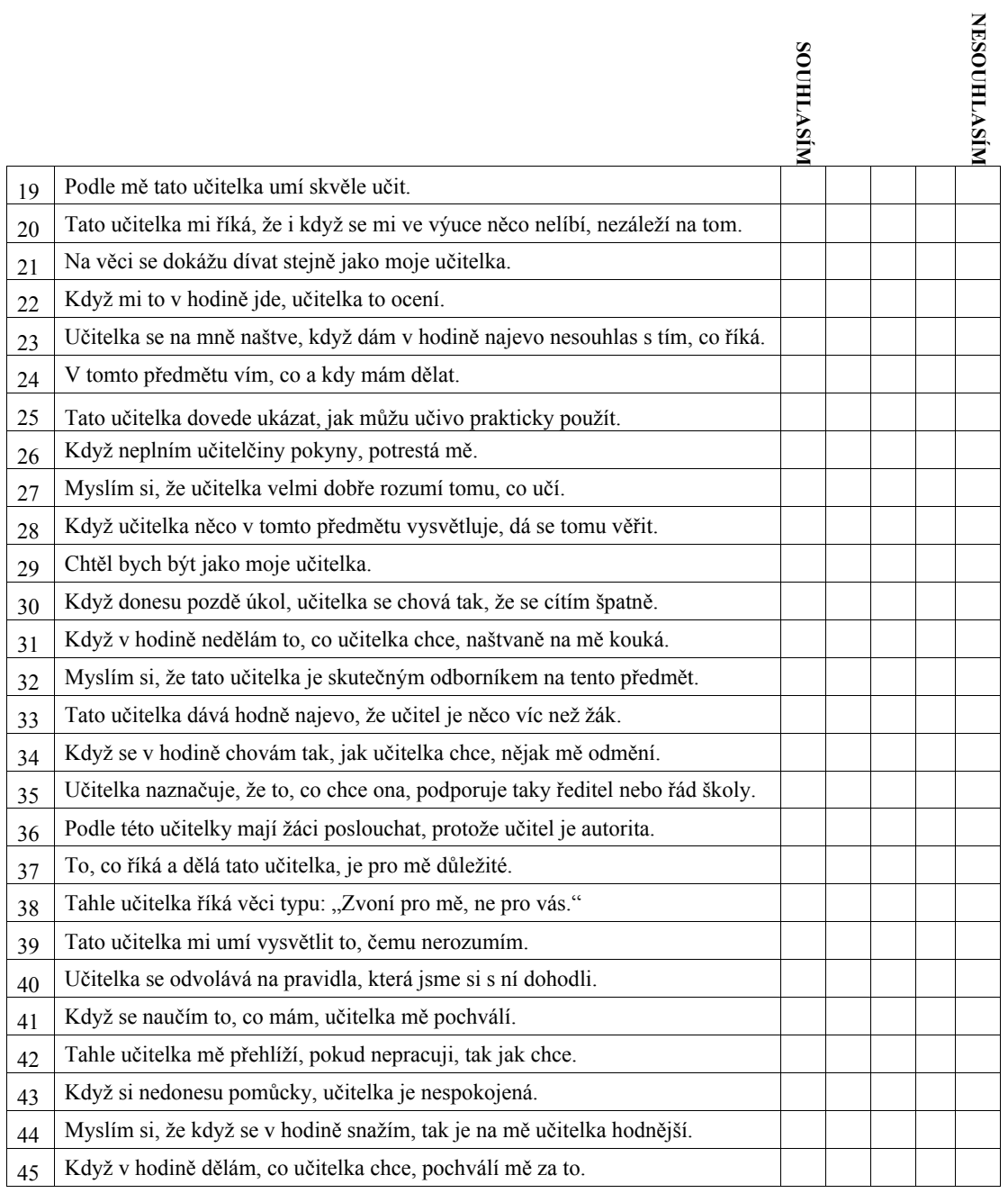

Zakroužkuj: Na posledním vysvědčení jsem měl/a z tohoto předmětu známku: $\begin{array}{llllll}1 & 2 & 3 & 4 & 5\end{array}$

Jsi s touto známkou spokojen/a? $\square$ ano $\quad \square$ částečně $\square$ ne $\square$ nevím

Tady můžeš napsat, co bys chtěl/a ještě $\mathrm{k}$ dotazníku dodat:

Zkontroluj prosím, jestli jsi odpověděl/a na všechny otázky. Děkujeme za spolupráci. 


\section{Př́loha 3. Tazatelské schéma polostrukturovaného rozhovoru ${ }^{52}$}

HVO) Jak studenti učitelství vnímají ustavování mocenského uspořádání ve třídě, v níž realizují svoji praxi?

1. Proč jste se stal/a učitelem/kou?

SVO1) Jak studenti učitelství vnímají vstup do třídy, v níž realizují svoji praxi?

1. Jak vypadala první hodina?

2. Jak jste se žákům představil/a?

3. Jací jsou žáci v téhle třídě?

4. Stalo se během první hodiny něco, co Vás překvapilo?

5. Jak by se podle Vás měl učitel připravit na první den? Na co by si měl dát pozor?

6. Jak jste se po první hodině v této třídě cítil/a?

7. Jak na Vás působí nová škola?

8. Jak jste se ve škole zabydlel/a?

SVO2) Jak studenti učitelství vnímají své působení při ustavování mocenského uspořádání ve tř́iě, v níž realizují svoji praxi?

1. Jak žáky oslovujete?

2. Co děláte, když potřebujete získat pozornost žáků?

3. Co děláte, když se žáci tváří znuděně?

4. Máte nějaké finty, kterými žáky získáváte na svou stranu?

5. Co děláte, když potřebujete žáky rozmluvit?

6. Jakým způsobem vyvoláváte žáky?

7. Máte nějaká pravidla, která chcete, aby žáci dodržovali?

8. Jak tato pravidla vznikala?

9. Jakým způsobem se o nich žáci dozvídají? (ptát se po jednotlivých pravidlech, kde to bude vhodné)

10 . V jakých situacích je zásadní, aby o věcech rozhodl výhradně učitel?

11. Kdy se ve třídě cítíte „pevný/á v kramflecích“? Můžete tuto situaci popsat?

12. Stalo se Vám, že jste měl/a pocit, že třídu nemáte pod kontrolou? Můžete tuto situaci popsat?

13. Používáte ve tř́dě humor? Kdy a k čemu? / Stalo se Vám, že jste se se žáky ve tř́dě společně zasmáli?

14. Doprovázel/a jste žáky na exkurzi? Jak se proměnil způsob práce v této výukové situaci?

15. Jak se proměnil způsob práce při řešení kázeňských problémů, návštěvě cizí osoby ve třídě... 
16. Jak se na výuku připravujete?

17. Vnímáte se jako odborníka?

18. Stalo se Vám, že jste si nebyl/a jistý/á učivem?

19. Stalo se Vám, že se Vás žáci zeptali na něco, co jste nevěděl/a?

SVO3) Jak studenti učitelství vnímají postupy a strategie, jimiž do mocenského uspořádání vstupují jejich žáci?

1. Mohou se žáci podílet na rozhodování o tom, jaké aktivity budete ve třídě dělat?

2. Mohou se žáci podílet na rozhodování o tom, jak budou aktivity probíhat?

3. Mohou se žáci podílet na rozhodování o tom, jak se budou aktivity ve třídě hodnotit?

4. Mají možnost žáci rozhodovat o činnostech ve třídě? Jak takový proces vypadá a jak do něj zasahujete?

5. Máte ve třídě žáka, který chce mít konečné slovo? Jak s ním pracujete?

6. Stane se Vám, že žáci nedodrží pravidlo XX? (zde reagovat na všechna pravidla, která zazněla)

7. Jak to probíhá?

8. Jak na to reagujete? (opakují se)

9. Stalo se vám, že měli žáci „navrch“? Proč k tomu došlo? Jak jste to řešil/a?

SVO4) Jak studenti učitelství vnímají působení školy na mocenské uspořádání ve třídě?

1. Jak se cítíte v kolektivu učitelů na této škole?

2. Mluvíte s některými z učitelů o situacích ve třídě? Kdy? O jakých?

3. Jak spolupracujete s učitelem, který Vás má na starost?

4. Seznámil/a jste se s ředitelem školy? Co jste se od něj o škole dozvěděl/a?

5. Četl/a jste školní řád? (Je k něčemu užitečný? Pracujete s ním?)

6. Dovedete si představit, že byste tady v budoucnu působil/a jako učitel/ka?

1. Naučila Vás praxe v této třídě doposud něco nového? 


\section{Př́loha 4. Manuál pro transkripci videodat a audiodat ${ }^{53}$}

Cílem transkriptu je vytvořit komplexnější záznam vyučovací hodiny, jehož pročtení umožní rekonstruovat co nejvěrohodnější obraz pozorovaného. Transkript by měl obsahovat kompletní verbální komunikaci, neverbální komunikaci a veškeré důležité dění ve tř́ídě.

Uvedené údaje se týkají primárně přepisů videí. U přepisů rozhovorů nebude celá škála značek či označení účastníků využita, což vyplývá z povahy dat.

\section{Transkripční značky}

\begin{tabular}{|c|c|}
\hline $\mathrm{xt}$ & - verbální stopa \\
\hline (text) & - pravděpodobná verbální stopa \\
\hline (nnn) & - nerozeznatelná verbální stopa \\
\hline (.) & - krátká pauza (pod jednu vteřinu) \\
\hline (1) & - delší pauza (číslovka označuje délku pauzy ve vteřinách) \\
\hline$)$ & - popis prosodie nebo neverbální aktivity (šepot, smích, ticho ad.) \\
\hline tevt & $\begin{array}{l}\text { - překrývající se verbální stopa či akce; umístění na řádku ve vztahu } \\
\text { k předchozímu řádku značí, kde došlo k překryvu }\end{array}$ \\
\hline & - nedořečené slovo \\
\hline & - důraz na verbální stopu (na slabiku, slovo či sousloví) \\
\hline $\mathrm{T}$ & - nadprůměrné zvýšení hlasitosti, zvolání, křik \\
\hline & - časová lokace transkriptu (od zvonění vždy po pěti minutách) \\
\hline
\end{tabular}

\section{Označení účastníků komunikace}

U: $\quad$ - učitel/ka

Kamila: - konkrétní žákyně

D: $\quad$ - žákyně, u níž nelze určit, o koho se jedná

K: $\quad$ - žák, u kterého nelze určit, o koho se jedná

ŽZ̆: $\quad$ - skupina žáků

CU: $\quad$ - cvičný učitel

T: $\quad-$ tazatel

53 Sestaven Zuzanou Šalamounovou v roce 2013. 


\section{Formální náležitosti}

1) Každý transkript je uveden hlavičkou se základními informacemi o transkribovaném souboru a o aktuální situaci ve třídě.

2) Na konci každého transkriptu videonahrávky je obsaženo schéma třídy se jmény žáků, kteří sedí na jednotlivých místech a vyznačení neobsazených míst.

3) Každý transkript je psán fontem Times New Roman, velikostí písma 12, rádkováním 1,5, bez odsazení, se zarovnáním do bloku. Soubor může být uložen bud' ve formátu doc, docx, nebo rtf.

\section{Příklad}

Participantka: Učitelka Hana, video 1

Datum: 17. 1. 2014, pátek

Tř́́da: 7. A

Literatura, třetí vyučovací hodina (od 10 hod.)

Ve třídě je přítomno 24 žáků, 12 dívek a 12 kluků. Žáci před zvoněním poměrně tiše sedí v lavicích, většina $\mathrm{z}$ nich se dívá do sešitů a opakuje si. Pouze v předních lavicích u dveři si skupina dívek povídá a směje se.

\section{(...)}

10 - 15 min.

U: A my budeme (.), nadpis si tam dejte tedy ((ukazuje na tabuli na nadpis)), zase nezapomeneme na datum, dvojčlenné věty.

((12 - žáci zapisují, jakmile mají, dívají se na $U))$

U: Co si představujete pod pojmem dvojčlenné věty? (2) Co to budou dvojčlenné, dvojčlenné věty? Máme to v názvu.

ŽŽ: $((\check{s} u m))$

Kamila a Dana: ((přihlásí se))

U: ((ukáže na Danu na znamení vyvolání))

Dana: Mají dva členy.

U: ((přikývne)) Ano. Dvojčlenné věty budou mít dva členy. Dvojčlenné věty mají dva základní větné členy. (2) A jaké to budou, ty dva základní větné členy?

[David: Podmět a prísudek.]

U: Ano. Takže (n) my si zapí-, zapíšeme si do sešitů, o jaké členy se jedná. (...) 

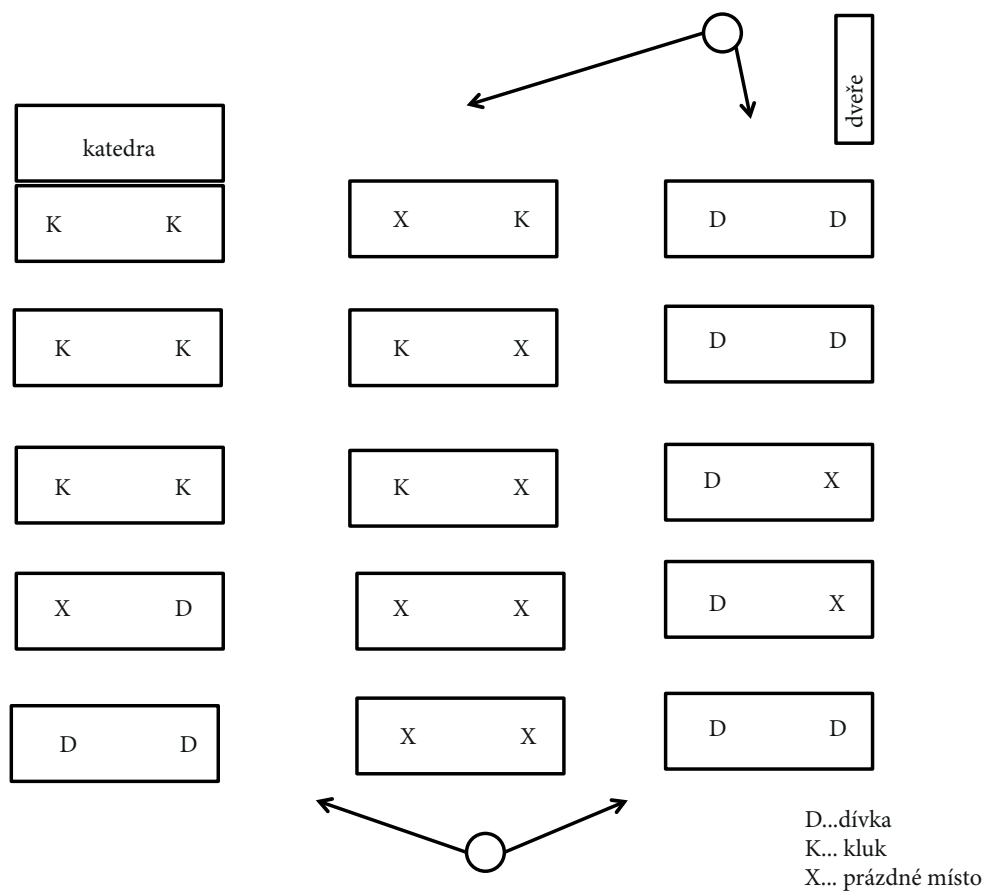

Místo D a K budou na místech, kde je to $\mathrm{z}$ videonahrávky možné rekonstruovat, doplněna konkrétní jména.

Transkripční značky upraveny podle: Lefstein, A., \& Snell, J. (2014). Better than best practice. London: Routledge. 


\section{Př́loha 5. Ukázka transkriptu videozáznamu výuky}

Výuka dějepisu studentky učitelství Karly

0-5 min.

ŽŽ: A paní učitelko, budeme se dívat na Sisi? (.) Jó, prosím, na Sisi... ((mluví jeden pres druhého, prosebným tónem))

K: [Paní učitelko, my jsme to včera (nnn)]

K Roman: ((hlásí se)) (2) Paní učitelko, já se hlásím.

((něco bouchne / zabouchání na dveře))

Ž: Dále.

U: Paní učitelka mi nedala takové instrukce. (1) Začneme nové téma.

K: Ale ona to tak myslela.

U: Určitě, pokud máte zájem, internet je toho plný. Můžete se na to podívat doma.

K: [Ale nelegálně!!

D: Co internet, my nemáme ani počítač doma.

K: ((smich))

U: No tak video.

K Roman: My nemáme doma ani zásuvku.

ŽŽ: ((smích))

U: (3) Dobře, tak co jste se dozvěděli z toho filmu?

K4: Že jí bylo 15 let.

K: 16 !

D1: [17.]

K Petr: Ŕíkali, že jí bylo 15, ale té herečce bylo 17; pak se zavraždila sama, protože její dítě se nabodlo na plot. (.) Jestli to nevíte, ale je to pravda, říkala to paní učitelka.

K: Petřée (nnn nenabaluj).

U: A něco z historických událostí?

ŽŽ: Že se oženila. ((mluví / vykřrikují preses sebe, nesrozumitelné))

D1: Vdala se teda.

ŽŽ: ((mluví/ vykřikují pres sebe))

K: Přebrala své sestře manžela.

U: No, více méně, ono se počítalo s tím, že si František Josef vybere spíš starší než mladší z obou sester.

K Roman: ((hraje si s nějakým predmětem/figurkou, interaguje s Kpr))

K Petr: Ale paní učitelko, když jemu bylo 30 a jí 15, tak proč si ji jako vzal?

U: Protože se zamiloval a protože mohl.

K: (Jako o 25 let starší?)

U: Otázka je, jak to bylo historicky: když jsme si tady pouštěli minule ten zvukový záznam, tak se tam Sisi vyjadřuje, že nebyla štastná v tom manželském vztahu, přestože to počáteční zamilování tam bylo. 
D1: Tak si ho neměla brát, ne?

K: Ona musela.

U: To je právě ta sňatková politika. (.) Tak dneska se budem bavit o královně Viktorii, trošku. To byl v podstatě současník Františka Josefa, taky nastoupila na trůn ve svých 18 letech.

ŽŽ: ((převážně poslouchají; jen D1 si šeptá se svou sousedkou a Roman s Kpr))

U: ((jde $k$ tabuli a zapisuje)) (14) No a vládla také poměrně dlouho, co se týče anglických panovníků, tak je v podstatě předčila - i když současná královna ji už dotahuje, ne-li předčí - tak nastoupila na trůn v 18 letech a vládla necelých 64 let. ((píše letopočet na tabuli)) Takže tohle je doba vlády. A narodila se tedy v kterém roce?

K Petr: Eeeehm, 19.

U: Správně. A umírá 1901, ano, na začátku roku...

K: A umřela přrirozenou smrtí?

U: Ano. (.) Můžete si spočítat, kolik jí bylo - docela dost: 83 let věku. ((píše na tabuli))

ŽŽ: ((šuškají si mezi sebou))

U: A byla vnučkou tehdy vládnoucího krále Jiř́ího -

K: A máme si to zapsat?

U: Tohlencto si zapište. Z toho mého výkladu si můžete udělat poznámky, ale to záleží na vás.

ŽŽ: ((šustí sešity, otevírají, potom si zapisují a sledují výklad))

D1: ((neustále pohazuje svými vlasy - od začátku hodiny))

U: Tedy vnučkou krále Jiřího III. a ten měl 4 syny, ale postupně se zjistilo, že ani jeden není schopen dát legitimního dědice, a tak přišla na řadu královna Viktorie, byla dcerou nejmladšího ze synů Jiřího III., její otec se jmenoval Vilém.

K: Dobyvatel!

U: Ne vlastně, omlouvám se, to byl třetí syn, její otec byl Edward. ((píše na tabuli)) Vévoda z Kentu - to si nemusíte psát - a po smrti jeho dcery Viktoriina dědečka (??!!??!!!) nastupuje na trůn její strýc.

\section{5-10 min.}

U: A ona nastupuje až tehdy, když on umírá, nastupuje v těch 18 letech. Matkou byla Viktorie, stejně jako dcera.

\section{K Oliver: $\mathrm{V}-\mathrm{i}-\mathrm{c}$ ?}

U: Vik, pište si to česky a navíc, ani by to nemohla být Victorie, protože její maminka byla Němka.

K Oliver: Aha.

U: Ona pocházela $\mathrm{z}$ takové složité dynastie (nnn). Viktorie měla takové komplikované dětství, zřejmě ani nebyla legitimní dcerou svého otce: její matka se potom více setkávala s Johnem Conroyem. ((píše na tabuli, maže a přepisuje)) 
ŽŽ: Co, jakže? Colroy?

U: Con-roy. (6) Takže dětství strávila v podstatě sama, měla německou vychovatelku, ke které byla upnutá více než k vlastní matce.

ŽŽ: To je Lonroy?

U: Con-roy. To je moje $C$. (.) Měla tedy německou vychovatelku a s matkou neměla prŕliš vřelý vztah. Ta spíš potom s tím jejím pravděpodobným milencem se snažila mít takový ovladatelný vztah k ní, protože kdyby strýc zemřel dříve, než jí bylo 18, tak Viktoriina matka mohla být ustanovena regentkou. Viktorie si toto uvědomovala a svou matku v podstatě nesnášela. Když byla potom korunována, tak se přestěhovala do Buckinghamského paláce ((piše na tabuli, maže a přepisuje)) Bu-c ... Buck...

K3: ((něco gestikuluje na Petra a usmivá se, pak mávne rukou))

U: ((napiše špatně))

K: Bu-c-k-ing-hamský se to píše.

U: ((opraví, ale stále špatně)) Ještě tam mám někde chybu? ((znovu smaže a nechá si nadiktovat od žákư správně)) (10) Takže se přestěhovala do Buckinghamského paláce. Snažila se dostat daleko od matky, aby se s ní nemusela stýkat.

K3: ((vytahuje si pod lavicí mobil))

ŽZ̆: ((zapisují si))

U: A ministerským předsedou jí bylo doporučeno, aby se brzo vdala, což se jí do toho moc nechtělo, ale nakonec $\mathrm{k}$ tomu došlo - v roce ((píše na tabuli)) 1840 a vzala si...

K3: [((šušká směrem k Petrovi)) (nnn)]

$\mathrm{U}:$...vlastního bratrance $\mathrm{z}$ matčiny strany.

K Petr: To je nezákonný.

U: Tak tehdy se s tím počítalo, tehdy by byl nezákonný pouze bratr se sestrou.

\section{0-15 min.}

U: Ty rody byly tak provázaný a - my jsme si to ř́kali vlastně už u Sisi -

K3: A třeba syn s matkou.

U: To je taky špatně, to je taky incest.

ŽZ̆: ((̌̌um, ruch))

U: A když se vrátíme do minulosti, tak dokonce u Marie Antoinetty, tam aby ji mohli popravit, tak jestli si vzpomenete, tam vykonstruovali proces a prohlásili dokonce, že měla poměr se svým 7 letým synem.

D: Kolikati?

U: No potřebovali ji popravit, tak řekli, že měla poměr se svým synem.

D: A kolik jí bylo?

K: [A to je pravda nebo ne?!]

ŽZ̆: ((̌̌um, ruch $))$

U: Matka se synem 7 letým. 
D1: A kolik bylo té matce?

U: Ehm (1) no, tak když se brala v patnácti, asi ani né třicet, plus mínus, odhadem. K3: (A za velezradu nnn?)

U: No, to byl důvod, proč ji mohly potom popravit. (2) ((piše na tabuli)) Takže, manžel Albert.

K: A kolik jim bylo?

$\mathrm{U}$ : Byl stejně starý jak ona.

K: A jí?

$\mathrm{U}: 21$.

D1: Princ Albert?

U: Princ Albert. A tam je podobná ta dynastie - Sasko-kobursko-gothajská. ((píše na tabuli)) (5)

ŽŽ: ((zapisují si v tichosti, jen někdo šušká))

U: Sasko-kobursko-gothajská. Později - aby to nevypadalo, že jsou Němci - její matka i manžel byli Němci, přestože pro svět to byla Angličanka, tak se později přejmenovala ta dynastie na Windsorskou. (.) Windsorská.

ŽŽ: ((zapisují si v tichosti, jen někdo šušká))

U: Máte opsáno? Můžu smazat?

ŽZ̆: Ano.

U: ((maže tabuli)) S matkou tedy neměla př́liš vřelý vztah, tak i k vlastním dětem měla potom trochu problém najít vztah. Její manžel, kterýji nejprve považoval za zhýralou Angličanku, ji později naučil i ten vztah k dětem. Měli spolu nakonec 9 dětí.

\section{5-20 min.}

U: K mateřství Viktorie něměla dobrý vztah (...) připadala si spíš jako kobyla nebo kráva. Její první dcera se jmenovala Viktorie.

K Petr: [((prohliží si něco pod lavicí, žrejmě mobil; směje se, šušká si s K4))]

U: A následující už byl syn Edward VII. - budoucí král.

K Petr a K4: [((usmívají se, pritakávají si, pokyvují na K3))]

D: Edward nebo Eduard?

U: Napište si to, jak chcete česky nebo anglicky. (.) Takže ř́ká se takový pojem „viktoriánská morálka“.

K: Sedmý?

U: Ano, sedmý. I když její manžel ji dost umravňoval, tak viktoriánská morálka, abyste si dovedli představit. Týkalo se to oblečení, žádné výstřihy apod., žádné hýření do noci nebo nemanželské děti, prostě prudérní.

K: A co si máme teda napsat?

U: Prudérní doba - jestli vám to něco řekne.

K: Ne.

U: Tak upjatost, přísnost (10) ((píše na tabuli)). Ještě se vrátím k té její první dceři Viktorii. 
ŽZ̆: ((zapisují si v tichosti))

U: Když ji teprve čekala, tak na ní byl spáchán první atentát. Za život jich bylo pak ještě 7 .

K: A co udělala?!

U: ((píše na tabuli)) No oni se s manželem projížděli v kočáře a ten atentátník na ně dvakrát vystřelil, ale ani jednou se netrefil. Takže ho chytli, nakonec ale nebyl ani popraven, jen skončil snad na doživotí.

K3: Jak to?

U: To rozhodl soud, královna do toho př́liš nezasahovala. Nicméně nikdo z těch atentátníků, bud' nevystřelil, nebo netrefili, nebo podobně.

KK: (hm nnn)

U: Jen jeden slabomyslný bývalý voják ji trefil (pěstí) do obličeje.

K3: A měla nějaké následky?

U: No nic zlomeného.

K3: A byl popraven?

U: Nakonec ne, měl být, ale nebyl - vzhledem k jeho slabomyslnosti.

K3: A proč ho nepopravili, když se popravovalo i za (cizoložství)?

U: Taková byla doba.

ŽŽ: ((poslouchají výklad))

U: To máš jako dnes, (...)

K: Proč?

KK: Protože můžou!

U: Protože právníci jsou bud’ špatní nebo dobří a tak. (4) Ehm, chcete si ještě napsat něco $\mathrm{k}$ tomu? 
PŘíLOHY

\section{Př́loha 6. Ukázka transkriptu rozhovoru}

Rozhovor studentky učitelství Zdeny na téma bází moci

S ... studentka učitelství Zdena

T ... tázající se

T: Dostala jste se s žáky někam na exkurzi nebo na nějaký výlet někam mimo školu?

S: Jo, byli jsme v divadle.

(5)

S: Aaaa.

T: Mě by zajímalo, jestli se proměnila ta práce se žáky a třeba i ten vztah, nebo způsob komunikace oproti tomu, když jste v té běžné tř́íě.

S: Jo, to je pravda.

T: Třeba na té exkurzi nebo na té cestě do divadla.

S: To jsme byli vlastně, do divadla jsme šli. (1) Tak to ještě nic to jsme se nebavili s děckama. A když jsem šla zpátky, tak se ke mně vlastně přidala jedna holka, která tam neměla zas až tolik kamarádů, a chtěla si vykládat se mnou no. Tak a to byli devátáci, takže jsme si vykládali, kam jde na školu a třeba si stěžovala, že ve tř́dě není zas až takovej kolektiv dobrej. A že tam není moc spokojená, až prostě odejde na stř̌ední, že doufá, že to tam bude lepší. Takže takhle nějak jsme si povídaly, no.

T: Ahm. Bylo to pro vás př́ijemné nebo nepř́ijemné třeba, lehké nebo těžké?

S: Jo, pořád jsem si říkala, že hlavně se nesmím rozkecat tak, jako třeba s kamarádkou, jo, když se mě ptala třeba, co škola a tak. Že prostě si musím tam pořád udržovat pořád ten vztah nadřízenosti nebo nadřazenosti nebo jak to mám říct. Protože (.) to nesmí sklouznout k tomu, že si budem vykládat. Protože já jsem taková, že jako docela mluvim s jakoby se staršíma nebo se sobě rovnejma docela otevřeně, že jako že jako nemám žádný témata jako tabu. Takže tam jsem si musela dávat pozor, abych jakoby udržela ten vztah.

T: A podařilo se?

S: Jo, jo.

T: Jo, to je asi taky důležité tady při tomto. Tak a řešila jste nějaké kázeňské problémy at už třeba ve třídě nebo třeba tady na té cestě do divadla?

S: Jo, to jsem řešila a řešila jsem to ve třídě. Absolutně jsem to nechápala. Eee $\mathrm{v}$ té šesté $\mathrm{v}$ té zlobivé B myslím nebo A já nevím, to je jedno. Tam byl kluk, seděl v první lavici a absolutně nic ho nezajímalo. Vůbec. Rekla jsem: „vezměte si čítanku a von si strčil tužku do pusy a koukal na mě jak péro z gauče“. Ř́kám: „co já jako mám dělat ale, že jo“. Nebo nebo vždycky prohodil, nebo se houpal na židli, mluvil sprostě, nepracoval nic. Já jsem se rozčilovala první hodinu skoro celou. 
A pak mě učetelka říká, (.) že si ho absolutně nemám všímat, že von to prostě dělá a že s děckama domluvili, že si jeho chování nebudou všímat, protože když si ho všímat, tak je to ještě horší. Dobře no a jakej má prospěch? A vona říkala, všechny domací úkoly nosí, všechny pomůcky nosí. Nepropadá, nic. Takže já jsem jakoby nechápala, že $\mathrm{v}$ hodině se chová jako hulvát a jako prospívá dost dobře.

T: Ahm.

S: Jo. (.) Tak vlastně mě bylo doporučený, abych si ho nevšímala, protože když si ho budu všímat, čím víc si ho budu všímat, tím to bude horší.

T: Pomohlo to teda?

S: Jo bylo, ta situace byla lepší. Ale jako. Haha.

T: Neměla jste z toho dobrý pocit nebo měla.

S: Jako jo ale eee prostě přesto pořád jakoby nespolupracoval no.

45 minut

S: Ale když prostě mě bylo řečeno, že ho mám ignorovat, tak jsem ho ignorovala no.

T: Nějaký takový rušivý chování, nebo něco takového jste zažila, které byste musela řešit vyloženě kázeňskými prostředky.

S: No mě přišlo, že v té zlobivé šestce no, ale učitelka mi řekla, že je to normální.

T: Haha.

S: Haha.

T: Takže ona to tak vnímala, ale vy úplně ne.

S: Ahm, ne. No.

T: Nebylo vám to moc př́ijemné, ta hladina hluku nebo.

S: No protože jsem byla zvyklá jakoby na ty hodný šestáky a myslela jsem si, že takhle je to správně. A potom když tydlencty jakoby tam eee rušili trochu, tím že třeba se furt vrtěli nebo posunovali se židlema, trochu bavili, tak mi to přišlo jako nenormální a strašně mě to vobtěžovalo a bolela mě z toho hlava. A když jsem to řekla cvičnej učitelce, tak mi řekla, že byly hodný no.

T: Ahm. No. Haha. Takže je to hodně subjektivní.

S: No.

T: Ale asi kdybyste tam měla nadále učit nebo kdyby to byla vaše třída, tak byste to asi chtěla měnit, předpokládám. Kdyby to tak pokračovalo dál. Víte, jak byste na to šla. Co byste $s$ tím mohla dělat?

S: No (1) tak samozřejmě bysem, bysme si museli stanovit nějaký ty pravidla, že jo. A (1) nevím, jestli bysem s tím mohla něco dělat. Protože jako bud' by mě ty děcka braly jako autoritu, že jo to se jako zas až tak ta autorita naučit nedá. Prostě bud’ to vyzařujete nebo vám ty děcka skáčou po hlavě. Takže to by záleželo na situaci, když by prostě mě vzali, (.) tak si myslím, tak si myslím, bysme si stanovili ta pravidla. A když by mě nevzali no, bych se musela smířit $s$ tím, že nebudou tak hodný jako ta paralelní třída. No a když by mě nevzali, tak bych se asi musela 
jakoby smírit s tím, že nejsou tak hodní jako ta paralelní třída, že je to jejich takový normální stav.

T: A čím tu autoritu lze nějak budovat. Určitě je hodně daná.

S: Jasně.

T: Něčím třeba ji lze posilovat.

S: No právě dodržováním těch pravidel jo. Jo prostě stanovili jsme si pravidla, odměny dodržovat to důsledně a tresty taky. (.) Neslevovat jo. Že třeba eee žáci přijdou nepřipravení, ačkoliv jsme byli domluvení, že se mají připravit, tak jim třeba nasázím koule, ale jakoby i když jim je potom ve finále nebudu počítat, tak jim to nebudu říkat, že jo protože oni by si řekli jé no tak prríště budeme mít koule a ona nám to zase nezapočítá.

T: Kdy se celkově cítíte pevná v kramflecích v té školní třídě.

S: Když učím němčinu.

T: Haha. Aha a proč to tak je?

S: Haha. Protože mi tam nikdo nero-

T: Haha.

S: Haha nerozumí a nikdo mě tam zatím nepřekvapil žádnou otázkou. Protože sem si prostě přišla větší odborník v té němčině než v češtině. Tam ty děcka prostě nejsou skoro na žádné úrovni. Prostě pár slovíček že a jako tam si ta si přijdu jako šéf. Kdežto v té češti-jako. Co se týče těch znalostí, tak nevím všechno, že jo. Někdo něco řekne a já si to hned neuvědomím, jestli někdo napsal nebo nenapsal že. Tak jakoby je třeba trapná chvilka jo. Kterou pak která se teda může eee vyřešit různými způsoby, můžu třeba říct, tak si to zjistěte do příště. Ale nemůžu to říkat každou hodinu dvacetkrát.

T: Haha.

S: Haha. No kdežto jakoby (.) no ta němčina je lepší.

T: Takže je to dáno tou oborovostí, že se cítíte pevnější v tom oboru. A pak se cítíte pevnější i v těch kramflecích. A není to i něčím z toho hlediska té třídy, z toho nastavení té třídy a spolupráce s tou třídou. Kromě té oborovosti, co vám pomáhá $\mathrm{k}$ tomu, abyste tu třídu zvládá. Kdy jste pevná v kramflecích nejen z hlediska toho oboru.

S: Ahm.

(9)

S: No ted' mě ještě naved'te trochu.

T: Ahm. Eee kdy máte pocit, že tu tř́du máte pod kontrolou. (.) Tu třídu jakoby ty žáky. Nejenom to učivo. Ale že vám zobou z ruky takzvaně. Jo, že jsou na vaší straně. S: Aha. Takhle.

(8)

T: Klidně nějak situace, př́íklad, jestli si vzpomenete, kdy jste měla pocit, že to funguje.

50 minut 
S: No tak jako funguje to tedy, když děláme nějaké cvičení a ty děcka jsou prostě potichu a dělaj.

T: Ahm takže když vidíte, že pracují třeba.

S: Jo jo. (2) Jakoby že je to zajímá, že s- že že. No já nějak nevím.

T: Jo. Ahm.

S: Jo?

T: Že prostě jsou zapojení, že pracují.

S: Jo.

T: Tak to znamená, že to máte $\mathrm{v}$ rukou.

S: Že prostě dělají to, co si řeknem.

T: Ahm. Jo určitě to dává smysl. Tak my jsme se tady spolu bavili o té vaší odbornosti. Vnímáte se jako odborník?

S: Určitě. Haha.

T: Haha. Bezvadné. Přesto jste naznačila trochu rozdíl mezi tou němčinou a češtinou. Takže $\mathrm{v}$ němčině se cítíte být více odborná než v té češtině.

S: Ano, ano.

T: Ahm.

S: No protože jakoby (.) ta němčina se bere vlastně, že jo třeba ji mají šestáci, sedmáci, prostě od základů úplně že jo. Takže tam si člověk přijde jako šéf. No kdežto tu češtinu maj prostě to je (1) jakoby taky ju neovládaj, ale je tam víc na co se člověk může zeptat že, a potom když člověk sám

Obsluha: Máte všechno?

S: Jo.

S: potom člověk sám neví. (1) No tak jako není to průser ale.

T: Vy jste ř́kala, že se vám třeba stane, že si nevzpomenete, jestli autor napsal nebo nenapsal dílo. Jak často se to třeba stává a co s tím. Jak třeba často se to stává a co s tím.

S: No (1). Jo (1) Tak jo protože na to jsem si vlastně naběhla sama. Že si uděláme myšlenkovou mapu jo, že uprostřed tabule bude jméno a všichni, kdo budou vědět něco o jeho životě nebo díle, tak půjdou a napíšou to na tu tabuli. Teda až po mém odsouhlasením, jestli je to dobře nebo ne. No a jeden řekl dílo, které prostě ten autor nenapsal a já jsem začla váhat, kdo to napsal. Asi to na mě poznali, že to nevím. A byla chvíli trapná situace. A zkrátka bych to vyřešila, že bych (.). Když teda fakt nevím, tak bych řekla, že (.) sss že je možné, že něco takového taky napsal, ale že si ted' nejsem jistá. Jako by prostě přiznat to, že to nevím, nedělat machra, že to vím. Protože když jim třeba řeknu, napsal to ten a ten a nějakej štoural by se doma podíval a řek si a chtěl se kouknout a viděl by, že to bylo špatně, tak si řekne: „Panebože ta je blbá, že tady té moc věřit nebudu, protože říká nepravdivý věci a tak a neví to jo a má to vědět, je to učitelka češtiny a má vejšku“. Je lepší to přiznat. A nebo to řešit do prŕššě si to zjistěte no, ale nemůže to být dvacetkrát za hodinu. 
T: Kladou často žáci takové otázky jako rýpavé nebo třeba těžké.

S: Ne.

T: Neočekávané.

S: Ne. Nenene. Nestává se to.

T: Je to spíš výjimečné, že se zeptají na něco takového.

S: Jo ale ted'ka jsme si vzpomněla. V devítce, ty téespéčka. Já jsem si je vlastně vypracovala doma a pak jsme je dělala s děckama. A byla ta- a jakoby nenapadlo mě, že děcka by se mě mohli zeptat na něco třeba, co znamená nějaké slovo. Samozřejmě sem to, jako bylo tam. Dám příklad: cosi odevzdejte v nejzazším termínu jo. A najednou všichni pracovali a jeden štoural: „Paní učitelko, co to znamená nejzazší. Ted' prostě já jsem to nečekala, ted'ka v nervech. A ted’ si říkám. Úplně jsem zapochybovala, co znamená ten nejzazší, jestli ten nejbližší nebo nejpozdější jo a ted' si ŕíkám, to je v Prčicích. Tak děcka, kdo to ví, jo řekla jsem, kdo ví, co znamená slovo nejzazší. Tak se jeden přihlásil, věděla jsem, že je to chytrolín největší jo. Jsi říkám, ten to řekne určitě dobře.

T: Haha.

S: A potom i cvičná učitelka to vodsouhlasila jo. Ale jakoby nepočítala jsem, že by se mě mohli ptát i takhle na něco. To jsem neměla připravené. A eee.

55 minut

S: Ještě jak jsem byla ve stresu, tak jsem zapochybovala jako jo.

T: Ale vyřešila jste to.

S: Ale jako vyřešilo se to, protože mě napadlo hnedka říct. Haha. Člověk to musí nějak vyřešit, nemůže říct: no, děcka, já nevím. 


\section{Příloha 7. Pokyny pro studenty učitelství k reflektivnímu deníku}

Hlavním výstupem předmětu Učitelská praxe 1 jsou vaše zápisy v pedagogickém deníku:

a) deníky povedete pravidelně po celou dobu praxe, což v prrípadě Učitelské praxe 1 činí vždy 1 den v týdnu za každý studovaný obor, celkem tedy 2 dny v týdnu (obvykle čtvrtek a pátek) po dobu 10 týdnů,

b) jednotlivé (srozumitelně označené) záznamy vkládejte do připravených odevzdáváren tak, aby je vyučující předmětu Učitelská praxe 1 - seminář měli včas $\mathrm{k}$ dispozici a mohli se připravit na výuku - viz zadání u jednotlivých odevzdáváren.

K čemu je deník dobrý? Psaní deníku pomáhá ujasňovat a třídit vaše myšlenky, pocity, postoje, přesvědčení (...), které souvisí s vaší pedagogickou praxí. Smyslem práce s deníkem je postupně se učit, jak zachycovat svoje zkušenosti tak, aby pro vás psaní bylo přínosnou činností - aby přispívalo k objevování nových souvislostí, zjištění a porozumění.

Proč považujeme psaní deníku za užitečné? Mohli bychom jmenovat řadu důvodů, ale uved’me jeden, který považujeme na počátku snad jako ten nejvýznamnější - zvyšování všímavosti k sobě, druhým a k samotným pedagogickým událostem. Aby mohl člověk totiž psát smysluplně o své praxi, je potřeba, aby se svou všímavostí začal vědomě pracovat.

Zápisy v pedagogickém deníku. Obsah zápisu v deníku se odvíjí od konkrétních činností, které během vaší praxe provádíte. Součástí každého zápisu by mělo vedle data být:

a) V jakém kontextu praxe probíhá: popište důsledně kontext, ve kterém se vaše činnosti během praxe odehrávají (především informace o žácích či tř́dě, s nimiž pracujete).

b) Co a jak dělám: popište všechny činnosti (včetně jejich časového rozsahu), jimž se ve škole věnujete.

c) Co si odnáším: napište alespoň jedu věc, kterou jste se v průběhu dne/ týdne na praxi naučili; napište jednu věc, kterou byste př́ště udělali jinak.

Během psaní se pokuste zachytit vaše:

a) Myšlenky: Co mi během praxe běželo hlavou? Co mi běží hlavou ted's odstupem, když píši deník?

b) Pocity: Jakých pocitů souvisejících s mojí praxí jsem si všiml/a?

$\mathrm{V}$ e-learningu máte $\mathrm{k}$ dispozici tři ukázky zápisů $\mathrm{z}$ pedagogických deníků studentek učitelství oboru český jazyk. Jedná se o zápisy, které vznikly po té, 
PŘíLOHY

co studentky připravily a odučily vlastní hodiny. Vaše zápisy mohou mít samozřejmě charakter odlišný, nebot' budete zaznamenávat různé činnosti, jimž jste se v průběhu vašeho pracovního dne věnovali. Ukázka slouží pouze jako informace o způsobu, jakým lze při psaní deníku uvažovat. 


\section{Př́loha 8. Ukázka z reflektivního deníku}

\section{Reflexe studentky učitelství Lenky na téma: pojetí žáka}

Dřívější pojetí žáka jakožto objektu, do kterého je potřeba "nalít“ co nejvíce informací, už dnes naštěstí neplatí. Myslím, že co se týká dějepisu ani nikdy platit nemělo, protože systematické zahrnování žáka nadměrným množstvím informací stejně nevede $\mathrm{k}$ jeho rozvoji a zvyšování vědomostí, vnímání souvislostí a oblibě předmětu. Je dobře, že dnes má učitel volnější ruku při výběru učební látky, kterou bude učit (pokud tedy látka souhlasí s ŠVP). Netvrdím, že by měl vybírat pouze kapitoly „zábavnější či ty, které se učitelům lépe učí (Velká francouzská revoluce a Napoleon se učí lépe než revoluční 20.-40. léta), může ale vynechat ty, které např́klad př́mo neovlivňují hlavní proud dějin apod. To může přispět $\mathrm{k}$ lepšímu porozumění toku dějin, prríčinám a důsledkům, souvislostem.

Jaké by tedy mělo být pojetí žáka $\mathrm{v}$ hodinách dějepisu (a samozřejmě i v jiných)? Já bych si ideálního žáka představovala jako bytost zajímající se o dění v minulosti, nevnímající dějepis jako povinný „předmět o mrtvých lidech“, hledající souvislosti mezi jednotlivými kapitolami, zvládající z př́ícin vyvodit následky, vnímající platnost určitých věcí pro současnost apod. Tato představa je značně optimistická, vím. Ale zároveň věrím, že správnou motivací, správně zvoleným prŕstupem a pečlivou př́ípravou lze alespoň částečně zapálit pro dějepis všechny žáky. A právě tím, že učitel již není tak svázaný a má volnou ruku v používání metod, pomůcek, může zapojit svou kreativitu a vytvořit zajímavé hodiny, které budou bavit. Já se o to alespoň snažím, shromažduji nejrůznější materiály, hry, hádanky a zajímavosti, které mohu žákům předat.

Myslím, že hlavní je brát žáka jako společníka, protože on je ten, který s námi hodinu utvárí. Žák není konstantní bytost, stejně jako já, podléhá náladám, vedlejším okolnostem apod. (neshody ve třídě, nastávající čtvrtletka, tělocvik či jiná akce), takže se stává, že žáci nefungují tak, jak si učitel naplánuje. Nejsou to roboti. Proto s nimi musí učitel spolupracovat, vnímat je jako sám sebe. Neříkám být s nimi kamarád a navrhnout tykání, to nepřipadá v úvahu, protože musíme zachovat rozvržení pravomocí a odpovědnosti, ale brát je jako lidi. Myslím, že důležitou vlastností učitele je empatičnost, vnímavost. Mé pojetí žáka tedy souvisí s myšlenkou, že žák, ačkoliv není na stejné úrovni s učitelem (ten má zodpovědnost, moc), stává se jeho společníkem při vyučování.

Dnes už vedeme s dětmi rozhovory, diskutujeme s nimi, a pokud se nám to nevymkne $\mathrm{z}$ ruky (př́lišná kontroverznost tématu, velmi rozlišné názory neslučující se s diskusí apod.) je potřeba pouze malého zásahu učitelské moci. Já se snažím žáky pojmout jako lidi/děti, které je potřeba trochu povzbudit k myšlení a pomoci jim objevit to, co už vědí, na co mohou svým přemýšlením přijít sami. Dějepis je pro toto jedním z nejvhodnějších předmětů, hodí se pro samostatné 
přemýšlení žáků. Ač se to může zdát na první pohled nereálné, má zkušenost mluví jinak. Cvičná paní učitelka takto pracuje již od šesté třídy a př̀i první hodině mé praxe jsem koukala s úsměvem na to, jak žáci jeden přes druhého ( $v$ šesté třídě normální) chrlí své nápady, jak by to asi mohlo být (jednalo se o látku z pravěku). Nakonec společně vyřešili problém, tedy paní učitelka jim "prozradila“ správnou cestu jejich uvažování a pokračovali další otázkou. Nebo chvíli paní učitelka vyprávěla a potom následovala další otázka, scénáře hodin nejsou vždy totožné. Líbí se mi to a tajemstvím je, že i učitel si maličko odpočine od mluvení, pokud nechá nahlas přemýšlet žáky. Jak jsem již psala v první reflexi, důležitá je volba otázek - otevřené/uzavřené, vyšší kognitivní náročnost/nižší kognitivní náročnost. Snažím se stále se zdokonalovat $\mathrm{v}$ kladení otázek a tím i v přetváření žáka posluchače v žáka společníka. 


\section{SEZNAM POUŽITÝCH TABULEK A OBRÁZKU゚}

Tabulka 1 Dílčí báze moci v pozdějších typologiích Ravena (1992, 1993)

Tabulka 2 Výzkumný vzorek

Tabulka 3 Reliabilita škál a popisná statistika pilotní verze dotazníku BMS (pilotní výsledky PdF MU, 2014)

Tabulka 4 Pohled žáků na uplatňování bází moci studentů učitelství

Tabulka 5 Porovnání bází moci u osmi zkoumaných studentů učitelství

Tabulka 6 Typologie donucovací moci

Tabulka 7 Rozšírená typologie donucovací moci

Tabulka 8 Průměrná míra žáky reflektovaného užívání forem odměňovací moci osmi studenty učitelství

Tabulka 9 Položky referenční báze moci u studentů učitelství ve výzkumném vzorku

Obrázek 1. Triáda autorita - moc-kázeň.

Obrázek 2. Metody sběru dat.

Obrázek 3. Postavení žákovské a učitelské kamery při videozáznamu výuky.

Obrázek 4. Pořadí užití metod sběru dat s typem analýz dat.

Obrázek 5. Porovnání průmèrů uplatňování bázi moci u našeho vzorku a širšího vzorku studentů PdF MU z roku 2014.

Obrázek 6. Porovnání uplatňování bází moci u zkoumaných osmi studentů učitelství.

Obrázek 7. Legitimní/donucovací moc u studentů učitelství ve vzorku.

Obrázek 8. Průměrná míra žáky reflektovaného užívání odměňovací moci studenty učitelství.

Obrázek 9. Průměr používání expertní báze moci u osmi studentů učitelství ve vzorku. 


\section{REJSTŘÍK}

A

agent sociální kontroly 38, 93, 185

analýza kvalitativních dat 58, 59, 83,

136, 166

analýza kvantitativních dat 57, 59, 160, 166

asymetrický vztah 31, 159, 167

autonomie 14, 29, 76

autonomie v plánování výuky 28

autorita 30, 31, 32, 33, 36, 37, 44, 54,

$158,159,165,167,168,176,178$

autoritativnost 30

B

báze moci $9,22,36,37,40,41,45,47$,

$54,55,56,57,58,59,60,62,63,66$,

$71,82,83,105,106,107,136,157$,

$158,160,161,162,164,165,166$,

$169,170,171,176,177,179,181$,

$182,185,187$

behaviorismus 85,182

bezmocnost 33, 46, 164

Bloomova taxonomie kognitivních cílů

112

C

concerns based model 17

cvičný učitel $19,28,36,52,56,66,68$, $69,71,72,74,75,76,77,78,79,80$, $81,99,103,105,109,115,117,119$, $136,155,165,179,180,183$

D

definice situace $27,71,72,80,147$

destruktivní moc 23, 158

didaktické cíle $24,40,79,81,82,91,92$, 95, 99, 103, 104, 108, 184

didaktická transformace obsahu 79

didaktický diskurs 24, 40, 91, 93, 101, 106, 108, 109, 135 didaktická znalost obsahu 145

dominance učitele 25,158

donucovací moc 36, 39, 40, 46, 47, 48, $54,56,58,59,60,63,66,80,82,83$, $84,85,86,90,91,92,93,94,95,96$, $101,102,103,104,106,109,111$, $114,128,130,148,159,164,165$, $176,181,182,183,185$

donucování 83, 84, 85, 89, 91, 93, 94,

$96,99,102,111,158,180$

držitelé moci $22,45,46,47,81$

E

expert $41,42,43,45,108,128,138,140$, $141,142,143,146,147,148,150$,

$151,155,156,159,162,155,156$,

$163,164,165,169,170,171,172$,

$173,176,181,182,185$

expertní moc 9, 27, 36, 40, 42, 43, 46,

$47,48,54,56,58,59,61,62,63,67$,

$71,107,108,128,132,133,136,140$,

$142,143,146,147,164,171,170$,

176,187

expertnost $43,141,146,147,149,150$,

$156,163,164,174,176,182$

extenzívní pamět’ 173

F

fáze přežití $17,18,19,104,181,182$

formální vzdělání 68

G

gradace donucovací moci $87,88,89$, 92, 103

gradace odměňovací moci 106

H

Hawthornský efekt 180

hegemonie 24

hranice 28, 29, 80, 82, 166 
Ch

charismatická moc 44, 158

I

idealizace 157

identifikaci s učitelem $45,160,161$

identita $11,12,13,14,17,19,20,21,27$, 44, 138, 164, 157 168, 170, 176, 181

interakční řád 184

implicitní pravidla $72,74,80,121,122$,

$126,130,131,185$

informační moc 45, 46, 47

integrativní moc 23, 158

interpersonální chování 16, 27, 40

IRF komunikační struktura $83,85,86$, $87,88,90,92,100,103,109,110$, $114,115,130,135$

K

kamarádský vztah 163, 167

kariérní rozhodování 12,13

kázeň $30,31,32,33,40,54,92,101$, $103,154,176,181,183$

klima tř́́dy $13,25,40,82,103,158,183$

kolonizace $25,129,154$

komunikace 9, 16, 31, 44, 52, 53, 74, $85,87,109,111,113,114,130,146$, $159,163,164,165,166,168,173$, 176, 187

konativní cyklus 173

konformita $38,44,66,95,96,158$

konsilience 158

konstruktivismus 182

kontrakty $25,44,158$

konverzační situace 167

kritický druhý 18, 19, 69

kritické události 18, 19

křížení diskursů 93

kurikulum 25, 26, 29, 30, 186

L

legitimní a donucovací moc 57, 105, $106,148,181$ legitimní/donucovací $56,61,62,63,64$, $65,67,80,87,96,107,1352,182$ legitimní moc 9, 29, 35, 36, 37, 38, 41, $45,46,56,66,67,68,69,70,71,72$, $73,75,76,77,78,79,80,81,83,84$, $105,116,117,120,127,136,137$, $164,165,179,181,183,187$ legitimní moc cvičného učitele 72,77 , 78

M

manipulace 40 metafora divadla 184 $\operatorname{moc} 9,19,23,29,35,37,41,45,46,54$, $74,75,77,80,81,85,107,108,120$, $127,138,140,142,143,146,147$, $148,150,156,158,159,160,162$, $163,164,165,166,169,176,179$, $181,183,185,187$

mocenská konstelace 25, 31, 34, 81 mocenské uspořádání $26,27,28,29,34$, $35,52,59,68,138,183,184$ mocenský vztah $30,31,33,35,48,115$, $137,138,148,155$

model vývojových fází učitele 17 motivace žáků 135, 159, 163, 165, 174, 175

$\mathbf{N}$

nekázeň $26,30,40,87,101,102$ neočekávané situace $36,98,181$ nestabilita 12

O

období hájení 27

odměna $25,40,41,42,47,63,96,102$, $105,106,108,109,110,111,112$, $113,115,116,118,119,122,126$, $127,128,129,130,131,132,135$, $136,137,163,165,179,181,182$ 
odměňovací moc $36,41,42,46,48,54$, $56,58,59,61,62,63,65,66,85,105$, $106,107,108,109,114,127,129$, $135,136,164,165,176,182,185$ odměňování 41, 105, 108, 109, 137 otevřené systémy 14

P

pacifikační strategie 39

pasivní rezistence $26,89,90$

pedagogický populismus 165

pedagogické myšlení 182

performativita 184

persuaze 83

pojetí výuky 176, 177, 182

polostrukturovaný rozhovor 51, 53, 179

pozitivní a negativní sankce 38, 92

pozorování výuky studentů učitelství

$51,172,179$

pravidla $45,51,53,72,74,94,96,118$,

$119,120,121,128,130,137,159,163$, 168

pravidla třídy $71,72,94$

pregraduální příprava učitelů $9,11,13$, 185

prekoncepty 26, 92

produktivní moc 23,158

profesní identita $11,13,21,181$

profesní růst $14,177,178$

přijetí závazku 11, 13, 19

\section{R}

raný idealismus 19

referenční moc $9,36,42,54,56,58,59$,

$61,62,63,64,81,132,150,158,160$,

$164,165,181$

referenční a expertní moc 114, 164, 176

referenční a odměňovací moc 107, 136

referenční figura 45, 163, 164, 165, 166 referenční moc $9,19,36,41,42,44,45$, $46,47,48,54,56,58,59,63,64,66$, $71,81,107,117,132,136,150,157$, $158,159,160,161,162,163,164$, $165,166,170,171,176,177,182$, 185,187

reflektivní deník 51, 54, 57 regulace emocí 174 regulativní diskurs $24,84,91,92,93$, 95, 101, 103, 106, 108, 109, 135 relační moc 54, 158, 159 rezignace na donucovací moc 87,92 , 98, 103 rezignace na expertnost 164 rituál moci $9,183,184,185,186,187$ role učitele $8,9,17,19,20,24,26,27$, $28,30,35,36,37,38,42,67,69,70$, $74,75,77,79,8187,95,120,157$, $166,167,169,170,178,181,182$, 187 rozhodnutí stát se učitelem 13, 19, 62 $\check{\mathbf{R}}$ řízení třídy $8,40,54,72,79,81,84,87$, $92,93,95,101,103,181,186$

\section{S}

sebenaplňující se očekávání 108, 132 sebe-ochraňující fáze 16 sebepoznání 20 self $16,17,159,173,175,181$ smíšený výzkum 48, 56, 58, 166 sociální role $66,180,181,184$ sounáležitost 45,160 stávání se učitelem 20,74 strukturální limitace 28 styl výuky učitele 160 subjektivní spokojenost 13 subjektivní vývojový status 12 suportivní atmosféra ve třídě 170,173 symbolické násilí 24 systémové pojetí $14,15,183$ 
$\check{\mathbf{S}}$

šok z reality 14,18

T

Teacher Power Use Scale 54, 60, 106, 107, 161

techniky změny chování $30,113,137$

tenze 14, 20, 21

teorie regulace 174

transakční analýza 83

trest $25,39,40,41,47,82,83,84,94$,

$95,96,97,98,99,101,102,103,129$

trestání 23, 39, 40, 63, 93, 179, 182

triangulace 49

tvrdé a měkké báze moci 47, 157

$\mathrm{U}$

učitelova znalost obsahu 24

učitelská praxe $8,16,48,49,132,163$, 169,187

únikové strategie $25,27,147$

ustavování moci 11, 24, 26, 49, 157, 163

V

veterans 170

videostudie 51

vnitřní identifikace s rolí učitele 20 vynořující se dospělost $8,11,12,13,14$,

70,181

vynořující se identita učitele 14

vývoj ega 16

vývoj identity $11,20,21,38$

vývoj osobnosti 13

vývoj učitele $11,14,15,16,17,18,19$, $20,21,37,197,181,236$

vývoj kognitivních procesů 16

vývoj kompetentnosti 17

vztah student učitelství - cvičný učitel

15

Z

začínající učitel $11,14,15,16,17,18$, $19,20,21,24,26,27,28,37,40,49$, $45,73,87,92,103,170,176,179$, $180,181,182,187$

zaměření se na sebe 12

zdroj legitimity 37, 66

zpětná vazba $43,45,56,108,114,130$,

$140,146,147,163,173,174,175$

$\check{\mathbf{Z}}$

žákovský registr 74, 121 


\section{INFORMACE O AUTORECH}

Doc. Mgr. et Mgr. Kateřina Vlčková, Ph.D.

Působí na Katedře pedagogiky a na Institutu výzkumu školního vzdělávání Pedagogické fakulty Masarykovy univerzity (PdF MU) v Brně. Vyučuje metodologii pedagogického výzkumu a evropskou vzdělávací politiku. Zabývá se výzkumem učení a vyučování. Je autorkou monografií o strategiích učení.

\section{Mgr. Kateřina Lojdová, Ph.D.}

Pracuje jako odborná asistentka na Katedře pedagogiky PdF MU. Vyučuje teorii výchovy, reflektivní semináře k praxím studentů učitelství a pedagogickou komunikaci. Odborně se zabývá kvalitativním výzkumem a sociálními jevy a procesy ve výchově a vzdělávání. Vydala monografii Zvol si mou cestu! Edukační aktivity subkultury freeganů ve veřejném prostoru.

\section{PhDr. Josef Lukas, Ph.D.}

Působí jako odborný asistent Katedry psychologie PdF MU a zároveň externě vyučuje psychologii na Katedře psychologie Fakulty sociálních studií a na Př́rodovědecké fakultě MU. K jeho profesním zájmům patří komunikace a interakce učitele a žáka, profesní a osobnostní vývoj učitele, identita učitele, analýza internetových stránek škol, diagnostika sociálního prostředí školy a evaluace škol či psychologie vedení a vůdcovství. Je spoluautorem monografie Psychologie vůdcovství.

\section{Mgr. et Mgr. Jan Mareš, Ph.D.}

Je vedoucím Katedry psychologie PdF MU a výzkumným pracovníkem Institutu výzkumu dětí, mládeže a rodiny Fakulty sociálních studií MU. Vyučuje pedagogickou a sociální psychologii a diagnostiku. Výzkumně se zabývá adolescencí, klimatem školy či otázkami vzdělávání učitelů. Je autorem diagnostických nástrojů a evaluačních nástrojů pro školy.

\section{Mgr. et Mgr. Bc. Zuzana Šalamounová, Ph.D.}

Působí na Ústavu pedagogických věd Filozofické fakulty MU. Vyučuje kurzy kvalitativního výzkumu, školní pedagogiky a didaktiky. Výzkumně se zabývá problematikou školního jazyka a komunikace ve školní třídě. Je autorkou monografie Socializace do školního jazyka a spoluautorkou monografie Komunikace ve školní třídè. 


\section{Mgr. Tomáš Kohoutek, Ph.D.}

Působí na Katedře psychologie PdF MU. Vyučuje pedagogicko-psychologickou diagnostiku, vývojovou psychologii, psychologii duševního vývoje a psychopatologii. Zabývá se psychometrikou, diagnostikou a strategiemi zvládání zátěže. Je spoluautorem Psychologie katastrofické události a evaluačních nástrojů pro školy (Anket pro žáky, rodiče a učitele).

\section{Mgr. Jarmila Bradová}

Působí na Katedře pedagogiky PdF MU. Vyučuje didaktiku, teorii a metodiku výchovy a reflektivní semináře k praxím. Zabývá se výzkumem komunikace ve třídě. Její studie o zasedacím pořádku ve třídě získala cenu České asociace pedagogického výzkumu.

\section{Mgr. Stanislav Ježek, Ph.D.}

Je výzkumným pracovníkem Katedry psychologie a Institutu výzkumu dětí, mládeže a rodiny Fakulty sociálních studií MU. Vyučuje metodologii výzkumu, statistiku a psychodiagnostiku. Zabývá se psychosociálním klimatem školy, kvalitou života, dospíváním, autonomií a konstrukcí diagnostických nástrojů. Vydal monografie o psychosociálním klimatu školy. 


\section{Z POSLUCHÁRNY ZA KATEDRU}

Mocenské vztahy ve výuce studentů učitelství

Kateřina Vlčková, Kateřina Lojdová, Josef Lukas, Jan Mareš, Zuzana Šalamounová, Tomáš Kohoutek, Jarmila Bradová, Stanislav Ježek

Jazyková korektura: Bc. Pavla Gerlingerová, PhDr. Mgr. Jana Chlápková

Vydala Masarykova univerzita v roce 2015

1. vydání, 2015

Náklad 350 výtisků

Sazba a tisk Metoda spol. s r.o., Hluboká 14, 63900 Brno

ISBN 978-80-210-8096-6 